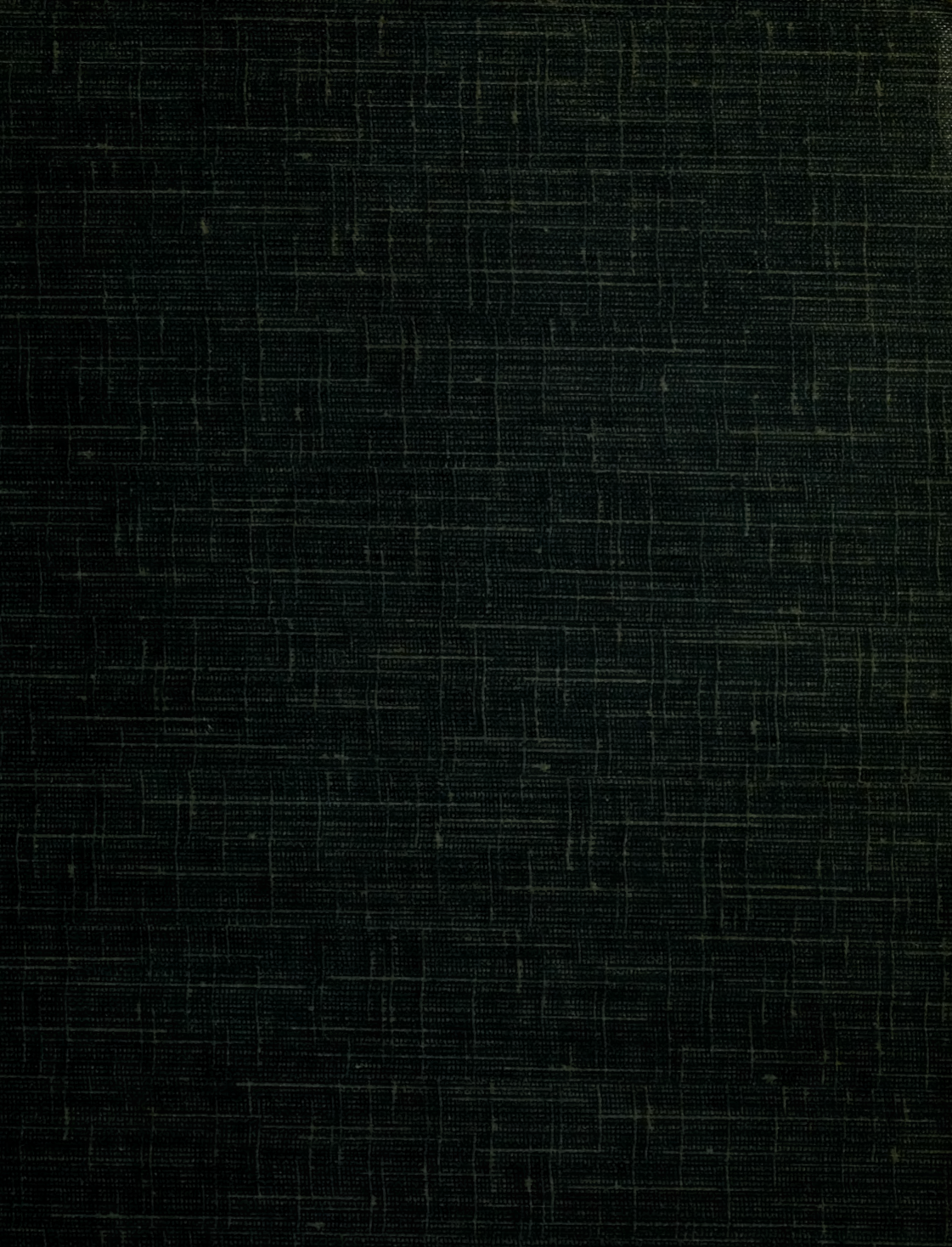




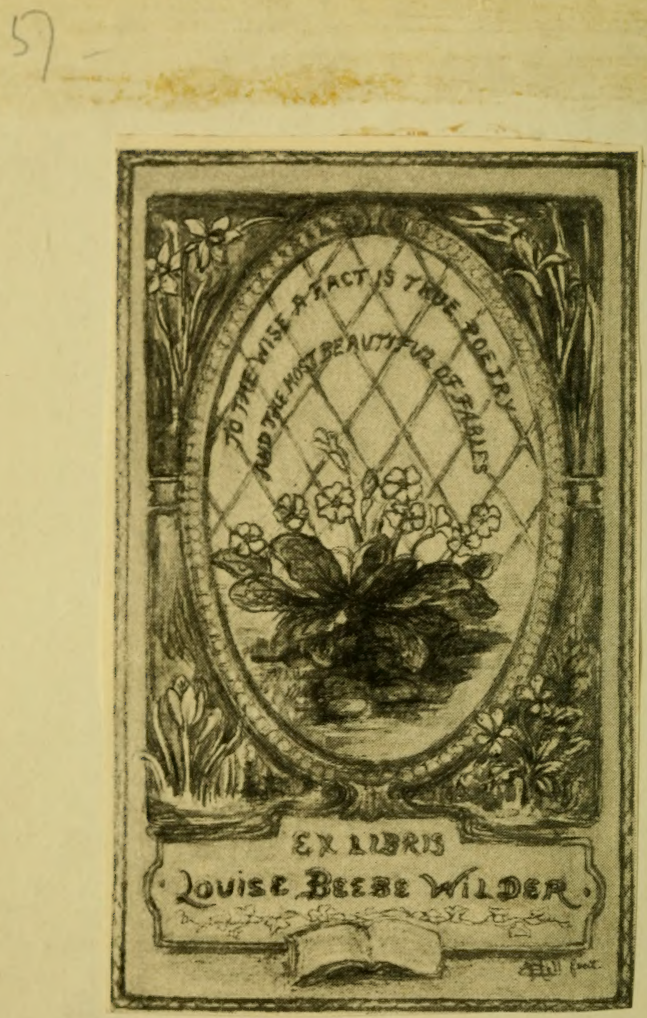






\section{Popular Names}

OF

\section{Flowers, Fruits, \&c.,}

As used in the County of Somerset and the adjacent parts of Devon, Dorset and Wilts.

Compiled by $\mathfrak{A}$. I. Macmillan.

Reprinted from the Somerset County Herald.

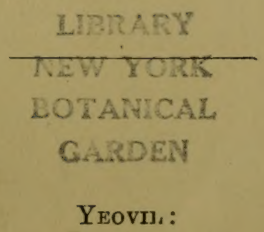

Western Gazette \&c. Co., Ltd.

1922. 
- $M_{32}$ 


\section{PREFACE.}

A few months ago the following question appeared in the Notes and Queries Column of the Somerset County Herald:-

LOCAL FLOWER NAMES are often very apt and expressive. I recently heard the Michaelmas Daisy called "Farewell Summer." Can any reader of the Notes and Queries Column kindly tell me whether a collection of local flower names has been published in Somerset? -L.N.

I hope it is no breach of confidence to say that the gentleman who made this enquiry is one who takes very great interest in all matters relating to the county of Somerset. I do not pretend to know what was his purpose in asking this question, but I have a suspicion that one of his objects, at any rate, was to elicit and to emphasise the fact that no such list of flower names has ever been published for this county, and possibly he had a faint hope that by thus calling attention to the matter in the columns of this paper, somebody might be stimulated to take up the work. If he had any such hope the querist can congratulate himself upon having attained his object, in so far as the list of local names of flowers which I have compiled and of which I print the first instalment to-day can be regarded as carrying out his ideas. In spite of its many shortcomings (of which I am only too conscious), I believe this list is by far the most complete of its kind that has ever been attempted in this part of England, and its compilation is a direct result of the insertion of the question quoted above.

It is only fair to myself and to others that I should confess at once that my own knowledge of these local names as well as of botany, etymology, and every other subject that is necessary for the intelligent compiling of such a list is very limited, and in undertaking this work I have been almost entirely dependent upon the help of others, the total number of persons who have assisted in compiling this list amounting to many hundreds, both old and young. The foundation of the list was a very fine collection of replies to popular competitions received at different times over a period of $\mathbf{1 2}$ or 15 years 
from readers of the four papers owned by the proprietors of the Somerset County Herald, in which prizes were offered for the best lists of the mot interesting local names of flowers used in the district in which the competitor resided. All the lists received in each of these competitions were carefully pigeon-holed, but no attempt was made to use them in any way until the question quoted above induced me to start get. ting the many hundreds of names they contained into something like order. An appeal for help and the offer of further prizes through the columns of the Company's four newspapers in November last brought in some hundreds of new names to be added to the list, and at the same time made it very evident that there were hundreds of other local names still to be obtai red if one could only find the means of getting them. I thereupon approached a large number of schoolmasters and mistresses in different parts of the county with a view to securing their interest and help in collecting such local names from their scholars, and although by far the greater part of those to whom I appealed ignored my letters entirely, a number of masters and mistresses were kind enough to bring my request before their boys and girls, from many of whom I received exceedingly interesting and useful lists of names. Unfortunately my helpers, both old and young alike, were not always absolutely reliable in the information they gave, and $\mathrm{my}$ own knowledge of the plants and of their local names-particularly those in distant parts of the county to which I was a stranger-has in many cases not been sufficient for me to be quite sure of my ground in including some of these local names in $\mathrm{my}$ list and in attaching to them the scientific names of the plants which I believe were intended by the senders. I have thought it well, however, after exercising every possible care, to include for the present a number of names which I cannot myself guarantee, but which are given upon the authority of correspondents in the districts which I have named; and $I$ hope that many readers of this paper who are interested in the subject may be able to confirm-or, if necessary, to correct-some of these names, with regard to which my present information is not as complete or as satisfactory as I would wish. Several of the best botanists in the county have very kindly promised to look through proofs of mylst before it appears in the paper, and I have no doubt that their greater knowledge of the subject and the fact that they are familiar with the local names used in the different parts of the county in which they reside will not only add considerably to the length of my original list, but will save me from making any serious mit takes into which without their assistance I might possibly have fallen. 
Some c:itics may enmplain that my list inciudes many names which wre of a general rather than of a locel eharacter. My answer is that in compiling this li:t I have tried io serve a double purpose-not simply to collect and to preserve some of the most interesting of our purely Somerset folk-names, but also to assist as far as I am able the proverbial " $\operatorname{man}$ in the street " and the boys and girls in our village schools to learn the correct names of many of the flowers in which they are interested, but which at present are only known to them under some popular name either local or general. As a rule I have included in this list only names which have acquired a certain local interest through having been sent me by correspondents living in the district I am attempting to cover, or which I have obtained from local glossaries. I know that our larger dictionaries and botanical works contain many hundreds of popular names of flowers which are in more or less general use, and of old English names which are now more or less obsolete, which would have enormously increased the length of $m y$ list if $I$ had thought fit to include th $\mathrm{m}$, but broadly speaking I have left all such names alone, except in those cases in which local readers have apparently been familiar with - and sufficiently interested in - any such name to insert it in the lists they have sent me.

I had several reasons for including a number of names from the adjacent parts of Devon, Dorset, and Wilts. In the first p!ace I had collected some hundreds of names from readers living in those border districts, and thought it a pity not to make any use of them, especially having regard to the fact that some of them had never before been published, and in many cases they supplement or throw additional light upon the names used in Somerset. Further, the best and most useful lists of local flower names that I could trace as having been published in this part of England were the Rev. Hilderic Friend's "Devonshire Plant Names" and those given in the "Glossary of Wiltshire Woids" by Mr. G. E. Dartnell and the Rev. E. H. Goddard. Both these works have been a great help to me in preparing my own list. Mr. Edward Vivian, of Trowbridge, who lives within two or three miles of the Somerset border, kindly sent me a carefully-compiled list of about 500 names used in that district, a large percentage of them being in use over a fairly wide area extending well into the county of Somerset. Residents in the reighbourhood of Frome and throughout East Somerset generally would probably find that they had far more names in common with Mr. Vivian than with any list of equal length which might be compiled at, say, Wellington or Dulverton, which, although in this county, would have much more in common with the names of East Devon. 
I have myself lived for over 35 years within a mile of the Dorset border, but more than 50 miles away from Minehead or Portishead in my own county, and the names given by the Rev. Wm. Barnes and Mr. J. C. Mansell-Pleydell and others in Dorset lists are much more familiar to me and to many other people in South and East Somerset than many of the names given by Mr. F. T. Elworthy in his masterly "Word-book of West Somerset."

Readers who are in any way interested in these local flower names are strongly cdvised to cut out the columns week by week as they appear in the paper and to preserve them for future reference. The Glossary which commences this week will extend over several months, and as soon as it is complete $I$ hope to publish an Index to it in which all the scientific names quoted in the Glossary will be arranged in alphabetical order. Opposite each scientific name will be given the whole of the local names for that particular plant which have appeared in the Glossary, and this arrangement should prove both interesting and helpful to the learner and the expert alike. For instance, a reader knows a flower by no other name than "Adam and Eve." A reference to the Glossary will show him that this name is given to five different plants, amongst them being Arum maculatum and Orchis mascula. If he turns to the Index he will find under the heading Arum maculatum probably at least 50 or 60 other local names for this one plant, and by going back to as many as he pleases of these other local names in the Glossary he will learn much more about the plant to which they are applied. Similarly under the heading Orchis mascula he would probably find a dozen local names given for this plant, and by referring to these names in the Glossary he would acquire additional information. Acting upon the advice of several of the best known botanists in the county, I have adopted as my standard for the scientific names of our British wild flowers the latest (10th) edition of the London Catalogue of British Plants (1908), which I have followed as closely as possible.

Before the type is distributed a limited number of reprints will be made, and as soon as publication is complete in the columns of the newspaper, the Proprietors, I hope, will issue the full Glossary and Index in book form at a price not exceeding $5 \mathrm{~s}$, and possibly less. May I add that in any case I myself shall not profit by it in any way. The work I have done in this connection has been a labour of love for which I have not received and do not wish to receive any reward whatever beyond the satisfaction of having done this little for my native county in the hope of interesting other Somerset people in its beautiful flowers and in its folk-names for them. So far as the Company are concerned, the cost of collecting and publishing this vast amount of material 
will greatly exced any sum they may hope to receive from the sale of the book, and I trust, therefore, that any reader who is able to add in any way to the completeness or correctness of this list will not refrain from doing so through fear that by so doing he may be contributing to the Proprietors' or to my own gain.

"For Somerset's sake "I appeal to readers who are interested in this subject to be good enough to send me from time to time additions, corrections, or suggestions which may occur to them. The list I am hoping to print will be very far from being a perfect list, and I claim for it nothing more than that it is a contribution towards a more worthy Glossary for our county, which I hope may some day be compiled by an abler man, with a wider knowledge of the subject and other sources of information besides those upon which I have been able to draw. But Somerset is a large county, and (as my list shows) these local names differ very widely in different parts of it, and it is impossible for any one man to compile a complete list without generous help from correspondents in every corner in the county. I claim to have made my contribution towards the formation of a Somerset Glossary of plant names, and I hope that many of our readers who take any interest in the subject - and who amongst them.does not? -will assist in the work by making such additions as they may be able.

MAY 21st, 1921.

A. S. MLACHILLAN. 


\section{POPULAR NAMES}

\section{。 \\ FLOWERS, FRUITS, \&c.,}

As used in the County of Sumerset and the adjacent parls of Devon, Dorsst and Wilts.

I AARON's BEARd. (1) The large flowered St. John's Wort, Hypericum calycinum; so named from the bundles of stamens, which have a very beas'd-like appearance. Commonly calle! "Ro e of Shar n."

(2) A white-flowered plant of Chinese origin, Saxifraga carmentosa, largely grown in the West of England in pots, and known by a variety of names, including Spider-plant and Strawberry plant, from the way in which the young plants hang on their runners over the sides of the flower pot. Othe" lccal n: mes are Moth $\mathrm{r}$ ( $\mathrm{f}$ ' $\mathrm{h}$ ' u ands, Greeping Sailo, Old Ma i's B ard, and Wandering Jew

(3) In N.W. Wilts the heads of the Crow Garlic Allium rineale, with the stiff young leaves growing out of the bulbils.

(4) A correspondent at Compton (between Yeovil and Sherborne) informs me that the name is given in that district to the Monkshood, Aconitum Napellus.

Aaron's Flannel. Great Mulleir, Verbascum Thapsus (Melplash, Dorset).

AARON's PRIDE. London Pride, Saxifraga umbrosa. I have this name only from the Headmaster o 'Sexey's Sch o', who received it from a Clevedon lad.

AARoN's RoD. Fairly general name for (1) Great Mullein, Verbascum Thapsus

(2) Common Golden Rod, Solidago Virgaurea.

(3) The various garden varieties of Tritoma or Iniphofia, more commonly known as Red Hot Poker or Flame flower.

(4) Severd correspondents give the name as being applied to Common Agrimony, Agrimonia Eupatoria.

ABBEY. A Somerset name for the Great White Poplar, Populus alba. A corruption of the Dutch name Abeel, which was introduced with the tree from Holland in Evelyn's time. above.

Abele ol Able Tree. The White Poplar as 
ABRICock. A very common Somerset form of Apricot, Armeniaca vulgaris. Gerard (1636) said "The fruit is named in England Abrecoke, Aprecock, and Aprecox." Miller in his Kalendar 1733, calls it AprICOCK.

ACorn 'Tree. A number of correspondents at Paulton give $m_{3}$ this as the local name for the Oak, Quercus Robur.

ADAM AND EvE. A fairly general nams for (1) One of our commonest English orchises, the Early Puiple, Orchis mascula; and

(2) also for the Spotted Orchis, Orchis maculata. According to Craven the name is given to the two tubers of the plant, which to the fanciful were held, singly, to resemble the human figure, and, together, to suggest the first parents of our race.

(3) The name is also frequently applied to the Wild Arum or Ouckoo pint, Arum maculatum.

(4) Mr. Edward Vivian, of Trowbidge, and a correspondent at Ilton inform me that in those districts the name is given to the Monkshood, Aconitum Napellus.

(5) My Ilton correspondent says the name is also given to the Common Lungwort, $P u l$ monaria officinalis.

Adax AND Eve IN THE Bower. A correspondent at Winsham gives me this as one of the local names for the Dead Nettle.

Adar's Fuannes. Great Iullein, Verbascum Thapsus.

ADAM's NEEDLE. (1) The popular nams of the genus $Y$ ucca, particularly $Y$. filamentosa, which is sometimes called ADAM's NeEdLe AND THREAD on account of the leaves bearing threadlike fibres on their margins.

(2) Shepherd's Needle or Venus' Comb, Scandix Pecten-Veneris.

ADDER's FLowers. Several correspondents, mostly in the Chard and East Devon districts, give this as a local name for

(1) The Eariy Purple Orchis, Orchis mascula.

(2) Spotted Orchis, Orchis maculata.

(3) Wild Hyacinth or Bluebell, Scilla nonscripta.

(4) Rad Campion, Lychnis dioica.

ADDER's FOoD. A name given to the red berries of a number of plints, which ate poisonous or supposed to be so, parti :ularly to those of the Wild Arum, the Iris, Bryory, \&c. The word Adder in this and most of the following names has nothing to oo with snakes nd reptiles at all. It is neither more nor less than the AngloSaxon word attor, which me'ns " poison." Attorberries, meaning Poison-benries (the very name is still ased in Sussex) was changed fist to Adder Berries, then to Adder's Food or Adder's Meat, and finally in many cases to Snake's Food. 
ADDER's GRAss. Early Purple Orchis, Orchis mascula.

ADDER's MEAT. In addition to being commonly applied to the red beries mentioned under ADDER's FOoD, thi; is a very general name for

(1) The Greater S! itchwort, Stellaria Holostea; Dr. Downes informs me that in Cornwall children think they are sure to be bitten by an adder if they gather the Stitchwoit.

(2) Also for the Wild Arum, Arum maculatum ;

(3) Mi. Wevell, of Stogursey, tells me in that disirict the name is applied to the IVild Parsley. (Probably Anthriscus sylvestris or Caucalis Anthriscus.)

ADDER's Mouths. (1) Several correspondents give this as a local name for the Wild Blue (or Stinking) Iris, Iris fatidissima.

(2) A correspondent at Chard gives this as a local name for the Early Purple Orchis, Orchis mascula.

ADDER's ToNGuE. (1) The general Euglish name for the fern Ophioglossum vulgatum, so called "Because out of every leaf it sendeth forth a kind of pestal, like unto an adder's tongue; it cureth [on the doctrine of signatures] the biting of serpents." Coles, Adam in Eden, p. 558. The scientific name Ophioglossum is a compound of two Greek words meaning "Serpent's tongue."

(2) In West Somerset the name is frequently applied to the Wild Arum or Cuckoo-pint, Arum maculatum. I also have this name fo om a currespondent at Uplyme

(3) In Devon and parts of Dorset the Early Purple Orehis, Orchis mascula.

(4) The common Hart's Tongue frn, Phyllitis Scolopendrium.

(5) In South-West Wilts the Twayblade, Listera ovata.

(6) The Rev. Hilderic Friend says in Devonshire the name is given to the Arrowhead, Sagittaria sagittifolia, and that the old people say that a cupful of tea every day made of nine leaves of this plant to a pint of water boiled together is a good strengthening medicine if taken in spring and autumn.

ADDERwORT. The Snakeweed or Bistort, Polygonum Bistorta, from its writhed roots.

AERoplanes. The winged fruit of the Sycamore, Acer Pseudo-platanus. I have had this name sent me by school boys from a great many different parts of Somerset, and I regard it as a rather remarkable illustration of the ready way in which they apply up-to-date and appropriate names to natural objects.

AFTER Gruss. The grass which grows after the hay is gone. It is not a second crop to be mown, but to be fed.-F. T. Elworthy.

Commonly called EE-GRAss in East Somerset and Wilts. 
AGgermony. A West Somerset comuption of

"Agrimony," Agrimonia Eupatoria.

AgLeaf. Great Mullein, Verbascum Thapsus.

AGLET. The haw or fruit of the Hawthorn Cratregus_monogyna.

The catkins of the Hazel, Corylus Avellana, are called Aglets in Gerard's Herbal.

Ars. The beard of barley when broken off from the grain. The individual husks of any corn are also called Ails. The term is only applied to the separated spear or husk-never when still attached to the grain.-F. T. ELWORTHY. Hollyband has "the EILES or beard upon the eare of corne."

ALDERDRAUGHT or Alderdrots. Correspondents at Horton and South Petherton give this as local name of the Cow-parsnip, Heracleum. Sphondylium, more commonly called Eltrot or Hogweed.

Ale-Cost or Alecoast. An old English name for the common Costmary, Tanacetum vulgare or Balsamita. The name was given because the plant was formerly put into ale.

ALE-Hoof. A fairly general name for the Ground Ivy, Nepeta hederacea, given to the plant because it was formerly used in making ale.

ALEXANDERS or ALISANDERs. The Horse Parsley, Smyrnium Olusatrum. It has been suggested that the name "Alexanders" is probably due to the fact that one of the earlier names of the plant was "Parsley of Macedon," which was Alexander's country. Another suggestion is that it is a corruption of its scientific name Olusatrum, which is Latin for "black pot herb." The plant was formerly cultivated instead of celery.

Alison or ALrsson. An English form of Alyssum. The name is said to be derived from two Greek words meaning " no dog madness," because the ancients used the plant as a remedy for the bite of a mad dog.

ALI-BONES. Gieater Stitchwort, Stellaria Holostea. "All-bones" is a free and easy translation of the scientifis name Holostea, which is taken from the Greek. The name is given to the Stitchwort on account of the brittleness of its stalks. In Cheslire it is called Break-bones, from theis snapping off at the joints.

AllewUIA. The Wood Sorrel, Oxalis Acetosella. From its blossoming between Easter and Whitsuntide, the season at which the Psalms were sung which end with that word, viz those from the 113th to the 117th inclusive. It bears the same name in German, French, Italian, and Spanish for the same reason. The name is met with in 15th century manuscripts in the Bodleian. 
Alter. The Alder tree, Alnus rotundifolia, is nearly always so called in WVest Somerset. Dr. Prior says this local form is the original and more proper form of the name, which comes from the Anglo-Saxon; the "d" has been inserted for euphony.

ALI-Good. Hercury Goosefoot, Chenopodium Bonus-Henricus. An old name given to the "Gool King Henry" Goosefoot (sometimes called "English ilercury") on account of its excellent qualities as a remedy and an esculent. Its Dutch, Germon, and French names have the same meaning Sie Good KING HENRY.

ALL-IIEAi. (1) Great Wild (or Cat's) Valerian; Valeriana officinalis. It owes its popular name to the fact that until comparatively recent years country people commonly used the leaves as an application to wounds.

(2) Perhaps the name ALL-HEAL or C'Lowr's ALL-HEAL is more generally given to the Marsh Woundwort, Stachys palustris, which Gerarde praised as healing "grievous and mortal wounds." He says he derived his knowledge of its powers from a clown, who cured a wound with it in a week, which wo ld have sequired forty days with balsam itself ; hence he called the plant "Clown's All-heal " or "Clown's Woundwort."

(3) In old name for the Mistletoe, Viscum album. Dr. Downes informs me that in the neighbourhood of Ilminster the Mistletoe is sometimes called "Churchman's Greeting," and he raises the question whether the old name for the Mistletoe was not therefcre ALL HAIr rather than ALL HEAL.

(4) The name is sometimes given to the Common Solf-heal, Prunella vulgaris, which is still known also by some (f its old names of Carpenter's Herb, Sicklewort, Hookweed, \&c., which allude to its uses as a vulnerary; and many cases are recorded by old herbalists in which wounds inflicted by sickles, scythes, and other sharp instruments were healed by its use.

(5) A correspondent at Stoke-under-Ham gives me this as a local name for the Dead Nettle, Lamium.

ALL Rot. Mr. H. A. Bending, of Shoscombe (near Bath) informs me that this is one of the names given in that dist ict to the Cow Parsnip, Heracleum Sphondylium, in other parts of Somerset called Eltrot (of which the above name is a corruption) or Limperserimp.

ALL SEED. A name given to a variety of small weeds bearing a large number of seeds. Probably most commonly given to

(1) The Four leaver All-seed, Polycarpon tetraphyllum, of which the scientific name comes from the Greek and means "Four-leaved manyfruit." 
(2) The Thyme-leaved Flax-seed, Radiola Linoides.

(3) A plant that formerly bore this name was the Common Knct-grass, Polygonum aviculare.

(4) The Many-seeded Goosefoot, Chenopodium polyspermum.

Alsike Clover. Sivedish Clover, Trifolium hybridum. So called from its growing abundantly in the parish of Alsike, near Upsala, in Sweden.

Altrot. Cow-parsnip, or Hogweed, Heracleum Sphondylium. Perhaps more commonly called Eltrot in East Somerset, and Limperscrimp in West Somerset.

AMERICAN CREEPEP. Tropaeolum peregrinum. In his Devonshire Plant Names the Rev. Hilderic Friend says "There is some confusion in the use of the trivial name of this plant. In Somersetshire this handsome climber is called CANARY CreEper, as though it belonged to the Canary Isles." But the term "Canary" surely refers to the bright yellow colour of the flowers and not to any supposed origin of the plant! Mr. T. IV. Cowan informs me that it is also called CANARY BIRD FLower, and that it comes from Peiu and Mexico.

Aimfrican Lmac. The Red Spur Valerian, Kentranthus ruber, is so called in Devon. In many parts of Somerset, Dorset, and Wilts it is known by no cther name than KISS-ME-QUICK.

ANGEL FLowER. A correspondent at Scokeunder-Ham gives me this as a lecal name for the Common Yarrow, Achillea Millefolium.

ANGer GABRIel. Several correspondents at South Petherton inform me that this name is there given to the Tiger Lily, Lilium tigrinum.

AxGels. (1) Correspondents at Symondsbury and Monkton Wyld, near Charmeuth, inform me that this name is there given to the Herb Robart, Geranium Robertianum.

(2) Winged seeds of the Sycamore, Acer Pseudo-platanus (Mello).

ANgers Axp Devirs. A general name in this part of England for the Wild Arum or Cuckoopint, Arum maculatum. Mrs. Day, of North Petlerton, tells me the light parts of the flowers are the Angels and the dark part the Devils.

ANGEIs' Exes. A name given in some parts of this district to the Germander Speedwell, Veronica Chamœdrys, more commonly called BIrds' EYes.

ANGLER's Flower. A correspondent at Ilminster gives me this as a local name for the Water Figwort, Scrophularia aquatica.

Ass's Foot. Several correspondents send me this old name for the Coltsfoot, Tussilago Farfara. Its popular name in France has the same meaning. 
ANGer's 'J'EARs. A South Petherton correspondent gives this as a local name for the Star of Bethlehem, by which I presume she means Ornithogalum umbellatum, although in Souserset the name "Star of Bethlehem" is applied to several other flowers.

ANGer's Trumpet. (1) 'The Common Thornapple, Datura Stramonium.

(2) Also to the flowers of Brugmansia suaveolens-a cultivated plant of the Nightshade family.

ANISE. (1) The real Anise is Pimpinella anisum. The furits (aniseed) are used fo. flavouring, \&c.

(2) This is one of several names given in this part of England to the favourite rockery plant, Alyssum maritimum, frequently called SWEET ALICE. The change from " 1 " to " $\mathrm{n}$ " and vice-versa is not uncommon in Somerset. where we say " chimley" for " chimney" and "snag" for "slag" (a sloe).

(3) The name is also given to the Myruh, Myrrhis odorata, an aromantic garden plant.

Apostres. Several correspondents at Thorne St. Margaret give me this as a local name for the Star of Bethlehem. I presume they refer to Ornithogalum umbellatum, although the name "Star of Bethlehem" is given in Somerset to several other flowers, particularly to the Greater Stitchwort.

Apple Blossom. See "Apple Shrub."

APPLE PIE. A very common name for the flowers of the Willow Herb, both the Great Hairy, Epilobium hirsutum, and the Rose Bay, $\boldsymbol{E}$. angustifolium.

ApPLE SHRuB. The Weigelia rosea, no doubt so called from ube likeness of its flowers to apple blossom. The plant has soon become naturalised, for Dr. Prior says it was only introduced from China in 185\%. It is now one of our commonest flowering shrubs. F. T. ELwORTHY (written in 1888). Mr. T. W. Cowan kindly informs me that the generic name has sirce been changed to Diervilla, and that the plant was introduced into England in the year 1844.

APSE. A name general throughout the South and West of England for the Aspen, Populus tremula. The late Mr. F. T. Elwortby says "Here is a good example of corruption by the literary dialect, while the much-abused Hodge has retained the true form." There is a tradition that the Cross was made of the wood of this tree, but the same story is attached to many other plants.

ARbale. Mr. F. T. Elworthy says this is the only name in West Somerset for the White Poplar, Populus alba. See ABBEy. 
ARB RABBITS o: ARBRoBERT. A corruption of the name Herb Robert, the common Wild Geranium, Geranium Robertianum. The late Mr. F. T. Elworthy quotes a man as saying "We calls em sparrow-birds, but the proper name's ARB RABBITS."

ARChanger. (1) The Yellow Dead Nettle or Weasel Snout, Lamium Galeobdolon. Also apflied to

(2) The White Dead Nettle, Lamium album; and

(3) The Red Dead Nettle, Lamium purpureum.

(4) The garden Angelica, Archangelica officinalis.

Arrist. A stubble of any kind after the crop is gone.

Arrow Rot. Mr.H. A. Bending, of Shoscombe (near Bath) gives this as one of the names applied in that district to the Cow-parsnip or Eltrot, Heraclerm Sphondylium. It is obviously a corruption of ALDERTROT, which sec.

Arrow Root. The TVild Arum or Cuskoo-pint, Arum maculatum. So called from the fact that Portland sago or arroweot was made from the tubers of this plant.

ARse-Surart. IVater Pepper', Polygonum hydropiper. The plant owes its local name to the irritating effect of its leaves.

ArTs. A name used in South-West Wilts and some parts of East Somerset for the Whortleberry, Vaccinium Myrtillus, known in West Somersct as "Worts." A correspondent at Donhead writes: "The Semley end of Donhead Cliff grows 'arts' in abundance, and. is called 'Ant Hill.' The Ordnance' Survey map has corrected (?) this into 'Hart Hill,' but 'Art Hill' is its proper name. A local industry is to go "arting "in the proper seasom of the year."

A.SS-SITARit. See ARSE-SMIART.

AsH CANDIES or AsH KEYS. The seed $\nabla$ essels of the Ash :Tree, Fraximus excelsior.

Ast-TVEED or ACH-WEED. : An old, but still fairly general namefor thecommon Goutweed, E gopodium Podagaria, of which Culpepper says "Neither is it to be supposed Goutweed hath its name for nothing; but upon experiment to heal the gout and sciatica; as also joint-aches and other cold griefs. The very beaving of which about one easeth the pain of the gout, and defends him that bears it from the disease."

AsHr Poker, A Tisbury correspondent gives this as a local name for the Hoary Plantain, Plantago media.

AUNT Barsy. A Watchet correspondent tells me that the "Crane's bill "- be does not say which of the Crane's bills-is called by this name 
in that district. Mr. 'T. Wr. Cowan kindly suggests probably Geranium columbinum, which is plentiful at Watchet.

AdNTIE Poury. A play upon the name Polyanthus. Used by young people in many parts cf the county.

AUstrutian Grass. A Somersetshire name for Pampas Grass, Gynerium argenteum.

AUTum Crocus. The Meadow Saffron, Colchicum autumnale.

Av EN Av (= Half-and-Half). A correspondent at Stoke-under-Ham gives me this as a local name for Haw's or fruit of the Hawthorn, Cratogus monogyna

BAA LAmBs. (1) Several young pople at Evershot tell me that in that district this name is given to the White Clover, Trifolium repens.

(2) The name is more generally given to the catkins of the hazil, Corylus Avellana.

BAA Lanbs' TAIls. Same as "Baa Lambs." (2)

BABE AND CANDLE. A correspondent at Dunster gives this as a local name for the Fumitory Fumaria officinalis, but I think there is possibly some confusion between this name and "Babe in the Cradle," by which the flower is known in other districts.

Babe IN THE Cradle. (1) Common Fumitory, Fumaria officinalis.

(2) Wild Arum or Cuckoo-pint, Arum maculatum.

BABES IN THE Cradle. Water Figwort, Scrophularia aquatica.

BABES IN THE WOOD. A correspondent at Hawkchurch (Devon) gives me this as a local name for the Lesser. Stitehwirt, Stellaria graminea.

BABIES IN THE ORADIE. Siapdragon, Antirrhimum majus-from one correspondent only at Monkton Wyld.

BABY CAKEs. Correspondents in the Ottery St. Mary district give me this as a lccal name for the Shining Crane's-hill, Geranium lucidum. (2).

BABY IN THE CRADLE. See BABE in the CR IDLE

BABY's Bonnet. The Sweet Pea, Lathyrus odoratus (Aller).

BABY's BREATH. The Gauze flower, Gypsophila paniculata.

BABY'S CRADLES. Sainfoin, Onobrychis sativa (Leigh, Dorset).

BABY'S PET. Common Daisy, Bellis perennis (Muchelney and Aller districts).

BABY'S PINAFORE. A correspondent near Axminster gives this as a lccal name for the Herb. 
Robert, Geranium Robertianum. - A number of correspondents in the Chard and S.E. Devon districts give the somewhat similar name DoLLY's Apron for the same plant.

Baby's Ratthe. (1) Yellow Rattle, Rhinanthus Crista-galli.

(2) Common Bugle, Ajuga reptans.

(3) A corresponaent at Axmmster gives this as a local name for the crested Cow-wheat, Melampyrum cristatum, but I think it possible there is some confusion in that district between this plant and the Yellow Rattle (see 1 above), as I gather both names are given rather freely to either of the two plants.

BABY's ShoEs. (1) Common Bugle, Ajuga reptans (S.W. Wilts).

(2) Columbine, Aquilegia vulgaris (Mucheiney).

BACCY. Plantain, Plantago. The stringy leaves are supposed to beal some resemblance to tobacco (Keinton Mandeville).

BACCY LAarbs. The catkins of the Hazel, Corylus Avellana (Mells). S Se BAA LAMBs' TAسs.

Baccy Plant. Coltsfoot, Tussilago Farfara. This name has been sent me by one South Petherton correspondent only, but the name is probably not uncommon in view of the facts that for nearly 2,000 years the plant has been smoked through a reed to relieve pain, and the leaves are said to form the basis of the British herb tobacco.

BACHELOR's BUTTONS. A name which has been applied to a large number of flowers chiefly on account of their button-like shape and appearance. Dr. Prior says the name is given to several flowers "from their similitude to the jagged cloathe buttons, antiently worne in this kingdom " according to Johnson's Gerarde, p. 472, but ascribed by other wiiters to "a habit of country fellows to carry them in their pockets to divine their success with their sweethearts." Britten gave a list of 17 plants so named, but he did not by any means exhaust their number. Rev. Hilderic Eriend gives eight plants to which the name is applied in Devon, but he does not include either of the two plants to which I have found it most frequently given in Somerset, viz :-

(1) Greator Stitchwort, Stellaria Holostea.

(2) Marsh Masigold, Caltha palustris.

(3) MI". Friend includes Field Scabious, Scabiosa arvensis, in his Devon list, but says the name is given more frequently to this plant in Somerset than in Devon.

(4) Perhaps the plant to which the name is most frequently applied in the West of England is the Common Feverfew, Chrysanthemum Parthenium. 
(5) From several parts of Somerset correspondents tell me the name is given to the Red Campion, Lychnis dioica.

(6) From several districts in North Somerset I hear the name is given to the Ragged Robin, Lychnis Flos-cuculi; and the Rev. Hilderic Friend says the name is given to this flower in Devon, although not commonly so; but it is the only name for the plant in some parts of Sussex.

(7) Several young people at 'Thorne St. Margaret tell me that in that district the Periwinkle, Vinca major or $\mathrm{V}$. minor, is known by this name.

(8) The Wall Pennywort, Cotyledon UmbilicusVencris.

(9) Headow Crowfoot, Ranunculus acris, and other Buttercups.

(10) The burrs of the Burdock, Arctium majus.

(11) The Gorn Bluebottle, Centaurea Cyanus.

(12) Siveral correspondents at Bradford-onTone tell me the name is in that district applied to the common Tansy, Tanacetum vulgare.

(13) The Japenese shrub Kerria (or Corchorus), japonica, popularly known in the West of England as the Yellow Rose.

(14). The Chrysanthemum. The old-fashioned variety (now seldom seen), bearing bunches of small button-shaped, dark red or yellow flowers. Name in general use in neighbourhood of TVellington.

BACHELOR's PILLAR, given me by a young person at Otterhampton as a local name for the Ice plant Mesembryanthemum, but probably there is some confusion between this and the following name :-

BACHELOR's PILLOT, given me by a correspondent at Wambrook as the local name for the prickly Cactus.

BACON. A correspondent at Leigh-on-Mendip informs me that this name is given in that district to the young shoots of the Wild Rose, Rosa canina.

BacoN AND EgGs. (1) The Jonquil, Narcissus Jonquilla, and also other kinds of Nareissus.

(2) The Water Crowfoot, Ranunculus aquatilis.

(3) Yellow Toadflax, Iinaria vulgaris (N.W. and S.W. Wilts).

BACON-TVEED. White Goosefoot, Chenopodium album (Dorset).

BACK тo BACK. Several young people at Axbridge give me this name for the Pansy, Viola tricolor.

BAD LUCK BERRIEs. Elder Berries, Sambucus nigra. I have this name only from one young person at Draycott. I know no reason for the name except possibly the tradition that it was upon an Elder tree that Judas hanged himself. 
BADGER's Flower. Broad-leaved Garlic, Allium ursinum (N.W. Wilts).

Balduoney, Bawdmoney, or Badmoney. The Spignel Mew, Meum Athamanticum, one of the umbelliferous plants. Dr. Prior gives the derivation of the name as a corruption of the Latin valde bona-." exceedingly good "; but Sir Wno. Hooker considers it a corruption of Balder, the Apollo of the North, to whom the plant was dedicated.

BALLAMs. Correspondents at Bridgwater give me this as a local name for the Sloe or fruit of Prunus insititia.

BalM of GILEAd. Wild Balm, Melittis Melissophyllum (Wilt's).

BaLM OF THE WARRIOR'S WOUND. Perforated St. John's Wort, Hypericum perforatum. The aame is due to the fact that the flowers of this plant were very extensively used for many years in the preparation of an ointment remarkable for its healing properties.

BAnre. The West Somerset promunciation of Balm, Melissa officinalis.

Banewort. The Deadly Nightshade, Atropa Belladonna.

Banjo Leaves. Leaves of Plantai 1, Plantago (Yeovil).

BAN-NUT. The Walnut, Juglans regia. I believe this word is more particularly used in the North of Somerset and in Gloucester, but the Rev. W. P. Williams, of Bishop's Hull, included it without comment in his glossary in 1873, and added the couplet :-

A woman, a spaunel, and a bannut tree,

The mooar you bate' em the better they be.

BARBED ARROWS AND FISH-HOOKS. A Taunton lady gives me this name for (presumably the seeds of) the Dandelion, Taraxacum officinale.

BARBER's Brush. A fairly common name in Somerset, Dorset, and Wilts for the Wild Teasel, Dipsacus sylvestris.

BARREN STRAwBerRy. The Strawberyy-leaved Cinquefoil, Potentilla sterilis, of which the leaf and flower are almost exactly like those of the Woodland Strawberry, but which is not a strawberry, and bears no fruit in the popular sense. Children in some parts of Somerset give its blossoms the appropriate name of STORY-TELLERS.

BAsE Rocket. Wild Mignonette, Reseda Luteola, so called from its rocket-like leares, and its being used as a base in dyeing woollen cloths. Also called DYer's WEen and WELD.

BAssinet (i.e., "little basin"). An old name for the Meadow Crowfoot, Ranunculus acris.

BAskets. Ribwort Plantain, Plantago lanceolata (Little Langford, Wilts). 
BASTARD BALY. A number of correspondents send me this name, which is the usual English name for the Wild Balm, Melittis Melissophyllum, and is given to mark the distinction between this and the true Balm, Melissa officinalis, which belongs to another genus.

BASTARD Kruler. The plant Savin, Juniperus Sabina (F. 'T'. Elworthy). Dr. Downes tells me it should be $J$. communis.

Bath Asparagus. The Spiked Star of Bethlehem, Ornithogalum pyrenaicum. Rev. R. P. Murray says "The young spikes are sold in Bath as a substitute for asparagus, and are said by some to be little inferior in flavour."

BAYZuRE. A correspondent at Babcary gives me this as a local name for the Primula Auricula, which Mr. T. W. Cowan tells me is also called BAZIERs. Both forms are probably a corruption of BEAR's EARS, which see.

BEACON WEED. White Goosefoot, Chenopodium album. A Dorset pronunciation of BACON WEED.

Beads. Procumbent Pearlwort, Sagina procumbens (N.W. Wilts).

Beam Tree. A species of wild Service, of which the general English name is White Beam Tree, Pyrus Aria. Closely allied to the Mountain Ash.

BEAR BIND. Field Convolvulus, Convolvulus arvensis; so called from its binding together the stalks of bear or barley.

BeARded PINK. Sweet William, Dianthus barbatus.

BEAR's BREECH. (1) The English name of the genus Acanthus.

(2) The Cow Parsnip, Heracleum Sphondylium. Dr. Prior says the name has been transferred by some mistake from the Acanthus to the Cow Parsnip, and that it is given owing to the roughness of the plant.

Bear's Ears. The Auricula, Primula Auricula. The name "Bear's ears" is from the former Latin name of the plant, ursi auricula, in allusion to the shape of its leaf.

BEAR's Mouth. Snapdragon, Antirrhinum majus.

BEAR's Foot. (1) The Foetid or Stinking Hellebore, Helleboris foetidus, from the shape of its leaf. Also the Green Hellebore, $H$. viridis.

(2) Monk's-hood, Aconitum Napellus, because its much divided leaves are supposed to bear some resemblance to the paw of a bear.

BEATy Eyes. The Pansy, either cultivated, Viola tricolor or wild V. arvensis. See BIDDx's EYES. 
Bedstratws.-A correspondent at Stockland (Devon) gives me this as a local name for the Tufted Vetch, Vicia Cracca.

BEDWIND or BeDtrine. Traveller's Joy, Clematis Titalba (Dorset and Wilts).

BEE BREAD. A name given to sevaral flowers which provide honey, particularly

(1) White Clover, Trifolium repens, and

(2) Common Borage, Borago officinalis, which is frequently grown for the purpose.

BeE Catchers. Common Foxglove, Digitalis purpurea. I am indebted for this name to Mr. A. Stenning, of Batcombe, who tells me that when the bee is in the flower boys close the entrance to be amused by the insect's struggles. EYES.

BeEdx's Eyes. See BEATy Eyes and BIDDY's

BeE Flower. The Bee Orchis, Ophrys apifera. Also any flowers purposely grown near an apiary as sources of $\mathrm{h}$, ies. A cormespondent at chard mentinns Arabis alpina. Airs. Lansdowne, of Over S nwey, givas Anchrisr.

BeE Hives. Mr. A. Matthews, of Camerton, gives me this as a local name for the Foxglove, Digitalis purpurea. alb $\mathrm{im}$.

BEE NETTLE. (1) White Dear Neiıle, Lamium

(2) A come:sp ndent at North Petherton gires the ined Dead Tiettle, L. p rp rerm.

BeE's Nest. (1) The Wild Carrot, Daucus Carota; from the nest-like compact growth of its inflo:escenc: called also BIRD's NEST for the sam reacon.

(2) A Queen Camel correspondent gives this name for the Cow Parship, Heracleum Sphondylium, commonly known in East Somerset as Eltrot.

BEE's REsT. S veral correspondents at South Petherton gives this as a local name for the Water Lily. I presume they mean the Common Yellow Water Lily, Nymphxa lutea.

BegGaR's BAsket. Common Lungwort, Pulmonaria officinalis.

BegGar's BLANket. Great Mullein, Verbascum it hapsus.

BEgGaRs' ButTons; The flowerheads or burrs of the Burdock, Arctium majus.

BEGGARS' LICE. (1) A vulgar name given on the Gloucester border of Wilts to common grass seeds, p rticul r y Gastridi m lendigєrum.

(2) Given more generally to the seed burrs of the Goosegrass or Cleavers, Galium Aparine. Also to other plants having burrs with hooked prickles.

BegGar's NeEdLe. Shepherd's Needle, Scandix Pecten-1 eneris. 
Beggar Weed. (1) The Ciover Dodder, Cuscuta Trifolii, from its destructiveness to Clover, \&c. Also

(2) Greater Dodder, Cuscuta europos.

Berla Donna. The Deadly Nightshade, Atropa Belladonna. This name is Italian, and means "fair lady"; it is said to have been given to this plant owing to its berries being used by the Italian ladies as a cosmetic.

Bell-Bind. (1) Field Bindweed, Convolvulus arvensis.

(2) Hedge Bindweed, Calystegia sepium.

BELL-Flower. (1) A common name for the Daffodil, Narcissus Pseudo-Narcissus, from its shape.

(2) For the same reason any plant of the genus Campanula, including the popular Harebell, C. rotundifolia, which is known as the Bellflower in many parts of Somerset, Dorset, and Devon.

BELL HEATHER. The large flowering pink or white Heather, Erica Tetralix.

BELLOWS FLOWER. Dicentra spectabilis, which has a great variety of popular names, including Bleeding Heart, Lady's Lockets, Lyre Flower, Dutchman's Breeches, \&c.

BELL Rope. Daffodil, Narcissus PseudoNarcissus. I have only heard this name from Mr. W. C. Baker (a gardener). I asked him if he was not confusing it with "Bell Rose," but he was rery emphatic that he had heard the flowers called Bell Ropes.

BeLL-Rose. One of the commonest names for the Daffodil, Narcissus Pseudo-Narcissus.

BeLluMs. A Watchet correspondent gives me this as the local name for the Bullace, the fruit of Prunus insititia.

BENNETs. Long Coarse Grass; long stems of various Grasses, particularly Agrostis; used both of withered stalks of coarse grasses and of growing heade of Cat's Tail, \&c. Also long Plantain Stalks and Seedheads. I am indebted to Mr. T. W. Cowan for the couplet

\section{Pigeons never know no woe}

Till they A-BenNETming do go.

BENT-Grass. Any wiry grass, such as usually grows upon a common or other neglected broken ground.

Bents. See Bennets.

BERGanters. Mr. Edward Vivian, of Trowbridge, gives me this as the local name of a small, sweet, green pear; probzbly a corruption of BERGAMOT.

BERRY HoLtY. Holly with berries, Ilex Aquifolium (East Somerset, and Wilts). Mr. Vivian tells me that in the Trowbridge district this is the usual name for Holly. 
BERRy Hols. Holly with berries (Wiveliscombe).

Besom. The Broom plant, often called Green Besom, Cytises scoparius. An infusion of the leaves of this plant is held to be the great specific in dropsical eases.

BethleHey Star. (1) Correspondents in various parts of Somerset, Dorset, and Wilts give me this as a local name for the Cineraria.

(2) A correspondent at Brompton Regis gives it as a local name for the St. John's Wort, Hypericum.

BIBLE LEAF. (1) A correspondent at Stockland (Devon) gives this as a local na me fo: the St. John's Wort, Hypericum.

(2) Another Devonshire correspondent at Buckerell, near Honiton, gives it as a local name for the Wood Spurge, Euphorbia amygdaloides.

BIDDYs-Eyes. A very general name in Somerset for the small Wild Pansy or Heartsease, Viola arvensis. "Biddy" means a chick.

BIGGOTY LADY. A correspondent at Evercrecch gives me this as a lucal name for the B9.lse $m$ or Touch-me-not, Impatiens Noli-metangere. Both the popular and the scientific names of the plant have reference to the remarkable way in which its ripe seed pods burst with great violence on the slightest touch and scatter the seeds to quite a long distarce.

BIGOLD. A correspondent at Watchet gives me this as a local name for the Corn Marigold, Chrysanthemum segetum. The name is an old English one, and generally obsolete. It is very interesting if it still survives to any extent in West Somerset.

BHBERRY. Quite a general name for the Whortleberry, Vaccinium Myrtillus.

BILL Button, The Water Avens, Geum rivale (S.W. Wilts).

BILLERS. A name given in Devonshire to the flowers of any large umbelliferous plant, such as Cow-parsnip, Chervil, \&c. Known as Bullers in West Somerset.

Billy Busters. Mr. H. A. Bending, of Shoscombe (near Bath) gives me this as a local name for the Bladder Campion, Silene Cucubalıs.

BILly Buttons. This name is given to a variety of plants in different districts.

(1) In Devon it is applied to the flower-heads of the Burdock, Arctium majus, from the way in which they adhere to the clothing, and boys often stick them down the front of their coat or throw them lightly against the clothing of otber persons, to which they sling. 
(2) In Somerset and Wilis the name is frequently given to the commois Daisy, Bellis perennis.

(3) A correspondent at Bridgwater tells me that in that district the Field Scabious, Scabiosa arvensis, is known by this name as well as BACHELOR'S BUTTONS.

(4) Several correspondents at. Wembdon tell me the name is in that district given to the Hollyhnck, Althea rosea.

5) Correspondents at Bridgwater and Axminster give it as a local name for the Mallow, IIalva sylvestris.

(6) The Headmaster of Pensford Schools tells me it is applied in that district to the Marsh Marigol, Caliha palustris.

(7) I con po dent at Bishopswood gives it as a local name for the White Campion, Lychnis alba.

(8) Buttercup, Ranunculus acris (North Cadbury).

(9) Greater Stitchwort, Stellaria Holostea (Iwerne Minster).

BHLY-o'-Butrons. A correspondent at Leighon-Mendip gives this as a local name for the Marsh Vierig li. Caltha palustris.

Bilux's Burron. The Water Avens, Geum rivale (Durington, Wilts).

BINE LH.IEs. A name given in some parts of Dorset to the flowers of the Hedge Bindweed, Calystegia sepium, and of the Field Bindweed, Convolvul s arvensis. See BELL-BIND.

BIRD CAfies. A name given by young people to Capsicums, because it is possible to strip off the red skin envaring of the seed vessel and leave a net-work if fise surrounding the seed. Dr. Downes suggest; this name and practice apply rather to the Chinese Lantern Plant, Physalis.

BIRD Kуот GRAss. Common Knot Grass, Polygonum aviculare.

BIRDs. The winged seeds of the Sycamore, Acer Pseudo-platanus, from the way in which they fly through the air.

BIRDs' BREAD. Biting Stonecrop, Sedum acre. The reason for the name is unknown. Dr. Prior says "Apparentiy from no better reason than its appearance in blossom when young birds are hatched." The popular name in France has precisely the same meaning.

BIRDS' BREAD AND CHEEsE. Wood Sorrel, Oxalis Acetosella (Devon).

BIRDs' CHERries. A correspondent at Queen Camel tells me the Haws or fruits of the Hawthorn. Cratogus monogyna, are so called in that district.

BIRDs' Claws. Bird's-foot Trefoil, Lotus corniculatus (Axminster). 
BIRDSEed. (1) The heads of the Greater Plantain, Plantago major, which are gathered when ripe and dried for putting in the cages of tame birds as winter food.

(2) Common Groundsel, Senecio vulgaris, for the same reason.

BIRDs' ErE. A name given to a large number of different flowers.

(1) Most generally to the Germander Speedwell, Veronica Chamoedrys. Children frequently say that if you pick BIRDs' Eres the birds will come and piek your eyes out.

(2) In several parts of Scmerset the small Wild Pansy or Heartsease, Tiola arvensis, is kisown as the BrRds' Ere. Also the cultivated Pansy, $\nabla$. tricolor. Rev. Hilderic Friend says "In Somersetshire . . . a large yellow Pansy, for example, will be pointed out by the expression, "Look at this yellow Rird's Eye!"

(3) In West Somerset the name is sometimes given to the Eve: green Alkanet, Anchusa sempervirens, which is also known in that part of the county as the WATER FORGET-MIE-NoT.

(4) Correspondents at Thurlbear and Winscombe give it as a local name for the Chickweed, Stellaria media.

(5) The Rev. R. P. Murray gives it as being applied in the neighbourhood of Wells to the Birds'-foot Trefoil, Lotus corniculatis, more generally known as FINGERS AND THusibs.

(6) Several correspondents at Aller inform me that the name is there given to the Forget-me-not, Myosotis scorpioides.

(7) Several correspondents at Chew Magna tell me the name is there given to the Eyebright, Euphrasia.

(8) In some parts of Somerset and Dorset the name is given to the Brooklime, Veronica Beccabunga.

(9) In South-West Wilts the Scarlet Pimpernel, Anagallis arvensis, is often called the Birds' Eye. This flower is generally known in Somorset as the PoOr MAN's IVEATHER-GLass.

In Devonshire the name Bird's Eye is given (amongst other flowers) to

(10) The Herb Robert, Geranium Robertianum.

(11) The Red Campion, Lychnis dioica.

(12) Londori Pride, Saxifraga umbrosa.

BIRDs' MIEAT. Berries, either of Thorn, Holly, or Ivy. The name is often applied to Hips and Haws.

BIRDs' Nest. (1) The TVild Carrot, Daucus Carota, from the nest-like shape of its inflorescence.

(2) The Yellow Birds' Nest, Monotropa Hypopitys, from its leafless stalks resembling a nest of sticks, such as crows make. This is a very rare plant in Somerset. 
(3) A Dunster correspondent gives the name as being applied in that district to the Twayblade, Listera ovata.

(4) The Bird's -nest Orchis, Neottia Nidusavis, so called from the shape of its roots.

BIRds of Paradise. A correspondent at South Petherton gives me this as a local name for the Monkshood, Aconitum Napellus.

Birds' Pears. A name commonly given to both Hips and Haws, the fruits of the Wild Rose, Rosa canina, and the Hawthorn, Cratogus monogyna, respectively. Mr. W. S. Price, of Wellington, says :- "In West Somerset applied to fruit of Hawthorn only. The fruits of the Wild Rose are called Tom Tickleıs."

Birds' Peas. A name applied to most of our Vetches, Vicia, whose seeds, contained in pea-like pods, furnish food for various wild birds.

BIRD's Tongue. Common (or Bird's) Knotgrass, Polygonum aviculare.

BrRds' Wrivgs. Winged Seeds of the Sycamore. See Birds.

Birry-Holly. See Berry-Holuy.

Biscuit Flower. A correspondent at Sampford Brett tells me this name is given in that district to the Herb Robert, Geranium Robertianum.

Biscuit Leaves. A correspondent at Staple Fitzpaine says the leaves of the Beech, Fagus sylvatica, are so called in that district.

Bishop's Leaves. Water Figwort, Scrophularia aquatica. Dr. Prior says "from being known in French as l'herbe du siége, in reference to its remedial powers in hemorrhoidal affections, and this word siége being understood as of a Bishop's see."

BIsHOP's THUMB. A well-known variety of pear. (F. T. Elworthy.)

Bishop's Tongues. Mr. Edward Vivian, of Trowbridge, gives me this as a common corruption of BISHOP's THUMB.

BIshop's WeEd. Common Goutweed, Egopodium Podagraria.

BISHOPWORT. (1) Mr. T. W. Cowan gives me this as a name for the Woundwort, Stachys Betonica.

(2) Hairy Mint, Mentha aquatica (S.W. Wilts: Hants border).

Bissou. (1) In West Somerset, the Common Broom, Cytisus scoparius, from its use in making brooms or besoms.

(2) Common Ling or Heather, Calluna vulgaris. Largely used in the manufacture of besoms in various parts of the country. 
BIstort. The general English name for Polygonum Bistorta, from its writhed roots, Latin bis, twice, torta, twisted. Often known as Snakeweed.

Bimter Flower. Elder, Sambucus nigra (Axminster).

Brrter MIEdicine. A Bridgwater schoolmaster gives me this as a local name for the flower of the Elder, Sambucus nigra.

BittersadL. The Crab Apple, Pyrus Malus var. acerba, medning, of course, "as bitter as gall." Pulman says "It is often said of a soft, silly person:- 'He was born where th' bittersgalls da grow, and one o'm vall'd upon his head and made a zaate (soft) place there." "

BitTer-Sweet. (1) A general name for the Woody Nightshade, Solanum Dulcamara, because the rind of its stalk when it is first tasted is bitter and afterwards sweet.

(2) A very common and prolific apple ; uneat. able, but excellent for cider.

BLACK ALler. The late Mr. F. T. Elworthy, in his "West Somerset Word Book," says "The usual name for Buck-thorn, Rhamnus Frangula. 'Buckthorn' is never used." The name Black Aller or Alder is given to the shrub from its supposed resemblance to the Alder.

BLAckaMore. Great Reed-mace, Typha latifolia, more commonly known as the Bulrush or Cat-tails.

BLACK-A-MOOR'S BEAUTY. (1) A favourite name in Somerset for several varieties of Scabious, particularly the cultivated Sweet Scabious, Scabiosa atropurpurea, and the Field Scabious (or Knautia), S. arvensis. Another popular name for both flowers is Mournful WIDow. See also BLACK SOAP.

(2) According to Jennings the name is also given to the Musk-flower.

Black-beetle Poisox. A Taunton lady gives me this as a local name for the IWhite Dead Nettle, Lamium album.

Black Bent. The Slender Fox-tail Grass, Alopecurus agrestis. Dr. Watson tells me the BLACK BENT is really Agrostis nigra.

Black Brndweed. The Black Bryony, Tamus communis.

BLAcK BoYs. (1) A Wiltshire name for the Great Reed-mace, Typha latifolia, more commonly known as the Bulrush.

(2) In North West Wilts, the flower-heads of the Plantain, Plantago.

BLACK CAP. A Queen Camel correspondent gives me this as a local name for the Great Reed- 
mace, Typha latifolia, more commonly called Buirush.

BLACKens. A West Somerset term for Oats infested with "smuts."

BIiACK EYed SUSAN. (1) Correspondents at Over Stowey, Wells, and Muchelney give this as a local name for the Hibiscus-of which several species are cultivated in this country, perhaps the best known being $H$. Syriacus.

(2) Several young people at Aller inform me that the name is there applied to the Michaelmas Daisy, which is the popular nam? for several species of Aster, particularly A. Tradescanti.

Black Gipsies. Plantain, Plantago (Ubley).

BlackHeaded Pins. Miss Shute, late of Oare, gives me this as the local name for a Liver-Wort. Several of our county botanists have been good enough to give me the names of particular species to which the name is appied :

(1) Mr. T. A. Cowani gives the Brook or Common Liver-wort, Marchantia polymorpha.

(2) Dr. Watson gives Conocephalum conicum.

(3) Dr. Downes gives Pellia epiphylla, whose capsules strongiy resemble the black heads of pins.

BLACKHEADS. Spikes of the Great Reedmace, Typha latifolia, more commonly called Bulrushes.

Blackie Toppers. Same as Black-heads (Bridgwater).

BLACKIE Tops. Plantains generally (East Somerset).

Blacklead BRUsh. A correspondent at Thurlbeare gives me this as a local name for the seed of the Periwinkle, Vinca.

Black Man. Hoary Plantain, Plantago media, often called LAMB's TONGUE.

Black Рот-Herb. Horse Parsley, Smyrnium Olusatrum. The last of these names is Latin for "black pot-herb." See Alexanders.

Bt.Ack Puddings. Great Reed-mace, Typha latifolia; more commonly called BULRUSH.

BLACK SALLY. The Great Round-leaved Sallow, Salix caprea, from its dark bark (NorthWest Wilts).

Blacksmins. Plantain, Plantago (Batcombe).

BLAck SoAP. The Rev. Hilderic Friend says that in South Devon this name is given to

(1) The Field Scabious, Scabiosa arvensis; anc?

(2) The Knapweed, Centaurea nigra.

BLAcK Stroks. Graat Reed-mace, Typha latifolia, moi'e commonly known as Bulrush (Mells). 
Black Thistle. Marsh Thistle, Carduus palustris.

Blacktops. The Rev. R. P. Murray, in his "Flora of Somerset," gives this name as being applied, but very seldom, to the Privet, Ligustrum vulgare, in the neighbourhood of Wells.

BLACKY-MORE. Great Reed-mace, Typha latifolia, more commonly called Bulrush.

Bladder Bottre. Bladder Campion, Silene Cucubalus (Evercreech).

Bladders of LARD. (1) Bladder Campion, Silene Cucubalus (East Somerset).

(2) Wax Myrtle, Myrica cerifera (Over Stowey).

Blanket Flower. The general English name for the Gaillardia.

Blanket Leaf. (1) Great Mullein, Verbascum Thapsus, so called on account of the woolly texture of the leaf. The common name in Somerset.

(2) A small garden plant, the Wcolly Woundwort, Stachys lanata, commonly known in Somerset as Mouse's Ear or Donkey's Ear. It has woolly leaves, and is somewhat similar to the Mrullein, but smaller.

Blarntise. A correspondent at Camerton gives me this as a local name for the Wild Cress. I have endeavoured to obtain $f$ urther information, but without success, and shall be glad to hear from any reader who knows the name.

Blazivg Stars. Several correspondents send this as the popular name of the genus Liatristropical and sub-tropical plants of American origin belonging to the Composite order-known also by the name of BUTTON SNAKE-ROOT.

BLEEDING HEART. (1) Dicentra spectabilis known also as Dutchman's Breeches, Lyre, flower, Lady's Lockets, Duck's Bill, Locks and Keys, and by many other names.

(2) Also the Common Red Wallflower, Cheiranthus Cheiri.

(3) A correspondent at Wambrook gives the name to the Fuchsia.

BLEEDING WARRIOR.-A number of young people at Bradford-on-Tone send me this as a local name for the Wallflower, which is known throughout the greater part of the district as BLOODY WARRIOR.

BLEEDy WArrior. S Several correspondents in East Devon give me this as the local na mo for the Wallflower. See BueEnIxG and BLoody WARRIOR.

Blessed Herb. The Common Avens or Herb Bennett, Geum urbanum. "Bennett" is said to be a contraction of the Latin benedictus, 
meaning "blessed," and the plant owes this name to the fact that Platearius tells us that "where the root is in the house the devil can do nothing, and flies from it : wherefore it is blessed above all other herbs." He also says that if a man carries this root about him no venomous beast can harm him.

Blessed ThIstle. Carduus benedictus. It i said to owe its name "Blessed " to its supposed power of counteracting the effect of poison. The name is also given to Carduus marianus.

Blether Weed. The Bladder Campion, Silene Cucubalus (Dorset).

BLIDDY WIREs. A corruption of BLOODY WARrIors. A very general name in Somerset for all varieties of Wallflower, Cheiranth!s Cheiri, but particularly the dark red ones.

BLIND MAN. A name given in South-West Wilts to the common Red Poppy, Papaver Rhoas, which is locally supposed to cause blindness if looked at too long.

BLIND MAx's BuFF. A correspondent at Axbridge gives me this as a local name for the Traveller's Joy, Clematis Vitalba, more commonly known as Old Man's Beard.

BLIND Netrte. A name given to most of the Dead Nettles and Hemp Nettles, but perhaps more particularly to

(1) The White Dead-nettle, Lamium album. Dr. Prior says that in consequence of the leaves of the White Dead-nettle not harming or seeming to notice anybody, the plant bears in most languages a name that implies that it is dead, deaf, or blind.

(2) The Common Hemp-nettle, Galeopsis Tetrahit.

BLINKS or WATER-BurNks. Montia fontana. So called from its half-closed little white flowers peering from the axils of the upper leaves, as if afraid of the light.

Blister PIANT. The Meadow Crowfont or: Buttercup, Ranunculus acris, which, as its nam e suggests, is very acrid. It blisters the mouths of cattle if they eat it, and the hands of children who gather it. It is stated that tramps sometimes ruh its juice on their hands to raise blisters as evidence of their having done hard work.

BLoBs. (1) A fairly general name in Somerset and the adjacent counties for the Foxglove, Digitalis purpurea.

(2) In Wilts the name is given to the Yellow Water Lily, Nymphcea lutea.

BLOOD CUP. (1) A correspondent at Chelborough (Dorset) gives me this as a local name for the Woodruff, Asperula odorata.

(2) The Scarlet Elf-cup Fungus, Peziza coccinea, commonly known in Somerset as Soldier's Caps. 
Blood Flower. Any sed-flowering plant of the genus Hamanthus, of the Amaryllis family.

BLOOD HEART. A correspondent at Staple Fitzpaine gives me this as a local name for the Pentstemon.

Brood Walls. Mr. Edward Vivian, of Trowbridge, gives me this as a local name for the Wallflower, Cheiranthus Cheiri, which is also known in that district, as well as throughout the greater part of Somerset, as BLOODY WARRIORs.

BLOoD Wort. (1) The Bloody-veined Dock, Rumex sanguineus. One of our old writers remarks "All Docks being boiled with meat make it boil the sooner" ; and with regard to this particular species, he says that it is "exceeding strengthening to the liver, and procures good blood, being as wholesome a pot-herb as any grows in a garden; yet such is the nicety of our times (forsooth) that women will not put it into a pot, because it makes the pottage black; pride and ignorance (a couple of monsters in the creation) preferting nicety before health!"

(2) The name is sometimes given to the Herb Robert, Geranium Robertianum.

BLOODY BONES.

Orchis mascula.

(1) The Early Purple Orchis,

(2). The Wild Hyacinth, Scilla non-scripta (Dorset).

This is only one instance out of several in which I find a striking name given to one of these flowers being applied also to the other -in fact in many districts the Early Purple Orchis is known as the WILD HYACINTH, and a correspondent at Symondsbury (Dorset) tells me that in that district it is called BLUEBELL.

Broody Butcher. (1) The Red Spur Valerian, Kentranthus ruber.

(2) The name of a small red Apple.

Bloopy Dock. The Bloody-veined Dock, Rumex sanguineus, from its red veins and stems See BLOODwort.

Bloody FINGers. A very common name in Somerset for the Foxg!ove, Digitalis purpurea.

Bloody MaN's Finger. The Wild Arum or Cuckoo-pint, Arum maculatum, from its lurid purple spadix.

Bloodx Trionre. Miss Ella Ford, of Melplash (Dorset) gives me this as a local name for the Crimson Clover, Trifolium incarnati: $m$, and informs me that the name is due to a tradition which says that a battle was once fought in that neighbourhood in which the victors decked themselves with these flowers. It was a great massacre, and hence the name "bloody."

BLOODY Warrions. The usual name throughout Somerset for all kinds of Wallflower, Cheir- 
anthus Cheiri, but more particularly for the dark flowered variety. "Warrior" is said to be a coiraption of Wall-yer, ind Mr. T. W. Cow sn tels me that the plant is sometimes called BLOODY-WALLIER.

BLOODY WiRES. The latter portion of the nam i: simply a coiruption of "Warriors." See above.

BLooiry-Down. A fairly general name in Somerset for the Sweet-William, Dianthus barbatus.

Blosson. The flower of the Hawthorn, Cratagus monogyna-a very usual name in West Somerset. Mr. F. T. E.worthy quotes a question asked by a School Inspector in May, 1883 :"What do you mean by May?" (Several hands up) — "Blossom."

BLow BALL. The head of the Dandelion, Taraxacum officinale, in seed, from children trying to tell the time or read their fertunes by blowing away the seeds.

BLow-Flower. A correspondent at Rodney Stoke gives this as a local name for the Corn Blvebottle, Centaurea Cyanus. Query, a corruption of "Blue-flower."

BLow ME Down. The Sweet William. See BLoOMY-DowN.

BLow-Pufrs. The seed head of the Dandelion, Taraxacum officinale (Stoke-under-Ham).

Blue Basins. The Meadow Crane's-biil, Geranium pratense (Stration-on-the-Fosse).

BLUE BEARD. (1) Correspondents at Over Stowey, Machelney, and Camerton give me this as a local name for the Clary or Wild Sagie, Salvia Verbenaca.

(2) A correspondent at West Buckland applies the name to Nigella damascena, commonly known as Love in a Mist or Devil in the Bush.

Bluebell. In Somerset this name is most generally given to

(1) The Wild Hyacinth, Scilla non-scripta, but in Devonshire and in the parts of Somerset bordering on that county it is given to

(2) The Harebell, Campanula rotundifolia, which is also the "Blue-beils of Scotland."

(3) In several parts of Somerset and also in Devon, the Periwinkle, both Vinca major and V. minor, is known as the "Blue-bell."

(4) A coirespondent at symonc'sbury (Iorset) give $\mathrm{m}$ : this as a local name f(' $\mathrm{r}$ the Ear y Purple Orchis, Crchis mascula. See Bloody Bones.

Blue-BELls of ScothaNd. (1) The Harebell, Campanula rotundifolia.

(2) A correspondent at Sampford Arundel gives this as a local name for Love in a Mist or Devil in the Bush, Nigella damascena. 
Bude Betsy. The Puriwinkle, both Vinca major and $V$. minor (Dun'ster).

BLUE BLOW. A correspondent at Wimborne gives this as a local name for the Coin Bluebottle, Centaurea Cyanus.

Blue Bonnets. (1) The Cornflower or Corn Bluebottle, Centaurea Cyanus.

(2) The Devil's-bit Scabious, Scabiosa Succisa.

(3) A correspondent at Hatch Beauchamp gives it as one of the local names for the Wild Hyacinth, Scilla non-seripta.

(4) Several corresponderts at Chew Magna give this as the local name for the S:ar Thistls, but there would appear to be some confusion hece, as Mr. W. D. Miller informs me that the plant generally known as the Star Thistle, Centaurea Calcitrapa, is not recorded from anywhere near Ohen Magna, and is extremely unlikely ever to bave occurred there.

Blue Botrle. (1) This is the general English name for the Corn Bluebottle, moie commonly known in Somerset as the Cornflower, Centaurea Cyanus, from the bottle shape of the involicie and its brilliant blue flower.

(2) Often given to the Knapweed, Centaurea nigra.

(3) In some parts of Som rset and Dorset and in S.W. Wilts the Wild Hyacinth O: Bluebell, Scilla non-scriptr.

(4) Miss Ella Ford, of Melplash (Dorset) informs me that in her district the name is given to the Monkshood, Aconitum Napellus.

(5) The Periwinkle, Vinca (Dowlish Wake).

Blue Butcher. (1) The Early Purple Orchis, Orchis mascula (Yeovil, South Pether-
ton, \&c.).

(2) A number of correspondents at Aller give this as a local name for the Bee Orchis, Ophrys apifera.

Blư ButTerfur. A correspondent at Muchelney gives this as a local name for the Larkspur, Delphinium $A j$ cis.

Brue Butrons. A name which is given to various blue flowers which have round heads.

(1) In Somerset perhaps most commonly to the Cornflower or Bluebottle, Centaurea Cyanus. (2) Field Scabious or Knautia, Scabiosa arvensis.

(3) The Devil's-bit Scabious, Scabiosa Succisa.

(4) Sheep's-bit Scabious, Jasione montana.

(5) Small Scabious, Scabiosa Columbaria.

(6) In some parts of Somerset, but more generally in Devon, the Periwinkle, both Vinca major and $V$. minor.

(7) A correspondent at Camerton tells me in that district the name is given to the Meadow Crane's-bill, Geranium pratense. 
Blue Caps. (1) Devil's-bit Scabious, Scabiosa Succisa.

(2) Field Scabious or Knautia, Scabiosa arvensis.

(3) Cornflower or Bluebottle, Centaurea Cyanus, from their tufts of blue flowers.

Blut Chains. The Common Wistaria, Wistaria sinensis.

Blof Curls. Common Self-heal, Prunella vulgaris (Shute, Devon, and Stalbridge, Dorset).

Blue Devil. (1) The Blue (or Stinking) Iris, Iris foetidissima (Stoke-under-Ham).

(2) Viper's Bugloss, Echium vulgare (Allerford).

Blue Endive. Wild Succory, Cichorimu Intybus.

Blue-Eyed Beauty. The Periwinkle, Vinca (Aller).

Blue-Eyed Mary. The Periwinkle, Vinca (Combe St. Nicholas).

BuUt Eres. Germander Speedwell, Veronica Chamoedrys, more commonly known as BIRD'sEYE ; but I have had the name BLUE-EYES sent me from each of the four counties.

Blue Goggles. A South-West Wilts name for the Wild Hyacinth or Bluebell, Scilla non-scripta. A correspondent at Donhead writes "When viewed from a distance Bluebells, growing in sufficient quantitias, resemble a blue baze. The flower gets this name from its effect in bulk, the mass of blue giving an idea of looking through blue glass."

Buue Golden Chain. The common Wistaria, Wistaria sinensis.

Bloe Grajifer Griggres. The Wild Hyacinth or Bluebell, Scilla non-scripta. The adjective "Blue" is used to mark the distinction between this flower and the Early Purple Orchis, which is also known as Gramfer Griggles over a great part of the area covered by this list.

Blue JACK. (1) The Periwinkle, Vinca major and $\nabla$. minor.

(2) A name given in the Over Stowey district to one or more species of Centaurea, which I cannot definitely determine; probably $C$. Scabiosa, or either of the plants given under BLUE-Bottle 1 and 2.

BLOE JACKETS. A correspondent at Oamerton gives this as a local name for the Violet, $\nabla$ iola.

Blue JacoB's Ladder. Greek Valerian, 'Polemonium cceruleum.

BLUt MICE. The Dog Violet, Viola canina (Curry Mallet).

BLUE on the Modntain. A correspondent at Stratton on the Fosse informs me that this is a name given by the children in that district to a 
flower which she believes to be the Verbena. D1. Watson tells me that "Snow on the Mountain" has a blue form as $\pi$ ell as a white, and be believes he has heard this called BLUE SNowox-THE-MIOUNTAIN in Somerset.

Blue Porson. A correspondent at Watchet gives me this as a local nam? for the Privet, Ligustrum vulgare.

Blue Poppy. Conespondents at Martock and North Petherton give this as a local name for the Cornflower or Bluebottle, Centaurea Cyamus.

Blue RoBins. Boruge, Borago officinalis (Everciecch).

Blue Rocket. Monkshood, Aconitum Napellus.

Bude Shirts. Periwinkle, Vinca (Over Stowey).

Blue Suock. Periwinkle, Vinca (Martock, Wiveliscombe, and High Ham).

Blue Star. Periwinkle, Vinca (Winsham and East Devon).

Blue Thistle. Viper's Biglozs, Echium vulgare (Allerfoiti).

Blue Trumpets. Wild Hyacinth or B'ueball Scilla non-scripte (Hatch Beauchamp).

Blue WarRtor. Maddow Crane's-bill, Geranium pratense (Dunkerton).

BLUE WeEd. Viper's Bugloss, Echium vulgare

Br.trder-Buss. Double Pink, Dianthus Caryoppyllus (Sampford Arundel).

Boar. Distle (or Thistle). Spear Pium? Thistle, Cricus lanceolatus. Mr. El,vorthy says "Probably this is a corruption of Bur-thistle, induced by the coasse rank growth of this variety -hence no doubt having becoms boar, it has developed into bull-thistle." Holloway says the plant owes its popular name to the fact that it has very strong prickles, and is so called in opposition to the Sow-thistle, Sonchus arvensis, which has weaker prickles.

Bodts. (1) Sweet Ped, Lathyrus odoratus (Tauntion).

(2) Seeds of the Maple, Acer campestre (Stalb.idge).

BobBIEs. (1) Ribwort Plaatain, Plantago lanceolata (Puddletown, Dorset).

(2) Herb Robert, Geranium Robertianum (Stalbridge).

BoBbivs. Ribwort Plantain, Plantago lanceolata (Milborne St. Andrew, Dorset).

BobBY Butrons. A correspondent at Watchet gives me this as the local name for

(1) Goosegrass or Oleavers, Galium Aparine.

(2) The Burdock, Arctium majus. 
Bоввт Hoop. Red Campion, Lychnis dioica, more commonly called ROBIN HOOD in Somerset.

Bовву's Butrons. (1) Marsh Marigold, Caltha' palustris (Chard and East Devon).

(2) Cornflower or Bluebottle, Centaurea Cyanus (Churchstanton).

(3) A correspondent at Buckland St. Mary gives it as a local name for the Knapweed, Centaurea nigra.

(4) Fruits of the Burdock, Arctium majus (Bridgwater).

Bовву's Eyes. Germander Speedwell, Veronica Chamædrys, more commonly called BIRD's-EYES.

BoB-Grass. Soft Brome-grass, Bromus hordaceus (Dorset and S.W. Wilts).

Boв-RoвeRT. Herb Robert or Will Geraniurn, Geranium Robertianum (Melplash, Dorset).

Bов RobIN. The Red Campio,, Lychnis dioica (South Petherton and Ilminster district and West Wilts).

Bog-Bean. The Buck-bean or Marsh Trefoil, Menyanthes trifoliata.

Bog Bell. The Marsh Andromedi, Andromeda Polifolia, a very rare plant found on the Somersat peat moors.

Bog RHuBARB. A Martock correspondent gives this as a local nam? for the Butterbur. Petasites ovatus.

Bog Violet. The Butterwort, Pinguicula vulgaris, a rare plant found on the peat moors.

Bolloms. Blackthorn blossom, Prunus spinosa (Kimmeridge, Dorset).

BoNNET. The long grass which always appears in pasture fields when not mown for hay. The cattle do not eat it unless it is mown. The seed-stems of the blade grasses which the cattle will not eat. Called BENT, BENNET, in other places.-F. T. ELworthy.

Bonnets. A correspondent at Bradford-onTone gives me this as a local name for the Culumbine, Aquilegia vulgaris. See GRANNY's BONNETS.

Bonnet Strings. Long Grass or Bents. Spe BONNET.

BooK-LEAF. (1) Tutsan, Hypericum Androsemum. I have this name from several correspondents in South and West Dorset. Mr. F. W. Mathews tells me that in the Western Blackdowns it is called TIPSY-LEAF ("Tipsy," like "Titsum," is no doubt a corruption of "Tutsan ") or BIBLELEAF for the reason that the leaves are often placed in Bibles, on account of the pleasant perfume given off by the dried sprays. 
(2) Correspondents at Wambrook give this as a local name for the St. John's Wort, by which may be intended the Tutsan as mentioned above, or one of the other species of Hypericum.

(3) A correspondent at Furley gives it as a local name for the Hare's-ear or Thorow-wax, Bupleurum rotundifolium.

Boot Butrons. Berries of the Privet, Ligustrum vulgare (Over Stowey).

Bootes. MIr. T. W. Cowan gives me this as an old name for the Marsh Narigold, Caltha palustris.

Bоot Polish. Cherry Blossom, Prunus avium, an interesting instance of school-boy humour and of the value of advertising (Evercreech).

Boots AND Shoes. A name given to several different flowers, but apparently in Somerset most generally to

(1) The Columbine, Aquilegia vulgaris.

(2) Bird's-foot Trefoil, Lotus corniculatus (also in Devon).

(3) A Bridgwater correspondent gives it as a local name for the Vetch, Vicia, but does not indicate the species. Mr. T. W. Cowan suggests possibly Lathyrus Aphaca, which is found near Bridgwater.

(4) In East Somerset the winged seeds of the Ash, Fraximus excelsior, and of the

(5) Sycamore, Acer campestre.

(6) The Rev. Hilderic Friend gives it as a Devonshire name for the Lady's Slipper, Cypripedium Calceolus, but Mir. WV. D. Miller points cut that this plant is excessively rare, and is not found nearer than Yorkshire, and suggests there has been some confusion with another plant.

(7) A correspondent at Broadwindsor (Dorset) gives this as a local name for the Suapdragon, Antirrhinum majus.

(8) A correspondant at Mrembiry (Devon) gives it as a local name for the IIonkshood, Aconitum Napellus; and also for the

(9) Double Polyanthus.

Boots ANd Stockings. Hoary Plantain, Plantago media (Ilminster).

Bosselt. The Corn Marigo'd, Chrysanthemum segetum (West Wilts).

Botherum. Corn Marigold, Chrysanthemum segetum (Dorset).

Bottles of Wine. Dicentra spectabilis, known by a variety of names, amongst others Bleeding Heart, Lady's Locket, Lyre Flower, Dutchman's Breeches.

Bouncing Bess. This is one of the names given in North Devon, and also in Dorset, to the Red Spur Valerian, Kentranthus ruber, known 
throughout a great part of Somerset as "Kissme-quick."

Bouncing Betsy. Another Dorset form of Bouncing Bess.

Bouncing Bett. (1) The Pansy, Viola tricolor (Ilton and North Petherton).

(2) Common Soapwort, Saponaria officinalis (Dorset).

Bour. A Martock correspondent gives this as a local name for the Elder, Sambucus nigra.

Boxing Gloves. Mr. J. Woodward, of Bridgwate!, gives we this as a local nam? for the Bird's-toot Trefoil, Lotus comiculatus.

Box of Matches. The leaf of the Maple, Acer campestre (Shoscombe).

\section{Box Thors. Lycium chinense (White's Bristo Flora).}

Boys. (1)The long pistilled or "pin-eyed" flowers of the Primrose, Primula vulgaris. "The shortpistilled Or" "thrum-eyed" or "rose-eyed" flowers are called GIRLS.

(2) Dr. R. C. Knight informs meth t in Dorset the namo is also given to the long-pistilled flowers of th? Cowsip, Primula veris.

Boys And Girus. Primroses, and (in Dorset) Cowslips. See Boys.

Boy's Love. Southernwood, Artemesia Abrotanum. Mr. Eiworthy says:- "A very great favourite with the village belles. In the summer nearly all carry a spray of it half wrapped in the white handkerchief in their hand to church. In fact a village church on a hot Sunday afternoon quite reeks with it." It is said that the plant owes this name to the fact that its ashes were formerly made into an ointment and used by young men to promote the growth of the beard,

Boy's Love and MaIden's Ruin. Sam as BoY's Love. The Southernwood is also known in Devon as MAIDEN's RuIN, and in some parts of the county the above combined name is given to it.

Bozzelt. Corn Marigold, Chrysanthemum segetum (West Wilts).

Brandy Bottle. A very common nam 3 for the Yellow Water-lily, Nymphra lutea, probably from the shape of the seed-vessel, although it is frequently said to be due to the odour of the flower.

Brandy Bottles. (1) Hips; fruit of the Dog Rose, Rosa canina (Shoscombe). (Dorset).

(2) Broasl-leaved Garlic, Allium ursinum

\footnotetext{
Brank. Common Buckwheat, Polygonum Fagopyrum.
} 
Bread And Bacon. Siveral young people at Aller give me this as a local nam 3 for the Narcissus.

BREAD AND BUTter. (1) A correspondent at Staple Fitzpaine gives this as a local name for the Silveriveed, Potentilla Anserina.

(2) A correspondent at Lottisham gives it as a local name for the Yellow Toadflas, Linaria vulgaris.

Bread AND Cheese. Another name which is applied to a number of difierent plants, the most common in this part of the countey being

(1) 'The young leaves of the Haivtlorn, Crategus monogyna, which children are very fond of eating. 'Tnis name is common nearly all over England.

(2) The Common Mallow, Malva sylvestris, frequently called (erroneously) Marsh Mallow. The round flat saeds of this plint rre eaten by children all over Engiand, and are called "Che zses."

(3) The Wood Sorrel, Oxalis Acetoseitice, of which the leaves and flower's are freely eaten, and are pleasant and refreshing.

(4) In South-West Wilts the Yellow Toadflax, Linaria vulgaris.

(5) I correspondent at Cinilton Polden gives this .s a local name fo: the Valerian (? Kentranthus ruber).

(6) A correspondent at Wellow gives this as a. local name for the Silverweed, Potentilla Anserina.

(7) Bird's-foot Trefoil, Lotus corniculatus (Wiasham).

Bread and Cheese and Oider. Same as "Bread and Cheesc, 1, 2, and 3.

(4) Cocrespondents at Forton and Stoke $A b$;ot (Dorset) give this as a local name for the Wood Anemone, Anemone nemorosa.

Brean and Cheese axd Krsses. Common Mallow, Halva sylvestris (Stocklanci, Bidgwater).

Bread AND Cheese-Cakes. A variation of the last name sent me from Wincanto $\Omega$, Common Mallow, Malva sylvestris.

Bread and Cheese Tree. The Hatwiholn, Cratcogus monogyna.

Bread AND Cider. The young leaves of the Huwho:n, Cratcegus monogyna (MLlis). See BRTID AND UHESE (1).

Biread and Marmalade. Mr. F. K. Summer-. hayes, of Mi!borne Port, gives me this is a local name fo: the Charloek o: Wild Mrestard, Brassica arvensis.

BREAD AND MrLK. A 'Taunton coirespondent gives this as a local name for the Wood Sorrel, Oxal is Acetosella. 
BREAK BASIN. A number of coriespondents in the Chard and Ea $t$ Devon districts give this as a local name for the Gesmander Speeciwell, Veronica Chamadrys, more generally known as BIRD's-EYEs. The name is probably due to the petals all filling off together very quickly after the flower is picked, thus breaking the basin. See SPEEDWELI.

Break JACK. Miss Ella Ford, of Melplash (Dorset), gives me this is a local name for the Lesser stilchwort, Stellaria graminea. Compare SNAP-JACK.

Breakstone. Any plant of the Saxifiage family, Saxifraga. An old Latin name used by Pling, derived from saxum, a rock. and frango, to braak, so ealled because it was supprsed to break stones in the bladder.

Bridal Wreath. (1) Francoa ramosa, a plant bearing long rac mmes of small white flowers.

(2) The name is sometimes given in South Somerset to Campanula pyramidalis.

BRIDE CAKE. A corresponcient at Strattonon-the-Fosse sends me this as the local name for a flower which she believes to be an Arabis.

Bright Ere. Germander Speedwell, Veronica Chamodrys, more commonly culled BIRD'S-EYE (Mel!s and Brompton Regis).

BRIMBLE or BRIMmLE. Bramble, Rubus fruticosus. Here again the despised dialect remains true, while the literary dialect is the corrupt (from AngloSaxou, Bremel).

Bristol Rock Cress. The usual English name of the rare plant Arabis stricta, only found near Bristol, but Mr. IV. D. Miller tells me it has been introduced at $W \in \operatorname{mbd}$ bn and elsewhere. A correspondent at Leigh-on-Mencip tells me this name is applied in that district to the ccmmon rcckery plant, generally known as "Snow on the Mountain "-by which is probably meant Arabis scabra or $A$. albida, or Koniga (formerly $A l y s s u m$ ) maritima.

Broad Grass. Common Red Clover, Trifolium protense (Dorset).

BROAD WEED. The Cow-parsnip, Heracleum Sphondylium (Dorset).

Brocklo. A very common pronunciation of BrocCOLI in East and West Somerset and West Wilts.

Brook LIME. This is the general English name for Veronica Beccabunga. Mr. T. W. Cowan tells me it is a corruption of the older names, Brolilembe, Broklemip, Broclempe, as if it was so called from growing in the lime or mud (Lat. limus) of brooks. Markham (1637) spells the word Brockelhempe, as if it equalled "britlle-hemp." 
The name Brook LIme is frequently given in Sinmerset (in errcr) to

(1) The Water Pimpernel or Brookweed, Samolus Valerandi.

(2) The Rev. R. P. Murray says that in the Wincanton district the name is given to the Procumbent Marshwort, Apium nodiflorum, often called Fool's Watercress or Cow-cress. I am. indebted to Dr. Watson for the following note:"Some of the names are undoubted misnomers, which one must be careful not to perpetuate, e.g., Brook Lime for Brook Weed is a lccal error almost certainly due to similarity of sound, and I should expect that the name when given to Marshwort is due to a mistake. Brook Lime, Marshwort, and Water-cress are almost invariable asscciates in ditches, and I have often heard the Marshwort miscalled Brook Lime, but when the mistake was pointed out the observer realised the mistake. The mistake was probably originally dise to the real plant being pointed out as Brook Lime, but as the other was mixed with it the observer confused the two."

Brooy. (1) The real Broom, with its masses of golden pea-shaped flowers, is Cytisus scoparius: but a correspondeat at Axminster gives "Broom" as a local name for the Heatber, Calluna vulgaris. The explanation of the name is no doubt that given under BIssour.

(2) Mis. Day, of North Petherton, and correspondents at Brompton Regis tell me that this name is given in those districts to the commo Furze or Gorse, Ulex europaus. Dr. Watson writes, "The application of Broom to Ling and Furze is also due to confusion, and so far as I know is very local."

Brooms AND BRushes. A correspondent at Evershot (Dorset) gives me this as a local name for the Wild Cornflower (? Centaurea nigra. or Centaurea Cyanus).

Brooze, or Brousse. Brushwood. (Bradfordon-Tone).

Brown BACK. The Common Ceterach or Scaly Spleenwort (fern) of our walls, Ceterach officinarim; mo:e often called RUSTYBACK in Somerset from the brown scales on the under surface of its fronds.

Brownet. A contraction of BRowN-WORT, which see.

Brown SugAr. Given me by a correspondent at Chew Migna as a local name for the common Sorrel or Sour-dock, Rumex Acetosa.

Brown-wort. (1) Water Figwort, Scrophularia aquatica.

(2) Knotted Figwort, Scrophularia nodosa.

(3) The name is often given to the Selfleal, Prunella vulgaris. Dr. P'ior says "trom its 
being supposed to cure the disease called in German die braune, a kind of quinsy."

Browse. Mr. W. S. Price, of Wellington, gives me this as a local name for under-growth in a coppice or plantation. See BROOZE.

Bruisetrort. (1) Common Daisy, Bellis perennis

(2) Common Soapwort, Saponaria officinalis, from their supposed efficacy in bruises.

Brumare. Bramble, $R$ :bus friticos:s,-i:ev. W. P. WILLI.AMS.

Broscus. The Butcher's Broom. Ruscus acilleutis.

Brushes. (1) A crmmon name for the rrild Tease', Dipsacus sylvestris.

(2) Miss Ella Ford, of Melolash (Dorset), gives it as a Joc 1 name for the Broom, Cytisus scopari's; and also for

(3) 'The Common Mare's Tail, Hipp:ris vulgaris.

(4) A correspondent at Leigh (Dorset) gives it as a lecal name for the Small Knaprreed, Centaurea nigra.

Brushes AND Combs. (1) A name firly general throughout the district for the rild 'Teasel, Dipsacils sylvestris.

(2) A correspondent at East Harptree gives it as a local name for green twigs of fir (? young leaves of La!ch).

Brushwoov. A correspondent at Braifordon-Tone gives this as a lecal name for Pineneedles.

BRYONY. A correspondent at Hawkchirch (Devon) givas this as a local name for the (ineater Bindweed, Calystegia sepium.

Buck-BEAN. Marsh Trefoil, Menyanthes trifoliata.

BUCKSHORx. Common Buckthorn, Rhammus catharticus (Wincanton). Dr. Prior thinks the popular name originated in a blunder, the German Bux-dorn being mistaken for Bocksdorn, i.e., "Box-thorn" for "Buck's-thorn."

Bugle Blooms. A correspondent at Shaftesbury (Dorset) gives this as a local name for the Common Honeysuckle or Woodbine, Lonicera Periclymenum.

Bugloss. (1) This name is properly applied to the Small Bugloss, Lycopsis ariensis, and to the Viper's Bugloss, Echium vulgare, but it is sometimes given to the Common and the Evergreen Alkanet, Anchusa officinalis and $A$. sempervirens: In France the latter is called La Buglosse.

The nexme Bugloss is derived from two Greck words, meaning "Ox-tongue," and is given to the 
plant on account of the shape and the rough surface of its leaves.

(2) The Rev. Hilderic Friend says that in Devon the Forget-me-not, Myosotis scorpioides, is called Bug-Loss.

Bugs and Fleas. A correspondent at Bradford-on-Tone gives this as a local name for the Wild Dock.

Buldace. A Wild Plum, the frit of Prunus insititia, very akin to the sloe, but botanists make slight distinctions between the two. In Turner's Herball (1562) we read "I never saw in ail my lyfe more plent ${ }^{\prime}$ of . . . . bulles trees than in Sommersetshyre." See Christians. Mr. F. W. Mathews, of Bradford-on-Tone, writes "The Bullace, or Kestin, is twice as large as a Sloe, and makes good eating, which a wild Sloe most decidedly never does."

Bult Cup. The Marsh Marigold, Caltha palustris ('Thorne St. Margaret).

BUIL-DISTLE. The Spear Plume Thistle, Cnicus lanceolatus (West Somerset).

Bull Dogs. Mrs. H. Day, of North Petherton, gives me this as a name for the Snapdragon, Antirrhinum majus.

Bullen. Large Black Sloes; Bullace-plum, Prunus insititia.-Rev. W. P. WILLIAMS.

Bullers. The flowers of any umbelliferous plants, such as Chervil, Cow Parsnip, \&c. Pronounced BILlers in Devonshire.

Bull-FLower. The Marsh Marigold, Callha palustris. It has been suggested that the name is a corruption of "Pool-flower."

Bull Heads. A Taunton correspondent gives this as a local name for the Knapweed, Centaurea nigra.

Bulurvs. A kind of Wild Plum (Holloway); Large Black Sloes (Jennings). The $f_{1}$ uit of Prunus insititia. A'so called Bullies.

Bullison. Miss Audrey Vivian, of Trowbridge, gives this as a common local name for the Bullace, Prunus insititia, or Sloe, P. spinosa.

Bullocks. The Wild Arum or Cuckoo-pint, Arum maculatum (Stoke-under-Ham).

Bullock's ExE. A correspondent at Dunster gives this as a local name for the Houseleek, Sempervivum tectorum. I know this name is given to the plant in the North of England, but I am not aware that it is used in Somerset.

Bull RUsh. (1) A number of young people at Muchelney tell me this name is given in that district to tha Reed (? Phragmites communis). Sise Buirush.

(2) A correspondent at East Harptree gives this as a lecal name for the Teasel, Dipsacus sylvestris. 
Butlus AND Cows. The Wild Arum or Cuckoo Pint, Arum maculatum (Furley, Wells, and Mells).

BULI's EYES. (1) Throughout a large part of Somerset, Dorset, and Devon this is a very general name for the Marsh Marigold, Caltha palustris.

(2) In some parts of Somerset and South Devon this name is given to the Red Campion, Lychnis dioica, but it is not so often used in the latter county as "Pocr Robin" or "Bird's-eye."

(3) Yellow Water Lily, Nymphara lr.tea (Wells and Leigh, Dorset).

(4) Ox-eye Daisy, Chrysanthemum Leucanthemum (Castle Cary).

(5) Mr. W. C. Baker (late of Maunsel) gives this as a local name for the St. John's Wort, Hypericum.

(6) Several young people at Aller give it as a local name for the Common Poppy, Papaver Rhoers.

(7) A correspondent at Shute (Devon) gives it as a lecal name for the Mallow, Malva sylvestris.

BulL's Foot. Correspondents at North Pethroton and Hawkehurch (Devon) give me this as a local nam? for th? Colt's foot, Tussilago Farfara. $R 2 v$. Hilderic Friend quotes the nane, but implies it is not commonly used.

Bull's Parsley. A correspondent at C'cmbe St. Nich olas gives $m$ this as a local name for the "Wild Parsley." (Probably Caucalis Anthrisc:s).

Bult Thistre. (1) This name is apparently applied to different thistles in different parts of the county, but most generally to the Spear Plum? 'Thistle, Cnicys lanceolatis. See BoxrDISTLE.

(2) The Marsh Plume Thistle, Cnicus palustris.

(3) Mrs. Day, of North Petherton, gives me this as a local name for the Black Knapwect, Centasea nigra.

Bultur. Wild Plum or Bullace, fruit of Prunus insititia (Devon).

Bully HeAds. Common Knapweed, Centanrea. nigra (Stogursey).

Bulrose. Britten and Holland say that J. R. Pulman gives this as the pronurciation of BELL-ROSE, which see.

Bulrush. The Bulrush of the botanist is Scirpus lacustris, but the name is probably not often applied to that plant by the ordinary inhabitants of somerset. The name is far more generally given to :-

(1) The Great Reed-mace, Typha latifolia, which owes its English name to the fact that it is this reed which appears in the "Ecce hrmo" pictures and familiar statues of Jesus as His mece or seeptre. 
(2) In som? parts of Somerset and Devon the name "Bulrush" is given to the Common Rush, Juncus conglomeratus; and it has been suggested that in this latter case the name is probably a corruption of pool-rush, whilst in the former case the name would probably be more correctly written "Bull-rush," in the sense that the Typha is large, and the descriptive prefix, "Bull " (like that (f "H(re"), implies something larger than the ordinary.

(3) A correspondent at Culmhead gives "Bulıush" as a lccal name for the Marsh Marigold, Caltha palustris. I learn from the Wilts Glossary that the Marsh Marigold is cccasionally ealled BuLrushes in S.W. Wilts from some nursery legend that Moses was hidden among its large leaves.

Bumble-bee Flower. A correspondent at Luxborough gives this as a local name for the Red Dead Nettle, Lamium purpureum. See BEE NetThe (2).

Bumble-BEes. The Bee Orchis, Ophrys apifera (North Somerset and East Devon).

Bumble-BerRy. (1) In North-West Wilts the Hip or fruit of the Dog-rose, Rosa canina.

(2) More generally the Blackberry, the fruit of Rubus fruticosus.

$\Lambda$ corruption of Bramble-berry.

BumbLE-KITES. A popular name in som? parts of England for the Blackberry, Rubus fruticosus; mentioned by the Rev. Hilderic Friend, but I am not aware that it is used in s om rset, although it is sent me by a correspondent at North Petherton.

Bunch o' DAIsIes. Yarrow or Milfoil, Achillea Millefolium (Leigh, Dorset).

BUNCH of Gripes. (1) A correspondent at Imminster gives this as a lecal name for the Foxglove, Digitalis p'irpurea.

(2) Dr. R. C. Knight tells mo the name is also applied to the unopened inflorescerce of Ampelopsis Veitchii.

Bunch of Kers. (1) The Cowslip, Primula veris (Ilminster district). In East Devon sometimes called KEYs of Heaven. An old name for the Cowslip is "Herb of St. Peter," and this latter rame wis probably suggested by the resemblance of its flower-heads to a bunch of keys.

(2) Furze or Gorse, Ulex europous (Shoscombe).

(3) The Ash, Fraxinus excelsior (Bradfordon-'lone), doubtless on account of its clusters of winged seeds, which are commonly called KEYS.

Buxchy. The Banksia Rose-always.-F. T. ELTORTHY. 
BUNxy RABBITS. (1) I very general name throughout the district for the Snapdragon, Antirrhinum majus. Used much less frequentiy for

(2) Yellow Toad-flax, Linaria vulgaris.

(3) Ivy-leaved Toad-flox, Linaria Cymbalaria (East Somei'set).

(4) Foxglove, Digitalis purpurea (Martock and Stoke-under-Ham).

BUNNy RABBIT's EARs. Bird's-foot Trefoil, Lotus corniculatus (Bridgwater).

Bunvy Rabbits' Mouths. Digitalis purpurea (Ilminster).

(1) Foxgiovu,

(2) Snaporagon, Antimhinum majus (Ilminster).

(3) Ivy-leaved Toad-flax, Linaria Cymbalaria (Ilminst:-1).

Bunvy's EARs. Greater Mullein, Verbascum. Thapsus (Iwarue Minster, Dorset).

Bunny's Mouths. Snapdragon, Antirrhinum majus.

Bur. The little round seed-pod of Galium Aparine. Also the seed of the Buidock, Arctium majus, and of the Boar Thistle, Cnicus lanceolatus.

Bunnet Rose. A very general ne me for the Burnet-lewvad Rose, Rosa spinosissima. Clorrespondents a, Wambrook give it as a lc cal ne me for tha Siveet-briar, Rosa Eglanteria-possibly through scme confusinn of the two species.

Burning Bush. A name given to several garden plants, but more particularly to

(1) Dictammes Fraxinella, which is said to give off so much essential. oil that in warm weather if a light be brought near it it will ignite.

(2) S veral correspondents give Kochia trichophylla or $K$. scoparia.

Burning Fire. Head of Dandelion, Taraxecum officinale (Bidgwater).

Burst Bellies oi Burst-Belly Pinks. Double Pinks or C'rnations, Dianthus plumarius or D. Caryophyllus (Hatch Beauchamp and Mark).

Bushr-BEARD. Travaller's Joy, Clematis Vitalba (Axminster).

Busters. Double Pinks (Camerton). Sae Burst Bellites.

Butcher Boys. (1) Eariy Puiple Oichis, Orchis mascula. (Thorncombe).

(2) Mr. F. R. Summshayes, of Milborne Port, gives it as being applied in that distriet to the Pyizmid Onehi', Orchis pyramidalis, the local name for the Early Purple Orchis being Granfer Griggies.

Butcher Flowers. Eaily Purp'e Orchis, Orchis mascula (Axbridge). 
Butchers. (1) Early Purple Orel is, Orchis mascula (South Petherton).

(2) Spottad Orchis, Orchis maculata (WViraliscombe).

Butcher's BLood. Ped Campion, Lychnis dioica. The Headmaster of Sexey's School gives me this name from a Siepton Miallet boy.

Butcher's Knives. Laves of the Iris (Bridgwater).

Butter. Lesser Gelandine, Ranunculus Ficaria (Sexey's School).

Butter ANd Cheese. (1) The Wood Sorrel, Oxalis Acetosella (from several correspondents at Bradford-on-Tone, Winsham, and Harkchurch).

(2) Lasser Cslandine, Ranunculus Ficaria (Winsham and Hatch Beauchamp).

(3) Common Mallow, Malva sylvestris (Stogursey and Ligh, Dorset).

(4) Creeping Buttercup, Ranunculus repens (South Petherton).

ButTer AND EGgs. A name given to a variety of flower:, but perhaps most generally throughout the district to

(1) Yellow Toxd-flax, Linaria vulgaris.

(2) The garden Narcissus of almost every varicts, including Jonquils and Daffodils, but particularly th se bering white flowers with yellow ce tres.

(3) Bird's-foot Trefoil, Lotus comiculatus.

(4) Wood Sorrel, Oxalis Acetosella (Bradfordon-Tone).

(5) A variety of the Primrose (Primula vulgaris) having a double calyx growing one out of the other. Not uncommon in the Hill district.-F. T. ELWORTHY.

(6) Rev. Hilderic Friend gives it as a name for the Ivy-leaved Toad-flax, Linaria Cymbalaria.

(7) Mr. J. C. Mansell-Pleydell gives it as a West Dorset name for the rare Spring Snowflake, Leucojum vernum.

BUTTER AND SUgar. A Tisbury correspondent gives me this as a local name for the Yellow Toadflax, Linaria vulgaris.

Butrer Chops. Lasser: Celandine, Ranunculus Ficarice (Evercreech).

BUTTERCUP. In addition to the various kinds of Ranunculus which usually bear this name it is frequently applied to

(1) The Lesser Celindine (Ranunculus Ficaria, and

(2) The Marsh Marigold, Caltha palustris. sometimes called "Water Buttercup."

Dr. Prior thinks that the name Buttercup is a colruption of Butlon-cop, i.e., Button-head.

BUtTer DaIsy. Ox-eye, Chrysanthemum Leucanthemum (Dorset and Devon). 
ButTeread EgGs. (1) Double Narcissus (Stoke-under-Ham).

(2) $A$ Tisbury correspondent gives me this as a local name for the Golden Saxifrage, Chrysosplenium oppositifolium.

Butter Fingers. Kidney-Veteh, Anthyllis Tulneraria (Aller).

Butterfles. (1) Sw set Peas, Lathyrus odoratus (Chard and Camerton).

(2) Sseds of the Sycamore, Acer Pseudoplatanus (Stoke-under-Ham).

Butter Flowers. A nams given, but less frequently, to all the flowers named under the heading of BuTTERCUP.

ButTerfly Flower. A common name for the Schizanthus family from the shape of the flowers.

Butterfly LAdies. A correspondent at Cerne Abhas gives me this as a local name for the Poppy, Papaver Rhocas.

Butter-JAGs.-The bird's-foot Tiefoil, Lotus corniculatus. Dr. Prior describes it as "an obscure name, perhaps in the first place BotTLEJACKS or BUTTER'D EgGS."

Butter Pumps. The seed vessels of the Yellow Water Lily, Nymphrea lutea (Dorset).

Butter Rose. (1) The Psimiose, Primula vulgaris (North Devon).

(2) The Rev. Hilderic Friend says Buttercups are so called in South Devon.

Butrery Egas. The Jonquil, Narcissus Jonquilla (Breamore, Wilts).

Buttons. (1) The flowers of the Feverfew, Chrysanthemum Parthenium (West Somerset).

(2) Mrs. H. Day, of North Petherton, gives it as a local name for the Musk Mallow, Malva moschata.

(3) A correspondent at Thorncombe gives it as a local name for the Teasel, Dipsacus sylvestris.

(4) The Burdock, Arctium majus (Evercreech).

(5) The burrs of various plants such as Goozegrass, Burdock, Thistles, \&c.

(6) Young Mushrooms.

Button Snake-Root. See Blazing Stars.

By-THE-WIND. Traveller's Joy, Clematis Vitalba (Farley, Wilts).

CABbage Flowers or CABbage Seed. Several correspondents at South Petherton give me this as a local name for the Charlock, Brassica arvensis.

Cabbage Rose. Several young people at Dunster tell me that this name (wbich is generally given to the Hundred-leaved or Provins Rose, Rosa centifolia) is in that district applied to the Peony, Paeonia officinalis ; I presume in reference to the size and shape of its flowers. 
CADDELT. Cow-parsnip or Hegweed, Heracleum Sphondylium (Devon).

CADLEY WobBles. A correspondent at East IIarptree gives me this as local name for Fir cones.

Cadweed. Same as Caddell.

Carns Axp Abers. (1) Columbine, Aquilegia vulgaris (S.W. Wilts).

(2) Mr. T. W. Cowan tells me that in other parts of the country the name Cain and Abel is applied to the tubers of Orchis latifolia.

CAkers. Cow-parsnip or Hogweed, Heracleum Sphondylium (Luxborough).

CAKE SEed (1) Cow-parsnip, Heracleum Sphondylium (Charmouth, Upottery, and Colyton districts). See KEX.

(2) Hemlock, Conium maculatum (Upottery).

CAKEzIE. Hemlock, Conium maculatum (Bradford-on-Tone). Often called Kex or Kexie in other parts of the county.

Call Me to You. Wild Pansy, Viola arvensis.

Caltrop. Saveral correspondents at Horton give this as a local name for the Crowfoot, Ranunculus (? acris). Mrr. T. W. Cowan writes me, "I do not know what Ranunculus this can be, but the name is applied to Centaurea Calcitrapa in other parts of the ccuntry. The specific name Calcitrapa suggests it to be a corruption of this."

CalvarT. False Hop, called Calvary from the spots of blood on the leaf (Wilts). "'Diogenes' Sandals," p. 85.

Calves-foot. (1) Wild Arum or Cuckoo Pint, Arum maculatum, from the shape of the leaf. It bears a similar name in France and Flanders.

(2) Coltsfoot, Tussilago Farfara.

Calves' Syout. Snapdragon, Antirrhinum majus.

CAMMICK or CAMMOCK. (1) A common name for the Rest Harrow, Ononis repens.

(2) Also applied in Devon to the Common Yarrow, Achillea Millefolium.

Caxpanelue. Hedge Convolvulus, Calystegia sepium.

CANARY BIRD Flower. See AMERICAN
Creaper.

CANARY CREEPER. Tropocolum peregrinum, frequently called "Canariensis." See AMERICAN CREEPER.

CANARY Flower. Greater Plantain, Plantago major, of which Anme Pratt says "Its tall spikes of greenish flowers, or the brown ripened seeds which succeed them, invite the possessor of the captive bird to carry the plant away for the meal of the songster." 
Canary Food. A common name throughout the district for (1) the Plantain, as above.

(2) Common Groundsel, Senecio vulgaris.

Canary Grass. Phalaris Canariensis, a grass * of the Canai'y Islands cultivated for its seeds.

Canary Seed. Plantain and Groundsel, as above.

Candle Berries. (1) Wax Myrtle, or Common Candleberry Myrtle, Myrica cerifera, a native of Canada, introduced in 1699 , and since grown in English gardens. Its round bo y nuts are covered with white wax, and are often gathered and used for making candles.

(2) Sweet Gale or Bog Myrtle, Myrica Gale, which grows freely on our Somerset peat moors ; its catkins produce a quantity of wax, though not nearly so much as the species mentioned above.

Candemias Berts. Snowirop, Galenthers nivalis (N.W. Wilts and G!os.).

Candlemas Caps. The Wood Anemone, Anemone nemorosa.

Candle Plant. A correspondent gives me this as a local name for "a varifty if cactu , having long cylincrical leaves, resembling small candles in shape, formerly often grown in cottage windows in West Somerset." I fancy he must mean the succulent plant, Kleinia articulata, which I have grown myself, and have frequently heard called the Candle Plant. It has cylindrical stalks, which very easily break off at the curicus joints, to which it owes its specific name. The leaves are not unlike small ivy leaves in shape.

Caxdles. (1) Biting Stonecrop, Sedum acre. (2) Flowers of Horse Chestnut, Esculus Hippocastanum. See Christunas CANDles.

(3) A correspondent at Melbury Osmond gives me this as a local name for the Meadow Sage, Salvia pratensis, which is a very rare plant, not found in this part of England. It is probable the plant she really meant was the Wild Sage, S. Verbenaca.

CANDLE-STICKS. (1) A name frequently given in Dorset to the Early Purple Orchis, Orchis mascula.

(2) Biting Stone-crop, Scdum acre (Leigh-onMendip).

(3) The Iris (Pawlett).

(4) Herb Robert, Geranium Robertianum (Kimmeridge, Dorset).

CANDLEwICK. Great Mullein, Verbascum Thapsus (Wimborne).

CANDock. (1) Miss Audrey Vivian, of Trowbridge, tells me this is a common name in that district for the Dog-grass. Exactly what is 
meant by "Dog-grass" is doubtful, but probabiy Cynosurus cristatus.

(2) Th? name is somotimes applied to the Water-lily, both white, Castalia alba, and yellow, Nympleci lutea.

CANKer. The Dog-rose, Rosa canina. Also the galls which grow upon it. See below.

CANKER-BALL. The mossy or hairy gall or " bedeguar," often of a bright searlet colour, found upon the Wild Rose, caused by an attack on a leaf bud in spring by the gall insect, Rhodites (or Cynips) Rosa. The growth is popularly known as Robin's Pincushion, and is often carried in the pocket as a charm against rheumatism.

CANKer Berries. Hips, fruit of the Wild Rose, Rosa canina.

Canker Rose. (1) Sime as Canker.

(2) Same as Canker-ball.

(3) Dr. Prior gives it also as a name for the Field Poppy, Papaver Rhoeas, in consequence of its red colour and its detriment to arable land. Mr. T. W. Cowan tells me that this name for the Poppy is quite common in the Eastern counties.

CAPRLFoy. Several correspondents at Shute (Devon) give me this as a local name for the Woodbine or Honeysuckle, Lonicera Caprifolium. One of the old names of the plant was Caprifoly or Caprifole (derived from two Latin words meaning Goat's leaf), of which the Shute name is a variation.

CARAVAUN-BEG. Mr. T. W. Cowan gives me this as a Somerset name for the Common Self-heal, Prunella vulgaris.

Cardinal Flower. A garden perennial of North American origin, having large deep red flowers, Lobelia cardinalis.

Carlicups. Marsh Marigold, Caltha palustris (Frome).

Carlies. Fircones (Sexey's School, Bruton).

CArline Thistle. The usual English name for Carlina vulgaris from Carolinus-pertainto Charles. So named after Charlemagne, of whom the legend relates "A horrible pestilence broke out in his army and carried off many thousand men, which greatly troubled the pious Emperor. Wherefore he prayed earnestly to God, and in his sleep there appeared to him an angel, who shot an arrow from a cross-bow, telling him to mark the plant upon which it fell, for that with that plant he might eure his army of the pestilence. And so it really happened." The herb thus miraculously indicated was this thistle.

Carnation Grass. (1) MIr. F. T. Elworthy says this name is given in West Somerset to the Hairy Sedge, a common dwarf sedge found in 
undrained meadow land, which is by some believed to be the cause of the coe in sheep. Carex hirta. Dr. Watson tells me the species can scarcely be called "dwarf," as he recently picked some nearly a foot in height.

(2) The name is also givan to certain other sedges, from the resemblance $\mathrm{cf}$ thoir leaves to those of the Curnation, more especially to Carex flacea and less commonly to $C$. panicea.

(3) In Gloucestershire the 'Iufted Hair-grass, Deschampsia caspitosa (Holloway).

Carpenter's Grass. Self-heal, as below.

Carpenter's Herb. (1) Self-heal, Prunella vulgaris. Dr. Prior says "from its corolla seen in profile being shaped like a bill-hook, and on the doctrine of signatures, supposed to heal wounds from edged tools."

(2) Common Bugle, Ajuga reptans.

Carrot Plant. A correspondent at Wells gives me this as a local name for the Eschscholtzia.

CART-WHEEL. A correspondent at shepton Mallet gives me this as a lceal name for the Hemlock, Conium maculatum.

Case-weed. Sheph $ә$ d's Purse, Capsella Bursapastoris, so called from its lit'le purse-like capsules, from Fr. caisse, Lat. capsa, a money-bcx.

CASE-TVORT. Same as CASE-TVEed.

CAssocks. Couch-grass, Triticum repens (S.W. Wiits, Somerset border).

CASs-tweed. Same as CASE-tweed.

CAstrags. A correspondent at Luppiti (Devon) gives this as a local name for SNAGS - the fruit of a Blackthorn, Prunus spinosa. Called in West Somerset Kestexs or Christians.

CAST THE SPEAr. Miss Ella Ford, of Melplash (Dorset) gives me this as a lecal name for the Golden Rod, Solidago virgaurea.

CATChFLY. A name originally given by Gerarde to. Silene armeria, but now applied to the genera Silene and Lychnis, including the Bladder Champion, White Champion, Ragged Robin, and others. The name is, however, chiefly given to species having sticky hairs, and Dr. Watson says it ought not be applied to any of the three species I have named. It is also given to other plants of which the stems or leaves are sticky, and particularly to the Sundew family, Drosera.

CATch. WeEd. (1) The Goose Grass or Cleavers, Galium Aparine, from its habit of catching the passer by.

(2) Several correspondents at Dunster give this as a local name for Madwort, which I think must be a mistake for Wild Madder, Rubia 
peregrina. The Madwort, Asperugo procumbems, is an alien, generally rare, but found near Bath, though not elsewhere in Somerset. The Wild Madder is very common in the neighbourhood of Dunster, and in an early stage much resembles the Goose-grass mentioned above. It is rery spiny, with short curved prickles, which would amply account for the local name.

CAT Hips. A correspondent at Stockland (Devon) gives this as a loc $x$ l name for the fruit of the Dog-rose, Rosa canina.

Cat Nep. Cat-mint or Cat-nip, Nepeta Cataria, from the fact that cats are very fond of it, and seem almost intoxicated by the smell of it.

Cat o' Nine Tatus. (1) Rev. Hilderic Friend gives this as a Devonshire name for the catkins of the Hazel, Corylus Avellana.

(2) The name is also given to the Great Reedmace, Typha latifolia. See CAT's TAIL (1).

Cat Posies. A correspondent at Rodden (near Frome) gives this as a local name for the Daisy, Bellis perennis.

Cats AND Dogs. Mr. Edward Vivian, of Trowbridge, gives me this as a local name for the blossom of the Willow, Salix.

Cats AND KeYs. Fruit of the Ash, Fraxinus excelsior, and Maple, Acer campestre. Rev. Hilderic Friend says "In Somersetshire the people speak of CATS AND KEYS."

CAT's CuAws. (1) Bird's-foot Trefoil, Lotus corniculatus.

(2) Kidney Vetch, Anthyllis Vulneraria.

(3) Bramble, Rubus fruticosus (Shoscombe).

CAT's EAR. The usual English name for several plants allied to the Hawkbits, particularly $H y p o c h a r i s$ radicata and $H$. maculata, from the shape of their leaves.

CAT's EARs. Corn Cockle, Lychnis Githago (Stour Provost, Dorset).

CAT's Eres. (1) A fairly general name for the Germander Speedwell, Veronica Chamaedrys, more often called BIRD's Eres.

(2) Water Violet, Hottonia palustris (Long Load).

(3) Herb Robert, Geranium Robertianum (Chettle, Dorset).

CAT's FACE. The Pansy, both wild and cultivated, Viola arvensis and $V$. tricolor.

Cat's Foot. (1) The Mountain Everlasting Gnaphalium dioica, from its soft flower heads.

(2) Also the Ground Ivy, Nepeta Glechoma, from the shape of its leaves.

CAT's Fur. A correspondent at Babcary gives me this as a local name for the Bedstraw, Galium (? verum). 
CAT's HEAD. A very large kind of apple, sweet and juicy, excellent for eider.-F. T. ELWORTHY.

CAT'S Love. Garden Valerian, Valeriana officinalis, on which cats like to roll (S:W. Wilts).

Cat's Mrik. Sun Spurge, Euphorbia Helioscopia, from its milky juice oozing in drops, as milk from the small teats of a cat. This milk is used for curing warts, and hence the plant and other Spurges are also known as WARTWEED or WARTWORT.

Cats' Paws. (1) A correspondent at Stratton-on-the-Fosse gives me this as a local name for the Meadow Vetchling, but I think it possible that she has named this plant in mistake for the Birds-foot Trefoil, Lotus corniculatus-an error' which is very frequently made.

(2) Catkins of Willow, Salix, while still young and downy (Deverill, Wilts).

Cat's TaIL. (1) A common name for the Great Reedmace, Typha latifolia, more often called Butrush.

(2) The Cornfield Hoisetail, Equisetum arvense, a troublesome weed to farmers and gardeners.

(3) The common Mare's Tail, Hippuris vulgaris; called by the Dutch Kattestail.

(4) The Crack Willow, Salix fragilis (West Somerset).

(5) The Rev. Hilderic Fıiend gives this as a Devonshire name for Amaranthus caudatus, popularly known as Love LIES BLEEDING or PRINCE'S FEATHER.

(6) Viper's Bugloss, Echium vulgare. See CAT'S TAILS.

Cat's TaIL Grass. Timothy Grass, Phleum pratense.

Cat's TaIls. (1) Catkins of Hazel, Willow, Alder, sé.

(2) Leaves of the Silverweed, Potentilla Anserina (Batcombe).

(3) A correspondent at Wambrook gives it as a local name for the Ribwort Plantain, Plantago lanceolata. See CAT's TAIL.

Cat's Whin. Rest Harrow, Ononis repens.

CATtikeyns. Fuit of the Ash, Fraxinus excelsior (North-West Wilts).

CAULIFLOWERS. A Taunton correspondent gives me this as a local name for the flowers of the Elder, Sambucus nigra.

CAx. Wild Carrot, Daucus Carota (Dorset). Such names as Caxes, Kecks, Kex, Gicksy, \&c., are given to the dry hollow stalks of various umbelliferous plants, and are also applied to the plants themselves. 
CAXLIES. Cow-par'snip, Heracleum Sphondylium (Otterford). See above.

Centaury. The true Centaury is the genus Centaurium (formerly named Erythroea) of the Gentian family, and bears rose-coloured flowers, but the name is very frequently applied to various Knapweeds, the Corn Bluebottle, and other flowers of the genus Centaurea.

Centry. Bog Pimpernel, Anagallis tenella. I have this name from Barford (Wilts), and Mr. W. S. Price, of Wellington, tells me that a field in Hemyock in which this plant is found is known as "Centry Meadow."

Chatrs and Tables. S sed of the Box, Buxus sempervirens (Muchelney).

Chalk Plant. Gypsophila paniculata, often called the GAUZE-FLOWER.

Changeables. The Hylrangea, $H$. hortensis

Change of the Weather. A correspondent at Babcary gives me this as a local nam? for the Scarlet Pimpernel, Anagallis arvensis.

Chariot AND Horses, Monkshood, Aconitum Napellus.

Charity. (1) A correspondent at West Bradley gives this as a local name for Honesty or Lunary, Lunaria biennis.

(2) A correspondent at Bloxworth (Dorset) gives it as a local nam? for Jacob's Ladder, Polemonium ccruleum.

CHARLOck. (1) A general name for Wild Mustard, Brassica auvensis.

(2) The Wild Radish, Raphanus Raphanistrum (Dorset).

(3) Many cthor weeds of arable land are locally and erroneously called "Charlock."

Chatterboxes. A correspondent at Hammoon (Dorset) gives me this as a local name for the Herb Robert, Geranium Robertianum.

Cheat. A very common name in Dorset for the Darnel, Lolium temulentum, or for the Wild Oat, Avena fatua, or Oats which from lack of soil or food or from other causes have degenerated into the wild form.

Cheddar Pink. Dianthus g'aucus, from the place of its growth on the cliffs of the famous Caeddar gorge.

Cheddies. Potatoes (East - Somerset).

CHEese AND BUTTER. A correspondent at IVinsham gives me this as a local name for the Lesser Cslandine, Ranunculus Ficaria. See ButTer AND ChEESE (2).

CHeEse-Bowls. An old nam apparently still used in many districts for the Field Poppy, 
Papaver Rhous. . Dr. Prior says "from the shape of the ripe capsule resembling that of round cheeses."

Cheese-Cakes. (1) Bird's-foot Trefoil, Lotus corniculatus.

(2) A correspondent at Ligh-on-Mendip gives it as a local name for the Kidney Vetch, Anthyllis Vulneraria.

Cheese Cups. A correspondent at Hatch Beauchamp gives this as a local name for the Lesser Celandine, Ranunculus Ficaria.

CheEse-Flower. Common Mallow, Malva sylvestris. Sэe Cheeses.

Cheese Rennet. Yellow Bedstraw, Galium verum, from the fact that it was formerly used to curdle milk for making cheese.

Chenses. The round flat seeds of the Common Mallow, Malva sylvestris. Children are fond of eating them when green and soft.

Chemises. Hedge Convolvulus or Greater Bindweed, Calystegia sepium.

Chequered LILY. The Snake's-head Fritillary, Fritillaria Meleagris.

Cherry BAy. (1) several ycung people at Paulton give this as a local name for the Laurel, Laurus nobilis.

(2) Mr. T. W. Cowan tells me the name is usually applied to the Portugal Laurel, Cerasis lusitanica.

Cherry Odds. Cherry stones, always.-F.T. ELWORTHY.

Cherry Pie. (1) A very general name for the Heliotrope, Heliotropium peruvianum; so called from its scent.

(2) Great Hairy Willow Herb, Epilobium hirsutum.

(3) All-heal, Valeriana officinalis (S.W. Wilts).

Chibbal, Chibble, or Chipple. A young onion with the green stalk attached. Frcm the Frerch Ciboule, derived from the Latin Cepulaa small onion. Mr, F. W. Mathews says the name "appears by tacit consent to be reseived for the immature spring-sown onion."

CHICK-CHAск. A South Somerset form of SHICK-SHACK - a name given to the leaves and "Apples" of the oak, worn on Royal Oak Day, May 29 th.

Chickens.-Rev. Hilderic Friend gives this as one of the Devonshire names for London Pride, Saxifraga umbrosa; probably a contraction of "Hen and Chickens."

CHICkWEed. (1) The usual English name for Stellaria media, whose bright green egg-shaped leaves and tiny white star-like flowers abound 
in neglected gardens practically oll the year through. One of the names by which our fathers called it was Hex's INHERITANCE.

(2) Mr. W. D. Miller tells me that the name is common to all the Cerastiums and Stellarias, and is applied more loosely still.

(3) A considerable number of my correspondents give the name to the common Groundsel, Senecio vulgaris, well known as a valuable food for birds.

(4) A correspondent at Axbridge gives it as a local neme-(Dr. Watson says a misncmer)for the Scarlet Pimpernel, Anagallis arvensis. Rev. Hilderic Friend says the Chickweed has in some cases been confused with the Pimpornel.

CHICory. A very general name for the beautiful blue Wild Succory, Cichorium Intybus.

Chilblain Berries. The scarlet egg-shaped berries of the Black Bryony, Tamus communis.

CHILDREx OF ISRAEL. (1) A common name for the Virginia Stock, Malcolmia maritima, on account of its numerous small flow is.

(2) In Wilts the name is given to a small sarden variet y of Campanula for the sams reason.

(3) Mr. Edward Vivian, of Trowbridge, tells me that a large number of people in that district give the name to the London Pride, Saxifraga rimbrosa.

Childrex's Clock. Dandelion, Taraxacum officinale. This p'ant is very commonly known by the name of "Clocks" from the fact that children pretend to tell the time by counting the number of pufis of breath required to blow away all the downy seeds from the ripe seed-head. I have only had the prefix "Caildren's" from Dunkerton.

Chuney Bell-Flower. Correspondents at Muchelney and Stoke St. Gregory give me this as a local name for a Campanula, which I believe to be Campanula pyramidalis.

Chrmex Smock. The Wood Anemone, Anemone nemorosa.

Chruney Sweep. (1) The Black-head Grass or Field Wood-1ush, Luzula campestris.

(2) Ribwort Plantain, Plantago lanceolata (East Snmerset).

(3) Hoary Plantain, $P$. media (Oakhill and South Petherton).

(4) Small Knapweed, Centaurea nigra (Mudf $\mathrm{r} \cdot(\mathrm{d})$.

(5) Several correspondents at $\mathbf{S}$ uth Petherton give this as the lceal name for Timcthy grass, Phleum pratense.

(6) Great Reed-nzce, 'Typha latifolia, more commonly called Butrush (Mells).

(7) Mr. H. A. Bending, of Shosenmbe, gives it as a local nome for the Sweet-seent ed Vernal-grass, Anthoxanthum odoratum. 
CHIMNEY SwEepers. Field Woodrush, Luzula campestris (N.W. Wilts).

ChImNex Sweeper's Brush. Great Reedmace, Typha latifolia, more cemmonly called BULRUSH.

Chinney Sweep's Brush. (1) Hoary Plantain or Iamb's 'Tongue, Plantago media (Batcombe).

(2) Blick Knapweed, Centairea nigra (Mudfor $(\mathrm{d})$.

Chinaman's Brefrches. Dicentra spectabilis, popularly known as the Bleeding Heart, Lady's Locket, Lyre-flower, Locks and Keys, and hy many ot her names.

ChInese LANTERN. (1) A very general name for th? Winter Cherry, Physalis Alkekengi: som times called Cape Gooseberry.

(2) A correspondent at Minehead gives this as a local name for the Herb Robert, Geranium Robertian'im.

Chiny (or Chinny) Oyster. A very common local corruption of the name China Aster.

Chippls-Eye. Mr. F. W. Mathews, of Bradford-on-Tone, writes $m$ : "By confusion. the Tripoli Onion is r ften eelled CHIPple-Eye."

Chipples. Same as ChibBles.

Chit Chat The Mountain Ash, Pyris Aucuparia (S.W. Wilts).

CHookr-pia. (1) A fairly general name in North and East Somerset for the Snapdragon, Antirrhinum majus.

(2) Correspondents at Winscombe tell me the name is there given to the Spotted Orchis, Orchis maculata, the Snapdiagon being known as the "Garden Chooky-pig."

Chopped EGGs. A correspondent at Rodden (rea: Frome) gives this as a local name for the Yellow Toadflax, Linaria vulgaris.

Christ AND the Apostles. A correspondent at Stockland (Devon) gives this as a local name for the Passion-flower, Passiflora ccrulea.

Christen. His Honour J. S. Udal gives this as a Dorset name for " a small kind of jlum." Compare the two following names.

Christians. Mr. F. W. Mathews, of Bradfordon-Tone, gives this as a local name for the Bullace, Prunus insititia. See above and below.

Christurngs. Rev. Hildeic Friend gives this as a Devonshire name for "a small sort of plum." Compare the two preceding names and CRISLING.

Christras. Holly, Ilex Aquifolium, particularly whon used for decorative purposes; but also applied to any evergreen used for Christmas or other decoration, whether holly, mistletoe, or others. 
Christmas Axthems. A very common play upon the name Chrysanthemums, sent me from many parts of the county.

Christuas Berry. Holly (West Somerset and Devon). See Christuas.

Christuas Candles. The flowers of the Horse (hestnut, Asculus Hippocastanum (Oakhill). See also Candues and Christaras 'Tree.

Christuas Rose. (1) Black Hellebore, Helleborus niger.

(2) A correspondent at Camerton gives it as a local nams for the Wild Aconite, Eranthis hyemalis.

Christmas-tree, (1) M[r. F. R. Summerhayes, of Milborne Port, gives this as a local name for the flower-spike of the Horse Chestnut, Esculus Hippocastanum. See CHRIstMas CANDLES.

(2) The name is also applied to the Auracaria imbricata (often grown as a pot plant).

Chucky Chense. The Common Mallow, Malva sylvestris. See Chenses.

Chucky Pig. (1) Same as Chooky-pig (1).

(2) A correspondent at Cross (near Axbridge) gives it as a local name for the Grape Hyacinth, Muscari.

Church Belds. (1) Common Comfrey, Symphytum officinale.

(2) Canterbury Bells, Campanula Medium.

(3) A correspondent at Leigh (Dorset) applies the name to the Ivy-leaved Bell-flower, Campanula hederacea.

Ghurch Brooms. The Teasel, Dipsacus sylvestris.

Church Steeples. A name sometimes given to the Common Agrimony, Agrimonia Eupatoria.

Church-wort. An old name for the Pennyroyal, Mentha Pulegium.

UHURCHYARD ELDER. A Dunster correspondent gives me this as a local name for the Shepherd's Purse, Capsella B:irsa-pastoris.

Churchyan's Greeting. Dr. Downes ir forms me thit in the neighbourhood cf Ilminster, the Mistletoe, Viscum album, is sometimes called by this name.

Cigar Flower. - The general Englich nam? of a M xican plent of the Loosestrife family cultivated in Euglish girdens, Cuphea platycentra. It has a scarlet tubular corolla tipped with white and black.

Cladden. A name very common in Dorset for the Goosegrass or Cleavers, Galium Aparine, which is known by a large number of different names, of which about 20 commence with the letters CL. Mr. Mansell Pleyilell spells the name Cllaiton. 


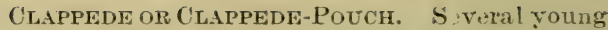
people at Aller give me this as a local nam for the Shepherd's Paise, Capsella Bursa-pastoris. If the name is still used in that neighbourhood it is most interesting. Dr. Prior gives the following particulars with regerd to it:-" $\Lambda$ aicknam? from the Dutch. which alludes to the licensed begging of lepers, who stood at the crossways with a bell and clapper." Hollman von Fallersleben, in his Nierlerländische Vo.kslieder, says of them (p. 97) : - "S sparated from all the woild, without house or home, the lepers were obliged to dwell in a solitary wretched hut by the roadside: their clothing so scanty that they often had nothing to wear but a hat and a cloak and a begging wallet. They would call the attention of the passers-by with a bell or a clapper, and receive their alms in a cup or a bason at the end of a long pole. The bell was usually of brass. The clapper is described as an instrument made of two or three boards, by rattling which they excited people to relieve them. The lepers would get the name of Rattlo-pouches, and this be extended to the plant in allusion to the little purses which it hang; out by the wayside.'

Clary. A very general name for the Wild Sage, Salvia Verbenaca. The usual English rame for S. Sclarea. See Clear Exe.

Claton. Sce Claden.

Claut. The Marsh Marigold, Caltha palustris (N.W. Wilts).

Clavers. A Dorset form of the name Cleavers (given by Rev. W. BARNes and others). See Claden.

Clay. A correspondent at Washford gives me this as a local name for the Goosegrass or Cleavers. See Claden.

Clayton. See Claden.

Clear Exe. (1) Wild Sage, Salvia Verbenaca. The old herbalists considered this one of the most efficacious of herbs in any complaint of the eye. Its seeds when put into water yield a mucilage which, placed within the cyelid for a few minutes, envelops any particle of dust which may pain the eye. Hence the name of the plant Clesi Eye or Clary.

(2) I am indebted to Mr. T. W. Cowan for the following interesting notes:-CLEAR-EYE or SEE-BRIGHT are old popular names for the plant Salvia Sclarea, and are corruptions of the word Clary, otherwise called Godes-eie or Oculus Christi. On the strength of these names it was regarded, Prior says, as a proper ingredient for eye-salves. Gerard says in his Herbal it is called Clarie or Cleere-eie. See also GooDr's-EYE, Somerset name for Salvia Sclarea, a corruption of a popular name GOD'S-EYE (Britten \& Holland). 
Godes-eie, Christ's-exe, and Clear-eye seem free renderings of its Low Latin name Sclarea (from clarus).",

Cleavers (1) Goose-grass, Galium Aparine. See Cladex. The name is, of course, due to the way in which the hooked seeds and leaves of the plant cling to the clothes of persons or to the coats of animels coming into contact with them.

(2) Correspondents at Oakhill apply the name for the same reason to the Burdock, Arctium majus, and

(3) For reasons which are not so obvious to the Teasel, Dipsacus sylvestris. Dr. Wa'son tells me that the flower heads of the Fuller's Teasel are hooked as in the Burdock. Those of the Wild Teasel are sharply pointed. In his opinion the name ought to be restricted to the Goose-grass.

Cleeve-Pink or Cliff-Pink. A species of pink which grows wild in the $\mathrm{c}$ annies of Cheddar Clifis, having a fine scent, more generally known as Cheddar Pink, Dianthus glaucus. Cleve for cliff is common in early English.

Cletheren. Goosegrass or Cleavers, Gatium. Aparine (East Somerset).

Cliddex, Clide, Clider, or Clidons. Goosegress, as above. See Cladir.

Cliff-Rose. Thrift or Sea-Pink, Armeria maritima, on account of its love for our seaside elift's and rocks and its rose-coloured flowers.

Clinisixg Jacks. Nasturtium:, Tropaolum majus (Evorcieech).

Clinf. Goosegrass or Cleav $\mathrm{rs}$, Galium Aparine (Paulton).

Clinging Sweethearts. Goosegrass, as above (Shiewton, Wilts).

Cling Rascal. Rev. Hilderic Friend gives this as a Devonshire name for the Goosegrass, on the authority of Britten, p. 107.

Clitch Buttox. Rev. Hilderic Friend also gives this as a Devonshire name for the Goosegrass.

Cimte or Clithe. Mr. T. W. Cowan gives me this as an old name for the Burdock, Arctium majus.

Curtes. A Wiltchire name for the Goosegrass.

Curvers. A Somerset and Dorset name for the Goosegrass.

Clock-Flower. The Dandelion, T'araxacum officinale. See Clocks.

Clocks. (1) A very general naine for the light seed heads of the Dandelion, which the children blow upon, to tell the hour by the number of puffs required to blow off all the seeds. 
(2) The seed-heads of other ralatives of the Dandelion, e.g., Groundsel, Coltsfoot, \&e.

Clocks and Watches. Dandelion, Taraxacum officinale (Wells).

Clog WeEd. Mr. T. W. Cowan gives me this as a Somersetshire name for the Cow-Parsnip, Heracleum Sphondylium, and tells me that it is a shortened form of Keyc-logge, i.e., Keck-lock (A.S. leac) or Kex-plant (Prior).

Clot Bur. (1) Burdock, Aretium mrjus.

(2) Mr. T. W. Cowan gives me this as a local name for the Agrimony, Agrimonia Eupatoria. See COCKLE-BUR.

Clote. Yellow Water Lily, Nymphoa lutea. (East Somerset and Dorset.)

Clothes Brush. Wild Teasel, Dipsacus sylvestris (S.W. Wilts).

Clothes Pegs. (1) Early Purple Orchis, Orchis mascula (Bradford-on-Tone and Asheott).

(2) A correspondent at Netherbury (Dorset) gives it as a local name for the Foxglove, Digitalis purpurea.

Cloud BERRy. (1) A general name for the Mountain Raspberry, Rubus Chamamorus, so called, Gerard says, because they grow on the summits of mountains, "where the cloudes are lower then the tops of the same all winter long, whereupon the people of the countrie haue called them Cloud-berries." Mr. T. W. Cowan suggests that possibly they get thoir name from old English clud=a cliff. This plant does not grow in Somerset, and the name is given in some parts of that county and of Dorset, to

(2) the Dewberry, R'bus cusive, which Dr. Watson says has no right to the name.

Crove Gilatwfur (or Gilliflower). Clove pink, Carnation, Dianthus Caryophyllys. See GILAwFEr and GILLIFLowER.

Clover Devil. The Dodder, Cuscuta.

Clutch. Knot-grass, Polygonum aviculare known also in West Somerset as TACKER-GRAsS TUCKER-GRASS, and MAN-TIE.

Cly, or Clyde. Goose-grass or Cleavers. Galium Aparine (West Somerset and Devon).

CuY-Burs. The little hooked seed pods of the Goosegrass, as above.

Clyder, Crydern, or Clyther. A name used, throughout a great part of the four counties, for the Goosegrass, as above.

COACH AND Horses. M[nkshond, Aconitum Napellus (Sherborne). Compare CHARIOT AND Horses.

CoAch Horses. Irr. F. 'T. Elworthy gives this ass a West Somerset name for the common Pansy, Viola tricolor (cultivated) or $V$. arvensis (wild). 
Coachman's Butrons. The Field Scalious, Scabiosa arvensis (Queen Camel).

CobBler's WAX. Several correspondents at Donhead (Wilts) give me this as a local name for the Sumach, Rhus.

СоB-IVEB. A correspondent at Broadstone (Dorset) gives me this as a local name for the Houseleek, Sempervivum tectorum. The name is probably due in some measure to the fact that there is a closely related plant, grown in gardens, known as the Cobweb House-leek, Sempervivum arachnoideum, on account of the long white hairs at the tips of the leaves, which cross and present the appearance of a plant over which a spicler has trailed its net.

COCKAGEE ( $g$ hard). A kind of small hard sou. cider apple, in use in the West of Englandr. (Jenvings, and Wilts.)

Cock Grass. (1) Ribwort Plantain. Plantago lanceolata. Mr. Elworthy says : "The only name used by farmers for this, the commonest variety of the Plantains" (West Somerset).

(2) Perennial Rye-grass or Red Darnel, Lolium perenne. Children, taking a blade in one hand, run up the sprouts on each side with the finger and thumb of the other hand, and boys say, "What shall I be?" and girls "Who shall I marry?"

A tinker? a tailor?

A soldier? a sailor?

A rich man? a poor man?

A 'pothecary? a thief ?

(PulMan).

Many other questions are asked and answered by Somerset boys and girls in the same way. I do not think it necessary to set out all the forms in detail in this list, but the following selection, kindly sent me by Dr. Watson, will give a fair idea of the lines on which th $y$ run :The usual rendering is "Tinker, tailor, soldier, sailor, rich man, poor-man, beggar-m»n, thief." About Culmhead the last two are replaced by "gentleman, farmer." Other renderings are to live in a "big-house, little-house, pig-sty, barn," to be married in "silk, satin, cotton, rag"; to go to church in a "coach, carriage, wheelbarrow, mud-cart" ; to be married "this year, next year, sometime, never."

Cockle Butrons. The seed-head of the Burdock, Arctium majus. One of our Somerset names for the Burdock is "Cuckold," of which "Cockle" is a corruption.

CockLe-BUR or CLOT-BUR. Mr. T. W. Corwan gives me this as a local name for the Agrimony, Agrimonia Eupatoria. See also CLOT-BUR.

CocKr.Es. (1) Periwinkle, Vinca major (and $V$. minor). Rev. Hilderic Friend attempts to 
explain this name by suggesting a confusion between two kinds of shell-fish on the part of people living far from the sea and not knowing the difference between the two. I have had this name sent me from several different parts of South Somerset.

(2) A general name throughout the district for the seed-hoads or burs of the Burdock, Arctium majus.

(3) A correspondent at Watchet gives this as a local name for the flowers of the Bird's-foot Trefoil, Lotus comiculatus, and also for

(4) The seeds of the Furze, Ulex europaus.

(5) The Corn Cockle, Lychnis Githago.

(6) Fircones (Leigh, Dorset).

Cockle Shells. Several correspondents at South Petherton give me this as a local name for the Periwinkle, Vinea.

Cock RoBIs. (1) The common name for the Red Campion, Lychnis dioica, in North Somerset.

(2) Several correspondents at Miells give this as a local name for the Ragged Robin, Lychnis Flos-cuculi.

Cocks AxD Hexs. A common name for the Ribwort Plantain, Plantago lanceolata:

Cock's Cour. A name given to several different flowers, but most generally to the (1) Yellow Rattle, Rhinanthus Crista-galli. The latter name is Latin for Cock's Comb, and is given on account of the shape of the calyx. The plant bears an equivalent name in many of the countries of Europe.

(2) The Lousewort, or Red Rattle, Pedicularis sylvatica.

(3) Several correspondents at Puddletown (Dorset) give it as a local name for the Teasel, Dipsacus sylvestris.

(4) The Cock's Comb of the gardeners is Celosia cristata, of the Amaranth family.

(5) Often given to another member of the same family-Love Lies Bleeding, Amaranthus caudatus A. riber or A. melancholicus.

(6) A correspondent at Compton (between Yeovil and Sherborne) gives it as a local name for the Calceolaria.

Cock's HEAD. 'The Sainfoin, Onobrychis viciafolia, from the shape of the legume.

Cocks' HEADs. The heads of the Ribwort Plantain, Plantago lanceolata, which contain the seeds. Holloway says :- "In West Sussex boys play with these heads; one holds a stalk in his hand while another with a similar stalk strikes his opponent's, and which ever loses the head first is conquered. It is called 'Fighting Oocks.' "

Cockspur (1) An English name for the Virginia Hawthorn, Cratcegus virginica.

(2) Several correspondents at Bradford-onTone give this as a local name for Crow's-foot ? 
Cock Thistue. A correspondent at Hammoon (Dorset) gives this as a local name for the Scotch (or Cotton) Thistle, Onopordum Acunthium.

Cock Upon Perch. A correspondent at West Bradley gives this as a local name for "Eggs and Bacon." I balieve the name is applied both to the Yellow Toadflax, Linaria vulgaris, and the Bird's-foot Trefoil, Lotus corniculatus.

CockWEED. Several correspondents in the neighbourhood of Axminster give this as a local name for the Pepperwort, Lepidium.

Cocon Buttons. The Burdock, Aretium majus (Queen Camel). Evidently a corruption of "Cuckold."

Codurns And Creajr. (1) A very general name for the Great Hairy Willow-herb, Epilobium hirs:tum ; from the odour of its flowers or of its fresh shoots, when crushed in the hand.

(2) A well-informed correspondent at Martock gives this as a local name for the Narcissus.

COE Grass. Juncus bufonius, the grass which is said to be the cause of the coe in sheep and cattle. By some this disease is said to come from the Goosegrass-Carex hirta-but boih are generally found growing either together or in similar wet land. (F. T. Elworthy.)

COFfee Flowers. A correspondent at Ilminster gives this as a local name for the Comfrey, Symphytum officinale.

CoG WeEd. A correspondent at Curry Mallet gives this as the local name for a yellow flower, very common in that district, having its fruit in spiral cogs. From this description several botanical friends have recognised the plant as the Spotted Medick, Medicago maculata, or the Toothed Medick, $M$. denticulata.

Colewort. (1) Several correspondents give this as a name for Avens, Geum urbanum.

(2) It is also applied to the Sea Cabbage, Brassica oleracea.

Colt's TaIL. Rev. Hilderic Friend gives this as a Devonshire name for (1) The Cornfield Horsetail, Equisetum arvense ; and

(2) Common Mare's tail, Hippuris vulgaris.

Comb AND BRUsh. Wild Teasel, Dipsacus sylvestris (S.W. Wilts).

Comb Fery. The Hard Fern, Blechnum Spicant (Dulverton).

Combs AND Hampins. A Taunton correspondent gives this as a local name for the Dandejion, Taraxacum officinale.

CoNFETTI. A correspondent at Watchet gives this as a local name for (1) White Goosefoot or Fat-hen, Chenopodium album; and 
(2) The seeds of the Dock, probably applied to more than one spccies, but particularly to the Great Water Dock, Rumex Hydrolapathum; very common on banks of streams and rivers and on peat moors.

Conker Berries. The ripe fruit or "hips" of the Wild Rose, Rosa canina (East Somerset and Dorset).

Conkers. (1) The fruit of the Horse Chestnut, Asculus Hippocastanum ; from a game played by boys who string the horse-chestnuts on cord and take it in turn to strike at each other's rut in order to "conquer" by cracking it.

(2) A Watchet correspondent gives this as a local name for the Ribwort or Lamb's 'Tongue Plantain, Plantago lanceolata, for a reason which will be found under Cock's HEADS.

(3) The ripe fruit or " hip " of the Wild Rose.

(4) The bedegu2r, or gall known as the "Robin's Pincushion " oiten found on the Wild Rose. See CANKER.

Conquer Moors. The Dandelion, Traraxacum officinale (Beaminster district).

Conqueror Flowers. See Conkers.

Convict Grass. Mr. Harry Pouncy tells me that at Portland the Red Valerian, Kentranthris ruber is known by this name.

Cop-Rose or Copper Rose. The Field Poppy, Papaver Rhoeas, from its red rose-like flower and the cop or button-shape of its capsule. Dr. Downes kindly reminds me that Cop is A.S. for Head, c.f. modern German Kopf.

CoRn Bottle. A Devonshire form of the name Cornflower or Bluebottle, Centaurea Cyanus.

CORN COckLE. Several correspondents at Winsham give this as a local name for the Black Knapweed, Centaurea nigra. The true C m Cockle is Lychnis Githago, and the application of the name to the Knapweed is due to a double confusion.

CoRNeTs. A correspondent at Whitchurch Canonicorum (Dorset) gives this as a local name for the Rest Harrow, Ononis repens.

Corn Flag (1) Yellow Iris, Iris Pseudacorus. (2) Any plant of the genus Gladiolus.

CORNFLOWER. (1) A very general name for the Bluebottle, Centaurea Cyanus.

(2) Applied almost as freely to the Greater Knapweed, Centaurea Scabiosa.

(3) Field Scabious, Scabiosa arvensis.

(4) A correspondent at. Widworthy (Devon) gives it as a local name for the Common Red Poppy, Papaver Rhocas.

Corn Pop. Bladder Campion, Silene latifolia (N.W. Wilts). 
CoRy Rose. A fairly general name for the Common Red Poppy, Papaver Rhocas.

Convwood. Miss Ella Ford, of Melplash (Dorset), gives me this as a local name for the Cornel or Dogwood, Cornus sanguinea.

Cotтon Flower. Several correspondents at Horton and Wellington give this as a local name for the Plantain-probably Plantago media, from the general cottony appearance of its spike.

Cotton IVeed. (1) An old name for the Highland Gudweed, Gnaphalium sylvaticum, from its soft white pubescence.

(2) Mountain Everlasting, or Cat's-foot, Antennaria dioica.

Couch (1) The local form of Couch-grass or Cou 'h-wheat. Triticum repens; a very troublesome weed. Mr. T. W. Cowan wites :- "A corruption of Quitch-or Quick-grass. A. Sax. cwice, quice, i.e. the quick or vivacious plant. In Lincolnshire Wicks (from wick-alive), it being very tenacious of life, and to its habit of growth lying on the ground. Doiset Cooch to lie, French coucher." See Twiтch.

(2) Other troublesome weeds (e.g. the Field Gonvolvulus) are often known as Couch or CоOCH.

Cough Wort. The Coltsfoot, Tussilago. Farfara, from its medicinal use for the cure of coughs.

CoURtship AND MATRIMony. Meadowsweet, Spircea Ulmaria.

"Coventry Bells. (1) Any of the cultivated "Canterbury Bells," particularly Campanula Medium.

(2) A correspondent at Sherborne gives this as a local name for the Foxglove, Digitalis purpurea.

Cowbane. A general name for the Water Hemlock, Cicuta virosa, from its injurious effect upon cows. Dr. Downes writes me:-Cicuta virosa is a very rare plant in Somerset; more probably the plant referred to is Enanthe crocata, the Hemlock Water-Dropwort. I an told that cows have died from eating the roots of this plant after ditches have been cleaned out and the roots left on the ground. The stems and leaves do not seem to be so injurious."

CotvBel. A well-informed correspondent at Allerford gives me this as a local name for the Bladder Campion, Silene Cucubalus.

Cow BeLry. Several correspondents at Muchelney give me this as a local name for Cowparsnip, Heracleum Sphondylium. "Bəlly" is possibly a corruption of "Billers," which see.

COWBERRY. (1) The Red Whortleberry, Vaccinium Vitis-Idcea. Dr. Prior says "apparently 
a blunder between Vaccinium, the fiuit of the Whortle, and Vaccinus, what belongs to a cow." Although this name has been sent me by a number of correspondents I und erstand this particular Whortleberry is very rare in Somerset, and is only found wild on the Quant cks, n 'ar Q iantoxhead.

(2) Mr. F. W. Mathews tils me that near Dunster the common Whotleberiy, Vaccinium Myrtellus, is called Comberry. $\mathrm{H}_{3}$ adds that cows are ver'y fond of the fruit and bush, but that it do:s not agree with them if eaten in any quantity.

Cow Bumble. The Cow-parsnip or Hogweed, Heracleum Sphondylium (Otterford).

Oow Chervil. Wild Beaked Parsley, Anthriscus sylvestris. Called "Rat's bane" in. West Somerset; a favourite food of pet rabbits. It grows three or four feet in height, and is the first of our umbellife: ous plants to flower in the spring.

Corv-FLop. (1) A common name in West Somerset and Devon for the Foxglove, Digitalis purpurea.

(2) Several correspondents at Dunster give it as a local name for the Cowslip, Primula veris.

(3) Rev. Hilderic Friend says the name is given by farmers to a species of wide spreading oat to distinguish it from the Tartarian oat.

Cow Grass. folium medism.

(2) The perennial form of Red Clover, Trifolium pratense.

Cow Parsley. (1) Fool's Parsley, Ethusa Cynapium (East Somerset). Anne Pratt records : "Some years ago two ladies in Somersetshire, who ate it in salad, suffered very seriously, though both ultimately recovered."

(2) Dr. Watson tells me that in the Taunton district this name is given to the Wild Beaked Parsley, Anthriscus sylvestris, and probably to other similar-looking membars of the Parslet family.

Cow QUakes. A comespondent at Compton (between Yeovil and Sherborne) gives $m$ ? this as a local name for the Quaking Grass, Briza media.

Corvs AND Butus. The Wild Arum or Cuckoopint. See Cows and Calves.

Cows AND CaLves. (1) A very general name for the Wild Arum or Cuckoo-pint, Arum maculatum. Those flowers in which the spadix is very light in colour are called "Calves"; those in which it is medium coloured are "Cows" ; and those in which it is very dark "Bulls."

(2) A correspondent at Leigh (Dorset) tells me in that district the name is given to Pink and White Clover. 
Cows, Catave, ANo Bulls. A form of the nam? Cows AND Calves, sent me from Paulton.

Cow's EYes. The Ox-eye, Chrysanthemum Leucunthem:um (S'sexey's School).

Cowslip. (1) This is the general English name for Primula veris, but the Rev. Hilderic Friend gives it as a Devonshire name for the Foxglove, Digitalis purpurea; and also for

(2) Bittercup;, in the neighbourhood of Teignmouth.

Mr. T. W. Coran tells me that the name Cowslip is considered to be a corruption of Keslop or Keslip, A. Sax. ceselib, cyselib, i.e. the prepared stomach of a calf (which the plant was supposed to resemble) used as rennet for making cheese.

Cowscrp of BedLAM. A name given by Mr. F. T. Elworthy in his West Somerset Word Book to the Common Lungwort, Pulmonaria officinalis, much used as a herb, and known also as Jerusalem Cowslip or Jerusalem Seeds. Mr. T. W. Cowan tells me that in other places the plant is known as BeDLAM Cowslip, and that this name is also given to the Paigle or larger Cowslip, Primula veris.

Cow's PARsLex. A correspondent at Batcombe gives me this as a local name for the Vileriar. He does not indicate the species, but Dr. Downes suggests it is probably Valeriana Sambucifolia. Size also Cow PARsLEY.

Cow's PARswip. This was sent me from Oakhill as a lccal name for the Wild Arum or Cuckoo-pint, Arum maculatum, but the name seemed to me so improbable that I wrote for further information to the Schoolmaster, Mr. R. A. Colville, who kindly replied that the plant is astually known by this name in that district.

Cow's THIstur. A correspondent at Watchet gives me this as a local name for the Creeping Thistle, Cnicus arvensis; sometimes known as the Horse Thistle.

Cow Thistuf. A correspondent at Batcombe gives this form of the name for the plant referred to in the $\mathrm{p}$ 'evious paragraph.

COW WEED. (1) Several correspondents in the neighbourhood of Axminster give me this as a losal name for the Chervil, Charophyllum temulum.

(2) Same as Cow Wheat, which see.

Cow WHEAT. (1) In the Axminster district this name would appear to be frequently given to the Yellow Rattle, Rhinanthus Crista-galli, and the name YELLOW R.ATTLE to be.frequently giren to the true Cow Wheat, Melampyrum cristatum and $M$. pratense.

(2) Mr. T. W. Cowan tells me that in some 
places this name is given to the Horse-flower or Lesser-flowered Yellow Cow-wheat, Melampyrum sylvaticum.

Crab's Claw. (1) The Water-Soldier, Stratiotes Aloides.

(2) Spotted Persicaria or Red-legs, Polygonum Persicaria.

Crack Nut. Rev. Hilderic Friend gives this as a Devonshire name for the fruit of the Hazel, Corylus Avellana.

Crammick. Rest Harrow, Ononis repens (East and Mid-Somerset).

Crane Bill. A corcespondent at Hatch Beauchamp gives me this as a local name for the Iris-also known in the samelocality, as DuCK'sBILL.

Crannock. A correspondent at Keinton Mandeville gives me this as a local name for the Furze or Gorse, Ulex europaus.

Cratwlers. A correspondent at Stalbridge gives me this as a local name for Scurvy Grass, Cochlearia officinalis. Dr. Downes points out that this is a maritime plant, very rarely found inland, and it is improbable that it grows at Stalbridge.

Crazy. (1) A name applied in North Somerset and Wilts to Buttercups in general. A correspondent at Doshead (Wilts) tells me that certain fields in that district are said to be "smothered in Crazies."

(2) The Marsh Marigold, Caltha palustris.

(3) A correspondent at Frome gives it as a name for the Yellow Water Lily, Nymphoea lutea. Dr. Prior says "A Apparently a conruption of CHrIST's EYE, Lat. oculus Christi the medieval name of the Marigold, whish, through the confusion among old write:s betweer Caltha and Calendula, has been transferred to the Marsh Marigold and thence to other Ranunculacece."

CraZY BeTt. (1) The general 1 ame all over Wilts for the Marsh Marigold, Caltha palustris.

(2) Applied also in S.W. Wilts to various Bittercups and to the Lesser Celardine, Ranunculus Ficaria.

(3) Ox-eye Daisy, Chrysanthemum Leucanthemum (Hampuworth, Wilts).

(4) A ccrrespondent at Tatrorth gives it as a local name for the IVater Lily, Nymphou lutea.

Crazy Betsey. Marsh Marimold, Caltha palustris (Little Largford, $\Pi$ ilts).

Crazy Cup. A correspondent at Chew Magna. gives me this as a local name for the Lesser Celandine, Ranunculus Ficaria.

Crazy Linies. A correspondent at Batcombe (Dorset) gives me this as a local name for the Marsh Marigold, Caltha palustris. 
Crazy Mar. Any kind of Buttereup (N.W. Wilts).

Crazy MoIr. Creeping Buttercup, Ranunculus repens (N.W. Wilts).

Cream AND BUtTer. A correspondent at Upottery gives this as a local name for the Lesser Celandine, Ranunculus Ficaria.

Creed. Lesser Duckweed, Lemna minor (N.W. Wilts).

CREEPER. $\Lambda$ correspondent at Watchet gives me this as a local name for Meadow Barley, Hordeum nodosum.

Creeping Charlie. A Devonshire name for the Biting Stonecrop, Sedum acre.

Creeping Grass. (1) Meadow Barley, Hordeum nodosum (Bradford-on-Tone).

(2) Barren Brome-grass, Bromus sterilis (South Petherton).

Creeping JACK. Biting Stonecrop, Sedum acre.

Crefeping Jennie. A name given to a variety of plants, but most commonly in Somerset to

(1) Moneywort, Lysimachia Nummularia, known also as the Creeping Loosestrife or Herb Twopence; often cultivated as a rockery plant for its trailing bran shes, covered with shining deep green leaves and handsome flowers of bright yellow.

(2) Biting Stonecrop, Sedum acre.

(3) Ground Iry, Nepeta hederacea (South Petherton and Combe St. Nicholas).

(4) Ivy-leaved Toadflax, Linaria Cymbalaria.

(5) The name is also given to the Common Yellow Loosestripe, Lysimachia vulgaris.

(6) Creeping Cinquefoil, Potentilla reptans (Westonzoyland).

(7) A correspondent at Winsham tells me the name is sometimes given in that district to the Bindweed, Convolvulus.

(8) A correspondent at Wircanton gives it as a local name for the Yellow Bedstraw, Galium verum.

(9) A number of correspondents in the neighbourhood of Axminster give it as a local name for the Virginia Creeper, Ampelopsis quinquefolia.

Creepixg SaILor. (1) Ivy-leaved Toadflax, Linaria Cymbalaria.

(2) Same as Aaron's Beard (2).

Creepixg Saxifrage. Same as Aaron's BEARD (2).

CreEse. A very common name for Water Cress, Nasturtium aquaticum.

Crewer. A very general name throughout a great part of the district for the Cowslip, Primula veris. 
CREWRERNE BoYs. Several correspondents at Winsham apply this name to various kinds of Thistles, naming particularly the Marsh Plume, Cnicus palustris, and the Scotch, Onopordum Acanthium, the latter of which does not, however, grow wild in the neighbourhood.

CREWKERNE WARRIORS. A Taunton correspondent gives me this name for Thistles, as above.

Cribbles. Onions grown from bulbs (S.W. Wilts, Somerset border).

Crinisox Lady. A correspondent at Evercreech gives this as a local name for the Carnation, Dianthus Caryophyllus.

Cremsons. Mir. Edward Vivian, of Trowbridge, gives me this as a local name for Tenweek Stocks, Matthiola annua, no matter of what colour. The name is used indiscriminately, just as we say "Pinks," even of white ones.

ComINCHLING. Holloway, in his Dictionary of Provincialisms, gives this as a Glodcestershire name for "A small apple stich as can be easily scranched between the teeth."

Crinoline. A correspondent at Martock gives me this as a local name for the Fuchsia.

C'RISLING. (1) A small, black, very sour wild plum (F. 'T. Elworthy).

(2) A small shrivelled immature apple (F. 'T. Elworthy).

Cristex. A small kind of plum (Barnes). See Christen.

Crocks Axd Kettues. The seeds of the Box, Buxus sempervirens (South Petherton and Evershot). I understand a game is played with these seeds in some of our villages, but do not know what form the game takes.

Crocodile. Rev. Hilderic Friend says the small variety of Holly which grows in hedgerows, and is exceedingly brittle, chiefly bears this name, whish is common in Somerset, Ilex Aquifolium.

Crocus Japonica. A Somersetshire corruption of Corchorus japonica, now known as Kerria japonica, a shrub which bears orange-coloured blossoms; also known as Summer Roses.

Cross Flower. (1) Milkwort, Polygala vulgaris (West Somerset). Dr. Prior says "from it s flowering in Cross-week."

(2) A correspondent at Hatch Beauchamp gives this as a local name for the Wallflower, Cheiranthus Cheiri, which may owe the name to the fact that (being one of the Cruciferce) its four petals are arranged in the form of a cross.

CRow Berls. Wild Hyacinth or Bluebell, Scilla non-scripta (S.W. Wilts, Hants boride"). 
Crowdy KIT. Wate" Figwor, Scrophrlaria aquatica. "Crowdy" is an old na me for a fiddle, and this plant is frequently called "Fiddles" or "Fiddlestrings" in Somerset. for the reason that children strip the stems of their leaves and scrape them across each other, fiddle-fashion, when they produce a squeaking noise. Dr. Watson tells me the same name is used in the North.

Crowdy Kit o' the WaLI. An old Devonshire name for Sedum acre and other varieties of Stonecrop.

Crowfeet. A Watchet correspondent gives this as a local name for the Lesser Spearwort, Rananculus Flammula, which is, of course, one of the Crowfoot tribe.

Crow Flower. Same as Crow Bell.

Crowfoot. (1) A general name for any flower of the Buttercup family.

(2) Bird's-foot Trefoil, Lotus corniculatus.

(3) A Martock correspondent gives this as a local name for the Musk, Mimulus moschatus.

Crow NeEdle. A correspondent at Leigh (Dorset) gives this as a local name for the Shepherd's Needle, Scandix Pecten-Veneris. See Crow's NeEdLe.

Crown of THE FIELd. Corn Ceckle, Lychnis Githago.

CRowx of Thorss. (1) A correspondent at Babeary gives this as local name for the Mredick" (? Medgehog Medick, Medicago intertexta, frequently grown in gardens). Mr. T. W. Cowan tells me that Medicago Echinus, or Calvary Clover, is called Crown of Thorns, but is not a native plant.

(2) A correspondent at Bloxworth (Dorset) gives it as a local name for the Passion Flower, Passiflora carulea.

(3) A correspondent at Stour Provost (Dorset) gives it as a local name for Nigella damascena, generally known as "Love in a Mist."

Crowpeck. (1) Shepherd's Needle, Scandix Pecten-Veneris. wilts).

(2) Corn Crowtoot, Ranunculus arvensis (N.W

Crows. A correspondent at Furley gives me this as a local name fo" the Cowslip, Primula veris.

Crow's Flower. Spotted O"chis, Orchis maculata (Sampford Arundel).

Crow's Foot. (1) Several correspondents at Chew Magna give this as a local name for the Coltsfoot, Tussilago Farfara.

(2) A correspondent at Charlton Herethorne gir es it as a local name for the Greater Stit chwort, Stellaria Holostea.

Crow's Legs. Wild Hyacinth or Bluebell, Scilla non-scripta (Zeals, Wilts). 
Crow's NeEdLe. A correspondent at Sampford Ai undel gives this as a local name for the Shephesd's Needle, Scandix Pecten-Veneris. See Crow NEFDLE.

Crow's Toes. Bird's-foot Trefoil, Lotus corniculatus.

Crucifix Flower. A correspondent at Hawkchurch (Devon) gives this as a local name for the Wallflower, Cheiranthus Cheiri. See Cross Frower (2).

Cruel. See Crewel.

Crumple Lily. A Devonshire name for Lilium Martagon and $L$. tigrinum, on account of their pretty habit of turning bask the petals.

Crumplixg. A general West of Fingland name for a small stunted apple; one which shrivels on the tree.

CRY BABY. (1) A common name in the Taunton district and in East Devor for the Herb Robert, Geranium Robertianum.

(2) Several correspondents at simpford Arundel give this as a local name fo: the Scarlet Pimpernel, Anagallis ariensis.

(3) Mrs. Day, of North Petherton, gives it ay a local name for the Rose Bay Willow Herbs Epilobium ang:stifolium.

Cry Baby Crab. A correspondent at Culmhearl gives this as the local form of Cry Baby (1).

Cuckle ButTons. A Devonshire name for the fruits or burrs of the Burdock, Arctium majus.

CuckJ.es. The East Somerset and Dorset name for the fruits of the Burdock, as above.

CuCKOLD. The Burdock, Arctium majus.

Cuckold Butroxs. The buirs of the Burdock, as above.

Cuckold Dock. The Burdock, as abore. (West Somerset).

Cuckoo or Cuckoos. Used in many cases as a contraction of CUCKOo FLOwER, which see.

(1) I have this shortened form from sereral districts as a local name for the Early Purple Orshis, Orchis mascula.

(2) Correspondents at Oa! hill and in several parts of Wilts give it as a local name for the Wood Anemone, Anemone nemorosa.

(3) Correspondents at Paulton give it as a local name for the Lady's Smock or Bitter-cress (generally known as the Cuckoo Flower), and in connection with this name it is interesting to note that the authors of the II iltshire Glossary state that about Sulisbury Saxifraga gramulata is knowil as DRY (or DRYLAND) CUCKOo, and Cardamine pratensis as WATER CUCKOO, fum their respcetive babitats. 
(4) Correspondents at Wiveliscombe and Withypool give it as a local name for the Red Campion, Lychnis dioica.

(5) A lady at Iwerne Minster (Dorset) tells me the name is given in that district to the Bugle, Ajuga reptans.

(6) In Devon the name is given to the Harebell, Campanula rotundifolia.

Cuckoo Boots. A correspondent at West Moors (Dorset) gives this as a local name for the Wild Hyacinth or Bluebell, Scilla non-seripta.

Cúckoo BRead. (1) Several Taunton correspondents give this as a local name for the Wood Sorrel, Oxalis Acetosella. Sse Cuckoo's BREAd AND CheEse.

(2) It is also an old country name for the Cuckoo Flower or Lady's Smock, Cardamine pratensis.

CUCKoo BUDs. A name applied in several parts of the district to various kinds of Buttercup (Ranunculus).

Cuckoo Buttors. The adhesive seed pods of the Boar-thistle, Cnicus lanceolatus, and of the Burdock, Arctium majus.

Cuckoo Flower. A name applied to a variety of plants which flower about the time of the arrival of the cuckoo, but most generally to

(1) The Lady's Smock or Bitter-cress, Cardamine pratensis.

(2) A fairly general name throughout the district for the Wood Anemone, Anemone nemorosa.

(3) The name is still frequently given to the Ragged Robin, Lychnis Flos-cuculi, which was once generally so called. The specific name Flos-cuculi is Latio for Ceckoo's Flower.

(4) In West Somerset and East Devon the name is frequently given to the Early Purple Orchis, Orchis mascula. Also to the

(5) Wild Hyacinth or Bluebell, Scilla nonscripta.

(6) Correspondents at Oakhill apply the name both to the Red and the White Campion, Lychnis dioica and L. alba.

(7) A correspondent at Watehet gives it as a loen num? for the Water Vio'et, Hottonia palustris.

(8) In Wilts the name is given to the Wood Strel, Oxal is Acetosella.

CUCKon MEAT. Woorl Sorrel, Oxalis Acetosella (Sexey's -School). W. Turner says "Oxys (i.e. Oxalis) is called in English Allelua, Cockowe's Meate, and Wod Sorel." A.D. 1543 "The Names of Herbs."

Cuckoo PIxt. (1) One of the most general ne mes for the Wild Arum, Arum maculatim. 
(2) A correspondent at Dunkerton gives this as a local name for the Red Campion, Lychnis dioica.

Cuckoo Roses. Daffodils, Narcissus PseudoNarcissus. Mr. Elworthy quotes one as saying, "The proper name o'm's Lent Lilies, but we always calls 'em Guckoo Roses."

Cuckoos. See Cuckoo.

Cuckoo's Boots. A name given in some parts of Somerset to the Wild Hyacinth or Bluebell. - See Cuchoo Boots.

Cuckoo's BREAD. Wood Sorrel, Oxalis Acetosella.

Cuckoo's Brfad and Cheese. (1) A name fairly general throughout the district for the Wood sorrel, Oxalis Acetosella.

(2) In N.W. Wilts the name is given to the young shoots of the Hawthorn, Cratogus monogyna. See BREAd AND CHEEse in each case.

Cuckoo's Buttons. See Cuckoo Buttons.

Cuckoo's Mteat. Wood Sorrel, Oxalis Acetosella ('Taun on and Burnham).

Cuckoo's Shoes ANd Stockings. (1) An old country name for the Cuckoo Flower or Lady's Smock, Cardamine pratensis, sent by several correspondents.

(2) A correspondent at Stogursey gives it as a local name for the Early Purple Orchis, Orchis mascula.

Cuchoo's Sorret. Same as Cuchoo's Meat.

Cuckoo SpIt. Same as Cuckoo's Shoes ANd STOCKINGS.

Cuckoo's Stockings. Bird's-foot Trefoil, Lotus corniculatus.

Cuckoo's Victuats. A Dorset form of CuCKoo's MEAT.

Cucumbers. The seed vessels of Iris Pseudacorus, which in their green state bear a close resemblarce to small cucumbers. (Rev. H. Friend.)

CUdde Me. An old country name for the Pansy, both wild (Viola arvensis) and cultivated (V. tricolor).

Cullenbeam. A common corruption in East Somerset and Wilts of the name "Columbine."

Culrage or Curage. Several correspondents. send this old name for the Water Pepper, Polygonum Hydropiper, of which Dr. Prior says: The old popular name comes to us through the French from the Latin culirabies, a plant so named, says Gerarde (p. 361) "from his operation and cffect when it is used in those parts." 


\section{Cuturerfoot. The Dove's-foot Cranesbill,} Gerani'm molle.

Culverkeys. Is an interesting old somerset name for some biue flower which many a uthorities have endeavcured to ident ify, but without stccess. Izaac Walton uses the name in his "Compleat Ingler.". Mr. J. Wr. White, F.L.S., in his "Flora of Bristol," says : "The word Culverkeys has long been a puzzle to writers on the subject of plant riames. It first appears in scme rather lidiculous lines upon Angling by John Dennys, of Pucklechurch in this district," and he favours the view that "Culverkey" was probably Ieadow Cranesbill (Geranium pratense). The author of "A Mendip Valley" considered it to he the Columbine (Aquilegia). The Century, The Encyclopædic, and The Cx'orl English Dictionary all indicate the Wild Hyacinth or Bluebell (Scilla nonscripta) as likely to be the true plant, and the last named work says the Braebel is sill knowir in s merset as "Culverkey." W. Miller in "English Names of Plants" gives this name to Scilla nutans, the Oxlip, Primula variubilis, and the fruit of Fraxinus excelsior, the Common Ash. In Kent the f rm Covey-keys is applied to the Oxlip, Primula elatior. It is also an old popular name (Rev. A. S. Palmer says) for Orchis morio, and is apparently a corruption of culverkins, i.e., little culvers or pigeons (A. Sax. culpe), to which its flowers were fancifully resembled.

CULVERTORT. Tho Columbine, Aqiilegia vulgaris, from the resemblace of its flowers to little heads of pigeons (culvers) feeding together. Compare Doves Round a Dish.

CuP AND SAUcer PLANT. A Taunton correspondent gives this as a popialar name for Cobca scandens variegata, a climbing plant of the Polemonium crder, a native of Mexiso, cultivated in this country.

Cupin's DART. A popular name for plants of the Catananche family.

CuP OF WINE. A correspondent at Hatch Beauchamp gives this as a local name for the Yer, T'axus baccata.

Cups. (1) This name is given by several correspondents at Paulton to single varieties of - the Canterbury Bell, Campanula, as distinguished from the double varieties, which they call Cups AND SAUCERS.

(2) A correspondent at Crewkerne gives this as a local name for the Hedge Convoliulus, Calystegia sepium.

Cups AND SAUCERs. A name given to several different plants, but most generally in this district to 
(1) The cultivated variety of Canterbury Bell, Campanula medium.

(2) Wall Pennywort or Navelwort, Cotyledon Umbilicus-Veneris.

(3) Several correspondents at Otterhmmpton give this as a local name for the single Daftodil, Narcissus Pseudo-Narciss:us.

(4) Mrs. Lansdowne, of Over Stowey, gives it as a local name for the double Polyanthus.

(5) S sveral sorrespondents at Evercrecch give it as a local name for th Marsh Marigold, Caltha palustris.

(6) A correspondent at Mells gives it is a local name for the Wood sorrel, Oxalis Acetosella.

(7) Acorns.

(8) Mexican Ivy Plant, Cobcea scandens.

Curdey Greens. Curly greens; curled Kinle, Brassica fimbriata.

Curbs Axd Creaxr.-London Pride, Saxifraga umbrosa.

Cunse. Cress (Rev. W. P. Williams).

Cunshins. Thrift, statice vulgaris (West Somerset).

Cushron Pink. Saa Pink or Thrift, stalice maritima, from the dense tufted growth of the leaves, and the resemblance of its flowers in their general appearance to pinks.

Cushions. (1) Same as Cushion PINk.

(2) Field Scabious, Scabiosa arvensis.

CUstin. A kind of small wild pium (Rev. IV. P. Williams).

Cut and Come Again. A very prolific variety of kale or winter greens, much grown in cottage gardens (F. T. Eiworthy).

CUT Finger. (1) A correspondent at B'oxworth (Dorset) gives this as a local name for the Periwinkle, Vinca major.

(2) Mr. 'T. W. Cowan tells me that in other' parts of the country this name is given to the Capon's-tail Griss, Valeriana pyrenaica.

Uut-heal. Di. Pirior gives this as a popular name for the Valerian, and things it may be from Dutch Kutte.

Cut Finger Leaf. The IVilts Glossary gives this as a N.W. Wilts name for All-heal, Valeriana, and says : "The leaves are good for application to sluggish sores, whitlows, \&e. Mr. Cunningt on quotes it as V. dioica."

DADDY-MAN'S BEARD. A correspondent at Dunster gives me this as a local name for the Wild Ciematis, or 'Traveller's Joy, Clematis Vitalba, more generally known throughout the district as OLD MAN'S BEARD, from the grey whisker-like tufts of seeds which follow the flower's and remain on the plant for months. 
DADDY'S BEARD OR DADDY'S WHISKERS. Variations of the above name received from other parts of the district.

DADDY WHITE-SHIRT. A correspondent at Chaffeombe gives me this as a local name for the Hedge Bindweed or Convolvulus, Calystegia sepium.

DAFFy AND DAFFy-Down-DiLly. Names very generally used by children for the Daffodil, Narcissus Pseudo-Narcissus.

DAFT BERries. The fruit of the Deadly Nightshade, Atropa Belladonna, which is highly poisonous.

DAGger Flower. The Iris, both the Yellow, Iris Pseudacorus, and the Blue, or Stinking, I. foetidissima.

DAGGERS. (1) The broad straight leaves of the common Iris or Flag.

(2) Correspondents at Over Stowey give this as a local name for the Wild Crocus (? Colchicum autumnale).

(3) Rev. Hilderic Friend says "In Somerset to a coarse w'de-leaved grass usually known as "sword-grass" or "withers -Poa aquatica" (Glyceria aquatica of the London catalogue).

DAIsIES. A correspondent at Furley gives this as a local name for the Ragwort, Senecio Jacobcen.

DALE CUP. (1) Buttercups of various species.

(2) Marsh Marigold, Caltha palustris. Compare DILL CuP.

DAMsEL. (1) Damson. Mr. Elworthy says : "Very, common; by some individuals always so called."

(2) Rev. Hilderic Friend spells it DAMzeL and says the name is "Vaguely applied to the fruit of Prumus spinosa and other large species both black and yellow."

Dancing Lady. The Fuchsia.

DANDELION. This name is frequently given erroneously to the Hawkbit, Coltsfoot, and other yellow flowers of the Dandelion family.

DANDY Gostings. (1) Early Purple Orchis, Orchis mascula (N.W. Wilts). Wilts).

(2) Green-Winged Orchis, O. morio (S.W.

DANDY GUSSET. This is sent me by a correspondent at Dowlish. Wake as a local name for the Marsh Orchis, Orchis latifolia.

Dane Ball. Dwarf Elder, Sambucus Ebulus

DANE'S BlooD. (1) The Dwarf Elder, Sambucus Ebulus. In Aubrey's Wilts, M.S., Royal Soc. p 120 we read :- DANE's BLOOD (Ebulus) about Slaught onford, is plenty. There was heretofore a great fight with the Danes, which made 
the inhabitants give it that name." Dr. Downes tells me that a similar legend is current at St. Erth, Colnwall, where. Dan wort flourishes in abundance. It is said that the wounded Danes were carried in litter's made of bundles of spears, and from these spears the Daneworts sprang. The probability of this derivation being the true one, however, is discounted by the fact that the plant is known as DANEWORT Or DANESWEED (which see) in other parts of England. The whole plant turus the most brilliant reds and crimsons in autumn.

(2) Mr. T. W. Cowan tells me that in some places this name is given to the Pasque-flower, Anemone Pulsatilla, and to

(3) The Clustered Bell-flower, Campanula glomerata.

Danesweed or Danewort. (1) Dwarf Elder, Sambucus Ebulus. Rev. H. N. Ellacombe, vicar of Bitton (1870), says:-It is not uncommon in our Bath flora, but is most abundant at Slaughterford, near Chippenham, a place where there was once a great victory gained over the Danes. The plant is called Danewort, and is an evil-smelling and noxious plant, and the legend tells us that it derived its evil qualities of all kinds from the Danes, on whose graves it grew so luxuriantly. See DANE'S BLOOD.

(2) Mr. T. W. Cowan tells me that in some counties the Field Eryngo, Eryngium campestre, is called DANES'-WEED. I believe this plant is very rare in Somerset, extinct in Devon, and not recorded as having been found in Dorset, Wilts, or Gios.

Daxgle (or Danginai) Bell. Soveral coriespondents at Paulton give me this as a locol name for the Lily of the Valley, Convallaria majalis.

DARLING OF APRII. A number of young people at Aller give me this as a local name for the Primrose, Primula vulgaris.

DASHEL. (1) A very common name in West Somerset and East Devon for the Thistle. There are several forms of pronunciztion, differing slightly and about equally common, but Mr. Elworthy says "in none is th ever sounded." I have the name also from other parts of the county.

(2) Mr. Harry Pouncy tells me that in Dorset this name is sometimes given to the Dandelion, Taraxacum officinale. It is also used in Devon. See DAZZLE-FLOWER.

Datches. Vetches (West Somerset). Over the greater part of my district Vetches are known as THATCHES, and in West Somerset the th becomes $d$; compare DASHEL (1).

David's Harp. Solomon's Seal, Polygonatum multiflorum. 
Davison. A species of wild plum, superior to the Bullace (Holloway).

DAY-BERry. Mr. T. W. Cowan says that in Cornwall this name is given to the IVild Gooseberry, Ribes Grossularia. It is a corruption of its popular name Thape or Theabe plus BerRy, the " $p$ " or " $b$ " being merged in the ensuing " $b$," so that the word became THA'-BERRX and then DAY-BERry. See DeBERrIES.

DAY LILY. A correspondent at Babcary gives me this as a local name for the Dandelion, Taraxacum officinale.

DAY'S EYE. I have this from all over the district as a popular name for the Daisy, Bellis perennis.

DAZzLE. Cnic:s arvensis and thistles generally (Devon). See DASHeL (1).

DAZZLE-FLOWER. A correspondent at Badford-on-Tone sends me this as a local name for the Dandelion, Taraxacum officinale. Compare DASHEL (2).

Deadly Nightshade. (1) The real Deadly Nightshade is Atropa Belladonna, but the name is very frequently given to the Woody Nightshade or Bittersweet, Solanum Dulcamara.

(2) Mr. F. W. Mathervs tells me that in East Dorset the name is given to the Common Nightshade, Solanum nigrum.

DEAD MAN. A correspondent at Durrington (Wiits) gives me this as a local name for the Broom-rape, Orobanche minor.

DEAD MAN'S BeLLS. A correspondent at Broadwindsor (Dorset) gives me this as a local name for the Foxglove, Digitalis purpurea.

Dead Man's Hand. Same as Dead Men's Fingers, but less commoniy used.

Dead Men's Bellows. Mrs. Day, of North Petherton, gives me this as a name for the Lousewort, Pedicularis sylvatica, often known as the Red Ratthe.

DEAD MEN's Fingers. $A$ faily general name throughout the district for the Early Purple Orchis, O. mascula, and the Spotted Orchis, O. maculata. Speaking of the latter Dr. Prior says the name is given on account of the pale colour and hand-like shape of the palmate tubers.

Dead Men's Thinbles. Foxglove, Digitalis purpurea.

DEAD NetTle: A name given to three plants which have nettle-like leaves, but which do not sting, and from their apparent insensibility , are generally called dead, deaf, blind, or " dunch" :-

(1) White-flowered, Lamium album.

(2) Red-flowered, L. purpureum. 
(3) Yellow-flowered, L. Galeobdolon.

(4) The name is also sometimes given to the Hedge Woundwort, Stachys sylvatica, frequently called Hedge-nettle.

DEAF AND Dumb. Several correspondents at Horton give me this as a local name for the Yellow Dead-nettle, Lamium Galeobdolon.

Deaf Nettle. See Dead NetTle.

DEATH's FLower. Several correspondents at. Brompton Regis give me this as a local name for the Snowdrop, Galanthus nivalis.

DEATH WARRANT. Miss Ella Ford, of Melplash (Dorset), gives me this as a local name for the White Bryony, Bryonia dioica.

DEBERRIEs. The fruit thus named in the "Devon Courtsbip" is the Gooseberry. It is said that Shakespeare probably referred to the Gooseberry whon he used the name Dawberries in his "Midsummer Night's Dream."

DeCFIVER. Ground Ivy, Nepeta hederacea. Sevecal young people send me tris name, wh ich I imagine is given to the flant on account of its blue flowers frequently being mistaken in the early spring for Violets.

DEER's HAIR. A Dunster correspondent gives me this as a local name for a Club-rush. Botanical friends tell me that the name is most frequently. applied to the Tufted Clib-rush, Scirpus coespitosus, which grows on the hills about Dunster, but is not common there. A larger plant, the Salt Marsh Club-rush, $S$. maritimus, is very common between Dunster and Minehead, and is probably also known in the neighbourhood as Deer's Hair. Both plants have tufts of slender stems, looking like coarse hair.

DELICATE BESS. The white variety of Valeriana celtica (Devon).

DeLr Cups. Buttercups of various species. Compare DALE-CuPs and DHL-CuPS.

Delticups. Creeping Ciowfoot, Ranunculus repens (Srrewton, Wilts).

Devil Ajong the TAILORS. Fennel-flower, Nigella damascena, more often called LovE-IN-AMIST or DEVIL IN A BUSH.

Devil DAIsy. (1) Common Ferelfew, Chrysanthemum Parthenium; and

(2) Stinkirg Chamomile, Anthemis Cotula, from their daisy-like flowers and umpleasant odour (S.W. Wilts).

Deviuduars. A correspondent at Puddletown (Do_set) gives me this as a losal name for the Ragwort, Senecio Jacobca.

DEVIr AND ANGELS. A correspondent at Stratton-on-tre-Fosse gives me this as a lccal name for the Ribwort Plantain, Plantago lanceolata. 
DEVIL IN A BUSH (or in a Den or a HeDGe). Fennel-flower, Nigella damascena, more commonly known as LOVE-IN-A-MIST.

DevIL IN CHURCH. A correspondent at Lytchott Matravers (Dorset) gives me this as a local name for Borage, Borago officinalis.

Devil May Care. Miss Ella Ford, of Melplash (Dorset), gives me this as a local name for the Dogwcod, Comus sanguinea.

DeVILS AND ANGELS. (1) Wild Arum or Cuckoo-pint, Arum maculatum.

(2) A correspondent at Tisbury (Wilts) gives it as a local name for the Wild Orchis (? Orchis miascula).

Devil's BANe. A correspondent at Martock gives me this as a local name for the Hairy St. Johr's Wort, Hypericum hirsutum.

Devil's Berries. The fruit of the Deadly Nigbtshade, Atropa Belladonna. Dr. R. C. Knight writes :- " It is interesting to note the number of times the word "Devil" is associated with poisonous plants. This must have served as a protection to childre-1 on numerous occasions."

DeviI's BIT. (1) The common plant Seabiosa Succisa, found growing in pastures. It bears a mauve-coloured flower on a long stem, and blooms in Aug ust and September. Gerard says " It is commonly called Morsus Diaboli or Divelsbit, of the root (as it seems) that is bitten off ; for the superstitious neople hold opinion, that the divell, for enuy that $1 \cdot e$ beareth to mankinde, bit it off, because it would le otherwise good for many vses."

(2) A. number of correspondents in the neighbourhood of 'Taunton give the name to the Small Knapweed, Centaurea nigra, doubtless through a confusion of the two plant:

DEVIL'S BLANKET. A Salisbury correspondent gives me this as a local name for the Great IIullein, Verbascum Thapsus.

DEVII's BLossom. A correspondent at Exmouth gives me this as a local name for the Hemlock, Conium maculatum.

DEVIL'S CANDLESTICK. (1) Correspondents in the Axminster district give me this as a local name for the Purple Medick or Lucerne, Medicago sativa.

(2) A correspondent at Rodden (Frome) gives it as a local name for the Ground Ivy, Nepeta hederacea.

DEVII's CHERRIES. (1) The poisonous fruits of the Deadly Nightshade, Atropa Belladonna.

(2) The berries of the Woody Nightshade or Bittersweet, Solanum Dulcamara-a common mistake through confusing this plant with No. 1. 
DEvu's CuAws. (1) Bird's-foot 'Trefoil, Lotu s corniculatus.

(2) Corn-field Crowfoot, Ramunculus arvensis.

DEVH'S Cups AxD SAUCERS. The Wood Spurge, Euphorbia amygdaloides, of which the flow $x$ suggests two little green cups standing in a green saucer.

Devil's Cut. Pulman says "The mood of the Wild Clematis, dried and used by naughty boss for smoking." See DEvil's GuTs (1).

Devil's DARNING NeEdLEs. A name given in some districts to the Skepherd's Needle, Scandir Pecten-Veneris.

Devu's Dexs. A correspondent at Camerton gives me this as a local name for the Fennel Flower. See DeviL IX a BusH.

DEVH'S Ere. (1) Correspondents at Tedmore and Kimmeridge (Dorset) give me this as a local name for the Greater Stitchrort, Stellaria Holostea.

(2) Another sorrespondent at Kimmeridge gives it as a lozal name for the Henbane, Hyoscyamus niger.

DeviL's Fiery PoKer. A correspondent at West Pennard gives me this as a local name for the Flame Flower or Red Hot Poker, Tritoma Uvaria.

Devil's Frwgers. Bird's-foot Trefoil, Lotus comiculatus.

DEVIL S FLowER. (1) A correspondent at South Petherton gives me this as a local name for the Hemlock, Conium maculatum.

(2) Mr. C. J. Tomkins, of Misterton, gives it as a local namie for the Greater Stitchwort, Stellaria Holostea.

DEVI'S GARTERs. A correspondent at Ilton gives me this as a local name for the small Bindweed, Convolvulus arvensis.

DEVH's GHLOFFER. A correspondent at Barrington gives me this as a local name for the red Wallflower, Cheiranthus Cheiri.

Devil's GuTs. (1) Wild Clematis or Tiaveller's Joy, Clematis Vitalba. Called in Germany "Devil's Band." See DEvil's CuT.

(2) The name is also given to the Dodder, Cuscuta. from the resemblance of its stems to catgut and the mischief it causes.

(3) Small Bindweed, Convolvulus arvensis, from its roots running down deeply into the ground and spreading rapidly abroad, defying the skill of the farmer or gardener to eradicate them.

DEviL's LEAF. Several correspondents at Aller and Martcck give this as a lceal name for the Great Nettle, Urtica dioica. 
Devil's MILKpaIL- $\boldsymbol{A}$ correspondent at Draycott tells me thav this name is commonly given in that district to the Dandelion, Taraxacum officinale.

Devil's Nightcap. Correspondents at Wimborne give me this as a local name for

(1) Hedge Bindweed or Convolvulus, Calystegia sepium.

(2) Greater Stitchwort, Stellaria Holostea.

DeviL's Paint Brush. A correspondent at Allerford gives me this as a local name for the Hawkweed, Hieracium, but does not name the species. Dr. Watson tells me that the Mo ase-ear Hawkweed, $H$. pilosella is the only Hieracium at all common in the district.

Devil's Pinches. A correspondent at Rampisham (Dorset) tells me tris name is sometimes, but not commonly, given in that district to the Spotted Persicaria, Polygonum Persicaria.

Devil S Pincushiox. A correspondent at Otterhampton gives me this as a local name for ihe Prickly Cactus, Echinopsis.

Devil's Piarthing. The common suinging Nettle, Urtica dioica; frequently called NAUGHTY MIAN'S PLAYIHING.

DeVII's PoKer. (1) Several correspondents at Bradford-on-Tone give me this as a local name for the Great Reed-mace, Typha latifolia, more zommonly called BuLrush.

(2) The Flame-flower, or Torch Lily. See DEVII'S FIERY POKER.

Devil's RHUbarb. (1) Several correspondents at Paulton give me this as a local name for the Deadly Nightshade, Atropa Belladonna.

(2) A correspondent at East Harptree gives it as a local name for "Wild Rhubarb," by which she probably means either the B urdock, Arctium, or the Butterbur, Petasites officinalis.

Devil's ShIRT Buttoxs. Greater Stitchwort, Stellaria Holostea.

Devil's SNuff-Box. A Puff-ball fungus, Lycoperdon, when fully ripe and giving off its spores when touched.

Devil's Spit. Several correspondents at Bradford-on-Tone give me this as a local name for the F̆napweed. See Devir's BIT (2).

Devil's Torch. Flame-flower or Red Ho Poker, 'Tritoma Uvaria (Otterhampton).

DeviL's Wand. Mfiss Ella Ford, of Melplash (Dorset), gives me this as a local name for the Fool's Parsley, Ethusa Cynapium.

Devil's Wort. A correspondent at Bradfordon-Tone gives me this as a local name for the Winter Aconite, Eranthis hyemalis. 
Devox Eaver or Evyer. Ry Grass, Lolium perenne. A name in use moie especially amongst somerset farmer.

Devon Pride. A correspondent gives me this name for. the Red Spur Valerian, Kentranthus ruber.

DEW-BERRY. A large kind of Blackberry, having fewer fruitlets and a more acid taste, and more juicy than the ordinary kind, growing on a low bramtle, Rubus cosius. Mr. Ti. W. Cowan tells me the name should properly be DoveBERRY, from the colour of its fruit; and it is known by the equivalent of this name in Germany and other countries. Mr. W. S. Price says "The berries always appear cloudy instead of bright as in the Blackberry, as if they were covered with mist $0^{n}$ dew-hence the name."

wDr. R. O. Knight writes:- "The genus Rubus has, of course, ever been a snare and a delusion, and I was pleasantly surprised recently to find in conversation on the roadside near Axminster that even local people realise this. Tre large juicy truits of one of the Rubi (I know not whi $\cdot h$, 1:ut I know it well by its leaves, large drupes and early ripening) were described to me as " . . . not hardly blackberries, more of a dewberry-growin' in covers." Tris, of "ourse, is very sound obser vation. The blackberries are not found in covers-rather on hedges, whil $t$ the dewberry end of the eries grows on low bushes in rough land, e.g., a recently coppiced cover.

DEW-CUP. A Shaftesbury correspondent gives me this as a local name for the Buttercup. Possibly a corruption of DILL-CUP.

Dew-Drops. A correspondent at Muchelney gives me this as a local name for the Snowdrop, Galanthus nivalis.

Dew of the Sea. Mrs. Lansdowne, of Over Stowey, gives me this as a local name for the Rosemary, Rosmarinus officinalis.

Dew-Plant. A number of young people at Paulton give me this as a local name for the Iceplant, by which I assume they mean Mesembryanthemum crystallinum, which is frequently called DEW-PLANT. It is a diffusely prozı mbent herbaceor s plant of the Fig-marigold fanily, popular on acsount of its cu iors large ovate wavy leaves, covered with large glittering pap:lae on every part, which glisten like ice in the $\mathrm{s}$ nshine, and acco: nt for its popular names.

DICKY BIrds. (1) Seeds of the Sycam or Acer Pseudo-platanus.

(2) Common Fumitory, Fumaria officinalis (S.W. Wilts).

DICKY BIRD's BILL. Cranesbill, Geranium (Paulton). 
Dicky Duder. A correspondent at West Coker gives me this as a local name for the Lesser Periwinkle, Vinca minor.

DILL-CUp (1) Bulbons Buttercup, Ranunculus bulbosus (Dorset and Wilts).

(2) Lesser Celandine, Ranunculus Ficaria (Dorset and Wilts).

(3) Marsh Marigold, Caltha palustris (Dorset).

Dilly Daffs. A colrespondent at Winsham gives me this as a local name for the Daffodil, Narcissus Pseudo-Narcissus.

Dilly DALLY. A correspondent at Everereech gives this as a local name for the Daffodil, N arcissus Pseudo-Narcissus.

Dimplewort. Correspondents at Shute (Devon) give me this as a local name for the Penny wort, Cotyledon Umbilicus-Veneris.

Ding Dongs. Harebell, Campanula rotundifolia (Melbury Osmond, Dorset).

Dingle Bell. Snowdrop, Galanthus nivalis (Paulton).

DIRT-ABED. Dandelion, Taraxacum officinale.

Dirt-Weed. White Goosefoot, Chenopodium album.

DiRTy Dick. A Wiltshire correspondent gives me this as a local name for the Goosefoot, as above.

Ditcander. Broad-leaved Pepperwort, Lepidium latifolium. Very rare in Somerset, and not found in Devon, Dorset,or Wilts. Lyte (1578) says "It is fondly and cinlearnedly called in English Dittany. It were better in following the Douchemen to call it Pepperwurt."

DOBBIN IN THE ARK. A correspondent at Muchelney gives me this as a local name for the Monk's-hood, Aconitum Napellus.

Dock Cress. A correspondent at Evershot (Dorset) gives $\mathrm{m}$ ? this as a local name for the Common Nipplewort, Lapsana communis.

Dockery Stick. Phosphorescent Wood (Re. V W. P. Williams).

Dock-FLower. (1) Several correspondents at Horton give me this as a local name for the White Goosefoot, Chenopodium album.

(2) A correspondent at Watchet gives it as a local name for the Amphibious Persicaria, Polygonum amphibium.

Dock-SEED. A correspondent at Axminster gives this as a local name for the Common Sorrel, Rumex Acetosa.

Doctor SHARP. A correspondent at Chideock (Dorset) gives this as a local name for the Crane'sbill, Geranium, but does not indicate the species 
[ [ gives me this as a local name for the Goosegrass or Cleavers, Galium Aparine.

Doctor's Medicine. (1) A Taunton correspondent gives me this as a local name for the Bramble, Rubus fruticosus.

(2) A correspondent at West Coker gives it as a local name for the leaves of the Dock, Rumex -obtusifolius.

Does My Mother WaNT ME? A correspondent at Shoscombe, near Bath, gives me this as a local name for the Rye-grass or Eaver, Lolium perenne, sometimes called T'INKER TAILOR GRASS, because girls seek to discover the occupations of their future husbands, and to answer many other questions by the number of spikelets.

Dogbane. The general English name of the genus Apocynum (from apo=away, and kyon=a dog; adopted by Dioscorides because the plant was supposed to be foisonous to $(\log \mathrm{s})$, but a correspondent at Compton (between Yeovil and Sherborne) gives it as a local name for the Henbane, Hyoscyamus niger.

Dog Berry or Dog Cherry. 'The fruit of the Dogwood, Cormus sanguinea.

Dog Cocks. Wild Arum or Cuckoo-pint, Arum maculatum (N.W. Wilts).

Dog DaIsY. (1) A fairly general name for the Ox-eye Daisy, Chrysanthemum Leucanthemum.

(2) A Watchet correspondent gives it as a local name for the Chamomile, by which he probably means Matricaria Chamomilla.

DOG DRAKE. A correspondent at Kimmeridge (Dorset) gives me this as a local name for the Privet, Ligustrum vulgare.

DOG FLOWER. A correspondent at Glastonbury gives me this as a local name for the Dog's Mercury, Mercurialis perennis.

Dog Poison. A correspondent at Axminster gives me this as a local name for the Fool's Parsley, Ethusa Cynapium.

Dog's CHERries. The brilliantly coloured fruits of the Red-berried (or White) Bryony, Bryonia dioica. See Dog BerRy.

DoG's Cols. Dog's Mercury, Mercurialis perennis.

DoG Rose. I correspondent at Babcary tells me that this name (which is almost everywhere given to the Wild Rose) is given in that district to the Gu sder Rose, Viburnum Opulus.

Dogs D' BArk. Snapdragon, Antirrhinum majus (Keinton Mandeville).

Dog's Dibble. Wild A'um or Cuckoo Pint, Arum maculatum (North Devon). 
Dog's Fexveq. A correspondent at Axminster: gives me this as a local name for th? Corn Chamomile, Anthemis arvensis.

DoG's Grass. (1) A name frequently given to the Couch-grass, Agropyron repens. Mr. 1". W. Mathews tells me this is the real dogs' cmetic; and $\mathrm{Mr}$. W. D. Miller writes: "It is the case that a dog will select with unerring instinct from a variety of grasses the leaves of Agropyron repons as modicine."

(2) Several correspondents at Chew Magna tell me the name is given in that district to the Soft Rush, Juncus effusus.

(3) Holloway and others give it as applied to the Crested Dog's-tail, Cynosurus cristatus, "because dogs eat the tops of it to ast as a vomit. Dr. Watson says "Some other grasses act similarly. 'The name is applied to any grass which dogs eat."

Dog's LICHex. Saveral correspondents in the Axminster district give me this as a lo:al name for the Ground Lichen, Peltigera canina.

Dog's Medicine. A correspondent at Sampford Brett gives me this as a local name for the Dog's Mercury, Mercurialis perennis.

DoG's Mouths. (1) A fairly general name for the Snapdragon, Antirrhinum majus.

(2) Yellow 'Toadflax, Linaria vulgaris.

DoG's Nose. Ssveral correspondents at Otterhampton give me this as a local name for the Snapdragon, Antirrhinum majus.

DoG's OATs. A correspondent at Widworthy (Devo.1) gives me this as a local name for the IVild Oats, Avena fatua.

Dog-SPEARs. The wild Arum or Cuckoo-pint, Arum maculatum. Mr. F. T. Elworthy quotes an under-gardener as saying "They'v a-got differ'nt names like, but we most times calls "em DoG-SPEARS."

Dog Stones. Several correspondents send me this as the name ot an. Orchis, but they do not indicate the species. Dr. Downes writes :$O$. mascula and $O$. morio, which have bi-lobed tubers, in contradistinction to $O$. maculata, whose tubers are hand-like. Compare DEAD MLAN's Fingers."

Dog's-TaIL Grass. The usual English name for Cynosurus cristatus. See DoG'S GRASS (3).

DoG's TAsser. The Wild Arum or Cuckoo-pint, Arum maculatum (West Somerset).

DoG's 'TeETh. A correspondent at Hatch Beauchamp gives me this as a local name for the flower of the Broad Bean. See Dog Teeth.

DoG's 'THIstue. Common Sэw-thistle, Sonchus olerace:s (Dunster). 
Dog's Trmber. (1) Dogwood or Wild Cornel, Cornus sanguinea. Mr. 'T. W. Cowan writes:"Degwood was undoubtedly originally dag-wood, the wood that skewers we.e made cf ; Old English dagge. Prior calls it Prick-uood " prick" being an old word for a butcher's skewer), Shewerwood, and Gad-rise (i.e., A. S. gad=a goad, and hris $=$ a rod) .

(2) A correspondent at Smallridge (Devon) gives it as a lecal name for the spindle-tree, Enonymus europcus. See DoG T'IMBER.

Dog's Tongue. Common Hound's Tongue , Cymoglossum officinale.

DoG TEETH. A correspondent at Stoke, St. Gregory giv as me this as a lccal name for the Coralwort, Dentaria bulbifera, which Mr. W. D. Miller tells me is not now found wild in Somes set, nor is it recorded from the West of England.

Dog TMmeR. (1) A Taunton correspondent gives me this as a local name for the Spindle-tree, Euonymus europceis. See DoG's 'TIMBER and DOG-WOOD.

(2) Rev. Hilderic Friend gives it as a Devon. shire name for the Mealy Guelder Rose or Wayfaring Tree, Viburnum Lantana.

Dog VIOLET. This is, of course, the common English name for the scentless blue Violet, Viola canina, but a correspondent at Stalbridge (Dcriet) gives me this as a local name for the Wild Pansy, Viola arvensis.

DoG-WOoD. Mr. T. W. Cowan tel's me that this name (which is the rsual English name for Comus sanguinea) is also given to

(1) The Spindle-tree, Euonymus europous.

(2) The Black Alder, Rhammus Frangula.

(3) The Guelder Rrse, Viburnum Opulus.

(4) Mr. W. S. Price tells me thrit in the Wellington district the Wayfaring 'Trec, Fiburmum Lantana, is always known by this name He has never heard it called Dog 'TIMBER.

Doleful Bells. Mrs. Montagu, of Cham mouth, gives me this as a lceal name for the Deadly Nightshade, Atropa Belladonna.

Dotr.'s Shoes. A Castle Cary correspondent gives me this as a lecal name for the Herb Robert, Geranium Robertianum. See DoLLY'S SHOEs.

Doluy Mounter. A fircone. Mr. Geo. Sweetman says "A Castle Cary word-not general," but I have heard the name many times in Yeovil, and have bad it sent me by several correspon dents.

DOLLY'S APRON. A common name in the Chard and East Devon district for the Herb Robert, Geranium Robertianum.

DoLty's BonNeTs. A correspondent at Sampford Brett gives me this as a local name for the 
Columbine, Aquilegia vulgaris, more often called Gransy's Bonnets.

Dolly's Nightcap. Correspondents in the Axn inster dist ict give me this as a local name fo: the Herb Robeit, Geranium Robertianum.

Dolly's PINAFORE. A variation of DOLLY S APRoN, from Axminster.

Doury's Shoes. (1) Correspondents at Muchelney and Creech give me this as a local name for the Columbine, Aquilegia vulgaris.

(2) Several correspondents in the Axminster district give it as a local name for the Herb Robert, Geranium Robertianum.

DoLty Soldiers. A correspondent at Cembe St. Nicholas gives me this as a local name for the Dove's foot Crane's-bill, Geranium molle.

DoNG BELL. A correspondent at West Coker gives me this as a local name for the Dafiodil, Narcissus Pseudo-Narcissus.

DonkeYs. A correspondent at East Harptree gives me this as a local name for

(1) Goosegrass or Cleavers, Galium Aparine.

(2) Burdock, Arctium.

DONkEY'S BREAKFAST. Thistle (Taunton).

DONKEY'S EAR. (1) The Woolly Woundwort, Stachys lanata; also called MousE's EAR, from the shape and hairy nature of the leaf. (Devon).

(2) Great Mullein, Verbascum Thapsus (Dorset).

DoNkEY's EARS. A number of young people at Winsham give me this as a local name for the Ribwort Plantain, Plantago lanceolata.

Donkey's OATs. The flowers and seeds of the Dock, Rumex obtusifolius, and the Sorrel, Rumex Acetosa (Devon).

DONKEY's TAILS. Several correspondents at Thorne St. Margaret give me this as a local name for OLD MIAN'S BEARD, by which I presume they mean Mare's-tails or Jointweed, Equisetum arvense.

Donkey's Tongue. A correspondent at Smallridge (Devon) gives me this as a local name for Love Lies Bleeding, Amaranthus caudatus.

DoNKEy's Thistle. Several young people at Oakhill give me this as a local name for the 'Teasel, Dipsacus sylvestris.

Dots AND DAsHes. A sorrespondent at Camerton gives me this as a local name for London Pride, Saxifraga umbrosa.

Dough-Fig. A Turkey fig, Ficus Carica, so called most probably from being soft as dough. The name is used to prevent onfusion arising between it and the ordinary raisin, which is called a "fig." 
Doves AT THE FountaIN. A Watchet correspondent gives me this as a local name for the Columbine, Aquilegia vulgaris.

Dove's Foot. The Dove's-foot Crane's-bill, Geranium molle, from the shape of the leaf.

Doves IN THE ARK. Columbine, Aquilegia vulgaris.

Doves Round A Dish. Columbine, Aquilegia vulgaris.

Down. A name given in Somerset to certain thistles which I cannot definitely identify. Several correspondents name the Common Cotton Thistle, Onopordum Acanthium, but this is a rare plant in Somerset, and Dr. Watson suggests there is probably some confusion between this and the Spear 'Thistle.

Downscwobs. A correspondent at Dorchester gives me this as a local name for the Marsh Marigold, Caltha palustris.

Dragon Frmes. (1) A Yeovil correspondent gives me this as a name for the Lobelia.

(2) From Evershot I have it as a local name for seeds of the Sycamore, Acer Pseudo-platanus.

Dragon Flower. A Devonshire name for the Yellow Iris, I. Pseudacorus, and the Blue (or Stinking) Iris, I. foetidissima. Possibly a corruption of "Dagger-flower," but several other possible derivations have been suggested.

Dragon's Buood. Correspondents at North Petherton and Fiddleford (Dorset) give me this as a local name for the IIerb Robert, Geranium Robertianum.

Dragon's Female. Mr. T. W. Cowan gives me this as an old name for Arum Dracunculus.

Dragon's Head. Mrs. Day, of North Petherton, gives me this as a local name for the Snapdragon, Antirhinum majus. Mr. T. W. Cowan reminds me that it is the general English name for the genus Dracocephalum.

Dragox's Mouth. Snapdragon, Antirrhinum majus (North Petherton, Martock, and Ilton).

Dragon (or Dragon's) Wort. (1) Anold nanie for the Snake-waed or Bistort, Polygonum Bistorta, sent by several correspondents.

(2) Holland \& Britten give Dragonwort as a popular name for Arum Dracunculus. Mr. T. W. Cowan tells me that Pliny calls it "Dragon," and says that its root " is somewhat red, and the same wrythed and folded round in manner of a Dragon, whereupon it took that name."

DROMEDARY. Knapweed, both Centaurea nigra and $C$. Scabiosa (Barford St. Martin, Wilts). 
Droopixg BeLL. Snowdrop, Galanthus nivalis (Paulton).

Drooping Bell of Sodox. His Honour $\mathrm{J}$. S. Udal gives this as a Dorset name for the Suakelily, Fritillaria Meleagris.

Drooping Heads. Snowdrop, Galanthus nivalis (Thorne St. Margaret and Sampford Arundel).

Drooping LILY. Snowdrop, as above (Castle Cary).

Droopixg Willow. (1) The Weeping Willow Salix babylonica (Devon).

(2) Also the "Golden Chain," Cytisus Laburnum, on account of its long elegant chains of gold hanging down like the branches of the Weeping Willow (Devon).

Drops of Brood. Mr. Edward Vivian, of Trowbridge, gives me this as a local name for the Scarlet Pimpernel, Anagallis arvensis, more generally called the Poor MAN's WeATHERGLASS.

Dropwort. A number of correspondents send me this as a local name for the Meadow-sweet, Spirac Ulmaria. The true Dropwort (Spircea Filipendula) and the Meadow-sweet are closely allied, but the latter grows mostly beside streams or in damp woods or meadows, and the former favours drier situations, where the soil is chalk or grivel.

DrUID's HAIR. Halliwell gives this as a Wiltshire name for long moss.

Druminer Boys. I correspondent at Chatmouth gives me this as a local name for the Small Knapweed, Centaurea nigra.

Druniner DAIsy. Ox-eye Daisy, Chrysanthemum Leucanthemum (Martock and Muchelney).

Drunarer Heads. Same as Drumarer Boys

Drumsticks. (1) Small Knapweed, Cen' taurea nigra (West Coker).

(2) A Tisbury correspondent gives m? this as a local name for the Burnet, Poterium officinale. (Mr. W. D. Miller suggests that the Salad Burnet. $P$. sanguisorba is probably intended).

Dronkards. This name is given to a number of plants; in this district perhaps most generally to

(1) The Marsh Marigold, Caltha palustris, on account of its fondness for water. The children say if you gather them you will get drunk; or if you look long at them you will take to drink.

(2) Red Spur Valerian, Kentranthus ruber, commonly known throughout a great part of the district as KISS-NIE-QUICK.

(3) Red Campion, Lychnis dioica, throughout a great part of Somerset, particularly in the West. 
(4) Ragged Robin, Lychnis Flos-cuculi (West Somerset).

(5) Herb Robert, Geranium Robertianum (North Petherton and Horton).

Drunkard's Nose. A Minehead correspon dent gives me this as a local name for the Red Spur Valerian, Kentranthus ruber. See DRUNKARDS (2).

Drunkex WILLY. A common name in West Somerset and East Devon for the Red Spur Valerian, Kentranthus ruber.

Drunken SAILOR. A Devon name for the Red Spur Valerian, Kentranthus ruber, more particularly used in the Plymouth district, but sent me by several correspondents in East Devon as being used locally.

Drunkits. Mr. F. W. Mathews tells me that in the Wellington district this name is given to the Red Spur Valerian. See Drunkards (2).

Dry (or Dryland) Cuckoo. White Meadow Saxifrage, Saxifraga granulata (S.W. Wilts). See Cucкоo.

Ducks AND Drakes. Eariy Purple Orchist Orchis mascula (Hammoon, Dorset).

Duck's BuLs. (1) The Yellow Iris, Iris Pseudacorus.

(2) Lilae, Syringa vulgaris; from the shape of the flowers (Devon).

(3) One of the many popular names given to Dicentra spectabilis ; frequently known as Bleeding Heart, Lady's Lockets, Chinaman's Breeches, The Lyre Fiower, dc.

Duck's Mостн. A Taunton correspondent gives me this as a local name for the Foxglove, Digitalis purpurea.

Dumb Canmor:K. Kest-harrow, Ononis repens (Wincanton).

Dusib Nettrf. (1) Most frequently the White Dead Nettle, Lamium album.

(2) In some districts applied also to the Red Dead Nettle, Lamium purpureum. See BurNd NetTle.

Dumiry Nettle Same as Duarb Nettle (1),

Duxch. White Dead Nettle, Lamium album (Wilts).

Dunch Netrte. (1) White Dead Nettle, Lamium album (East Somerset and Dorset).

(2) Red Dead Nettle, Lamium purpureum (S.W. Wilts).

Dun DaIsy. Ox-eye Daisy, Chrysanthemum leucanthemum. Probably a contraction of Dunder Daisy (which see) although it has been st:ggested that the name is possibly derived from "Dun," meaning a hill. 
DUXDER DAISy. Ox-eye Daisy, Chrysanthemum Le cunthemum. Doubtless a corruption of "Thunder Daisy." M[r. G. Clarke Nuttall says: "In Somersetshire there is an old tradition connecting it in some way with the 'Thunder Gorl."

DUNDLE DAISY. A variation of the last namo, sent me from Hateh Beauchamp.

Dusty Bов. The Cineraria (Otterhampton).

DUSTY MILLER. (1) A fairly general name for the Auricula, Primula Auricula.

(2) Mr. T. W. Cowan tells me the name is also given to Sa-side Ragiveed. Senccio Cineraria.

Duтch. White Clover, Trifolium repens.

DUTCH ËLDER. Goutweed, Egopodium Podagraiza (S. W. Wilts).

Dutchurax's Breeches. Mr. 'T. W. Cowan tells me that the true "Dutchman's Breeches " is Dicentra cucullaria, but the name is frequently applied to $D$. spectabilis, which is also known by a large number of other names, including CHINAIAN'S BREECHES and the LYRE FlowE., waich see.

Dutchalas's PIPE. A climbing shrub, a native of the Mississippi Valley, Aristolochia Sipho, introduced in 1763; sometimes called PIPE-VINE.

Dotch Mrrtie. Sweet Gale or Bog Myrtle Myrica Gale; from its abounding in Dutch bogs

Dwate. Deadly Nightshade, Atropa Belladonna. In the 14 th century this name was given to a drink composed of different herbs to stupify the patient when undergoing an operation. Once a general term for a sleeping draught, it has now been appropriated to this particular plant. Mr. T. 'W. Cowan tells me that a sleeping potion made of Hemlock and other materials is alluded to by Chaucer under this name :

Whenne Joseph had tolde this tale

Thei fel as thei had dronken duale

Grovelynge down on erthe plat.

DwInkLe. Pexiwinkle, Vinea (Brompton Regis).

DYeR's GREen WEed. Woad-waxen or Dyer's Whin, Genista tinctoria; so called from the fact that its young tops were formerly used by dyers to give a yellow colour to yarn.

DYeR's Rocket. A general English name for the Yellow-weed or Weld, Reseda Luteola, formerly much used by dyers. It is to the juices of this yellow weed that the artist owes the colour called Dutch pink.

DYER's WEED. Reseda Luteola. Same as DYER'S ROCKET. 
EA-Grass. See EAR-Grass and EE-Grass.

EAR-BOBS. The Fuchsia (Ilton). See EArDROPS.

EAR-DROPS. (1) A common name in Somerset and Devon for the Fuchsia.

(2) Dicentra spectabilis; see BleEdING HeidRT and Chinaman's BREeches.

EAR-GRASS. Young grass; the annual or biennial grasses sown upon arable land. Mr. Elworthy considered it should be "year-grass, i.e., annual. Rev. W. P. Williams defines it as "grass after mowing." See EE-GRASS.

Early Mushroom. Miss Ella Ford, of Melplash, Dorset, gives me this as a local name for the Butte-bur, Petasites ovatus.

EARLY Rose. Several young people at Oakhill give me this as a local name for the Primrose, Primula vulgaris. See FIRST ROSE.

EAR-RINGs. The Fuchsia (Axbridge). See EAR-DROPS.

Earth Gall. Common Centaury, Centaurium umbellatum, the leaves of which are intensely bitter, but possess valuable tonic properties. See Gall of the Earth.

EARTH NUT. The general English name for the Common Hog-nut, Conopodium majus.

EARTH SMOKE. An old English name given to several species of Fumitory, Fumaria, (particularly to $F$. officinalis), which in France bear the equivalent name of Fumeterre. The English and most of the continental names of the plant, as well as the scientific name, indicate its connection with smoke; some say because it covers the earth like smoke; others because it affects the eyes like smoke; but probably the true reason is that given by the Rev. C. A. Johns, who says the name was given because the smoke of this plant was said by the ancient exorsists to have the power of expelling evil spirits.

EARWIG. Mr. H. A. Bending, of Shoscombe. gives me this as a local name for the Lesser Convolvulus or Field Bindweed, Convolvulus arvensis.

EAster Beli. Rev. Hilderic Friend gives this as a Devonshire name for the Greater Stitchwort, Stellaria Holostea, from the time of its flowering, and the shape of the half-expanded blossoms.

EAster Flower. Several correspondents in Dorset and Devon give me this as a local name for the Wood Anemone, Anemone nemorosa. Compare PASQUE-FLOWER.

Easter Limy. The Daffodil, Narcissus PseudoNarcissus.

EAstern Star. Several correspondents at 
Arbridge give me this as a local name for tho Passion-flower, Passiflora ccrulea.

Easter Rose. (1) The Daffodil, Narcissus Pseudo-Narcissus.

(2) Mr. F. W. Mathews tells me that around West Buckland Corchorus japonica is always known by this name.

(3) A correspondent at Dunkerton gives it as a local name for the Primrose, Primula vulgaris.

Eaver. Common Rye-grass, Darnel, or Raygrass, Lolium perenne; usually called DEvoN EAVER by Somerset farmers; in Dorset called EVERY.

EE-GRASS. Aftermath or second crop; sometimes applied to Lammas grass also.

EGG-cuPs. The Tulip, Tulipa Gesneriana ; so called from the shape of the flowers, which are sometimes known as WINE-GLASSES for the same reason.

EgG IN the PAN. Mrr. W. C. Baker, late of Maunsel, gives me this as a local name for the Yellow Alyssum.

Egr Plant. A herb of the Nightshade family, Solanum Melongena (or esculentum), extensively cultivated and often seen in cottage windows. It bears large egg-shaped edible fruit, white, Jellow, or dark purple.

EgGs ANd Bacon. A name given to a number of different flowers, particularly those which contain two shades of yellow or yellow and rosecolour. Most frequently given in this district to

(1) Narcissus of all kinds, including the Jonquil and Daffodil.

(2) Yellow Toadflax, Linaria vulgaris.

(3) Bird's-foot Trefoil, Lotus corniculatus.

(4) Water Crowfoot, Ranunculus heterophyll:s.

(5) The stalks of the Dewberry, Rubus ccesius.

(6) A well-informed correspondent at Watchet gives me this as a local name for the Grass of Parnassus, but as our only native species (Parnassia palustris) is exceedingly rare in this part of the country, I presume the name refers to some cultivated variety. Mr. W. D. Miller adds "Pamassia has not been seen in Somerset for 100 years, and I know of no cultivated variety."

(7) Several correspondents at Paulton give it as a local name for the flower of the garden Potato, Solanum tuberosum. See BACON AND EGGs.

EgGs ANd Butter. (1) Narcissus of almost every kind, including Daffodils and Jonquils.

(2) Yellow Toadflax, Linaria vulgaris.

(3) Meadow Buttercup, Ranunculus acris. Probably most of these flowers are more trequently called ButTer AND EGGS, which see. 
EgGs Axp Collops. Yellow Toadflax, Linaria vulgaris (Rodden, near Froms).

Egas Egas. Fruit of the Hawthorn, Cratcegus monsgyna (S.W. Wilts). Piobably connected with A.S. haga, Dutch heg $=$ a hedge. Mr. G. T. Onions writes me " EGG mu t be an unaspirated form of heg, a by-form of hag (you have the (iminutive in aglet). Hag is again a parallel form of Haw, Wnich is the widespiear name for the beiry of the Hawthoin." It has also been suggested that the name is perhaps derived from a perversion of HEDGE-PEGS, although this latter name is usually applied to the Sloe.

EgLANTINe. An old English name for the Sweetb:iar, Rosa Eglanteria; frequently used by the older poats or the WI d Ro e.

EgLet. The Haw ; fruit of the Whitethorn, Cratcogus monogyna (Dəvon). Səe AGLET.

EGLET-BLoox. Hawihorn blossom (see above).

Elder Trot or Eldrot. Gow parsnip, Heracleum Sphondylium.

Eldroot. Rev. Wm. Banes (Dorset) define this as "the stalk and umbel of the Wild Parsley." See Eltrot (2).

ElepHaNT's EAR. (1) A common name for the genus Begonia.

(2) Mliss Ida Roper informs me that the name is also given to a shrubber'y species of Ivy.

ELEM OR ElLUMI. A very common pronunciation in Somerset, Dorset, and Devon of the name Elm, Ulmus campestris, from which we have the adjective ELENEN-made of elm. Dr. R. C. Knight quotes a native of East Somerset as saying "The Elus idden a tree, he's a weed, because if you d' stick a elum pwoost in groun' he d' sprout an' grow."

Eleven O'Clock Lady. Star of Bethlehem, Ornithogalum umbellatum. The French call it by the equivalent name of Dame d'onze heures, from its waking up and opening its eyes so late in the day.

ELF-CUP. Any cup-shaped fungus of the former genus Peziza (now split up); probably the best known being Geopyxis coccinea, the Searlet Elf-cup, commonly called in Somerset Soldiers' Caps or Jerusalen Stars. See FaIry GUPS (3).

Eltrot. (1) The usual name in East Somerset, Dorset, and West Wilts for the Cow-parsnip Heracleum Sphondylium, generally kown in West Somerset as LIMPERSCRIMP.

(2) Rev. Hilderic Friend says : "A stalk of Wild Parsley is in the Western Counties called ELTROT." 
(3) Dr. R. C. Knight informs me that in at least one village in North Dorset the name ELTRoT is applied to garden Rhubarb, Rheum Rhaponticum. It is a local saying that "Ansty Randy (= fair) d' come the second month (!) of Maäy an' you d' always have ELTRot-pi :.'

Emants' StaLK. Several correspondents at South Petherton give me this as a local name for the Purple Loosestrife, Lythrum Salicaria.

EMONy oR ENEMry. Corruptions of the name "Anemone," very frequently heard in the district. Mr. Elworthy says the former is 20 common gardener's name. "The common people call them Erones." Coles, "Adam in Eden," 1657.

English Fly-trap. Round-leaved Sunder, Drosera rotundifolia.

Evening Close. Miss Ella Ford, of Melplash (Doiset), gives me this as a local name for the White Campion, Lychnis alba.

EVEnING PrIDE. (1) Several correspondents in the Axminster district give me this as a local name for the Honeysuckle or Woodbine, Lonicera Periclymenum.

(2) One correspondent in the same district gives it as a local name for the Evening Primrose.

Evening Primrose. This is the genera, English name for Enothera biennis, from its pale yellow colour and its opening at sunset. The name is som times given - I believe in mistake-to the Great Mullein, Verbascum Thapsus'

Evening TwILIGHT. Miss Ella Ford, of Melplash (Dorset), gives me this ais a local name for

(1) The Wood Sorrel, Oxalis Acetosella.

(2) The Wood Anemone, Anemone nemorosa,

Ever-GRass. Common Rye-grass, Ray-grass, or Dainel, Lolium perenne. Mr. 'l. $\%$. Cowan writes:-EVER, EVER-GRAss, and EVERY are corruptions of the French ivraie, so called from its power to inebriate or make drunk (ivre). The first part of the name RAY-GRAss also represents the French ivraie=drunkenness, from the supposed intoxicating quality of some species (Pior). In the North of England it is named Drunk. See EAVER.

Everuasting. Any flower which retains its colour and shape when dried, as the species of Gnaphalium, Helichrysum, Rhodanthe, Antennarias \&c.

Everlasting Pea. Perennial Sweet Pea. both Broad-leaved, Lathyrus latifolius; and Narrow-leaved, L. sy!lest is.

EVERY. A Dorset form of EVER-GRASs, which see. 
EvE's APRON. A correspondent at Bruton gives me this as a local name for the large-leaved Saxifrage, but Dr. Watson writes me "There is no Saxifrage except Saxifraga tridactylites native at Bruton. Unless Saxifrage itself is a mistake it must refer to a cultivated plant. London Pride $(S$. umbrosa) is the only one I have seen cultivated there." It may possibly refer to the Golden Saxifrage, which is a Chrysosplenium.

Eve's Cushion. Mr. Edward Vivian gives me this as a name for the Mossy Saxifrage, Saxifraga hypnoides.

Eve's Tear. A correspondent at Stoke-underHam gives me this as a local name for the Snowdrop, Galanthus nivalis.

Ewe Brinble. The Common Bramble, Rubus fruticosus. MT. F. T. Elworthy says: "The term is generally applied to an individual specimen and mostly when of a coarse rank growth. Brooms made of heath are always bound round with a Ewe Brimble." See HeW-Mack

ExEBRIGHT. This is another name which is applied to a number of different plants.

(1) It is the general English name of Euphrasia officinalis, formerly in great repute for diseases of the eye, in consequence of an old legend which says that the linnet uses this plant to clear its sight.

(2) Mr. Elworthy says that in West Somerset the name is most commonly applied to the Germander Speedwell, Veronica Chamodrys, generally known in Somerset as BIRD's-EYES.

(3) It is also applied in West Somerset to the Common Alkanet, Anchusa officinalis, and to the

(4) Greater Stitchwort, Stellaria Holostea.

(5) Several young people at Mark tell me the name is given in that district to the Poppy, Papaver Rihoeas.

(6) Several young people at Brompton Regis give it as a local name for the Wild Pansy, Viola arvensis.

(7) Rev. Hilderic Friend gives it as both a Somersetshire and a Devonshire name for the Rose-bay Willow-herb, Epilobium angustifolium, called CATS'-EYES in some parts of England.

EYE GlaAsses. A correspondent at Chard gives me this as a local name for the Scotch Pine, Pinus sylvestris, but it is not easy to see the connection.

F Exe of Day. A number of young peopla in different parts of the county send me this as a local name for the Daisy, Bellis perennis. lus.

FACE IN Hood. Monkshood, Aconitum Napel-

FAIRIES. Mr. F. R. Summerhayes, of Milborne Port, tells me that this rame is given in that 
district to the staminate, carpellate, and neute florets of the Wild Arum, Arum maculatum.

FAIRIES' BAsIns. (1) A correspondent at Evercreech gives me this as a local name for the Cowsiip, Primula veris.

(2) Several correspondents in the Axminster distrizt give it as a local name for Buttercups, Ranunculus.

Fatrmes' Bath. Miss Ella Ford, of Melplash (Dorset), gives me this as a local name for the Water Avens, Geum rivale.

FAIRIES' BEDs. 'The same correspondent gives me this as a local name for the Figwort, Scrophularia.

FAIrIES' Bells. (1) The Foxglove, Digitalis pierpurea.

(2) A correspondent at South Petherton gives it as a local name fur the Lily of the Valley, Convallaria majalis.

(3) A correspondent at Mells gives it as a local name for the Wild Hyacinth or Bluebell, Scilla non-scripta. See FATRY BELLS.

FAIrifes' Broom. The 'Teasel, Dipsacus sylvestris (Thorne St. Margaret and North Cheriton).

FAIrIEs' OAPS. The Harebell, Campanula rotundifolia (Trowbridge).

F'ATRIES' CIOCK. A correspondent at Musbury (Devon) gives me this as a local name for the Moschatel, Adoxa Moschatellina.

FATRMa' Cups. Several young people at Paulton give me this as a local name for the Arum Lily.

FAIRIES' FIRE. A correspondent at Paulton gives me this as a local name for the Teasel, Dipsacus sylvestris.

FAIRTES' Flower. 'The Cowslip, Primula veris (Stogursey).

FAIRIES' GLoves. The Foxglove, Digitalis purpurea Also salled FATRY GLoves.

FAIrIES' Kers. A correspondent at Dalwood (Devon) gives me this as a local name for the Oxlip, by which is no doubt intended the hybrid between the Cowslip and the Primrose.

FATRIES' LANTERNS. A correspondent at Dunkerton gives this as a local name for the Yellow Toad-flax, Linaria vulgaris.

FaIrIes' PaInT-Brushes. The Periwinkle, Vinca (South Petherton and Ilminster distrist).

Falries' Petriconts. Foxglove, Digitalis purpurea (Odcombe and Taunton).

FAIRIEs' ThInrbles. (1) The Harebell, Campanula rotundifolia (Dunster and Brompton Regis). Dr. Watson, however, tells me the Harebell is extremely rare in these districts.

(2) The Foxglove, Digitalis purpurea. 
FAIRIfS' Unibreli. A correspondent at Combe St. Nicholas gives this as a local name for the Field Bindweed, Convolvulus arvensis. See also FAIRY UMBRELLA.

Fatries' Wand, (1) Miss Ella Ford, of Nelplasb (Dorset), gives this as a local name for the Agrimony, Agrimonia Eupatoria.

(2) A correspondent at Netllecombe gives it as a local name for the Great Niullein, Verbascum Thapsus.

FATRIES' WINDEL.OWER. A zorrespondent at Chideock (Dorset) gives this as a local name for the Wood Anemone, Anemone nemorosa.

FATRIES' WINE-CUPS.-The small Bindweed. Convolvulus arvensis (North Cheriton).

FAIR MaIds OF February. (1) A very general name for the Snowdrop, Galanthus nivalis.

(2) Several correspondents at Dunster give it as a local name for the Nareissus.

FAIR MaIDS of France. (1) Mrs. Linisdowne, of Over Stowey, gives me this as a local name for the Marguerite Daisy or Ox-eye, Chrysanthemum Leicanthemum.

Mr. 1. W. Cowan tells me that the name is also given to

(2) Ranunculus aconitifolius.

(3) The White Mountain Saxifuage, Saxifraga granulata.

(4) The Sneeze-wort Yarrow, Achillea Ptarmica.

E'ATRY BELLS. (1) A number of correspondents at South Petberton and in other districts give this as a losal name for the Foxglove, Digitalis purpurea.

(2) I'he Harebell, Campanula rotundifolia.

(3) The Cowslip, Primula veris (Bradiord-onTorie).

(4) Wild Hyacinth or Bluebell, Scilla nonscripta (Evercrecch and Camerton).

(5) A correspondent at Cerne Abbas gires it as a local name for the Daffodil, Narcissus PseudoNarcissus.

(6) A correspondent at Stockland (Devon) gives it as a lical name for tre Wood Sorrel, Oxalis A cetosella. See FATRIES' BELLs.

FAIRY BoAts. A Taunton correspondent gives me bis as a local name fo: the Water Lily, Nymphoea lutea.

FAIRY BUD. A school-boy at West Coker give: me thi; as a li eul neme for the "Deadly Nightshade," by which he probably means the Woody Nightshade, Solanum D. lcamara.

FAIRY CAP. (1) 'Th F Foxglove, Digitalis purpurea (Tauntor, Uver Stowey, Duwlish Wake, ard oth $\cdots$ district:i).

(2) The Harebell, Campanula rotundifolia (Trowbridge). 
FAIRY Chense. Common Mallow, Malva sylvestris (Stalbridge). See CHEEsEs.

FAIry Chensecake. Mr. Edward Vivian (Trowbridge) gives me this as a local name for a Medick-I presume Medicago lupulina.

FArry Clocks. Seed-beads of Dandelion, Taraxacum officinale (Milhorine Port and Mark).

FAIRy Cups. (1) Tle Cowslip, Primula veris (Bradford-on-Tone, North Petberton, West Coker, and other districts).

(2) A correspondent at Chetnole (Dorset) gives it as a local name for the Harebell, Campanula rotundifolia.

(3) Any cup-shaped fungus of the genus Peziza, particularly $P$. coccinea. See ELF-cup.

FAIRY DELL. Miss Ella Ford, of Melplash (Dorset), gives me this as a local name for

(1) The Sun Spurge, Enphorbia Helioscopia.

(2) The P tty Spuige, E. Peplus.

FAtRy Fingens. The Foxglove, Digitalis purpuree (Ilmirster and Combe St. Nicholas).

FATry Flux. (1) Catrartic Flax or Mill Mountain, Linum catharticum. The Rev. H. N. Ellacembe, lecturing at Bath over 40 years ago,

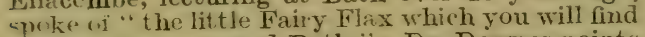
on your downs yound Bath." Dr. Downes points out that the flowers of this plant are white, so that our "Faisy Flax" cannot be that of Longfellow, who wote in his "Wreck of the Hesper us,"

Blue were her eyes as the Fairy Flax.

(2) Several young people at Wembdon apply the name to a plant of the genus Ipomara.

(3) A correspordent at Wincarton gives it as a local name ior the Scabious, ? Scabiosa arvensis.

FAtry Groves. The Foxglove, Digitalis purpurea. Also called FAIRIES' GLoves.

FAIRY HAT. A correspondent at Charmouth (Dorset) gives me this as a local name for the Foxglove, Digitalis purpurea.

FATRY Pops. (Pops=sweets). The School Mistress at Beaminister gives me this as a local name for the Red Clover, Trifolium pratense, known thoughout a great part of the district as HoNeysuckle. Butb names refer to the sweetness which children extract by sucking tbe flower's.

FATRY QueENs. A correspondent at Hatch Beauch mol giv 12 this as a local nam. for the Pansy, Viola.

FATRY RINGers. The Harebell, Campanula rotundifolia (Hammocn, Dorset).

FAIRY RINGs. Circles or parts of circles in pastures of a darker green and more luxuriant growth than the adjoining parts. most observ- 
able whe the grass is short. They were formerly believed to mark the dancing places of fairies, and Mr. E. W. Swanton says they are to this day a puzzle to many of the old shepherds in Wilts and Dorset (why not in Somerset?), who vouchsafe the explatiation "Zome do say they do some by lightnen wher do thunder." The Rev. M. J. Berkeley, in his "Outlines of British Fungology," says :- "It is believed that they originate from a single fungus, whose growth renders the soil immediately beneath unfit for its production. The spawn, however, spreads all around, and in the second year produces a rop, whose spawn spreads again, tre soil behind torbidding its retarn in that direstion. Thus the circle is co tivually increased and extends indefinitely till some cause intervenes to destroy it. The manure arising from the dead fungi of the former years makes the grass pe aliarly vigorous round, so as to render the sircle visible even when there is no external appearance of ike turgus, and the contrast is often the stronger from that berivd being killed by the old spawn." Mr. E. IV. Swanton, in his "Fungi and How to Know Them" (1909), says: "Later writers hold that a single fungus does not usually give rise to the circle in pastures, but that anything which may kill a small patch of grass-e.g., a heap of rotten manure-and thus provide a suitable matrix, may be a cause." The best known of these circle-forming fungi are the Fairy Ring Champignon, Marasmius orcades and $M$. urens, but Dr. Watson tells me that the St. George's Mushroom. Tricholoma gambosum, seems to be more noticeable in Somerset.

FAIRy Stoous. 'Toadsools (Long Sutton).

FAIRY Tables. A zorrespondent at Muchelney gires me this as a local nare tor Mushrooms

Famry T'minbles. The Foxglove, Digitalis purpurea. Called also FAmI is' THIMBLEs.

FAtry Trumpets. (1) A number of corres pondents at South Petherton give me this as a local name for the Honeysuckle or Woodbine, Lonicera periclymenum.

(2) A correspondent at Evershot gives it as a local name for the Hedge Convolvulus, Calystegice sepium.

FAIRY UMbrella. A correspondent at Sherborne gives this as a local name for the Field Bindweed. See FAIrIes' Umbrella.

FAuse Buosson. The male flower of Melon or Cucumber (always). Said also of any blossom which fails to set. (F. T. Elworthy).

FAREWELL SUMMAR. (1) A fairly general name for several species of Aster, popularly known as the Michaelmas Daisy. 
(2) Several correspondents in Dorset give it as a local name for Phlox.

Both plants are also known as SUMMER FAREwELL, which see.

Farmers' Clocks. A Taunton correspondent gives me this as a local name for tbe Dandelion, Taraxacum officinale.

Farmer's Weather-Glass. Mrr. W. S. Price gives me this as a local name for the Scarlet Pimparnel, Anagallis arvensis in the Wellington and Milverton district. More generally known as Poor Man's or Shepherd's Weather-glass.

Fat Beilnes. Bladder Campion, Silene talifolia (Nettlecombe).

Fat Hen. (1) A fairly general name for the White Goosefoot, Chenopodium album.

(2) A Taunton correspondent gives it as a local name for Polygonum Persicaria. Dr. Watson tells me this is due to confusion between the two plants which often grow together.

FAther Big-FACE. A correspondent at Evercreech gives me this as a local name for the Nodding (or Musk) Thistle, Cardius nutans.

FATHer TIME. Wild Clematis or Trareller's Joy, Clematis Vitalba, in seed; generally called in East Somerset and Dorset OLD MAN's BEARD.

FATHERY HAN. In Chap. 16 of "Clara Vaughan," Mr. R. D. Blackmore applies this name to the Valerian.

FEATIER FERN. Spircea Japonica, on account of its gracef 1 feathery bunches of flowers (Rev. H. Frievd).

Feather Few, Foe, or Fold. Common Feverf $\in$, Chrysanthemum Parthenium. This name-written ard prono ned in an almost endles variet $r$ of ways - is really a com uption of Febrifuge (Lat. febris fuga $=$ what puts fever to flight); or possibly, as Dr. Prior suggests, from confusion with the name FEATHER-FoIL, which see. Dr. Watson writes me :- "No doubt confusion has occurred. No doubt Febrifuge (= fever fly-away) is the origin of Feverfew, but probably the name of Featherfoil (= feathery leaves) has really been applied to the plant, and is so still in the north in places where the Water Violet is unknown."

FeATHER-FoIL. (1) The Water Violet, Hottonia palustris. The popular name means feathery leaf, in reference to the finely divided leaves of the plant.

(2) Miss M. J. Shute tells me that in Devon this name is given to a Common Chamomile, very aromatic.

Feathers. (1) argenteum.

Pampas

Grass, Gynerium 
(2) A correspondent at Stalbridge gires this as a local name for the Amaranth, known as Love Lies Bleeding, Amaranthus caidatus.

FeAther Putane. Pampas Grass, Gynerium argenteum (ivinstame).

FeAtHery SImAmock. Several young people at. Aller gire me this as a local name for the Clover, T'rifolium.

FEBRUARY FATR-MIAD (or MAIDEN). The Snowdrep, Gialanthus nivalis.

FELON-WORT. The Woody Nightshade or Bittersweet, Solanum dulcamara. From its use in curing whitlows, called in Latin furunculi, little thieves, that is, felons.

FFNNEL-FLOWER. The general English name for Nigella damascena, popularly called Lov. in a Mist, or Devil in the Bush.

FER BUTT-R-CUP. Silverweed, Potentilla Anserina (S.T. IVilts).

FERN-LEAVED DAIsY. A correspordent at Paulton gives me this as a local name for the Scentless Mayweed, Matricaria inodora.

FEVERTORY. A Wiltshire name for the Fumitory, Fumaria, from which a cosmetic for removing treckles used to be distilled. A Wiltshire rhyme says :-

If you wish to be pure and holy,

Wash your face with fevertory.

Findles. (1) Water Figwort, Scrophularia aquatica, so called because if two of the stalks are draw $r$ across eacb other as a bow is drawn across the strings they make a noise like a fiddle. See CROWDX KrT.

(2) Dr. Watson tells me this name is also given to the Knotted Figwort, $S$. nodosa.

FiddLestick. An alternative Devonshire name for the Figwort, as above.

FindLe STRINGs. (1) The Water Figwort. See Fiddies.

(2) The ribs of the Plantain leaf when pulled out (Castle Ca:y and N.W. Wilts).

FIELD DAISY. A correspondent at Watchet gives this as a local name for the Feverfew, Chrysanthemam Parthenium.

Freud Lumes, A correspondent at Soutb Petherton gives this as a lccal name for the Yellow Iris, Iris Pseudacorus. Probably some confusion. Dr. Watson writes:- "FIELD is scarcely right as qualifying Litues in regard to the Flag. It would be more suitable for the Foetid Iris, which actually grows in fields and not only in wet places. I suppose LrIIES is used because of the leaf being like a Lily, and not in reference to the flower." 
Fighting Cocks. Various Plantains, pasticularly the Ribwort or Cock-grass, Plantago lanceolatc, and the Foary or Lamb's Tongue, P. media. Children fight them head against head. See COCK's HEADS and SOLDiERS.

Fias. The common name in Somerset and Devon for raisins. Some years ago a correspondent asked in t\} e Western Antiquary why people in this part of England called raisins figs, and a plum pudding figgy pudding; and the was met with the counter question, "Why do you speak of plum pudding when you mean raisin. pudding?"

Finger Cap. Mirs, Day, of North Petherton, gives me this as a lcual name for the Foxglove, Digitalis purpurea.

Finger Hut. 'Two correspondents at Stockland (Devon) give this as a local name for the Foxglove; see above. Dr. R. C. Knight writes : - "This is worthy of $\mathbf{r}$ mark. Presumably HUT is the same word as the Somerset hud, i.e. a finger-stall, derived from hood."

FInGers. The Foxglove, Digitaiis purpurea (West Somerset and Stowey, near Clutton).

Fingers AND Thunbs. This name is applied to a number of different lowers, but most generally in this district to the

(1) Bird's-foot 'Tr:foil, Lotus comiculatus.

Correspondents in valious paits of the district give me tre name as being applied to the following flowers, but whether they are botanically correct in naming the species in every case I am unable to say.

(2) Tufted Veteh, Vicia Cracea (Sempford Brett, Melplash, Iwerne Minster).

(3) Meadow Vetehling, Lathyrus pratensis (Weston Zoyland, Brompton Regis, Donhead).

(4) Yellow Vetehling, Lathyrus Aphaca (Luxborough, Bradford-on-Tone). Dr. Watson writes

"Very questionable, as L. Aphaca is not known to me from either of these localities."

(5) Kidney Vetch, Anthyllis Vulneraria (Stockland, Cbarmouth, Widwortby).

(6) Horse shoe Vetch, Hippocrepis comosa (Queen Camel).

(7) Purple Vetch, Vicia sepium (Sexey's Sehool).

(8) Red Campion, Lychnis dioica (Sexey's School).

(9) Yellow Toadflax, Linaria vulgaris (Nettlecombe, Sampford Arundel).

(10) Foxglovn, Digitalis purpurea (Oakhill).

(11) Yellow Corydalis, Corydalis lutea (Stoke Abbott).

(12) In East Somerset and Wilts the name is frequently given to the flowers of the Furze, Ulex europxus. 
(13) Rer. Hilderic Friend gives it as a Devonshire name for the Lady's Slipper, Cypripedium Calceolus. Mr. W. D. Miller writes: "Not one person in 10,000 in Devon ean ever have seen the Cypripedium. Undoubtadly Lotus corniculatus is meant."

Fingers AND Toes. Two correspondients a Axminster give me this as a local name for tre Bir d's-foot Trefoil, Lotus corniculatus.

FINGER TIPS. A correspondent at Donhead (Wilts) gives me this as a local name for the Foxglore, Digitalis purpurea.

Fin Bob. A fir-cone (West Somesset).

Fir Cog. A fir-cone (Bridgwater).

Fire Flout. An old country name ror the Poppy, Papaver Rhoeas.

Fire Grass. A Yarlington school joy gives. me this as alocal name for the Plantaio. See Fire Leaf.

Fire Leaf. A correspondent at Muchelnes gives me this as a local name for the Ribwort Plantain, Plantago lanceolata. See FIRE GRASs. Miss Ida Roper adds " See " Garde zer's Ghronicle, 1860 , p. 738, quoted Flora of Bristol, p. 501."

FIRE LruY. A correspondent at Buckerell (Devon) gives me this as a local name for the Tiger Lily, Lilium tigrinum.

FIRE SCREEN. A zorrespondent at Broadstone (Dorset) gives me this as a local name for the Flame Nasturtium, Tropocolum speciosum.

Frr Gog. A fir-cone (Wellington district). Mr. F. IV. Mathews quotes a woman saying "I always picks up a lot o' they vur-gogs; they be better'n fire-lighters."

Firley Gog. A fir-cone (Sampford Arundel).

First Flower of Spring. A correspondent at Evercreech gives me this as a local name for the Crocus.

Firs' Rose. From all parts of the district I rave had this sent me as a popular name for the Primose, Primula vulgaris. See EARLY Rose.

Fish Bones. (1) A correspondent at Ilton gives me tris as a lo zal name for the Silver Weed, Potentilla Anserina.

(2) Several correspondents at Bridgwater tell me that this name is there given to the leaves of tl e Horse Chestnut, Asculus Hippocastanum. Mr. Woodward adds: "After the green portion has been removed."

(3) A correspondent at Wells gives me this as a local name for Thistles. See below.

Fish BONE THistue. $\Lambda$ zorrespondent at IIuch elney gives me this as a local name for a 
species of the genus Chamapeuce, natives of the Mediterranea.1 regio ,. allied botr to the Plume Thistles and the true Thistles. Mr. T. W. Cowan tells me that it is the common name for Chamopeuce Casabona. See FisH Bones.

FIsHeraran's BAsket. A fairly general name for the Oalceolaria.

Fishwives' Basker. A correspondent at Colyford (Devon) gives this variation of the above name for the Calceolaria.

Five - FiNGer - Grass. Creeping Cinquefoil. Potentilla reptans, so called from its five leaflets.

Five Fingers. Cinquefoil, Potentilla.

FJaAg. A name given to a number of different plants having sword-shaped leaves, and particularly to the Yellow Iris, Iris Pseudacorus, and the Stinking Iris, I. foetidissima. Dr. W tson says "Generally and truly applicd to Iris Pseudacorus."

Flaggers. A correspondent at Stalbridge gives me this as a local variation of the above name.

Flag LILY. Yellow Iris, Iris Pseudacorus.

FlaG SEDGE. A correspondent at Hawkchurch (Devon) gives me this as a local name for the Yellow Iris, Iris Pseudacorus. Ir. Watson writes "I doubt this. It seems more probable to be given to a sedge, Carex riparia, often associated with Flags."

Flaje Clmber. A correspondent at Bloxworth (Dorset) gives me this as a local name for the Nasturtium, Tropoeolum speciosum.

Flaute Flower. (1) The Torch-lily or Red Hot Poker, Tritoma uvaria.

(2) Correspondents at Yeovil and at Ansty (Dorset) give it as a local name for the Phlox.

(3) Rev. H. N. Ellacombe gives it as an old name for the Pansy, Viola tricolor.

Flaming Sword. A correspondent at Plush (Dorset) gives this as a local name for the FLAME FLOWER.

Flanner, Flannel Flower (or Leaf). Great Mullein, Verbascum Thapsus.

Flannel Petwicoats. A correspondent at Winsham gives this as a local name for the Great Mullein, Verbascum Thapsus. See above.

FlaP DICK, FLAP DOCK, OR FLAPPY DOCK. The Foxglove, Digitalis purpurea. Mr. F. T. Elworthy says " Like a dum'ldary in a flappydock" is a common simile to deseribe a busy, bustling, fussy, noisy person.

Flax Mountain. (1) Mr. J. C. Mansell Pleydell 
gives this as a Dorset name for the Corn Spurrey. Spergula arvensis.

(2) The usual English name for the Dwarf, Fairy, Mountain, or Purging Flax, Linum. catharticum.

Flaxweed. Yellow Toadflax, Linaria vulgaris.

Flatabane. A general English name for various species of Pulicaria, Inula, Erigeron, and Conyza, the powerful smell of which is supposed to drive away fleas. Dr. Watson tells me that the name FLEABANE used by itself is more definitely used for Pulicaria dyssnterica.

Fleas AND LICE. A Bruton correspondent gives me this as a local name for the Ivy-leaved Toad-flax, Linaria Cymbalaria.

Flesh AND BLood. The name of a certain kind of apple (Devon).

FLeUR DE LUCE (OR LYS). Yellow Iris, Iris Psendacor s. Probably the Stinking Iris, $I$. foetidissima, also, but I have no record of this. See FLOWER DE LUCE ; both names are, of course, a corruption of Fleur de Lis, a French name for the Iris.

FutbBerty GibBet. A correspondent at Wells gives me this as a local name for the Common Mallow, Malva sylvestris.

Fintrweed. Feverfew, Chrysanthemum Parthenium. Rev. Hilderic Friend says "A name which has apparently nearly died out, but which was common in South Devon some years ago as the designation of the Feverfew."

Flock. A very common conuption of Phlox.

Flop-A-Dock, Flops, or Flop Top. The Foxglove, Digitalis purpurea (West Somerset and Devoun).

Flora's PaINT-BRUsh. A Dorset correspondent gives me this as a $x$ ame for certain cultivated species of the genus Cacalia, plants belonging to the Aster family, and natives of America and Asia. Mr. T. W. Cowan writes me "I do not know any Cacalia called by this name unless it is meant for $C$. coccinea, commonly called Scarlet Tassel Fiower. A Californian plant, Castilleia parviflora, gous by the name of Indian Paintbrush and Scailet Paint-brush, but this belongs to the Figwort family."

FLower DE LUCE. An old English name for the Iris, both the Yellow (Iris Pseudacorus) and the Stinking ( $I$. foctidissima). See FLEUR DE. LUCE.

Flower Flames. A Taunion coirespondent gives me this as a local name for the Nasturtium, Tropceolum speciosum. 
Frower of an Hour. Several correspondents send me this as a ame for the Mallow, Malva sylvestris. This would appear to be due to confusion. Rev.H. Friend says :- "Another species of Hibiscus is the Venice Mallow, which is a native of Italy and Austria, bears a purple and yellow flower, and has long been known in our English gardens as Mallow of an Hour or Good Night at Moon."

Flower of Bristowe (i.e. B istol). An old name for the cultivated Scarlet Lychnis or "Nonesuch," Lychnis chalcedonica. The Bristol Naturalists' Society's Proceedings for the year 1909 (pub. 1910) contained a most interesting paper with regard to this plant and the origin of its local name by Miss Ida M. Roper, F.L.S. 1 understand that shortly after the publication of this paper the then new University of Bristol adopted this flower as its emblem.

FLower of SPRING. (1) Several young people in different parts of Somerset send me this as a popular name for the Daisy, Bellis perennis.

(2) In view of the above it is perhaps worth recording that the Primrose has the honour of being called the "Flower of Spring " in nearly a dozen different languages.

Flower of THE AxE. The Rev. Hil?eric Friend gives this as a name applied by the country people about Axminster to the rare Lobelia urens, which, he tated, is found in Britain only near that town, but several correspondents tell me it is found also in Dorset and Co nivall.

FLOWER OF THE SUN. A correspondent at Camerton gives me this as a local name fo: the Myrtle, Myrtus communis.

FLUE BRUshes. A correspondent at Mells gives me this as a local name for the Great Reedmace, Typha latifolia, more often called BULRUsH.

FLUFF WEed. Great Mullein, Verbascum Thapsus (Stalbridge).

FLUFFY BUTTONs. A Taunton boy, attending Sex $y$ 's School, gives me this as a Taunton name for tho Sallow. Dr. Watson says" Botb Salix caprea and $S$. cinerea are almost certainly meant."

Fluffr PUfer. Mrs. Lansdowne, of Over Stowey, gives me this as a local name for the seed-head of the Dandelion, Taraxacum officinale.

FLY ANGels or FLY-AWAYs. A Yeovil schoolboy gives me these as local names for the seeds of thr Sycamore, Acer Pseudo-platanus. See FlyING ANGELS.

FLY OATCHER. (1) A number of young people in the Axminster district give me this as a local name for the Sundew, Drosera. 
(2) Corcespondents in several different parts of Somerset give this as a local name for the Campion. See Catch Fly.

(3) Miss Audrey Vivian, of Trowbridge, gives it as a name commonly used in that district for the Wild Arum or Cuckoo-pint, Arum maculatum.

(4) Miss Ella Ford, of Melplash (Dorset) gives this as a local name for the Butterwort, Pinguicula vulgaris.

(5) A correspondent at Dunkerton gives it as a local name for the Orchis, without indicating the species: probably the Fiy Orchis, Ophrys muscifer $a$, whilst two correspondents at Uplyme inform $m$ e the name is in that district given to the Bee Orchis, Ophrys apifera. Dr. Watson writes: - Some confusion bere probably. I suspect that the Fly Orchid is intended in both cases. The likeness of the flower to a fly has caused the name to be mis-applied.

Flying ANGels. Mr. F. R. Summerhayes, of Milborne Port, gives me this as a North Somerset name for the seeds of the Sycamore. See FLX ANGELS.

Fuying Dutchuren. The winged seeds of the Ash, Maple, and Sycamore (Stowey, near Clutton).

Fly Trap. Sundew, Drosera (Horton).

FOAL's Fоот. An old country name for the Colt's-foot, Tussilago Farfara.

FoG. The long grass in pastures which the cattle refuse. This is FoG while green, and BENT or Bonnet when dry (F. T. Elworthy). Old, withered, or spoilt grass (Rev. W. P. Williams).

Fog GRass. Coarse, sedgy grass such as grows in wet places. The distinction is kept between Fog and Fog Grass (F. T. Elworthy).

Fog Wort. Correspondents at Wambrook and Wimborne give me this as a name for the Losser Celandine, Ranunculus Ficaria.

FOLK'S GLovE. This is sent me from all parts of the district as a popular name for the Foxglove, Digitalis purpurea. It is generally stated that the original form of the name was FouK's GLove, i.e. Fairies' Glove, but not all etymologists are prepared to accept this as the derivation.

EOLLY's FLower. Several correspondents at Stalbridge and Stoke Wake (Dorset) send me this as a local name for the Columbine, Aquilegia.

Foor's CAP. A correspondent at Evercreech gives me this as a local name for the Woody Nightshade or Bittersweet, Solanum Dulcamara. Probably owing to the kind of peak formed by the more or less conjoint stamens. 
Fool's CRess. A well-informed correspondent at Leigh (Dorset) gives me this as a local name foi the Watercress, Radicula nasturtium, but I think there must be some confusion. See BrookLINE (2). Mr. W. S. Price (Wellington) tells me he has frequently heard this name applied to Brooklime in order to distinguish it from the edible Water-cress.

Fool's Parsiey. This is the general English name for AEthusa Cynapium, sometimes called the Lesser Hemlock. In "Flowering Plants," by Anne Pratt, revised by Edward Step, it is recorded that some year's ago two ladies in Somersetshire, who ate of it in salad, suffered very scriously, though both ultimately recovered. Several correspondents give this name as being applied to Hemlock, Wild Beaked Paisley, Cow Parsley, Hedge Parsley, and other Umbelliferæ, but probably in most cases they really mean the plant mentioned above, and I have not thought it necessary to set out the names of other plants separately.

Fool's Watercress. Procumbent Marshwort, Apium nodiflorum. See BROOK LINE (2).

Forgert-ME-Not. (1) Auy species of Scorpior grass, Myosotis; but more particularly the Water Scorpion-grass, IM. scorpioides, which grows on the banks of streams. I believe it was less than 100 years ago that this nome was first given to this gen as of plants in England, although it was the popular name for them in Germany aud Denmark. It was in co.rsequence of the remarkable popularity gained by the now well-known German legend of a knight and his lady love, published about a century ago by Mills in his "Origin of Chivalry," that tris name was given to the Myosotis in England.

(2) De. Prior tells us that for more tha.1 200 years previous to the introdaction of this German legend, the plant which had borne in England the name of Forget-me-not was the Ground Pine, Ajuga Chamapitys, which also bore in Franze and the Netberland; a popular name having the same meaning, which was said to have been give in consequence of the nauseous taste which it leaves in the mouth.

(3) Correspondents in different parts of each of the four counties apply the name to the Germander Speedwell, Veronica Chamcedrys, more generally known as BrRD's Erres. Dr. Prior says this is owing to a confusion originating in the blue colour of the flowers, but what appears to me to be a much more probable explanation is that given under the name SPEEDWELL.

Four-teaved Grass. Herb Paris, Paris quadrifolia.

Four o'Ctock. Dandelion, Taraxacum officinale (Stoke-under-Ham and Axmi ister). Called also 'TWELVE O'ClOCK and ONE O'ClOCK. 
Fox Flops. A West Somenset name for the Foxglove Digitalis purpurea.

Fox's Brush. A correupondent at South Pethorton gives this a'; a local name for the Valoin but does not indiente the species. Mr. T. W. Cowan tells me it is Kentranthus ruber.

Fox's Mouth. A correspondent at Ilminster gives this as a local name for the Monk's-lnood, Aconitum Napell's.

Fox STones. Correspondents at Chewton Mendip and Wimbone give this as a rame for the Orchis, but do not indicate the species. See DOG STONES.

FoxTAسs. (1) A correspondent at 'Thurlbear gives me this as a local name for the catkins of the Hazel, Coryl:is Avellana.

(2) In : .W. Wilts tre name is giren to the crtsin of the Willow, Salix.

(3) A curespoudent at Evershot gives it as a local name $\mathrm{f}$ r the Cbickweed, Stellaria media.

Fox Wort. A Mrartock schoul boy gives me this as a licel name for the Lesser Celandine, Ranunellis Ficaria.

Framboise, or IRAMrboys. Mr. J. C. Mansell Hleyciel gives 1 his as a Dorset name for the Raspberry, $R$ bus idaus, and quotes "MIy Lord of Silisbury tolime tbat in Cranborne Chase there grew raspes commonly, and in grent plenty, as is that the comintry perple called thm framboises, wich is the Frei ch wi rd frrthrm." (Written about 1638, and quoted in Notes and Queries Ser. iv., vol. 1, p. 532).

FrECKLED FACE, A correspondent at Dowlish Wake gives $m$ ? this as a lucal name for the Cowslip, Primula veris.

French, A correspondent at Wellow gives me this as a local name for the S infcin, Onobrychis vicicefolia. See French Grass. (1).

French Bfans. Mrr. Elworthy says: "Applicd by cottagers to the dwalf varieties only. The climbing runners are always Kidney Bears, fr $m$ th? e l inr and $s h n^{2}$ of th seed," Dr. Watson writes "So far as my experience goes applied indiscriminately to any Kidney Bean. In some parts where Kidney Beans or Scarlet Runners are grown the former is used when grown for the kitchen, the latter when grown as a flower. I do not think this discrimination applies to the South of England at all, but only to districts where the climate is not usually suitable for growing Kidney Beans for eating."

French GoAT's BEARd. A correspondent at Stnckland (Devon) give: $m$ ? this as a local name for the Hawkweed, Hieraci $\mathrm{im}$. 
French Grass. (1) Sainioin, Onobrychis vicicefolia.

(2) The garden striped Ribbon-grass, Phalaris arundinacea variegata.

- French HoNersuckne. (1) The plant that is usually known by this name is Hedysarum coronarium.

(2) Mr. W.S. Ptice tells me the name is applird to a cultivated variety of Honeysuckle bearing numerous clusters of deep orange coloured flowers. The florets are smaller, and each cluster: contains more than the common wild variety.

(3) Several young people at Sampford Arumdel give me this as a locil name for the Lupine, Lupinus.

Frenchanan's Darling. A correspondent at Martock gives me this as a local name for the Mignonette, Reseda odorata.

French NUT. A name very commonly used in Somerset and Devon for the Walnut, Juglans regia. Holloway adds, "great numbers of tris fruit b iing imported from France."

French Pink. (1) Same as Indian Pink, Dianthus chinensis. (Devon).

(2) Sea Pink or Thrift, Statice maritima

French Poppr. A correspondent at Widworthy (Devon) gives me this as a local name for the Great Mullein, Verbascum Thapsus.

French Pops. Mr. F. T. Elwortry says : "The small purple Gladiolus. The flowers are in shipe much like Pops, i.e., Foxgloves, They are very common in cottage flower knots."

French Primrose. A correspondent at Holditch (near Crard) gives me this as a local name for the Polyanthus.

French Sparrow Grass. Accóding to Dr. Prior this is the name under which are sold in the Bath market, to be eaten as Asparagus, the sprouts of the spiked Star of Bethlehem, Omithogalum pyrenaicum.

French VIolets. A correspondent at Watchet gives me this as a lncal name for the "Ni'get. Cam panula, but Dr. Watson tells me that Wahlenergia hederacea does not occur at Watchet.

French WrLow: Rose-bay (Willow-rerb), Epilobium angustifolium.

Friar's CAPS. Monk's-hood, Aconitum Napellis, from its upper sepals resembling a friar's cowl.

Fried CANDLEsticks. This curious name for a wild Orchis, most probably the Early Purple, Orchis mascula, is sent me by a couple of correspondents at Winsham. See CANDLESTICKS (1). 
Mr. G. T. Onions writes me :- "What the Fried is I can't guess, but the Canduesticks has, I think, come out of KandLEGostes or some such form which is in Gerarde's Appendix (according to Britten \& Holland), together with GANDERGosses, of which it may be a further corruption." See GANDER GAUZE.

FrIED EGGS. I wonder that so appropriate a name is not more commonly given to the $\mathrm{Ox}$ eje, Chrysanthemum Leucanthemum. I have received it only from a correspondent at Chilton Polden and Mir. Edward Vivian, of Trowbridge.

Frith. Brushwood (Rev. W. Barnes, Dorset).

Frog BItes. The Frog Bit, Hydrocharis Jorsus-rance (Chew Magna).

Frog's Foot. Correspondents at Yeovil and Rodney Stoke give me this as a local name for a species of Crowfoot, Ranunculus.

Frog's MEAT. (1) Toadstools (Wilts).

(2) Leaves of the Arum, Arum maculatum (Dorset).

Frog's Mouth. (1) Mrs. Day, of North Petherton, gives me this as a Somerset name for the Early Purple Oichis, Orchis mascula.

(2) A correspondent at Sherborne gives it as a local name for the Snapdragon, Antirrhinum majus.

FUller's Thistle. The Fuller's Teasel, Dipsacus fullonum, which is grown in some parts of Somerset.

Funny Faces. A correspondent at Evercreech gives $m$ this as a local name for

(1) The Pansy, Viola tricolor.

(2) The Nasturtium, Tropocolum speciosum.

Furniture. Several correspondents at South Petherton give me this as a local name for the Box, Buxus sempervirens. Compare CHAIRS AND TABLES.

Fuzz or Fuzzen. Furze: Gorse or Whin, Ulex europoeus.

When the Fuzz is out o' blossom

Kissing's out of fashion.

Dr. Watson writes:- "It is not generally known that there is more than one species of Ulex. $U$. europxus is the common large Gorse and flower's most profusely from January to April. Other species Western Gorse ( $U$. Gallii) and Dwarf Furze ( $U$. minor) come into flower much later on, and flower most profusely about September and October. It is a curious coincidence that Gorse is aiways in bloom during the months with an $R$ in their names. From January to April flowers are plentiful. From May to August late flowers of the Common Gorse and early flowers of the other species may be found." 
FUZz BALL. A puff ball, Lycoperdon bovista and other species of Lycoperdon (Dorset and Wilts).

GALL OF THE EARTH. A correspondent at Oake sends me this as a local name for the Commion Centaury, Centaurium umbellatum. See EARTH GALL.

Gallow Grass. Cant name for hemp-also called Neckweed-as furnishing halters for the gibbet. Cannabis sativa.

Gallows Froit. A correspondent at Dowlish IV ake gives me this as a local name for the Fuchsia.

GaNder GaUze. A Wiltshire name for the Early Purple Orchis, Orchis mascula. Mr. Edward Vivian tells me that in the Trowbridge district the use of this name is almost aiways used. The plant is often called Goose AND GosLINGS - from a fancied resemblance of the flowers to the shape of little goslings. See Frind CANDLESTICKS and Gandergosses.

Gandergosses.-Mr. T. W. Cowan tells me that this and Goose AND Gostrngs are old names for the Green-winged Orchis, O. morio, and be has not known them applied to $O$. mascula, ulthough this may be the case in Wiltshire, as st gea in the paragrapl: above.

GaNder Grass. An old name for the Silverweed, Potentilla Anserina, the silvery white leaves of which may be found on almost every road side. Sometimes called GooseweEd. The specific name is from Latin Anser = a goose, and was given in consei uence of that bird being fond of the plant.

Gand Gostrngs. Early Purple Orchis, Orchis mascula (N.W. Wilts).

GANG FLower or GANG WEed. The Milkwort, Polygala vulgaris, from its blossoming in Gangweek, three days before the Ascension, and being employed to make garlands used in the Rogation proces ions; for the same reason it was formerly called Cross, Rogation, or Procession Flower.

Gape Mouth. A mucl less general form of Gap MoUTH, which see.

GAPING JACK. Yellow Toadflax, Linaria vulgaris (North Oheriton).

Gap Modth. (1) A common name for the Snapdragon, Antirrhinum majus.

(2) Yellow Toadflax, Linaria vulgaris.

(3) The Yellow Monkey Flower, Mimulus Langsdorffii; also the cultivated species of Mimulus, including the Musk.

(4) Several young people at Sampford Arundel give it as a local name for the Foxglove, Digitalis purpurea. 
G.ARDExER's GARTERs. The garden striped Riblion Grass, sometimes called Frexch Grass. Phalaris arundinacea variegata.

Gardex Gates. London Pride, Saxifraga umbrosa. The old name used to be "Kiss me Love at the Garden Gate" : this was contracted to "Garden Gate." Such names are, perhaps, mote frequently given to the Pansy or Heartsease, Diola tricolor.

F GARDEN MAY. The School Mistress at Beaminster gives me this as a local name for the Lazristimus.

GARDEN PATIENCE, A correspondent at Winscombe gives me this as a local name for the Monk's Rhubarb, Rumex alpinis, formerly used for medicinal purposes. It has been wittily suggested that the name "Patierce" was doubtlese given to thi: Dock oo ascount of the length of time required for it. to eflect a cure of the malady for which it was prescribed. Dr. Watson writes "I think there is often confusion here with Butterburr; I know of a few cases. The plant mentioned is obviously a garden one, and is probably the true plant. Bistort is often known in the North as PAYshuN or PAtLence Dock, dêrived from PAssion Dock, since the leaves of the plant appear about Passion week."

Gaskins or Gascoignes. A correspondenit at West Coker gives me this as a local name for the Wild Cherry, Prunus avium. It bears a similar name is $\mathrm{Ke} t$, and probably in other parts of the country.

GAUZE FLOWER. The "fern-saver" of the gardeners, Gypsophila paniculata; also known as CHALK PLANT.

GFAN. A general Englich $\mathbf{n}$ me for Pr $n \cdot s$ avium. Lady Francis Oecil tells me GEAN is a Scots name supposed to be derived from Elinor of Guienne, who brought this Cherry from France

GELC ALFRED. This is an interesting $t \mathrm{x}$. mple of the way in which names get corrupted. A correspondent sends it as a li cal name for the Wallflower, Cheiranthus Cheiri. The nime is obviously a corruption of GruAwFEP, which see.

GELLIFORs. A corresponitent at Minsh m

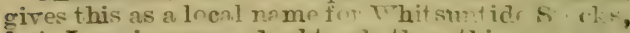
but I am in some doubt whether this means a species of .1/atthiola or the White Double Rocket, Hesperis matronalis. See GrlAwFen and also under WHISUNTIDE.

Genthenan's Butrons, Several correspondents at Paulton give me 1 his as a local rame for the garden Double Daisy, Bellis.

Gentueman's CAP AND FrHLs. A schnol girl at Paulton gives me this as : 1 cal $n: m$ for the Lesser Celandine, Ranunc l s Ficaria. 
Genti enax's Finger. Cuckoo-pint, Amu maculatum (N.W. Wilts).

Gentleman's Pincushion. A Somerton :orres pondent gives me this as a local name for the Field Scabious, Scabiosa arvensis.

Gentlemax's Purse. Quite a number or young people at Paulton give me this as a local name for the Shepherd's Purse, Capsella Bursapastoris.

Gentuman Tatrors. A correspondent at East Lulworth (Dorset) gives me this as a lccal name for the Pansy, Viola tricolor.

Gentlemen Axd Ladies. (1) A Crewkerne lady gives me this as a local name for the Wild Pansy, Viola arvensis.

(2) Dr. Watson tells me that this name is occasionally used instead of LORDS AND LADIES for Arum maculatum.

Gentlemex's and Ladies' Fingers. Cuckoopint, Arum maculatum (S.W. Wilts).

Gextuenex's Caps. Several correspondents at. Long Sutton give me this as a local name for tre Tulip, Tulipa Gesneriana.

Germaxs AND EngLish. A correspoident at Watchet gives me this as a lozal name for the Celery-leaved Crowfoot, Ranunculus sceleratus.

GHost Grass. Mr. W. C. Baker, late of Ira ansel, gives me this as a local name for Pampas Grass, Gynerium argenteum.

Ghost Poppr. A correspondent at Stockland (Devon) gives me this as a local name for the shirley Poppy.

Grbbles. Onions grown from bulbs (Wilts). Jennings and Holloway spell the name GIBBOL; and define it as a sprout of an onion the second year. Compare CHIBBLES.

Groksy. A dried nettle (East Somerset). A simile frequ ent ly beard in that part of the country is "Zoo light's a gicksy." Also the stalk of the Wild Parsley, ont of which primitive pipes were made. See Kex and KECKsy.

GIDDY GaNDER. The Early $P$ urple Orchis, Orchis mascula, and the Green-winged Meadow Orchis, Orchis morio, and other comnon speries of Orchis, are so called in the Vale of Blackmore., See Goosey Gander.

Giggary. Dafiodil. Narcissus Pseudo-Narcissus (Devon). Edward Capern, the poetwriting in the Western Times, March 29th. 1879 , quoted one as saying: "Don't bring they GIGGARYS int o the house : vor if 'ee du, ex shaant ha' a single chick.'

Grawfer. It wo sld be easy to write a column on this name, which is spelt and pronounced in 
a great variety of ways, from GELL ALFRED and GELLIFors (see above) to JELLY FLOWER or JULY FLOWER, The form GH.AWFER is adopted by Jennings, F. T. Elworthy, and Rev. W. P. Williams. The name is derived from the French giroflé, which, with the Italian garofilo, goes back to Caryophyllum, a clove, and refers to the spicy odcur of the flower so mamed (the Clove Pink), which seems to hare been used in flavouring wines. Dr. Prior tells us "The name was originally given, in Italy, to plazts of the Pink tribe, espccially the Carnation, but has of late years, in England been transterred to several cruciferous plants, such as the Wallflower and Stosk. The Gilliflower of Spenser and Shakespeare was, as in Italy, Dianthus Caryophyllus ; that of later writers and gardeners, Matthiola and Cheiranth:s" (Britten \& Holland). Holloway saye the name GIIAWFER is corrupted from Gilly Flower, which is corrupted from July Flower-in which, I believe, he is quite wrongand be describes it as a general name in Somerset for plants of the Dianthus tribe, many of which flower in July. Scores of correspondents have sent me this name in one form or another, and bave applied it to a number of different flowers wlich I do not co usider it necessary to set out in detail, but speaking broadly, the great majority of those who spell the name GHLIFLowER apply it to the Wallflower (except in Dorset), whilst the majority of those who gire some such form as GuAwFER or Jillofwer apply it to one or other of the Stocks.

GII Cup or GIIL Cup. A common name for Buttercups geserally, on account of their cup-like shape and the gilt-like gloss of their petals. Judging from the lists sent me from all parts of the district, the name is most frequently applied to

(1) The Bulbous-rooted Buttercup, Ranunculus bulbosus (particularly in Dorset).

(2) Meadow Crowfoot or Buttercup, Ranunculus acris.

(3) Marsh Marigold, Caltha palustris.

(4) Lesser Celandine, Ranunculus Ficaria.

GIID, GILDED, or GHDING Cup. Same as GII CUP.

GILL. A corresponde it at Rodden (near Frome) gives this as a local name for the Ground Ivy, Nepeta hederacea.

GILL-ALE. Halliwell give this as a Devonshire name for the Ground Iry, Nepeta hederacea. It is also known as AleHoof, and according to Gerard it was formerly used in the making of Ale.

GHLAwFer, See GILATfER.

Gmu Creep by the Ground. An old Somerset name for the Ground Ivy (see GHI. ), given me by a Yeovil correspondent. 
Gill Cup. See GIL Cup.

GIll go on (or Over) The Ground. An old English name for the Ground Ivy (see GuLL) sent $m_{3}$ by sevaral correspondents as being still in use.

Gilliflower. See also Gillivfer.

(1.) Most generally the Wallfower, Cheiranthus Cheivi (particularly in Som set and in the North).

(2) Various species of Stcck, Matthiola (particularly in Dorset). Dr. Watson telis me the name is not applied to the Ten-week Stock, but to those which stand the winter.

(3) Clove Pink, Carnation, Sweet William, and othor species of Dianthus.

(4) Dr. Watson tells me the namo is sometimes given to the Cuckoo Flower, or Lady's Smock, Cardamine pratensis, probably owing to co fusion.

(5) In Devon, Polemium caruleum and $P$. album, commonly known as JACOB's LADDER.

(6) S sveral young people at Long Sitton give this as a local name fur the Garden In mone.

Gil RuN AloNG THE GROUNd. In old English name for the Ground Ivy (see GIIL), sent me by several correspondents as being still in use.

GHLY. A correspondent at Doulting gives me this as a local name for the Wallflower. Cheircuthus Cheiri, See GHAwFER and GIIIFLOTwER.

GILOFFER. See GHATFER and GILLIFLOWER. Rev. Hilderic Frjend says: "In Scmersetshire the word GHOFFEn is still used in speakirg of the Ten-week Stock, while in North Devon the Wallflower is so called."

Gilt, Gited, Griten, GHting, or GHty Cup. Same as GII CUP, which see.

Ginger. Mrs. H. Day, of North Pethertón, gives this as a name for the Biting Stonccrop, Sedum acre, often called WALL PEPPER.

GINGEr Flower. An Evercreech schnel boy gives me this as a local name for the stcck, Matthiola.

Gipsies. (1) Herb Robert, Gerani:m Robertianum. See GIPsy Fuower (1).

(2) Mr. J. Woodward, of Bridgwater, gives me this as a local name for the Hedge IIustard; Sisymbrium officinale.

GIPsy. (1) Several correspondents at Nettlecombe give me this as a local name for the Ribwort Plantain, Plantago lanceolata.

(2) A jother zorrespondent at Nettleombe gives it as a local name for the Ragwort, Senecio. Jacobaca.

(3) Carnation grass, Carex panicea, "because it turns so brown "N.W. Wilts).

(4) Fisld Woodrush, Luzula campestris (West wilts). 
GIPsy Beans. Seeds of the Vetch, Vicia (Draycott).

Gipgy Curtatns. Wild Parsle j, Anthrisci:s sylvestris (Ilminster).

GIPsy DaIsy. (1) The Ox-eye, Chrysanthemum Leucanthemum (Barrington and Beaminster).

(2) The Scentless Mayweed, Matricaria inadora (Bridgwater).

(3) A Muchelney school boy gives it as a local name for the Field Scabious, Scabiosa arvensis, more commonly called GIPSY RosE.

GIPSY Flower. (1) The plant mosi commonly called by this name in tbe area covered by this list is the Herb Robert, Geranium Robertianum.

(2) Wild Parsley, Anthriscus sylvestris.

(3) Hound's Tongue, Cynoglossum officinale.

(4) Correspondents at Lydford-on-the-Fosse and Washford apply this name to the Red Campion, Lychnis dioisa.

(5) A correspondent at Babcary gires it as a local vame for the Ragged Robin, Lychnis Floscuculi.

(6) A correspondent at Martock apjlies it to ihe Hemlock, Conium maculatum.

(7) A correspondent at Keinton Mandeville gives it as a local name for the Field Thistle, Cnicus arvensis.

(8) A correspondent at Leigh (Dorset) gives it as a local name for the "Deadly Nightshade," which is probably a mistake for the Woody Nightshade, Solanum Dulcamara.

(9) In N.W. Wilts the name is given to the Meadow Crane's-bill, Geranium pratense.

GIPsy LACE. Correspondents at South Pethertoll give me this as a lceal name for

(1) Wild Parsley, Anthriscus sylvestris.

(2) Water Bedstraw, Galium palustre.

GIPsy MaIDs. A correspondent at Martock gives me this as a local name for the Red Spur Valesian, Kentranthus ruber, more commonly known in that part of the county as KISS-MEQUICK.

Grpsy Pras. Common Vetch, Vicia sativa.

Gipsy PINK. A correspondent at Creech St. Michael gives me this as a local name for the Striped Ca:nation-a va iety of Dianthus Caryophyllus.

Gipsy Primrose. Red Polyanthus, Primula (Wookey).

Gipsy Rose. (1) The Field Seabious, Scabiosa arvensis.

(2) The Devil's Bit, Scabiosa Succisa.

(3) The Garden Scabious, Scabiosa atropurpurea.

GIPsy VroLET. (1) Correspondents at Long Sutton and Stalbridge give me this as a local 
name for the pink variety of Violet.

(2) An Evercreech school-boy tells me the name is given in that district to the Dog Violet, Viola canina.

GIPsy's BACCY. (1) Two school-boys at Evercreech give me this as a local name for the Common Sorrel or Sour-dock, Rumex Acetosa.

(2) A correspondent at Corfe Mullen (Dorset) gives it as a local name for the Wood Sage, Teucrium Scorodonia.

GIPsy's BrIDE. A correspondent at Winsham gives me this as a local name for the Fuchsia.

GIPSY's CURTAINs. Common Hemlock, Conium maculatum (Ilminster).

GIPsy's FLowEr. Several young people at Oakhill give me this as a local name for the "Wild Sweet Pea," by which they probably mean the Wild Everlasting Pea, Lathyrus sylvestris.

GIPSY's GIBBLES. Garlic, Allium ursinum (Doulting). "Gibbles " or "Chipples" is a well-known. Somerset name for young onions, and is here applied to the Garlic on account of its onion-like smell.

GIPsy's HAT. Lesser Bindweed, Convolvulus arvensis (Stoke-under-Ham).

GIPSY'S LACE( or LACES). Cow-parsnip or Hogweed, Heracleum Sphondyium (Yeovil).

Gipsy's Moner. The Marsh Marigold, Caltha palustris (Thurlbear).

Gipsy's OnIONs. Garlic, A'lium ursinum.

GIPSY'S PARsLery. (1) A correspondent at Thurlbear gives this as a local name for the Wild Beaked Parsley, Anthriscus sylvestris.

(2) A correspondent at Hatch Beauchamp gives it as a local name for the Herb Robert, Geranium Robertianum.

GIPSY's RHUBARB. (1) The Burdock, Arctium majus.

(2) The Butter-bur, Petasites ovatus.

Gipsy's Sage. Wood Sage, Teucrium Scorodonia (Melplash, Dorset).

GIPSY'S SOAP. A correspondent at Chelborough (Dorset) gives me this as a local name for the Knotted Figwort, Scrophularia nodosa. Dr. Downes wites "More probably the Soapwort, Saponaria officinalis, the leaves of which were formerly used as a substitute for soap." See SOAP-IEAVES.

Gipsy's 'ToBAcco. (1) A Dorchester lady gives me this as a local name for the Wild Clematis or 'Traveller's Joy, Clematis Vitalba, of which the dried stems are smoked by school-boys. IIurray, in his "Flora of Somerset," states that 
the leaves of the Clematis are somctimes used as a substitute for tobacco.

(2) Two Evercreech school-boys give it as a local name for the Common Sorrel, Rumex. Acetosa. See Gipsy's BAccY.

GIPsy's UMBRelli. Several correspondents at Wembdon give this as a local name for the Wild Parsley, Anthrisc:s sylvestris.

GIRIs. The short-styled (thrum-or rose-eyed) Primroses, Prim?la vilgaris. The long-styled or pin-eyed flowers are called Bors.

Girls' Delight. Southernwood, Artemisia Abrotanum, mrre generally knomn as Bor's LovE, which see.

GIRLs' Love. Rosemary, Rosmarinus officinalis.

GIx or Gixy. Britten gives this as an East Somerset and WVilts name for the Kex of Hemlock, and adds "Kex, Keck, Kecks, Kiks, Kecksey, dc., are all applied to different members of the Carrot family." See also GICKsY.

Gladdox, Gladwry, Gladix, Glader, or GLADDX. The Stinking Iris, Jris fotidissima. Although Fenning says that this is a general uame for plants with a broad blade, from Lat. Gladius, a sword, it appears at the present time in this district to be confined to the Iris. Mr. T. W. Cowan, F.L.S., tells me that in Norfolk the name GLADDON is given to the Cat's-tail, Equisetum.

GLastonbury Thorx. Mr. Elworthy describes this as " a variety of Whitethorn, which puts out rather a sickly-looking white blossom in winter, and is said to blossom on Christmas Day. Its name is from the legend of Joseph of Arimathrea, who planted his staff on Wearall Hill at Glastonbury, whence sprung the famous thorn." The botanical name is Cratagus Oxyacantha procox.

GLELIING STAR. Quite a number of young people at Paulton give me this as a local name for London Pride, Saxifraga umbrosa.

GLoBes. The Common Globe-flower, Trollius europor's; rarely found wild (never in the area covered by this list), but scmetimes seen in cottage gardens. Dr. Watson writes "I think the 'Globe-flower' of cottage gardens is often a double-flowered Ramunc,l: $s . "$

GLormess. The Moschatel, Adoxa Moschatellina; this popular name is the English equivalent of the Greek generic name Adoxa.

GNAT-FLowER. A correspondent at Meriott. gives me this as a local name for the Knapweed, both Centarrea se ios and $C$. nigra.

GOAT LEAF. A correspondent at Long Load gives me this as a local name for the Honeysuckle 
or. Woodbine, Lonicera Periclymenum. See GoAT's LEAF.

GOAT'S BEARD. (1) This is the general name for the Salsify group, and is the English equivalent of the generic name Tragopogon. It would not be inclucled in this list but for the fact that several correspondents in Devon and Dorset give it as a local iame for

(2) The Meadow-Sweet, Spirce Ulmaria.

(3) A correspondert at Queen C'amcl gives it as a local name for the Endive, Cichori: $m$ Lindivia.

GoAT's Foot. (1) The Schoolmaster at Batcombe gives me this as a local name for the Common Rock-rose, Helianthemum Chamacistus.

(2) A correspondent at Draycott gives it as a local name for the Yellow Goat's-beard, Tragopogon pratense.

(3) A correspondent at Axminster gives it as a lccal name for the Gout-weed, It gopodirm Podagraria.

Dr. Watson considers that 2 and 3 are both mis-applications, due to a similarity in sound of the first pait if the rame.

GOAT's LEAF. Correspondents at Evershot and Stockland (Devon) give me this as a lccal name for the TVoodbine or Honeysuckle, Lonicera Periclymentm. This plant is placed by botanists in the crder Caprifoliaces - a Latin name which means "Goat's leaves."

GOAT WEED. (1) Goutweed, E'gopodium Podagraria.

(2) Bleck Bindweed, Polygon' m Convolv lus (N.W. Wilts).

Go-cuPs (i.e., GOLD-CUPS). (1) Buttercups in general, but perhaps more particularly the Meadow Crowfoot, Ranunculus acris.

(2) The Marsh Marigold, Caltha pal, stris.

(3) The Lesser Celandine, Ranuncul s Ficaria.

Gon Almighty's BREAd AND Chense. A common name in West Somerset and other parts covered by this list for the Wood Sorrel, Oxalis Acetosella.

GOD Almighty's Flowers. A correspondent living near Axminster gives me this as a local name for the Bird's-foot Trefoil, Lotus corniculatis. See GOD's Frigers AND Thumbs.

GoDfathers AND GODMIOTHERs. Mrs. H. Day, of North Petherton, gives me this as a local name for the Pansy, Viola tricolor. Compare STEP. MOTHER.

God's FINGERs AND Taunbs. Correspondents at Bradford-on-Tone, Culmhead, and elsewhere send me this as a local name for the Bird's-foot 'Trefoil, Lot:s corniculatıs. See GOD ArmigHTY's FLOWER.

GouD. (1) The Bog Myrtle or Sweet Willow, Myrica Gale: abundant in the boggy moors of 
Somerset. Called gaule by the old herbalists.

(2) Also applied to the Corn Marigold, Chrysanthemum segetum.

(3) Dr. Watson writes "GoLD is a fairly general name for various Marigolds, including the garden Calendula officinalis.

Gold BALls. Mr. T. W. Cowan, F.L.S., gives me this as another name for Buttercups, Ranunculus.

Gold BELLs. Daffodils, Narcissus PseudoNarcissus (Trowbridge district).

GoLd Cups. Buttercups generally. Holloway gives the Meadow Ranunculus, $R$. acris, and Jennings $R$. bulbosus. See Go-cuPs.

Gold Dust. (1) Biting Stonecrop, Sedum acre.

(2) Yellow Alyssum, Alyssum saxatile.

Golden BALLS. (1) A name commonly used in West Somerset for the Guelder Rose, Viburnum Opulus.

(2) A correspondent at Bloxworth (Dorset) gives it as a local name for the Globe Flower, Trollius europaeus. Dr. Watson tells me it is so used in the North of England. See GLOBES.

(3) A variety of apple.

GOLDEN BELLS. A Martock school-boy gives me this as a local name for the Cowslip, Primula veris.

GoLden Blossom. Rev. Hilderic Friend gives this as a Devonshire name for the Creeping Cinquefoil, Potentilla reptans.

GOLDEN ButTER. A correspondent at Leigh (Dorset) gives me this a local name for the Lesser Spearwort, Ranunculss Flammula.

Golden Buttercup. A correspondent at Axbridge gives me this as a local name for the Marsh Marigold, Caltha palustris.

Golden Buttons. Common Tansy, Tanacetum vulgare (Axminster).

Golden CAP AND FriLl. A correspondent at Paulton gives this as a lccal name for the Lesser Celandine, Ranunculus Ficaria.

GOLDEN CARPET. A correspondent at Radstock gives $m$ this as a local name for the Yellow Stonecrop, Sedim acre.

Golden Chatn. (1) A very general name for the Laburnum, Laburnum vulgire.

(2) A number of correspondents at South Petherton and Mells and one at Leigh (Dorset) give it as a local name for the Broom, Cyiisus scoparius, which belongs to the same genus as the Laburnum.

(3) Mr. F. T. Elworthy gives it as a common name in West Somerset for Ramunculus globosa. 
Several botanical friends tell me this name is unknown to them, and suggest that Mr. Elworthy referred to the Common Buttercap, $R$. bulbosus.

(4) In S.W. Wilts the name is sometimes given so the Meadow Vetchling, Lathyrus pratensis.

GOLden CORNFlower. The Corn Marigold, Chrysanthemum segetum.

Golden Cups. (1) A name given to Buttercups generally; Rev. Hilderic Friend names Ranunculus acris in particular, and Mr. F. T. Elworthy says $R$. globosa is commonly so-salled in West Somerset.

(2) The usual name in West Somerset for the Marsh Marigold, Caltha palustris. I have it also from Bridgwater and other districts.

(3) The Lesser Celandine, Ranunculus Ficaria (Wembdon). See Go-cUPS.

Golden DAIsY. A correspondent at Babcary gives me this as a local name for the Wild Marigold, Chrysanthemum segetum. It is also given to the garden Marigold, Calendula officinalis.

GOLDEN DRAP. A well-known variety of plum (F. T. Elworthy).

Golden DRINKING Cu . A Yeovil schoolboy gives me this as a local name for the Lesser Celandine, Ranunculus Ficaria.

GoLDEn Drops. A correspondent at Camerton gives me this as a local name for the Cowslip, Primula veris.

Golden Dust. (1) Yellow Alyssum, Alyssum saxatile.

(2) Yellow Bedstraw, Galium, verum (Wookey).

(3) A Martock school-boy gives this as a locaI name for the Golden Rod-probably a cultivated variety, as the Wild Golden Rod, Solidago Virgaurea, is rather local in its occurrence, and is very rare in this district, even if it is found here at all.

GOWDEN FEATHER. A very general name for the Pyrethrum.

GOLDEN FLOWER. (1) A fairly general name for the Corn Marigold, Chrysanthemum segetum.

(2) A correspondent at Wookey gives it as a local name for the Silverweed, Potentilla Anserina.

Goupen GLow. A correspondent at Babcary gives this as a local name for the Golden Rod, See note to GoLDEN DUST (3).

Golden Gratn. Great Mullein, Verbascum Thapsus (Devon).

GOLDEN KING-CUPS. The Marsh Marigold, Caltha palustris.

GoLden KNoв. The Marsh Marigold, Caltha palustris. 
GoL EN Locks. (1) Several young people at Brompton Regis give me this as a local name for Buttercups of various kinds. See GoudLOCKS (1).

(2) A correspondent at Membury (Devon) gives it as a local name for the Laburnum, Laburnum vilgare.

Golden Midnights. A school-girl at Otterhampton gives me this as a local name for "Fingers and Thumbs" Lotus corniculatus.

GoLden Moss. A correspondent at Queen Camel gives me this as a local name for the Stonecrop, Sedum acre.

GoLDEN NIGGER. A school-girl at Otterhampton gives me this as a local name for the Sunflower, Helianthus annus.

Golden Nob. A variety of apple; a kind of golden pippin (F. T. Elworthy).

Golden Pussies (or Pussy Patar). Goat "Willow or "Palm," Salix caprea.

Golden RAIN. A correspondent at Thorncombe gives me this as a local name for the Laburnum, Laburnum vulgare.

GoldEN RoD. (1) The general English name for Solidago Virgaurea.

(2) Great Mullein, Verbascum Thapsus.

(3) A number of young people at Chew Magna give me this as a local name for the St. John's Wort, Hypericum; a correspondent at Bradfordon-Tone definitely names the Square-stalked species, $H$. quadrangulum.

(4) Several correspondents at Stour Provost (Dorset) give this as a local name for the A grimony Agrimonia Eupatoria.

(5) A correspondent at Stalbridge gives it as a local name for the Broom, Cytisus scoparius.

GOLDEN ROSE. A school-boy at Evercreech gives me this as a local name for the Primrose, Primula vulgaris.

GoLden SEAL. A correspondent at Cutcombe gives me this as a local name for a flower "like the Dandelion, but branched and smaller flowers." Probably the Hawkspeard, C/ epis.

GouDEN SLIPPERs. A school-girl at Charlton Horethorne gives me this as a local name for the Bird's-foot Trefoil, Lotus corniculatus.

GoLdex Sovereigns. A correspondent at Camerton gives me this as a local name for the Silverweed, Potentilla Anserina.

GoLDEn STANDs. A correspondent at Doulting gives me this as a local name for the Buttercup (? Ranunculus acris).

Golden Stars. (1) I have this from many parts of the district as a local name for the Lesser Celandine, Ranunculus Ficaria. 
(2) Quite a number of young people at Brompton Regis give it as a local name for the Primrose, Primula vulgaris.

Goldoen Sun. Several correspondents at Dunster give this as a local name for the Dandelion, Taraxacum officinale.

GoLden TRUMPETs. The Daffodil, Narcissus Pseudo-Narcissus (South Petherton).

GOLDEN WATCH-CHAINS. A correspondent near Ilminster gives me this as a local name for the Laburnum, Laburnum vu!gare.

GOLDEN WATER-LILY. Correspondents at Staple Fitzpaine and in several parts of Dorset give me this as a local name for the Marsh Marigold, Caltha palustris.

Golden Wings. Golden Rod, Solidago Vir-? gaurea (Wembdon).

GoLDHOcks. (1) A fairly general name for the Wood Crowfoot, Ranunculus ariricomus; often given to other Buttercups also.

(2) Aster Linosyris, which is a very rare plant in Somerset. Linnaeus gave it the generic name of Chrysocoma, which is derived from two Greek words, meaning "Golden locks," hence the popular name.

(3) An Evercreech school-boy tells me the name is given in that district to the Marsh Marigold, Caltha pa? ustris.

GoLD KNoBs. A name given to more than one species of Buttercup; a correspondent at Thorncombe gives it as the local name for the Creeping Buttercup, Ranunculus repens.

GowDLOCK. Charlock, Brassica arvensis (Zeals, Wilts).

GoLD LOCKET AND CHAIN. Several young people at Paulton give me this as a local name for the Laburnum, Laburnum $v$ lgare.

Gold of Pleasure. The English name for Camelina sativa, a plant of the Mustard family cultivated for the oil of its seeds. Sometimes called FALSE FLAX and OIL-SEED PLANT.

GOLD SEED. Several young people at Dunster give me this as a local name for the Dog's-tail Grass, Cynosurus cristatus.

Gold Star. Common Avens, Geum urbanum (Evershot).

GoLD WATch. A correspondent at Frome gives me this as a local name for the Largeflowered St. John's Wort, Hypericum calycinum, more commonly called in this district ROSE OF SHARON.

GoLd WaTCH AND ChaIN. Laburnum, Laburnum vulgare. See WATCH AND CHAIN. 
Goudy. Mrs. Day, of North Petherton, gives me this as a name for the Meadow Buttercup, Ranunculus acris.

Goluswogs. Common Red Poppy, Papaver Rhoeas (Hatch Beauchamp and Camerton).

Golliwogs' Heads. The seed case of the Poppy, see above (Paulton).

Good Friday Flower. (1) The Moschatel, Adoxa Moschatellina, because it flowers at Easter. For many years I never heard this plant called by any other name (Castle Cary).

(2) The Schoolmistress at Barrington tells me that the Passion Flower, Passiflora carulea, is so called in that neighbourhood.

Good Friday PLANT. A correspondent at Ilton gives me this as a local name for the Lungwort, Pulmonaria officinalis.

GOoD KING HENRY. (1) Mercury Goosefoot, Chenopodium Bonus-Henricus. Col. J. S. F. Mackenzie says "It is a good example of the pitfalls in finding out how plants have come by their names. Its second botanical name is BonusHenricus. The 'Bonus' (good) was given to distinguish it from a poisonous ('Malus ') Henricus plant. Linnaeus (vidently took the plant-name from the Germans, who called it Heinrich, and Latinized it into Henricus. This, when translated into English, became Henry, as if it were a Christian name. Grimm says 'Heinrich' is not a Christian name. It is a German word for what we in English call goblin. To make confusion worse confounded, someone has put in a 'King,' and the Good Goblin becomes Good King Henry."

(2) A number of correspondents at South Petherton give me this as a local name for the leaves of the Dock, $R$ umex obtusifoli $s$.

GooD LUCK. A correspondent at Wells gives me this as a local name for the Wood Sorrel, Oxalis Acetosella.

Good NeIGHBOURHood. (1) Mercury Goosefoot or Good King Henry, Chenopodium Bonus Henricus (Devizes).

(2) Red Spur Valerian, Kentranthus ruber (Devizes).

GOOD Nerghbours. A name commonly used in West Somerset for the Red Spur Valerian, Kentranthus ruber. Mr. Edward Vivian tells me it is also used in the Trowbridge district.

Good Night at Noon. Common Mallow, Malva sylvestris.

GoODY's EYE. See CleAR EYE (2).

Gookoo Buttons. Mr. W. S. Price (Wellington) gives me this as a local name for the burs of the Common Burdock, Arctium misus. See CUсKоо ButTons. 
Gookoo Flower. See Cuckoo Flower.

Goose AND GANDER. (1) Common Veteh, Vicia cracca (Wells).

(2) Mr. W. C. Baker, late of Maunsel, gives me this as a local name for the Red Campion, Lychnis dioica. Mr. W. D. Miller points out that the name dioica implies that the stamens and pistils are borne on different flowers, and generally (as in this case) on different plants, and this method of guarding against self-fertilisation on the part of the Campion may perhaps account for this local name.

Goose AND GosLIngs. (1) A correspondent at Rodden (near Frome) gives me this as a local name for several species of Orchis, particularly O. morio. It is also applied to the Early Purple Orchis, O. mascula. See GANDER GAUzE and Gandergosses.

(2) Mr. T. W. Cowan, F.L.S., tells me that in other places the name is applied to catkins of the Willow, especially of Salix caprea.

Gooseberry Pie. (1) Great Hairy Willowherb, Epilobium hirsutum; more often called APPLE PIE.

(2) Rest Harrow, Ononis (Wells).

(3) A correspondent at Bridgwater gives me this as a local name for the White Campion, Lychnis alba.

Gooseberry Pudding. Several correspondents at Donhead (Wilts) give this as a local name for one or other of the speries of Mallow, Malva.

Goose Brus. (1) A common name for Galium Aparine; more often called GoosEGRASS, which see.

( ). A correspondent at Broadwindsor gives it a local name for the Herb Robert, Geranium Robertianum.

Goose CHICKEN. A correspondent at Sidbury (Devon) gives me this as a local name for the catkins of Willow or Sallow. See GosuIngș (1).

Goose-FLops. (1) The Daffodil, Narcissus Pseudo-Narcissus; a very common name in West Somerset.

(2) Britten and Holland in their Dictionary of English Plant Names give this as a name of the Foxglove, Digitalis purpurea, in Devonshire.

Goose-GANDER. Same as Goosex-GANDEF.

Goose-GoG. A very general name for a Gooseberry ; in Wilts a green Gooseberry.

Goose-Grass. (1) A very general name for the Bedstraw, commonly called CLeAvers, Galium Aparine, from the fact of its being used as a food for young geese.

(2) A number of correspondents give it as a name for the Silverweed, Potentilla Inserina. See GANDER-GRASS. 
(3) Several correspondents at Nettlecombe give it as a local name for the Snakeweed, or Bistort, Polygonum Bistorta, of which Anne Pratt says the seeds are peculiarly nutritive to poultry.

(4) A coirespondent at Donhead (Wilts) gives it as a local name for the Common Tansy, Tanacetum vulgare.

(5) A dwarf Sedge, Carex hirta (F. T. Elworthy). Miss Ida Roper, F.L.S., points out that $C$. hirta grows from one to two feet high, but that $C$. humilis is a dwarf sedge.

Goose Share. Same as Goose-Grass (1). Mr. T. W. Cowan, F.L.S., writes me "GooseSHARE or GOOSE-SHARETH is a corruption of its old name, Goose-heiriffe, A. Sax., gos-hegerife = goose hedge-reeve, i.e., the reeve that guards the hedge and prevents geese passing through (Turner's Herball Grateron).

Goose Tongue. (1) Same as Goose-Grass (1).

(2) Several young people at Dunster give me this as a local name for the Yarrow, Achillea Millefolium.

Goose-Weed. Same as Gander-Grass.

GoosEwoRT. A correspondent at Stockland (Devon) gives me this as a local name for the Silverweed, Potentilla Anserina. See GanderGrass.

Goosey GaNder. (1) A very common name throughout the district for the Early Purple Orchis, Orchis mascula.

(2) Several correspondents in Dorset and Devon gire it as a local name for the W ild Hyacinth or Bluebell, Scilla non-scripta. A name given to one of these plauts is frequently applied also to the other. Compare BLOOdy Bones, Granfer GriggLes, and WIDD HYACINTH.

Goosey-Goosey GANDER. A variation of the last name (1) sent me by correspondents at Wells and Long Sutton.

Gosrings. (1) The large yellow catkins of the Sallow, Salix caprea (Warminster).

(2) Early Purple Orchis, Orchis mascula (N.W. Wilts).

Goss. In most districts Gorse or Go:s is the Furze, Ulex europ cus but in N.W. Wilts this name is given to the Rest Harrow, Ononis repens. The compilers of the Wiltshire Glossary add that in this district "Gorse," Ulex, is always "Fuzz."

Gossips. Early Purple Orchis, Orchis mascula.

Go to BED AT Noon. Yellow Goatsbeard, Tragopogon pratense, from the fact of its flowers closing at mid-day. More generally called JoHN (or JACK) GO TO BED AT NOON.

Go to Sleep at Noon. Mr. W. C. Baker, late of Maunsel, gives me this as a local name for the Meadow Saffron, Colchicum autumnale. 
Gowerns. It would be interesting to know the extent to which this name (evidently a corluption of Gowan) or anything like it is used in Somerset for the Daisy, Bellis perennis. I have the name only from a school-girl at Long Sutton, who has evidently heard it used in that district, but I imagine it is not frequently used, as a number of other correspondents in the same village do not give it.

GraB. A wild or crab Apple; a Seedling Apple-tree, Pyrus malus.

Grace of GOD. (1) A correspondent at East Grinstead (Wilts) gives this as a local name for the St. John's Wort, Hypericum. Mr. T. W. Cowan, F.L.S., tells me that this old name for the st. John's Wort is common in many. places, and is not confined to Wilts. He adds that the name is also given in some places to

(2) The Hart's-holn or Buck's-horn Plantain, Plantago Coronopis.

Gracy Datsies. Daffodils, Narcissus PseudoNarcissus (West Somerset and Devon).

Gracy DAY. A Devonshire form of the above.

Gramerer GregGLE. The Bluebell or Wild Hyacinth; Scilla non-scripta (G.P. R. Pulman).

Granfer (or Graniphy) Griggies. (1) A ver'y common name, particularly in Dorset, for the Early Purple Orchis, Orchis mascula.

(2) Applied, less generally, in the same districts, to the Wild Hyacinth or Bluebell, Scilla non-scripta.

Granfer (or Grantrhy) GrigGLE-STICKS. Early Purple Orchis, Orchis mascula (Yeovil (1) Evercreech).

(2) Wild Hyacinth or Bluebell, Scilla nonscripta (Winsham).

(3) Dr. Downes tells me that in the Ilminster district this name is given to the Dandelion, Taraxacum officinale.

GRAMTER JAN. Red Campion, Lychnis dioica ('Trowbridge and Lyme Regis).

Grammer Greygle. His Honour J. S. Udal gives this as a Dorset name for the Bluebell, Scilla non-scripta, and it is also sent me by a correspondent at Chetnole.

GRAMOPHONE HoRns. (1) Honeysuckle or Woodbine, Lonicera Periclymenum (Evercreech).

(2) Salpiglossis (Muchelney).

GRAMOPHONES. above (1).

(1) Honeysuckle ; see

(2) Nasturtium, Tropaeolum maj s (Ilminster).

(3) A correspondent at Timberscombe tells me the name is there given to the Convolvulus, which may mean the Hedge Bindweed, Calystegia sepium, of the Field Bindweed, Convolvulus: arvensis, or both. 
GrAMPHA-GRIDDLE - GOOSEY - GANDER. Early Purple Orchis, Orchis mascula. A name from Zeals (Wilts) recorded in the "Sarum Diocesan Gazette."

Grampy Griggles. Bluebell, Scilla nonscripta (Milborne St. Andrew).

Grandfather Griggles. (1) Early Purple Orchis, Orchis mascula (Yeovil, Horton, and Hawkchurch).

(2) Bluebell, Scilla non-scripta (South Petherton).

(3) A correspondent at Combe St. Nicholas gives it as a local name for the Spotted Orchis, Orchis maculata.

GrandFather's BEARD. (1) Clematis or Traveller's Joy, Clematis Vitalba, more often called OLD MAN's BEARD.

(2) Correspondents at Hawkchurch (Devon) give it as a local name for a species of Horsetail, Equisetum (probably arvense).

(3) The gall or bedeguar on the Wild Rose, more often called RoBIN's PINcushron (Draycott).

(4) Dr. Watson writes "This and other similar names, as OLD MAN's BEARD, are often applied to a Lichen, Usnea, which hangs from the tree."

Grandfather's ButTons. Marsh Marigold, Caltha palustris (district from Otterhampton to Nettlecombe).

GraNDFATHER's CLOCK. A correspondent at Dorchester gives this as a local name for the Thistle.

GRANDFATHER's WEATHER-GLASS. Scarlet Pimpernel, Anagallis arvensis (Axminster district).

GRANDFATHER's WHISKERS. A variation of Grandfather's Beard (1) sent me from Yetminster.

Grandma's Datstess. Red Double Daisies, Bellis perennis (Horton).

Grandma's Nightcap. (1) The Columbine, Aquilegia vulgaris.

(2) Hedge Bindweed, Calystegia sepium (Stockland, Devon).

(3) A correspondent at North Cadbury gives this as a local name for the White Campion, Lychnis alba.

Grandmother's Bonnet. A name far less frequently used than GRANNY's BONNET for

(1) The Columbine, Aquilegia vulgaris.

(2) The Monk's-hood, Aconitum Napellus.

GRANDMother's NIGHT-CAP. The Columbine, Aquilegia vulgaris, nore generally called GRANNY's NIGHT-CAP. 
Grandiother's SPECTACLES. I wonder this appropriate name is not more generally given to the Honesty or Money in both peckets, Lunaria biennis. I have it from several young people at East Mark, but from nowhere else.

Grandrother's ToE-NALS. Correspondents at Uplyme give me this as a local name for "Fingers and Thumbs," by which I presume is meant the Bird's-foot Trefoil, Lotus corniculatus.

Granfer Giggles. The Rev. Jas. Coleman, rector of Allerton, gave this form in Notes and Queries November, 1877, as a S merset name for the Orchis (? Orchis mascula). See also under GraJIFER.

Granfer GrigG. (1) A correspondent at Bruton gives me this as a local name for the Bluebell, Scilla non-scripta.

(2) A correspondert at Tisbury gives it as a local name for the Early Purple Orchis, Orchis mascula. See also under GRAJrFER.

Granfer (or Granfy) Griggles (or GreyGLES).

(1) MIost frequently the Early Purple Orchis, Orchis mascula, especially in Dorset; but very often the

(2) Bluebell, Scilla non-scripta.

(3) The Red Campion, Lychnis dioica (Dorset). NIr. F. R. Summerhayes, of Milborne Port, gives Granfer Griggles as a local name for the Early Purple Orchis (as in 1) and GranNy Griggles for the Bluebell. A correspondent at Chilms rk (Wilis) tells me in that district the name Granfer Griggles is given to the Early Purple Orchis (as in 1) and GRANMER GRIGGLES to the Bluebsll. Mr. J. C. Mansell-Pleydell says that in Dorset Nos. 2 and 3 are sometimes distinguished by being called BLUE and RED GRANFER GREYGLES respectively.

Granfer Griggre-sticks. Early Purple Orchis, Orchis mascula (Yeovil and some parts of Dorset). See also under GRAMIFER.

Granfer Grizzle. Mr. H. A. Bending, of Shoscombe, gives me this as a local name for the Lady's-fingers or Kidney Vetch, Anthyllis Vulneraria.

Granfer JAx. 'The Red Campion, Lychnis: dioica (Odcombe). See also under Grasifer.

GRANFY'S BEARD. A number of young people. at Long Sutton give me this as a local name for the Clematis or 'Traveller's Joy, Clematis Vitalba.

Grander Griggles. The Bluebell, Scilla. non-scripta (Chilmark, Wilts). See note under GRANEER GRIGGLES.

Granny Bonnets. See Granny's Bonnets

Granny Griggles. The Bluebell, Scilla non- 
scripta (Milborne Port and Child Okeford). See note under GranFer Griggles.

Granty Jump OUt of Bed. Monk's-hood, Aconitum Napellus (Deverill, Wilts).

Granny's (or Granny) Bonnets. (1) A very general name for the Columbine, Aquilegin. vulgaris. Applied far less frequently to

(2) Monk's-hood, Aconitum Napellus.

(3) Quite a number of young people at Paulton and one at Evercreech give it as a local name for the Meadow Crane's-bill, Geranium pratense.

(4) The Foxglove, Digitalis purpurea (Sexey's School).

(5) The School-mistress at Pawlett gives me this as a local name for the Snapdragon, Antirrhinum majus.

(6) A correspondent at Winsham gives it as a local name for the Dead Nettle, Lamium.

(7) A correspondent at Rampisham (Dorset) gives it as a local name for the Water Avens, Geum rivale.

(8) Miss Whittaker, of Ruishton, tells me that this name is also given to the Winter Cherry, Physalis Alkekengi.

(9) Correspondents in Wilts and Dorset give it as a local name for the Larkspur, Delphinium Ajacis.

Granny's Cap. (1) The Columbine, Aquilegia vulgaris (Iwerne Minster, Dorset). Wilts).

(2) The Water Avens, Geum rivale (N.W.

Granry's EYe-GLAsses. A correspondent at Bruton gives me this as a local name for the Anemone (? Anemone nemorosa).

Granny's Faces. Pansies, Viola tricolor (Fuiley).

Granny's GLoves. 'The Foxglove, Digitalis purp rea (Dunke:ton).

Granny's Negdies. The Herb Robert, Gieranium Robertianım (Castle Cary).

Granny's Night-bonnet. An Everereech school-boy gives me this as a local name for the Hedge Bindweed, Calystegia sepium.

Granyy's Nightcap. (1) A very popular name throughout the district for the Columbine, Aq ilegia v.lgaris.

(2) Applied less frequently, but still very commonly, to the Monk's-hood, Aconitum Napell"is.

(3) A number of correspondents in Dorset only give this as a local name for the Lesser Stitchwort, Stellaria graminea.

(4) The Wood Anemone, Anemone nemorosa.

(5) The Hedge Bindweed, Calystegia sepium.

(6) The Field Bindweed, Convolvul $s$ arvensis (N.W. Wilts). 
(7) Several correspondents in the Axminster district give it as a local name for the "Deadly Nightshade," by which they probably mean the Woody Nightshade, Solanum Dulcamara - this confusion of the two plants being very common.

Other correspondents apply the name to the following plants in the districts shown, but I gather it is far less generally given to these plants than to the seven set out above :-

(8) B ragè, Borago officinalis (Furley).

(9) Siapdragon, Antirrhinum majus (Wambrook).

(10) Herb Robert, Geranium Robertianum (Axminster).

(11) Larkspur, Delphinium Ajacis (Gittisham).

(12) Day-lily, Hemerocallis (East Lulworth).

(13) White Campanula (Mr. W. C. Baker).

Granny's Shozs. The Monk's-hood, Aconitum Napellus (Puddletown, Dorset).

GraNiny's SLIPPER. The Monk's-hood, as above (Symondsbury, Dorset).

Granny's Tears. A correspondent at Crewkerne gives me this as a local name for the Harebell, Campanula rotundifolia.

Granny's Thmibles. The Columbine, Aquilegia vulgaris (Mr. W. C. Baker, late of Maunsel).

Granny's Tok-NaILs. Same as GrandMOTHER'S TOE-NALLS (Axminster district).

Granny Thread the Needle. (1) A Yeovil lady gives me this as a local name for the IVood Anemone, Anemone nemorosa, but I have never heard it so used myself. I have heard the name given to

(2) The Herb Robert, Geranium Robertianum, as sent me by a correspondent at Stalbridge.

Grapes. The Schoolmaster at Batcombe gives me this as a local name for the Biting Stome-erop, Sedum acre.

GRA S FLOWER. (1) I have this name only from two school-girls at Wincanton, who tell me it is given in that neighbourhood to the ChickweedI presume Stellaria graminea, as suggested by the specific name.

(2) Dr. Watson tells $m$ that he has never heard this name used in the West of England, but has occasionally heard it used elsewhere for the Crimson Vetch ing, Lathyrus Nissolia; sometimes called the Grass VETCH.

Grass Poluy (or PoLY). (1) An old name for the Purple Loosestrife, Lythrim Salicaria, given me by correspondents at Crewkerne and Rodney Stoke.

(2) Mr. T. W. Cowan, F.L.S., tells me it is also applied to the Hyssop-leaved Loosestrife, Lythrumi Hyssopifolia. 
Grass W AVES. A school-girl at Paulton gives me this as a local name for the Dog's Mercury, Mercurialis perennis, but ten other young people in the same school give it as GrEen WAVES.

Grassy Daisies. Mr. W. S. Price (Wellington) gives me this as a local name for the common Daffodil. See Gracy Daisies.

Grazies. A Yeovil school-boy gives me this as a local name for the Marsh Marigold, Calth a palustris. See Crazies.

Greater Cerandine. This is the usua English name of Chelidonium majus, of the Poppy family, and would not appear in this list but for the tact that a number of young people at Mells tell me that the name is there given to the Marsh Marigcld, Caltha pavustris.

Great Morel (or Morelde). Several correspondents give me this as a local name for the Deadly Nightshade, Atropa Belladonna. It is a fairly well-known name, and is given on account of the dark purple beiries.

Great Thunderbolt. An Evershot schoolboy gives me this as a local name for the Great Water Plantain, Alisma Plantago-aquatica.

Greens. The comprehensive name for any kind of Kale or Turnip tops, but never applied to Cabbage or Cauliflower.

GREen Besom. Broom, Cytisus scoparius (WVest Somerset). See Besom.

Green Eres. Miss Ella Ford, of Melplash (Dorset), gives me this as a local name for the Annual Knawel, Scleranthus annu s, a small plant bearing green flowers found in cornfields, but noticed by few except the botanist.

GREEN GRower. An Axminster correspondent gives me this as a local name for the Wood Spurge, Euphorbia amygdaloides.

GREEN LILY. Green Hellebore, Helleborus viridis (N.W. Wilts).

Green Sauce. (1) The Common Sorrel or Sour-dcck, R /mex Acetosa (Devon). Mir. T. W. Cowan, F.L.S., e e.ls $m$ that in the North "Green Sauce" means Sour-dock or Sorrel mixed with vinegar and sugar.

(2) The Wood Sorrel, Oxalis Acetosella (Taunton and Devon).

Green WAVES. Dog's Mercury, Mercurialis perennis (Paulton). See Grass Waves.

GreEN-Wood. A correspondent at Furley gives me this as a lceal name for the Broom, Cystisus scoparius. Dr. Watson writes "Greenweed is the name of a Broom-like herb. I suggest there has here been a corruption of Green-weed to Green-wood (this has occurred) and then an extension." 
GREY-BEARD. Wild Clematis or Traveller's Joy, Clematis Vitalba, in seed (N.W. Wilts).

Greygle, or Greyg )Le. The Bluebell, Scilla non-scripta (Wilts and Dorset).

GREx MILLET. A number of correspondents in various parts of the district send me this name for the Common Gromwell, Lithospermitm officinale.

GribBLe. (1) A Wild Apple-tree, or one raised from seed. The fruit of the Wild or Seedling Apple-tree, Pyrus Malus.

(2) Mr. W. S. Price tells me this is also the name of a cultivated variety of apple-a sweet, soft fruit, with a slightly bitter flavour.

( ) A young Blackthorn, or a Knobby Walking-stick made of it (Dcrset).

(4) Mr. T. W. Cowan, F.L.S., tells me that a former gardener of his (a Devonshire man) altways called a shoot from a tree or a short cutting from one a "Gribble."

Griggles. (1) The Bluebell, Scilla nonscripta (East Somerset and Dorset). See GREYGLE.

(2) The Early Purple Orchis, Orchis mascula, or Spotted Orchis, O. maculata (East Somerset and Dorset).

(3) SmajI Worthless Apples, remaining on the tree after the crop has been gathered in (N.W. Wilts). In some cider counties the boys who collect these apples after the principal ones are gathered call it GrIGGiING.

GRII THE COLLIER. The Orange Hawkweed, Hieracium aurantiacum. Dr. Prior says from the name of a humorous comedy popular in Queen Elizabeth's reign, "Grimm the Collier of Croydon"; given to the plant from its black smutty involucre.

Grindstone Apple. The Crab Apple; used to sharpen reap-hooks, its acid biting into the steel (Wilts).

Grinsex. Groundsel, Senecio vulgaris (Trowbridge).

GRound AsH. (1) An Ash Stick growing from the ground, and much tougher than a branch of the tree.

(2) Mr. T. W. Cowan, F.L.S., gives me this as a local name for the Common Goutweed, AEgopodiilm Podagraria, and tells me that he had a gardener (a Devor.shire man) who always called it Potash.

Ground Furze. MIrs. Day, of North Petherton, gives me this as a name for the Rest Harrow, Ononis repens.

Ground Ivy. This is the general English name for Nepeta hederacea, and would not appear in this 1 st but for the fact that Miss Shute, late 
of Oare, gives it to me as a local name for the Field Bindweed, Convolvulus arvensis.

Ground Nut. Common Earth Nut, Conopodium majus.

Ground PINE. A general English name for the Yellow Bugle, Ajuga Chamapitys, sent me by a number of correspondents. Dr. Prior says this plant was the Forget-me-not of all the authors up to the beginning of the last certury.

Ground-swell or Ground-WILL. Mr. 'T. W. Cowan, F.L.S., gives me this as an old name for the Groundsel, Senecio vulgaris, and tells me that his gardener from Devon always called the plant GRoUND-SWELL. See note under GRUNDY SWALLOW.

Groves. Duckweed, Lemna (Rev. W. P. Williams).

Grozex or Grozens. This name for the Duckweed, Lemma, is given both by Jennings and the Rev. W. P. Williams. It was sent me a few months ago by the Schoolmistress at Pawlett as a name still used in that neighbourhood.

Gruasels. Rev. Hilderic Friend gives this as a Devonshire name for the Dandelion, Taraxacum officinale.

Grundy Swallow. A Taunton lady gives me this as a local name for the Groundsel, Senecio vulgaris. MIr. 'T. IV. Cowan, F.L.S., writes me "Groundsel assimilated to groundsil = the threshold of a door (Bailey) was originally ground-suallow. A. Sax. grund-suelge, from swelgan $=$ to swallow or devour. Dr. Prior says it is still called in Scotch and Prov. Eng. grundyswallow. An old form of the word is groundsuell, as if that wherewith the earth teems. "This groundsuell is an hearbe much like in shape vnto Germander.' P. Holland, Plinie's Nat. Hist. (1634), vol. ii., p. 238."

Guirus. A lady at Compton (between Yeovil and Sherborne) gives me this as a local name for the Corn Marigold, Chrysanthemum seget:in.

GuILT or Guilty-Cup. See GH-Cup.

GUINEA-HEN FLOWER. A correspondent at Dunster gives me this as local name for the Snake's-head, Fritillaria Meleagris, but I believe the plant is very rare in Somerset, and is not. found wild anywhere in the Dunster district.

Gulty-Cups. A Devonshire name given to several species of Buttercups. Rev. Hilderic Friend particularly names Ranuncilus acris, and G. P. R. Pulman R. b:lbosis.

Guns. A correspondent at Donyat gives me this as a local name for the Shepherd's Purse 
Capsella Bursa-pastoris - no doubt owing to the explosive dispersal of the seeds. The name is sometimes given to other plants with explosive fruits.

Gussips. Mr. F. W. Mathews, of Bradford-onTone, gives me this as a local name for the Early Purple Orchis, Orchis mascula. See Gossips.

GUZzLE-BERRY. Gooseberry (Wilts).

HaAvs. Fruit of the Hawthorn (Pulman).

HAB-NABS. Fruit of the Hawthorn (Stokeunder-Ham). A corruption of HALF-AND-HALF-, which see.

HACKYMore. Knapweed, Centaurea nigra or C. Scabiosa (North Cadbury).

HAG-Rope. Wild clematis, Clematis Vitalba. whose tangled growth is much like cordage (West Somerset). Hag is probably a survival of the A.S. heg, haga, hedge. Dutch haag.

HAG-THORN. Hawthorn, Cratoeg is non gyna (West Somerset and Devon). Mr. Elworthy says : "In this, there can be no doubt, we have the older form haga, than the haw of Lit. Eng."

Hans or Hales. Fruit of the Hawthorn East Somerset and Dorset).

HAIR-BELL. See HARE-BELL.

HAIR-BRush. The Teasel, Dipsacus sylvestris,

HAIRY HEAD. A correspondent at Stalbridge gives me this as a local name for the Knapweed" Centaurea nigra.

HaIvs. Haws. Berries of the Hawthorn (West Somerset). Mr. Elworthy quotes, the popular belief : "We be gwain to have a hard winter, the haivs be so plenty."

HALF-AND-HALF. The fruit of t e Hawthornr Cratag s lic $n$ gyna (Stoke-under-Ham).

Hale-pennies and Pennies. This is sent me from the neighbourhood of Honiton as a lccal name for the Wall Pennywort, $C$ ctyledon $U m$ bilic $s$-Veneris.

HalleluJah. Wood Sorrel, Oxalis Acetosella. See Allelulia.

HALSE. Hazel, Corylus Avellana. Mr. Elworthy says: "A hazel rod is always a halsen stick." It is from this that the village of Halse takes its name.

Halves. Haws; fruit of the Hawthorn.

HANDs IN Pockets. Several correspondentt in Mid and East Somerset, particularly aSexey's School and Muchelney, give me this as a Ic cal name for the Virginia Creeper, Ampels opsis quinqi efolia. Dr. R. C. Knight gives me the interesting explanation "the petioles of 
large leaves of Ampelopsis quinquefo ia are so called because in autumn they are used by children to whip the knuckles of others with the admonition 'Hands-in-pockets.' "

HANG-Downs. Mrs. H. Day tells me that Crab Apples are known by this name at North Petheiton.

HANGING Geranidar. Saxifraga sarmentosa, from the way in which it is usually suspended in a cottage window; also known as the Strawberry Geranium, from its strawberry-like runners (Wilts). See AARON's BEARD (2).

HARCHERS. A correspondent at Ibberton (Dorset) gives me this as a local name for the Wallflower, Cheiranthus Cheiri.

HARD HACK. (1) Mr. Edward Vivian and othe correspondents in the Trowbridge district give me this as a local name for the Greater Knapweed, Centaurea Scabiosa, and the Black Knapweed, C. nigra.

(2) Mr. T. W. Cowan, F.L.S., tells me that the name is also given to the Tomentose Spiras. Spirce tomentosa, an American plant grown in many gardens.

HARD HEADS. (1) A very general name throughout the district for the Knapweeds mentioned in the foregoing paragraph.

(2) The flower-heads of the Ribwort Plantain, Plantago lanceolata, used as "soldiers" or "fighting cocks " by children everywhere (Devon).

(3) Several young people at Chew Magna give me this as a local name for the Darnel, Lolium perenne.

HARD Irons. (1) A correspondent at Leigh (Dorset) gives me this as a lccal name for a species of Centaurea, which, from her description, I believe to be $C$. Scabiosa. Both this species and $C$. nigra are frequently known as HARD HEADs or IRONWEED, and the above name appears to be a local combination of the two.

(2) Mr. T. W. Cuwan, F.L.S., tells me that in the north this name is given to the Corn Crowfoot, Ranunculus arvensis.

HARE BELL. This is the general English name for Campanula rotundifolia, and would not be included in this list but for the fact that correspondents in somerset, Dorset, and Devon give it as a lccal name for the Wild Hyacinth or Bluebell, Scilla non-scripta.

HARE'S BEARD. An old country name for the Great Mullein, Verbascum Thapsus, which I gather from correspondents is still used in the Wimborne and Shute (Devon) districts. The plant was also formerly called BEAR's BEARD. Dr Prior says it is perhaps a mistaken translation of the Italian name tasso barbasso, as if 
bearded badger, which is itselı a manifest corruption of the Latin Thapsus Verbascum.

HARE's EAR. (1) The general English name for Bupleurum rotundifolium, of ten called Thorowwax.

(2) The Hedge MIusiard or Treacle Mustard, - Erysimum oriental:

HaRE's Foot Clover. Hare's foot Tiefoil is the general English name for Trifolium arvense, so called from its soft downy heads of flowers; but both MIr. F. T. Elworthy and Rev. R. P. Mrurray give this as a West Somerset name.

HARE'S LeTTUCE. A correspondent at Axminster gives me this as a local name for the Sow-Thistle, Sonchus oleracevs. Anne Pratt says "The timid wild hare will creep through garden hedge before its owner has waked up to the dawn, and will there take a breakfast on the SowThistle."

Hare's Meat. Wood Sorrel, Oxalis Acetosella (Wells).

HARE's Palace. The Sow-Thistle, Sonchus olerace's. See HARE'S LETTUCE.

HARE's PARSLeY. A school-girl at Draycott gives me this as a local name for the Hemlock, Conium maculatum.

HARE's TAIL. The Hare's Tail Cotton-grass, Eriophorum vaginatum.

HARRY DoBs. Several young people at Thorne St. Margaret give me this as a local name for the Pink, Dianthus Caryophyllus.

HARRY NeTtus. A correspondent at Leigh (Dorset) gives me this as a local name for the Betony, Stachys Betonica. Probably a corruption of " Hairy Nettle," from the hairy or downy leaves.

HART BERRY. The Whortle-berry, Vaccinium Myrtillus (East Somerset and Dorset). See ARTS.

HART's Horn. A correspondent at Stoke StGregory gives me this as a local name for "Herb Ivy," which is an old name for the Yellow Bugle (see Ground PINe) and also for the Buck's-horn Plantain, Piantago Coronopus.

HART's SkULI. A correspondent at Chideock (Dorset) gives me this as a local name for "Blue Buttons," which may (or may not) be any one of the plants I have named under that heading.

HART's TONGue. The Common Smooth-leaved Fern, Phyllites Scolopendrium. In West Somerset more generally called LAMB TONGUE.

HARVEST DAISY. A correspondent at Symondsbury (Dorset) gives me this as a local name for the Ox-eye, Chrysanthemum Leucanthemum. 
HARVEST Flower. A correspondent at Chard gives me this as a local name for the Corn Marigold, Chrysanthemum segetum.

HasketTs. His Honour J. S. Udal gives this as a Dorset name for Hazel and Maple bushes.

Hasty RogæR. Miss Ida Roper, F.L.S., gives. me this as a Devonshire name for the Nipplewort; see below.

Hasty Sargeant. The Nipplewort, Lapsana communis (East Somerset and North Dorset).

HAves. Haws. 'The fruit of the Hawthorn (Dorset).

HAw. A very general name for the fruit of the Hawthorn, Cratagus monogyna. This name arose from the supposition, Prior says, that Hauthorn was the plant which bears haws, whereas its name really implies the thorn which grows in the haw, hay, or hedge. A. Sax haga, hege.

Hax-MAIDs (or MAIDENS). Ground Ivy, Nepeta hederacea. "Hay" means hedge, and the "haymaidens" are the plants which grow in the hedges. Used for making a medicinal liquor, known as "Hay-maiden tea."

HAYRIFF. (1) An old name for the Goosegrass or Cleavers; Galium Aparine. Mr. T. W. Cowan, F.L.S., tells me that in Glos. this plant is called HAIREVE, and in the north HAIRUP, HATRough, or HAY-RJUGH, which are corrupt forms of harif. O.Eng. hayryf, A Sax hegerife, = hedge-reaver or robber from its habit of laying hold of anything that touches it. Gerard says it was called" of som Philanthropos, as though he should say, a man's friend, bicause it taketh hold of mens garments." Herbal p. 964.

(2) Rev. Hilderic Friend says that although in all his works of reference this name is given to the Goose-grass, when he has held up the Meadow-sweet, Spiroea Ulmaria, and asked its name, he has sometimes been told it is HAYRIFF.

(3) Dr. Prior says the name was originally given to the Burdock, Arctium minus, but in his day to the Goose-grass. It comes from the A.S. hege = hedge, and reafa, which means both a taxgatherer and a robber, and was given to the Burdock on account of its habit of plucking wool from passing sheep.

(4) A correspondent informs me that in Dorset the name is given to the Black Bindweed, Polygonum Convolvulus.

HAY-SHACKLE. Yellow Rattle, Rhinanthus Crista-galli.

Headache or Headache Flower. (1) The Field Poppy, Papaver Rhoras; from the effect of its odour. The poet Clare wrote

Corn poppies that in crimson dwell, Called "Headaches" from their sickly smell. 
(2) The Herb Robert, Geranium Robertianum (Stoke-under-Ham and Closworth).

Heads and TaILs. This is sent me from the Honiton district as a local name for the Plantain.

HEARE-NUT. This is given as a Dorset name for the common Earth-nut, Conopodium majus, by His Honor J. S. Udal, who says hares are fond of its green leaves.

HeART OF OAK. The inner solid portion of the trunk of an oak tree (Mr. W. S. Price).

Heart of THE Earth. A correspondent at Stalbridge gives me this as a local name for the Self-heal, Prunella vulgaris.

Heart-Pansy. Rev. Hilderic Friend says "The shape of the Pansy leads the Devonshire folk frequently to call it Heart-Pansy, as well as Heart's-ease, or, as 1 have heard it pronounced, Heart-seed." Mr. T. W. Cowan, F.L.S., tells me that the corruption "Heart-seed" is used in Buckinghamshire as a name for the Pansy, Viola tricolor.

Hearts. Whortleberies, Vaccinium Myrtillus (East Somerset and Dorset).

HEART's EASE. A very general name for the Pansy, particularly the small wild Pansy, Viola arvensis. The name was given to the plant because the old herbalists thought it a good cordial.

Hearts on Strings. Dicentra spectabilis, known also as Bleeding Heart, Locks and Keys, Lady's Locket, Lyre Flower, and by many other names.

Heath. Mr. Elworthy says : "The only name for Calluna and Erica of all varities. In this (Wellington) district (the word) HEATHER is unknown. We have the well-known Long-heath and Smail-heath as described by Britten ex Lyte."

HeATH-URTS (or HeATH-HURT:. Dr. Watson tells me that this name was given to him by a moman at Horner to whom he showed a piece of Crowbeiry, Empetrum nigrum, he had picked near Dunkery. She added that in her young days children ivere told not to pick the berries as they were poison.

HeATHer. Common Ling, Calluna vulgaris.

HEATHER-BELL. The Harebell, Campanula rotundifolia (Kimmeridge, Dorset).

Heath-Urts. Dr. Watson tells me that a woman at Horner, near Dunkery, gave him this as the name of the Crowberry, Empetrum nigrum, and said she had always been told to leave them alone as they were poison, which is not the case. Dr. Watson says he has eaten lots of them, and that they form good food for grouse on the 
Pennines. I believe in some parts of England they are called HeALTH-BERRIES.

Heather Fue. A correspondent at East Harptree gives me this as a local name for the Cotton-grass, Eriophorum.

Hedge BeLL. The greater Convolvulus or Bindweed, Calystegia sepium.

HEDGE-HOGS. (1) Correspondents at Odcombe and Lyme Regis give me this as a local name for the Shepherd's Needle, Scandix PectenVeneris.

(2) Goose-grass, Galium Aparine (Ilton).

(3) The seeds of the Burdock, Arctium minus (Curry Mallet).

(4) The prickly seed-vessel of the Corn Buttercup, Ranunculus arvensis (N.W. Wilts).

Hedge Hyssop. (1) Common Milkwort, Polygala vulgaris.

(2) Mr. T. W. Cowan, F.L.S., tells me this name is also given to the Lesser Skullcap, Scutellaria minor.

Hedge LiLy. Same as Hedge-bell.

HEDGE Lovers. A correspondent at Stockland (Devon) gives me this as a local name for the Herb Robert, Geranium Robertianum.

Hedge Peg (or Pick). The fruit of the Sloe, Prunus spinosa (N.W. Wilts, also i. Hants).

HEDGe PopPy. Correspondents at Winsham and Axminster give me this as a local name for the Foxglove, Digitalis purpurea. See 1 OPPy.

HEDGE-SPECKS. (1) Mr. Edward Vivian (Trowbridge) gives me this as a local name for the berries of the Hawthorn, Cratoggus monogyna.

(2) In North West Wilts the name is given to the Sloe. See Hedge Peg.

HEDge TAPER or Hag TAPER. An old name for the Mullein, Verbascum Thapsus. See also HIG TAPER.

HE-GRASS. Grass before mowing (Pulman). In East Somerset the same as EE-Grass, i.e., grass after mowing.

HELLUM or HAULM. The dead stalks of peas, beans, potatoes, \&c. Not applied to straw of any kind (Mr. W. S. Price).

HELMET-FLOWER. (1) Monk's-hood, Aconitum Napellus.

(2) Dead Nettle, Lamium (Glastonbury).

(3) The genus Scutellaria.

HeLrut. His Honour J. S. Udal gives this as a Portland name for the Herb Alexander, Smyrmium Olusatrum (possibly a corruption of Heal-root).

Hen AND Chickens. A name given to a number of different plants, but most generally 
in this district to

(1) London Pride, Savifraga umbrosa.

(2) The large double Daisy, Bellis perennis, garden variety; and $B$. perennis prolifera.

(3) The Houseleek, Sempervivum tectorum.

(4) Bird's-foot Trefoil, Lotus comiculatus.

(5) The old-fashioned pot-plant, Saxifraga sarmentosa, often called Strawberry Plant or Mother of Thousands.

(6) Shepherd's Purse, Capsella Bursa-pastoris (Wells).

(7) Miss M. J. Shute, late of Oare, gives it as a local name for the Wood Sorrel, Oxalis Acetosella.

(8) Correspondents at Dunster and Widworthy give it as a local name for the Herb Robert, Geranium Robertianum.

(9) In Devon, the Narcissus.

Henbir. (1) The Henbit Deacl-nettle, Lamium amplexicaule.

(2) A correspondent at Rodney Stoke gives it as a local name for the Black Horehound, Ballota nigra.

HeN ChICKen. A correspondent at Bloxworth (Dorset) gives me this as a local name for the Biting Stonecrop, Sedum acre.

Hen Penny, or Hex Pexny Grass. The Yellow Rattle, Rhinanthus Crista-galli.

HePs. Hips; the fruit of the Dog-rose (Dorset).

Herb Bennett. (1) Common Avens, Geum urbanum. The name is said to be a corruption of Herba benedicta, i.e., the blessed herb, because, according to an ancient writer, "where the root is in the house the devil can do nothing, and flies from it ; wherefore it is blessed above all other herbs."

I am indebted to Mr. T. W. Cowan, F.L.S., for the information that in some places this name is also given to the three following plants:-

(2) Common Hemlock, Conium maculatum.

(3) All-heal, Valeriana officinalis.

(4) Seif-heal, Prunella vulgaris.

HERB CARPENTER. An old name for the Common Bugle, Ajuga reptans, sent me by several correspondents. The plant owes this name to the fact that it was formerly greatly valued as an application to cuts and wounds.

HERB ChRISTOPHER. (1) Several correspondents send me this old name for the Baneberry, Actoea spicata, but I believe the plant is not found in the counties with which I am dealing.

(2) The name is frequently given to the Royal Fern, Osmunda regalis.

HERB EVE. Another from of HERB IVY, which see. 
HERB Grass. Rue, Ruta graveolens; evidently a corruption of HERB OF GRACE, which see.

Herb IVy. (1) An old name for the Yellow Bugle, Ajuga Chamapitys, sent me by several correspondents, although I believe the plant does not occur in this district.

(2) The Buck's - horn Plantain, Plantago Coronopus. See HART's-HORN.

Herb of Grace or Herb of Repentance. Rue, Ruta graveolens. Dr. Prior says this name is from the word rice, having also the meaning of repentarce, which is needful to obtain God's grace; a trequent subject of puns in the old dramatists.

He must a void the crimes he lived in ;

His Physicke must be Rue (ev'n Rue for sinne) Of HERB OF GRACE, a cordial he must make ;

The bitter cup of true repentance take.

J. WITHER, Britain's Remembrance, 1628.

Herb Peter. The Cowslip, Primula veris; said to be from its resemblance to a bunch of keys, which is the badge of St. Peter.

HeRb Robert. (1) The usual English name of the Stinking Crane's-bill, Geranium Robertianum.

(2) Rev. H. Friend says : "In Somersetshire the name of Herb Robert is often applied 10 a member of the Sage tribe, Salvia coccinea, which bears very handsome scarlet flowers, and looks very much like a Foxglove or Gladiolus at the distance, as far as its shape and formation are concerned."

HEPBS. A term applied to any plant having a reputed medicinal value.

Herb Trinity. (1) The Pansy, Viola tricolor from having three colours combined in one flower.

(2) The same name is also given to the Anemone and to the Clover on account of their having three leaflets combined in onc leaf.

Herb True-Love. The Herb Paris, Paris quadrifolia, sometimes called Four-leaved Grass, or True-love Knot.

Herb Twopence. (1) A common name for the Moneywort, Lysimachia Nummularia, from its pairs of round leaves.

(2) A correspondent at Stockland (Devon) gives it as a local name for the Purple Loosestrife, Lythrum Salicaria.

Hethurts, i.e., Heath-worts or Whortle. Mr. W. D. Mciller gives me this as a name used in the neighbourhood of Dunkery Beacon for the Crowberry. See Heath-uRTS.

HEW-MIACK. The stock or stem of the Wild Rose, Rosa canina, used for budding or grafting upon. Mr. W. D. Miller tells me that when he has been partridge driving he has been pointed to his stand by a beater as "behind thicce gurt 
OomACK," indieating a single rank bramble stem. See EwE BRIMBLE.

HICKYmore. Knapweed, Centaurea nigra or C. Scabiosa (North Cadbury).

Hiddgy PIDDgy. A correspondent at Dalwood (Devou) gives me this as a local name for the Stinging Nettle, Urtica dioica. See HokY PokY.

Hig (or HIGH) TAPER. The Great Mullein, Verbascum Thapsus. Probably from A.S. hege or heg $\alpha=a$ hedge, and taper, its stalks when dipped in grease being formerly used for burning (Prior). See Hedat-TAPER and CANDLEWICK.

HigH TAPER. The Great Mullein, Verbascum T'hapsus.

Hinu Poppy. The Foxglove, Digilalis purpurea (Nettlecombe and Stogursey districts).

HILL-TROT (apparently a corumption of
ELTROT). (1) Cow-parsnip, Heracleum Sphondylium.

(2) Water Hemlock, Enanthe crocata (S.W. Wilts, Charlton, and Barford).

(3) Mr. T. W. Cowan, F.L.S., tells me that in the New Forest this name is given to the Wild Carrot, Daucus Carota.

Hrrp. The fruit of the Sloe, Prunus spinosa (N.W. Wilts).

HrP. The fruit of the Dog-rose, Rosa canina.

HobBly FLower. A correspondent at Mells gives me this as a local name for the Horse Chestnut, Assculus Hippocastanum. See below.

HoBвLX HoNkER. The Horse Chestnut (Frome). See above.

Hock-HOLLER. Hollyhock, Althar rosea. This is also the name of a hamlet in the parish of West Buckland, near Wellington.

HoG's BEAN. A correspondent at Bishop's Lydeard sends me this old name for the Henbane, Hyoscyamus niger. According to Amme Pratt, the seed-capsule is shaped like a bean, and pigs are said to eat the plant.

HoGwEEd. Cow-parsnip, Heracleum Sphondylium ; from the fondness of hogs for its roots.

Hoky-Poky. A correspondent at Axminster cives this as a local name for the Stinging Nettle, Urtica dioica. See HIDdgy PIDdaY.

Holland Smocks. Greater Convolvulus or Bindweed, Calystegia sepium.

HoLly ANDERs. A school girl at Long Sutton gives me this as a local name for the Holly-hock, Althcea rosea.

HoLxy-Hock. (1) This is the usual English nime for the Lose Mallow, Althaca rosea. Mr. T. W. Cowan, F.L.S., writes : "The old form of 
the word was Holy-hocke, apparently so called because it was introduced from the Holy Land. 'Holly' has nothing to do with the tree so called. 'Hock' is evidently A. Sax. hoc = the mallow, which is also called Hock-herb."

(2) A correspondent at Hawkchurch (Devon) gives me this as a local name for the Foxglove, Digitalis purpurea.

Holis. Mr. F. T. Elworthy sayz "Tae Oommon Holly is always so culed-not applied to any kind of oak." $\mathrm{R}$ v. Wm. Barnes says; "especially low and mor prickly holly, in distinction from taller and smoother leaved."

HolM OAK or Holly OAK. Mr. T. W. Cown, F.L.S., wiites "Quercus Ilex or Evergreen Oak, as if connected with holm, a water-side plant, from O. Eng. holme = the Holly, which is a corrupt form of holin, A. Sax. holen $=$ Holly. Gerard says 'Ilex is named of some in English Holme, which signifieth Holly or Huluer.'"

Holrod. His Honour J. S. Udal gives this as a name for the Cowsip, Primula veris, in the Swanage district.

Hotr Herb. Common Verviin, Verbena officinalis.

HoLx InNocents. A correspondent at Towbridge gives me this as a local name for the $\mathrm{H}_{\mathrm{w}} \mathrm{w}$ thorn, Cratogus monogyna.

Hour Pokers. This is given $\mathrm{m} \geq$ as a Devonshire name for the Great Reed-mace, Typha latifolia, more commonly known as the BULRUSH.

Holx ThorN. See Glastonbury Thorn.

HоMє-Bush. Holly. See Hour.

HoNesty. (1) Lunary, Lunaria biennis; the general name for the plant which is frequently known as MONEY-IN-BOTH-POCKETS.

(2) This name is sometimes given in N.W. Wilts to the Traveller's Joy, Clematis Vitalba.

HoNey Ball. Buddleia globosa.

HONEY BEE. A correspondent at Axminster gives me this as a local name for the White Dead Nettle, Lamium album. See BEE-NETTLE and HONEY-FLOWER (1).

HoNey-BeLL. Both Mr. and Mrs. Lansdowne (Over Stowey) give me this as a local name for the Canterbury Bell, Campanula Media.

HoNeY-BotTle. (1) The Cross-leaved Heath, Erica Tetralix. In Wiltshire the name is given to

(2) The Heather, Calluna vulgaris, and

(3) The Furze, Ulex europous.

HONEY DEW. A correspondent at Hillfarrance gives me this as a local name for the Stephanotis. 
HoNer-Flower. (1) Wnite Dead Nettle, Lamium album, South Petherton.

(2) A correspo adent at Colyton gives this as a local name for the Meadow-sweet, Spircea Ulmaria ; often called HONEY-SWEET.

(3) The general English name for the genus Melianthus.

Honey Plantain. Hoary Plantain, Plantago media (White's Bristol Flora).

Honex Stalks. Several correspondents in the Yeovil and Martock district give me this name as being used locally for the common Red. Clover, Trifolium pratense. It is used by Shakespeare, who speaks of

Words more sweet and yet more dangerous

Than baits to fish or Honeystalks to sheep.

HoNEY-SUCK. See HoNeY-SUCKIE (1) and (2).

HoNex-suCkERS. See HoNer-suckle (2).

HONEY-SUCRLE. (1) The general English name for the Woodbine, Lonicera Periclymenum.

(2) A common name in East Somerset and other parts of the district for the Red Clover, Trifolium pratense.

The flowers of both the above plants contain a good deal of honey, which is sicked out by the bees ; and the florets of the latter are often pulled out and sucked by children for the sweet taste they yield.

(3) Rev. Hilderic Friend gives it as a Devonshire name for the Hedge Bindweed, Calystegia sepium.

(4) In S.W. Wilts the name is given to the White Dead Nettle, Lamium album, the flowers of which are sucked by the children for the honey they contain.

(5) A correspondent at Stour Provost (Dorset) gives it as a local name for the Bugle, Ajuga reptans.

Honey-sweet. The Meadow Sweet, Spircea Ulmaria.

Honiton LACE. (1) A number of colrespondents in the Chard and East Devon district give me this as the local nam? for the Upright Hedge Parsley, Caucalis Anthriscus.

(2) Wild Chervil, Chrrophyllum temulum (Winsham).

(3) Common IIemlock, Conium maculatum (Winsham).

Hood (or Hoop) Petticoat. Several young people at Stockland (Devon) give me this as a ocal name for the Dafiorlil, Narcissus PseudoNarcisens.

Hook-HEAL. An old name for the Self-heal, Prunella vulgaris, which would appear to be still used in many places, judging from the number of coirespondents who have sent the name to me. 
The plant was very largely used by the old herbalists for the healing of wounds inflicted by sickles, scythes, and other sharp instrumentshence the name.

Hooks and Hatchets. Mr. H. A. Bending, of Shoscombe, gives me this as a local name for the seeds of the Maple, Acer campestre.

Hop Crover. Black Medick, Medicago lupulina. Probably due to confusing this plant with the Hop Trefoil, Trifolium procumbens. The two plants are very similar, except when in fruit, although the flowering heads of the Medick contain only about one-third the number of flowers of the Hop Trefoil.

Hор o' Mr THUмв. (1) Bird's-foot Trefoil, Lotus comiculatus (Yeovil). (IIton).

(2) Herb Robert, Geranium Robertianum

Hoptops. Mr. Edward Vivian (Trowbridge) gives me this as a very common local name for the tops of young nettles, rorm:rly gathered and boiled by country people. Dr. Watson tells me that the tops of Hops are used in the same way and make an excellent vegetable.

HornBeam. This is the general English name for Carpinus Betulus, sometimes called the Horse-beech; but in West Somerset the name is commonly given to the Wych Elm, Ulmus glabra.

Horse AND Hounds. Miss Ella Ford, of Melplash (Dorset), gives me this as a local name for the common Bugle, Ajuga reptans.

HorsE-BANE. The Fine-leaved Water Dropwort, Enanthe Phellandrium.

HoRSE-BUCKLE. A Salisbury correspondent gives me this as a Wiltshire name for the Cowslip, Primula veris.

Horse Buttercup. A common name in West Somerset and Devon for the Marsh Marigold, Caltha palustris ; so called because it is "like a buttercup, only a large pattern." The prefix "Horse" in local names of flowers is frequently used to designate a larger or coarser kind, as distinguished from smaller species or varieties which also exist.

Horse DATSy. (1) A very common name throughout the district for the Oxeye Daisy, Chrysanthemum Leucanthemum.

(2) A Taunton correspondent gives it as a local name for the Scentless Mayweed, Matricaria inodora.

(3) Most, if not all, of the Chammiles; Dr. Watson suggests chiefly to Matricaria Chamomilla and Anthemis Cotila.

Horse Dashel. Spear Plume Thistle, Cnicus lanceolatis (Devon). 
Horse HARDHEad. The Black Knapweed, Centaurea nigra.

Horse Hoof. The Coltsfoot, Tussilago Farfara

Horse KNoBs (or Knops). The Black Knapweed, Centaurea nigra (Dorset).

Horse Mint. The usual name for the Wild Mint, common in marshy places, Mentha aquatica.

Horse Mushroom. Agaricus arvensis, a larger and coarser variety than the common Mushroom, A. campestris. Mr. Worthington G. Smith says that the mushrooms cultivated by gardeners are a variety of the Horse Mushroom, and not of A. campestris, as is usually supposed.

Horse-nut Tree. Mr. W. S. Price (Wellington) gives me this as a local name for the Horse Chestnut.

Horse PARsLey. (1) A correspondent at Stoke St. Gregory gives me this as a local name for the Alexanders, Smyrnium Olusatrum. Dr. Watson suggests probably a mistake, as this is nearly always a seaside plant and is very rarely found inland.

(2) A school-girl at Oakhill gives it as a local name for the Cow-parsnip, Heracleum Sphondytium.

Horse Peppermnt. This name is sometimes given in N.W. Wilts to the Bugle, Ajuga reptans.

HorSE RADISH. (1) This is the usual English name for Cochlearia Armoracia, which is not a native plant, but is frequently found wild in ditches and elsewhere, having escaped from cultivation.

(2) MIiss Ella Ford, of MIelplash (Dorset), tells me the name is in that district given to the Wild Radish, Raphanus Raphanistrum.

(3) The roots and leaves of the Monkshood, Aconitum Napellus, have often been mistaken for Horse Radish, and a number of deaths have occurred in consequence of its having been caten.

Horse RHUBU'B. Mr. Edward Vivian (Trowbridge) gives me this as a local name for large, coarse Rhubarb.

Horses AND CHARIOTS. (1) Mr. F. R. Summerhayes, of Milborne Port, gives me this as a local name for the Quaking Grass, Briza media.

(2) A school-girl at Oakhill gives it as a local name for the Lupin, Lupinus (? albus).

HORSE'S BREATH. A country name for the Rest Harrow, Ononis repens, sometimes called STAY-PLOUGH. It has been suggested that this name is due to the harder breathing of the horses as they endeavour to plough through the plant.

Horse-SHOE. The Sycamore, Acer Pseudoplatanus (Barford St. Martin and S.W. Wilts). 
Horse-shoE Flower (or LEAF). A correspondent at Bloxworth (Dorset) gives me the former as a local name for one of the Crane's-bills, and a school-girl at Sampford Arundell gives the latter as a lecal name for a Geranium.

Horse's Mouth. A school-girl at Long Sutton gives me this as a local name for the Snapdragon, Antirrhinum majus.

Horse's TAILs. Several school-children at East Mark give me this as a local name for the common Sun Spurge, Euphorbia Helioscopia, but I fancy there must be some confusion here.

Horse Thistue. Spear Plume Thistle, Cnicus lanceolatus (West Coker). See Horse DASHEL.

Horse (or Hoss) Tongue. The Hart's Tongue Fern, Phyllitis Scolopendrium (Dorset).

Horse VIoLet. (1) A name sent me by several school-children at Long Sutton and by correspondents in several parts of Dorset for the red or pink variety of the Violet, Viola odorata.

(2) The Dog Violet, Viola canina.

(3) The Wood Violet, $V$. Riviniana and $V$. sylvestris.

(4) Rev. Hilderic Friend says: "Horse Violet is the local name in Somersetshire for the Pansy or Heart's-ease." Viola tricolor, on account of the flower being a large kind of violet.

Hoss. See Horse and its compounds.

Hot Cross Bun. A correspondent at Bloxworth (Dorset) gives this as a local name for the Spindle-tree, Euonymus europaus-probably from the shape and divisions of the berries.

Hound's TooтH. Couch Grass, Agropyron repens (Compton, near Yeovil).

HousE LEEK. This is the general English. name for Sempervivum tectorum, and would not be included in this list but for the fact that Mrs. Day, of North Petherton, gives it as a local name for the Biting Stonecrop, Sedum acre, in connection with which Mr. T. W. Cowan, F.L.S., kindly sends me the following interesting extract from Turner :-"Sedum is called in greke Aeizoon, and the fyrst kynde and moste spoke of, of writers, is called in englishe Housleke cr syngrene. The second kynde is called in English thryit or stoncroppe. The thyrd kinde is called in Englishe Mouse tayle or litle stoncroppe, and in duche Maur pfeffer. Al these kyndes growe on walles and houses."

HuD. The shell of peas or beans.

HUF CAP. A plant; or rather a weed, found in fields, and with difficulty eradicated; given by Jennings, who does not further identify it. An East Somerset correspondent applies the word to tough clumps of grass roots and leaves occurring on marshy ground. Holloway also gives Huff Cap 
as used in Somerset, Norfolk, and Suffolk to describe a blustering, swaggering fellow. Mr. T. W. Cowan ,F.L.S., tells me it is the name of a species of Pear used in making perry, and that in Herefordshire the name HUFF CAP is given to Couch-grass.

HugGy Me Close. A correspondent gives me this as a Dorset name for the Goose-grass, Galium Aparine. According to Holloway, the name is used in Somerset for a fowl's merry-thought.

Hulm. Holly, Ilex Aquifolium (Odcombe). see Hows.

HuLver. An old name for Holly. Hulfere, A.S. for Holly, occurs in Chaucer.

HuMAcks. Wild-briar stocks, on which to graff Roses (Rev. W. P. Williams). See Hewarack.

HUMBLE-BEE FLower. Bee Orchis, Ophrys apifera (Chetnole).

HUMP-BACKS. A Hatch Beauchamp name for the Violet-presumably from the way the stalk bends near the flower.

HUMPY-SCRUMPLES. Cow-parsnip, Heracleum Sphondylium (Devon).

Hundreds AND Thousands. (1) Ivy-leaved Toadflax, Linaria Cymbalaria.

(2) House-leek, Sempervivum tectorum.

(3) Virginian Steck, Malcolmia maritima.

(4) London Pride, Saxifraga umbrosa.

(5) I eruvian Heliotrope, Heliotropium peruvianum (Camerton).

(6) The seeds of the common Sorrel, Rumex 4 cetosa.

Hunters. Seeds of the common Sorrel, Rumex Acetosa (Stoke-under-Ham). ? A corruption of "Hundreds."

HURR BURR. The Burdock, Arctium minus.

HuRTLEBERRy. The Whortlebery, Vaccinium Myrtillus.

HuRTs. A contracted form of HURTLEBERRX (see above); apparently a corruption of the A.S. heorotberige, the "hartberry," from heorot or heort = a heart. T. Fuller, in his Worthies, Devonshire, says "Hurlberries, in Latine Vaccinia, most wholesome to the stomach, but of a very astringent nature; so plentiful in this Shire that it is a kind of Harvest to poor people."

HurT Srckle. The Cornflower or Blue-bottle, Centaurea Cyanus, "because," says Culpepper, "with its hard wiry stem it turneth the edge of the sickle that reapeth the corn."

HצACINTH. A weil-informed correspondent at Watchet gives me this as a local name for the Yellow Flag, Iris Pseudacorus, but it is not easy to understand. 
Hypocrites. This is sent me flom Combe St. Nicholas as a local name for Dog Violets. Compare DECEIVER.

ICE-PLANT. (1) The common name for all varieties of Hesembryanthemum,especially $M$. crystallium.

(2) Applied also to other plants with fleshy leaves, especially to such as are glossy or look as though they had hoar-frost on them, such as Houseleeks, Stonecrops, \&c. From several parts of Somerset I have had this sent me as a local name for the Stonecrop, Sedum.

(3) The Pennywort, Cotyledon UmbilicusVeneris (Avliscombe).

Indian Cress. A general English name for the Nasturtium.

INDIAN PINK. Dianthus chinensis; sometimes called French Pink and Chinese Pink.

INDIAN Poppy. MIy Watchet correspondent gives me this as a local name for the

(1) Moumtain Poppy, Meconopsis cambrica, and the

(2) Yellow Horned Poppy, Glaucium flavum.

INDIAN SHот. The general English name for the genus Canna.

INGUX. Onion (F. T. Elworthy).

ININ, Onion (Jennings).

INING (pronounced Eye-ning). Onion (WVest Pennald).

INNION. Onion.

The late G. P. R. Pulman says : "The countryman illustrates the diversity of mental and moral characteristics in this way :-

Def'ernce in taste as in opinion,

'Zum lik' a apple an' zum a innion.

InNocent. (1) Lily of the Valley, Convallaria majalis (Miss Ella Ford, Melplash).

(2) Daisy, Bellis perennis (from a school-girl at Castle Cary).

Mr. T. W. Coman, F.L.S., tells me that in Northamptonshire this term applied to flowers means small and pretty.

IroN FLowER. A school-boy at Winscombe gives me this as a local name for the Broad-leared Garlic, Allium ursinum.

Iron PeAr. White Beam, Pyrus Aria. Iron Pear Tree Farm, near Devizes, is said to take its name from this tree. (N.W. Wilts).

IroN WEED. Greater Knapweed, Centaurea Scabiosa, and Lesser (or Black) Knapweed, $C$. nigra. Iron-hard, Yronhard (Gerarde), old Eng. Isenhearde, name for Centaurea nigra, corruption of Iron-head, another popular name for the same (Prior). Gerarde gives I ronhard for Knapweed, 
i.e., Knobweed, the same plant which has "a is caiy head or $k .0 p$ beset with most sharpe prickles" (Herball).

IsRaflites. Mr. Edward Vivian, of Trowbridge, gives me this as a local name for the Virginian Stcck, Malcolmia maritima. Compare CHILDREN OF IsRage (1).

IVY BeLLs. Several young people at Bathealton give me this as a local name for the Marsh Marigold, Caltha palustris.

IVY FLOWER. The Spindle, Euonymus e uropeus (from a school-girl at Chewton Mendip).

JACK ABED AT NoON. A variation of JACKGO-TO-BED-AT-NOON (Allerford).

JACK AND JoAN. Double Polyanthus (Axminster).

JACK AND THE BeAnstalk. Common Milkwort, Polygala vulgaris (Ilton).

JACK BY THE HEDGE. (1) A very general name for the Garlic Treacle-mustard, Sisymbrium Alliaria.

(2) Miss Parkin tells me that some of the school-children at Brompton Regis give this name to the Herb Robert, Geranium Robertianum.

JACK Flower. Herb Robert, Geranium Robertianum (Tarrant Gunville).

JACK Go To BED. Yellow Goat's-beard (Thorncombe). See below.

JACK GO TO BED AT NooN. (1) A very general name for the Yellow Goat's-beard, Tragopogon pratense.

(2) The Common Star of Bethlehem, Ornithogalum umbellatum.

JACK HoRNER. Herb Robert, Geranium Robertianum (Chardstock).

JACK IN A LANTERn. Cape Gooseberry, Physalis edulis or $P$. peruviana; a tropical plant of the Nightshade fanily, bearing edible berries (Over Stowey).

JACK IN THE Box. (1) Wild Arum or Cuckoopint, Arum maculatum.

(2) A correspondent at Plush (Dorset) gives it as a local name for the Figwort, Scrophliaria.

(3) Greater StitchwoIt, Stellaria Holostea (Evershot).

(4) Double Polyanthus (Muchelney).

JACK IN THE BUTTERY. Biting Stonecrop, Sedum acre. See JACK OF THE BUTTERY.

JACK IN THE GREeN. (1) Wild Arum or Cuckoo-pint, Arum macklatum (Bradford-onTone).

(2) The Polyanthus, particularly the "hosein-hose " variety. 
(3) The Pheasant's-eye, Adonis ann!a (S.W. Wilts).

JACK IN THE HedGe. (1) Garlic Trezclemustard or Sauce-alone, Sisymbri $m$ Alliaria.

(2) The Red Campion, Lychnis dioica (Evercreech).

(3) Greater Stitchwort, Stellaria Holostea (Ilminster).

JACK IN THE Lantern. (1) The Red Campion, Lychnis dioica (South Dorsel).

(2) A correspondent at Fivehead gives me this as a local name for the "Star of Bethlehem," by which she may either mean Ornithogalum umbellatum or possibly the Gieater Stitchwort, Stellaria Holostea, which is frequently called the "Star of Bethlehem " in Somerset.

JACK IN THE PULpit. (1) A common name throughout the district for the Wild Arum or Cuckoo-pint, Arim mac:ılatim ; called also Parson (or Priest) in the Pulpit.

(2) A weil-informed correspondent st Camerton gives this a: a lceal name for the Anemone (? Anemone nemorosa).

JACK Jusr ABout. An old country name for the Bird's-foot 'Trefoil, Lotus cornic llatus.

J ACK JuMp Up AND Kiss Me. An old name for the Pansy, Viola arvensis.

JACK OF THE ButTery. Biting Stonecrop, Sedum acre. Dr. Prior says: "A ridiculous name that seems to be a corruption of Bottheriacque to $B$, ttery Jack, the plant having been used as a theriac or anthelmintic, and called Vermicularis, from its supposed vin tue in destroying bots and other intestinal wor.ms."

JACK O' LANTERN (Or LANTHORN). (1) The Wood Anemone, Anemone nemorosa (Ubley and Fiddleford, Dorset).

(2) Hemp Agrimony, Eupatorium cannabinum (Miss Ella Ford, Meiplash).

Jack Run Along by the IIEdge. Garlic Treacle-mustard or Sauce-alone, Sisymbrium Alliaria (Wilts).

TaCk Rux in the Country. Lesser Bindweed Convolv $l$ s ariensis.

JACK RUN IN THE Hedge. Grenter Bindweed, Calystegia sepi m (King's Brompton).

JACK's CHEESES. Seeds of the Common Mallow, Malva sylvestris. See CheEses.

JACK's LAdDer. 'The Scarlet Runner, Phaseolus multiflor's (Dowlish Wake).

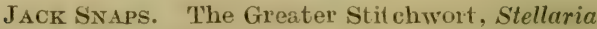
Holostea (South Petherton and King's Brcmpton). See SNAP-JACKs.

JACK SPRAT. The Greater Stitchwort, as above (Barrington). 
JACKY (or JACKY'S) ChEESES. See JACK'S Chemses.

JACOB AND FAMILY. Several young people at Cutcombe give me this as the lceal name of a flower which they can only describe as white and having 12 leaves.

JACOB'S ChARIOT. An old country name for the Monkshood, Aconitum Napell:s.

JACOB's LADDER. A name given to a number of different plants, but apparently most generally to

(1) The Greek Valerian, Polemium cor leum or $P$. album; usually supposed to be so called from its successive pairs of leaflets.

(2) The Gladiolus, both cultivated and wild.

(3) The Larkspur, Delphinium Ajacis.

(4) Solomon's Seal, Polygonatum multiflorum.

(5) The Snapdragon, Antirrhinum majus (Watchet).

(6) The Hollyhock, Althea rosea (South Petherton).

(7) The Lupin, Lupinus (Sampford Brett).

(8) The Balsam, Impatiens $\Lambda$ oli-tangere (Chetnole).

(9) A correspondent at Stalbridge gives it as a local name for the "Spurge," Euphorbia (? species).

JAMr TARTS. (1) Herb Robert, -Geranium Robertianum; and

(2) Dove's-foot Crane's-bill, Geranium molle. Both plants appear to be so named in the Crewkerne and Chard district.

(3) Common Fumitory, Fumaria officinalis (Corfe Mullen).

JAN GRAMFer. Red Campion, Lychnis dioica (from correspondents at Taunt on and Trowbridge).

JAPANESE LANTERN. (1) Cape Gooseberry. See JACK IN A LANTERN.

(2) Canterbury Bell, Campanula medium (Bradford-on-Tone).

JAPANESE Rose. A correspondent at Compton (near Yeovil) gives me this as a local name for the Jew's Mallow, Corchorus olitorius, or $C$. capsularis, the Jute Plant; an Asiatic plant of the Linden family.

Japanese Tea Party. Miss Audrey Vivian, of 'Trowbridge, gives me this as a common name in that district for an Anemone, Anemone japonica, which grows in a semi-wild, or at least unculivated condition, in her own and other gardens.

JAUNDERS Tree. The common Barbary, Berberis vulgaris - from the yellow colour of the wood (West Somerset).

JAUndice Berry. Same as JAUnders Tree. 
JELLY-FLOWER. (1) The common Wallflower, Cheiranthus Cheiri. See GILLIFLOWER.

(2) The Stock, Matthiola incana (Dorset). often called the STOck GILLT-FLowER.

JeLLy STock. A school-boy at Muchelney gives me this as a local name for the Wallflower, Cheiranthus Cheiri.

JENNET, JENNETING. The name of a wellknown Early Apple, commonly said to mean June-eating. Known also as LAMMAs APPLE (F. T. Elworthy). Mentioned by Tennyson in "The Blackbird":-

"Yet, tho' I spared thee all the spring,

Thy sole delight is sitting still,

With that gold dagger of thy bill,

To fret the summer jenneting."

Jenny Cremper. Moneywort, Lysimachia Nummularia. See CREEPING JeNNIE (1).

JENNY Flower. Herb Robert, Geranium Robertianum (Furley). See JENNy WREN.

JENNY GREm-TEETH. A Watchet correspondent gives me this as a local name for a water-plant closely resembling hair. Dr. Watson suggesis probably an Alga, Cladophora glomerata. Dr. R. C. Knight says : "Appears to be one of the Water Milfoils, Myriophyllum species, if it is floating."

JENNy Hood. Herb Robert (East Devon). See JENNY WREN and JoHN HoOD.

JENNy Plant. A Taunton correspondent gives me this as a local name for the Saxifrage (?).

Jenny Wren. The Herb Robert, Geranium Robertianum; a very common name in Taunton Deane.

JERSEY LILY. Vallota purpurea (F. T. Elworthy).

Jerusalem Cowsir. Common Lungwort, Pulmonaria officinalis. See CowsLIP of BEDLAM.

JERUSAREM Cross. Lychnis chalcedonica.

Jerusalem Seeds. Common Lungwort, Pulmonaria officinalis. Mr. Elworthy quotes one as saying: "My mother used to be ter'ble over they JERUSALEM SEEDS vor a arb."

JERUSAlem Stars. (1) The Scarlet Elf-cup Fungus, Geopyxis coccinea (East Somerset).

(2) The Cineraria (Zeals, Wilts).

Jesus' FINGERS AND 'THumbs. A school-girl at Furley gives me this as as a local name for the Kidney Vetch, by which she probably means the Bird's-foot Trefoil. See GOD's FINGERS AND THUMBS.

JEW-BERRY. A common mis-pronunciation. of DEW-BERRY, which see. 
JEW's EAR. (1) A general name for a tough but gelatinous fungus, Hirneola Auricula-Juda, which grows on elder and elm trees, and was formerly used as an ingredient in gargles and as a cure for dropsy. A corruption of Judas-ear.

"For the coughe take Judas eare,

With the parynge of a peare."

(Bale, "Three Laws of Nature, 1562).

(2) The Scarlet Elf-cup, Geopyxis coccinea (Wincanton district).

JEW's EARS. A correspondent at Pilton gives me this as a local name for Dicentra spectabilis; often known as Bleeding Heart, Lyre-flower, Locks and Keys, \&c.

Jibbles. Young Onions. See ChIвble.

JILAFFER. (The syllable aff sounded as in laugh). The Wallflower is known by this name in North Devon. See GHIIfLower.

JHLIFLOWER. SE GHLIFLOWER:

JILL-OFFER. (1) Stocks, Carnations, \&c. (Pulman). See GHAwFER.

(2) Rev. Hilderic Friend says: "In Somerset the Ten-week Stock (Matthiola annua) is called JHOFFER."

(3) The Wallflower, Cheiranthus Cheiri (Somerset and Dorset).

JILOFEER STOCK. Ten-week Stock (Ilminster)

JuLY OFFERS. The Wallflower, Cheiranthus Cheiri (East Mark).

JoB's TEARs. (1) A fairly general name for the Flea-bane, Pulicaria dysenterica, from a tradition that the patriarch Job applied the plant to his boils and obtained relief.

(2) The usual English name for the hard bony seeds of a Grass, Coix tachryma, from a fancied resemblance to tear-drops.

JoE Stanley. The Herb Robert, Geranium Robertianum (from a correspondent at East Lulworth).

JoHs go to Bed AT NooN. (1) A very general form in Dorset for the Yellow Goatsbeard, Tragopogon pratense. See JACK-GO-TO-BED-ATNoon.

(2) Scarlet Pimpernel, Anagallis arvensis (Miss Masey, Taunton).

JoHs HooD. The Herb Robert, Geranium Robertianum (Wells).

JohnNy Cocks. This is given me from Thurlbeare and from several parts of Dorset as a local name for the Early Purple Orchis, Orchis mascula.

JoHNNy MountaIn. When I was a boy at Castle Cary I frequently heard this name applied to Fircones. See DoLLy MLoNTER. 
Johnny Prick-Finger. Common Teasel, Dipsacus sylvestris (Leigh, Dorset).

Johnvy RUN the StReEt. A school-girl at East Mark gives me this as a local name for "Bitty's Eyes," i.e., the Wild Pansy, Viola arvensis.

Johnvy Woods. Red Campion, Lychnis dioica (Netherbury, Dorset).

JoHN's Flower. A correspondent at Wambrook gives me this as a local name for the Shining Crane's-bill, Geranium lucidum.

JoHr's Wort. Mr. Elworthy gives this as a common West Somerset name for the Dwarf Hypericum, $H$. perforatum, more generally known as the Perforated St. John's Wort. Most species of Hypericum are known by the general English name of St. John's Wort. Several botanists question the correctness of Mr. Elworthy's use of the term "Dwarf," and suggest instead "Common" or "Dotted-leaved."

JoInt Weed. Cornfield Horse-tail, Equisetum arvense (West Somerset). Mir. Elworthy says : "This is the name used by 'ginlrokes." 'Mares' tails,' 'Old man's beard,' are the common names."

Joluy Soldiens. Early Purple Orchis, $O$. mascula (Colyford, Devon).

JosepH AND MARY. (1) A fairly general name for the Common Lungwort, Pulmonaria officinalis, the flowers being of two colours, red and blue.

(2) A school-girl at Bradford-on-Tone gives it as a local name for " Spotted Ferns," by which I believe she means the common Hart's-tongue.

Joseph's Coat of Many Colours. Common Lungwort, Pulmonaria officinalis, probably for the reason given under JosepH AND MARY (1).

Joseph's Flower. A name for the Yellow Goat's-beard, Tragopogon pratense, sent me from Wembdon and other districts. Rev. H. Friend says the name seems to owe its origin to pictures in which the husband of Mary was represented as a long-bearded old man.

Jove's Nuts. Acorns. Rev. Hilderic Friend says: "In Somersetshire the Horse-daisy or Ox-eye is devoted to the Thunder god, a curious circumstance when considered in connection with another fact, viz., that Acorns are there called Jove's Nuts. Now we all know that the Oak is emphatically Jove's tree, but how is it that in Somersetshire these two names, not to mention others bearing on ancient religion and mythology, live on when they have died out, or never existed, in other parts of England?"

JoY. Common Eyebright, Euphrasia officinalis (Dunster). 
JoY of THE Mountar. Mrs. Day, of North Petherton, gives me this as a local name for the Marjoram, Origanum vulgare.

JUBILEE HUNTER. The Dewberry, Rubus caesius (N.W. Wilts),

JudAS Tree. (1) The usual English name for Cercis siliquastrum. Mr. Elworthy says: "This tree, and not the elder, seems most widely traditional, as that on which Judas hanged himself. Elders, in this country at least, would hardly be suitable in size or strengtl for the purpose.

(2) A correspondent at Martock gives it as a local name for the T'ulip-tree, Liviodendron tulipifera. Probably due to a confusion of names.

June Fuower. Wild Beaked Parsley, Anthriscus sylvestris (Brompton Regis).

Junetrn. See JenNeT. I am indebted to Mr. 'T. W. Cowan, F.L.S., for the following intere ting note:-Junetin (i.e., Apple of June) seems to be corrupted from geniting, given by Bailey as " a sort of apple." Kettner, Book of the Table, spells it joanneting. The name reminds us of the old custom of naming fruits and flowers from the festivals of the Church nearest to which they ripened or bloomed. June-eating or $S t$. John's apple makes its appearance about Midsummer Day, or the feast of St. John Baptist.

JuPITER's BEARD. (1) 'The Houseleek, Sempervivum tectorum.

(2) Rev. Hilderic Friend says "The Anthyllis or Silver-bush, is commonly called Jupiter's Beard, both in England and Germany." It is also known as JovE's BEARD ; the botanical'name is Anthyllis Barba-Jovis.

Jupiter's StafF. An old name for the Great Mullein, Verbascum Thapsus.

KAMICS or KAMmIK. 'The Rest-harrow, Ononis repens.

KEARN. Seed that is beginning to form or set. Nlso used as a verb. "The wheat is kearning up airly" (Mr. F. W. Mathews).

KECKER, KECKs, or KECKsy. 'The dried hollow stalk of the Cow Parsnip, Heracleum Sphondylium. Also applied to any dried hollow stalks as Hemlock, Chervil, dc. See GIX.

KEDLACK, KEDLOCK, or KETLOCK. Charlock or Wild Mustard, Brassica arvensis. Dr. Watson writes me :- "Ketlock is a fairly general name. In the $\mathrm{N}$. of England, where the old practice of rush-carts (a survival of the time when rushes were carried for carpeting the unflagged floors of the church) is kept up, the body of the rush structure is filled in with ketlocks, chiefly Senecio Jacobcea." 
KEET LEGS. A Sherborne correspondent gives me this as a local name for the Early Purple Orchis, Orchis mascula. I have never known this as a local name, but Dr. R. C. Knight tells me it is given to this Orchis in Kent. It is also applied in that county to $O$. morio. Sometimes used in the form. SKEET-LEGS.

KELP. Seaweed. Always so called-after a storm great quantities are often washed ashore; this is gathered up and used for manure (F. T. Elworthy).

Kenמ⿰亻 . The Rest-harrow, Ononis repens. See CAMMICK and KAMmcs.

Mr. F. T. Elworthy gives this as a West Somerset word meaning a flax-field, and says it is rather a common name of a field.

Kens. Several correspondents send this as a local pronunciation of Cress, in connection with which IIr. T. W. Cowan, F.L.S., kindly points out that Kerse was the Anglo-Saxon name for Water-cress, and quotes:-

"Men witen welle whiche hath the werse, And so to me nis worth a Kerse."

(Gower, M.S., Soc. Autiq.).

KERsting. White Bullace (Devon).

Kersurvs. Small Wild Plums; called also Crislings (West Somerset).

Kestin. A Wild Plum, Prunus insititia (West Somerset). See Buluace.

Ketrue Cases. The Spotted Orchis, $O$. maculata (Sturminster Newton).

Ketthes AND Crocks. The seeds of the Box, Buxus sempervirens (East Mark).

KeтtuE Smocks. (1) Mr. Edward Vivian (Trowbridge) gives me this as a common local name for the small Bindweed, Convolvulus arvensis.

(2) A Stogursey correspondent applies it to the Periwinkle, Vinca, to which $I$ have also heard it applied in other districts.

(3) Mr. W. C. Baker, late of Maunsel, gives it as a local name for the Red Campion, Lychnis dioica.

(4) A correspondent at Chilton Polden applies the name to the Woodbine, Lonicera Periclymenum.

KEX. (1) The dried hollow stalks of certain plants, especially Cow-Parsnip and Hemlock. See GIx and KECKs.

(2) The Wild Carrot, Daucus Carota (Dorset). See CAT.

Kexues. Hemlock, Conium maculatum (Wells). See Kex. (1).

KerbaLL. A Fircone. 
Key Flower. (1) The Cowslip, Primuta veris.

(2) Correspondents at Taunton and Tatworth give it as a local name for the Primrose, Primula vulgaris.

KEY6. The winged seeds of the Ash, Maple, Sycamore, and Lime.

Keys of Heaven. The Cowslip, Primula veris, from the resemblance of its cluster of flowers to a bunch of keys.

KICKs. Stalks of Wild Parsley (G. Sweetman) See KECKS.

Kmney Weed (or WoRT). Wall Pennywort, Cotyledon Umbilicus-Veneris, from a distant resemblance of its leaves to the outline of a kidney.

KIDs. Pods. Also used as a verb. "Beäns be kiddin' well," i.e., the pods are filling (Mr. F. W. Mathews).

KHK. A number of school-children at Aller give me this as a local name for the Charlock or Wild Mustard, Brassica arvensis.

King Charles' OAK. This name is frequently given by school-children to the Brake or Bracken, Pteris aquilina, for the reason that if the portion. of the stem which grows just below the surface of the earth is cut across with a sharp knife the figure of an oak tree may be seen.

KING CUP. (1) A very general name for Marsh Marigold, Caltha palustris.

(2) Also given to several species of Buttercup, particularly to the Meadow Crowfoot, Ranunculus acris.

(3) The Lesser Celandine, Ranunculus Ficaria.

(4) The European Globe-flower, Trollius europaeus (F. T. Elworthy).

Probably 2,3 , and 4 are all due to confusion with No. 1.

Krng Kongs. Marsh Marigold, Caltha palustris (Oakhill and C'rewkerne).

KINGS AND QUEENS. Wild Arum or Cuckoopint, Arum maculatum (Sexey's School and Stockland, Devon). More frequently called LORDS AND LADIES.

KING'S ClaAver OR ClOVER. Common Yellow Mrelilot, Melilotus altissima.

KING's Cross. The Wallflower, Cheiranthus Cheiri (from an Ilminster school-girl).

KING's Crown. (1) Red Clover, Trifolium pratense (Wiveliscombe).

(2) The Guelder Rose, Viburnum Opulus (Cotswolds).

(3) Mr. T. W. Cowan, F.L.S., tells me that in some parts the Melilot, Melilotus, is known by this name. 
KIvg's Evr. Mrs. Day, of North Petherton, gives me this as a local name fol the Lesser Celandine, Ranunculus Ficaria.

King's KnoBs. The Bulbous Buttercup, Ranunculus bulbosus.

KING's Spear. (1) The Daffodil, Narcissus Pseudo-Narcissis.

(2) The Yellow Asphodel, Asphodelus luteus.

Kryg's TAper. Great Mullein, Verbascum Thapsus.

King's Wine-glass. The Tulip, Trulipa Gesneriana.

Kiss AND Go. The Mistletoe, Viscum album (Miss Ella Ford, Melplash).

Kiss Behind the Garden Gate. London Pride, Saxifraga umbrosa (S.W. Wilts, Somerset border).

Kiss Behind the Paxtry Dook. Red Spur Valerian, Kentranthus ruber (a correspondent at Wells).

Krsses. (1) The Goose-grass, Galinm Aparine.

(2) The Burdock, Arctium minus, and particularly to the sticky seeds in each case.

Kissing KInd. Red Spur Valerian, Kentranthus ruber (Portland).

KIss ME. Rev. Hilderic Friend says he has heard the Herb Robert, Geranium Robertianum, so called in Devon, and quotes Mr. Britten, who stated that in South Bucks this flower is known by the name of KISS ME Love AT THE GaRden Gate.

Kiss ME AND Go. The Southernwood or Boy's-love, Artemisia Abrotonum.

Kiss Me Behind the Garden Gate. Wild Pansy, Viola arvensis (Devon).

Kiss Me Love at the Garden Gate. (1) London Pride, Saxifraga umbrosa (Devon). The name is frequently reduced to GARDEN Gate, which see.

(2) Wild Pansy, Viola arvensis (Devon).

KISS ME Not. A correspondent at Dunster gives me this as a local name for the London Pride, Saxifraga umbrosa.

KIss ME Quick. This name is given to a large number of flowers, but most generally throughout Somerset, Dorset, and Wilts to.

(1) The Red Spur Valerian, Kentranthus nuber.

(2) In Devon and West Somerset most generally to the London Pride, Saxifraga umbrosa.

(3) The Pansy, both wild and cultivated, Viola arvensis and $V$. tricolor (Taunton and West Somerset). 
(4) Sweet Woodrufi, Asperula odorata (North Somerset and Dorset).

(5) Meadow-sweet, Spirce Ulmaria (Odcombe and Bradford-on-Tone).

(6) White Forget-me-not, Myosotis dissitiflora alba (Chew Magna).

(7) The Herb Robert, Geranium Robertianum (Camerton, and Dorset and Devon).

(8) Goose-grass or Cleavers, Gulium Aparine (Sexey's School and Curxy Mallet).

(9) The Burdock, Arctium minus (Sexey's School).

(10) The Bladder Campion, Silene latifolia (Over Stowey).

(11) Love-lies-blesding, Amaranth:s candatus (Odcombe and Broadstone).

(12) Southernwood or Boy's-love, Artemisia Abrotomum (Taunton).

KISS ME Quick AxD Go. Southernwood or Boy's-love, Artemisia Abrotonum (Devon).

KISS THE GARDEN DoOR. Mr. F. W. Mathews tells me that in Mid-Dorset this name is given to the Red Spur Valerian, Kentranthus ruber, more commonly known as KISS-ME-QUICK.

Kite's PAx. Spotted Orchis, Orchis maculata (S.W. Wilts, Farley).

KIT RUN THE FIELDs. An old name for the Wild Pansy, Viola arvensis.

KrTtens' 'Tarls. Catkins of Hazel, Corylus Avellana (Charmouth).

KrTTY KEYs. The red bunches of fruit of the Mountain Ash or Quickbeam, Pyrus Aucuparia (West Somerset).

Kitty Run the Street. Wild Pansy, Viola arvensis (Chilmark, Wilts).

Kitty Two-Shoes. Bird's-foot Trefoil, Lotus corniculatus (Sherborne).

KNEE Holly, Holm, or HÚlver. Old popular names for the Butcher's Broom, Ruscus aculeutus.

KNIFE AND FORK (or KNIVES AND Forks). A fairly common name for the Herb Robert Geranium Robertianum, particularly in the Taunton and West Somerset district.

KNIGHTS AND LADIES. A correspondent at Cerne Abbas gives me this as a local name for the Wild Arum or Cuckoo-pint, Arum maculatum, more generally known as LoRDs AND LADIES.

KNoBbed StICK. A schoolgirl at Paulton gives this as a local name for the single Tulip.

KNoвs (or NoBs). Apples (Thorne St. Margaret).

KNOB-WEED (or KNOP-WEED). Another form of the name Knapweed, Centaurea. 
KNot-GRAss. The genteel name for Polygonum aviculare; more commosly known as MAN-TIE or TACKER-GRASS (F. T. Elworthy).

KNot-WEED. Common Knot-grass, as above. In some counties Centaurea nigra $C$. Cyanus and $C$. Scabiosa are called KNOT-WEED.

Kramics. The Rest Harrow, Ononis repens. See CAмпMCK and KaMnICK.

LACE. (1) Wild Parsley (Bruton (listrict). (2) Chervil (Axminster district).

Lace Curtains. Fool's Parsley, Ethusa Cynapium (a school-girl at Ilminster).

Lace Flower: (1) "Pig's Parsley," Caucalic Anthriscus (Fivebead).

(2) Hemlock, Conium maculatum (Horton).

LADDER LOVE. A correspondent at Ditcheat gives me this as a local name for the "Cornflower Knapwaed," Centaurea Cyanus.

LADDER to Heaven. An old country name for the Lily of the Valley, Convallaria majalis.

LADIES AND Genthemen. (1) Wild Aruma or Cuckoo-pint, Arum maculatum, more often called LORDS AND LADDES.

(2) Wild Pansy, Viola arvensis (particularly Grewkerne district).

LADIES IN A SHIP. Monk's-lrood, Aconitum Napellus (Brompton Regis).

LADIES IN THE HAY. Woodruff, Asperula odorata (Donhead, Wilts).

Ladies in the Shade. The Fennel Flower, Nigella damascena, more commoniy called Love IN A MIIST (Martock).

Ladies IN White. London Pride, Saxifraga umbrosa (Wilts).

LAD's Love. Southernwood, Artemisia Abrotonum, more commonly called BOY'S-LOVE.

LADX's. When this word formas part of a plant's name it may be assumed that it refers to "Our Lady" - the Virgin Mary. In days of old, Monks and Nuns were fond of dedicating all sorts of flowers to her, but it is not always easy to see how the second part of the name applies.

LADY BETTY. Laurustinus (Lovington). Viburnum 'Tinus.

LADY-BHDD. Scarlet Pimpernel, Anagallis arvensis (Culmhead).

LADY-BIRD'S REST. A school-boy at Evercreech gives me this as a local name for the "Meadow Sage" but as this plant is extremely rare and does not grow anywhere near Evercreech there is apparently some confusion of 
name. Probably he means the Wood Sage, Teucrium Scorodonia, which is common in that district.

Lady Eleven o'Clock. The Star of Batblehem, Ornithogalum umbellatum. See "ELEvEN O'ClOCK LADY."

Ladx In Stockings. White "Hose in Hose" Polvanthus (Maunsel).

LADY IN THE BOAT. Dicentra spectabilis, more commonly known as LADY's LockETs, BLEEDING HEART, LYre Flower, and many other names (Maunsel).

LAdy JAnes. Herb Robert, Geranium Robertianum (Charmouth district).

Lady Lavinia's Dove Carriages. Monk'shood, Aconitum Napellus (Rampisham, Dorset).

Lady Mary's Tears. Miss Ida Roper, F.L.S., tells me that the Common Lungwort, Pulmonaria officinalis, is known by this name in Dorset.

Ladr Nut. Spanish Chestnut, Castanea vesca (East Somerset).

IADY OF Spring. Dandelion, Taraxacum officinale (Miss Ella Ford, Melplash).

LADY OF THE LAKE. White Water Lily, Nymphaca alba.

LADT OF THE MEADow. Meadow-sweet, Spircea Ulmaria. More often called QUEEN of THE MEADOW. alba.

LADY OF THE Woods. White Birch, Betula

LADY RUFFLES. A school-girl at East Mark gives me this as a local name for the "Campanula" (?)

LADY's BAGs. The Calceolaria (Chard). More often called LADY's PockETs.

LADY's Barts. Black Knnapweed, Centaurea nigra (S.W. Wilts, Charlton).

LADY'S BED. A correspondent at Axminster gives me this as a local name for the Lady's Bedstraw, which see.

LADY's BEDSTRAw. The general English name for Galium verum. Dr. Prior says: "From its soft puffy floccclent stems and golden flowers -a name that refers to straw having formerly been used for bedding, even by ladies of rank."

LADY's Bonnets. The Columbine, Aquilegia vulgaris (West Pennard), more generally called GranNy's (or GraNDMOTHER's) BonNETS.

LADY's Boots. Bird's-foot Trefoil, Lotus corniculatus (Rev. H. Friend). 
LADY's Bower. IVild Clematis or 'Thaveller's Joy, Clematis Vitalba; more often celled VIRGIN's BOWER.

LADY's BRUsh AND Comb. Common Teasel, Dipsacus sylvestris (Bradford-on-Tone).

LADY's Breshes. 'Teasel, as above (East Mark).

LADY's ButToxs. Greater Stitchwort, stellaria Holostea.

LAdy's BuNch of KeYs. The Comslip, Primula veris (Wiveliscombe).

LADY's CANDLE. Great Mullein, Verbascum Thapsus. See HIG TAPER.

LADX's CHAIN. Laburnum (particularly Dorset and Devon). More generally called GoLden Chain.

LADY's GHemse. (1) Greater Convolvulus or Hedge Bindweed, Calystegia sepium.

(2) Greater Stitchwort, Stellaria Holostea (Bruton and Wincanton).

(3) Wood Anemone, Anemone nemorosa (Wincanton).

LADY's CLOAK. Cuckoo-flower, Cardamine pratensis (Sexey's School). More generally called LADY'S SMOCK.

LADY's CUshiox. (1) 'The Sea-pink or Thrift, Staice maritima. Wilts).

(2) Kidney Veteh, Anthyllis Vulneraria (S.W.

(3) Bird's foot Trefoil, Lotus comiculatus (Wills and Devon).

LADY'S EAR-DROPS. (1) A very general name for the Fuchsia.

(2) A correspondent at Pilton gives it as a local name for Dicentra spectabilis.

LADY's FINGER (or FINGERs). A name given to a number of different flowers, but most generally to

(1) The Kidney-vetch, Anthyllis Vulneraria:

(2) Birl's-foot Trefoil, Lotus comiculatus.

(3) The Foxglove, Digitalis purpurea.

(4) Early Purple Orchis, Orchis mascula.

(5) Wild Arum or Cuckoo-pint, Arum maculatum.

(6) Common Groundsel, Senecio vulgaris (Trowbri(lgc).

(7) A school-girl at Bradfocd-on-Tone gives it as to local name for the Cinquefoil.

(8) Tufted Horso-shoe Vetch, Hippocrepis comosa (N. and S.W. Wilts).

(9) Meadow Vetchling, Lathyrus pratensis (N. and S.W. Wilts occ asionalls).

(10) Slow's Glossdry of Wiltshire Words sives it as a lo al name for the "Will Calceolaria" (?) 
Lady's Fingers and 'Thumbs. Bird's-foot 'Trefoil, Lotus corniculatus.

LADY'S GARTERS. The common guden striped Ribbon Gras.. Digraphis or Phalaris arundinacea. Kno.vn , lso as LADY'S LACES and LADY's RIBANDS.

LADY's GLoves. (1) Miss Ella Ford, of Melplash, gives me this as a local name for the Bird's-foot Trefoil, Lotus comiculatus, and it is give. in the Wiltshire Glossary as a name in S.W. Wilts for the "Greater" Bird's foot," Lotus uliginosus.

(2) The Foxglove, Digitalis purpurea (Dor'set).

(3) In some places the name is given to the Canterbury Bell. Campanula media; also to

(4) Ploughman's Spikenard, Inula squarrosa.

LAdy's Grass. (1) Same as LADy's Garters. (2) A Maize, Zea japonica (Rev. H. Friend).

LADY's HAIR. (1) Quaking Grass, Briza media (Watchet, Bradford-on-Tone, and Queen Camel).

(2) Wiall-1ue, Asplenium Ruta-muraria (Rodney Stoke).

LADY'S HAT-PINS. Several young people in the Axmisster ciistrict give me this as a local name for the Field Scabious, Scabiosa arvensis.

LADY'S HEART. Dicentra spectabilis, known also as BIEEDING IIEART, LADY's LOCKETs, and by many other names.

LAdy's Kexs. (1) The Cowslip, Primula veris (Sampiord Brett). 'The Cowslip is also know $n$ by this name in Germany.

(2) The fruit of the Sveamore, Acer Pseudoplatenuis (Chilmark, Wilts).

LAdy's KNIVES and ForKs. Common Clubmoss, Lycopodium clavatum. Very common on Dunkery and Porlock Hil!. Kriown also as Stag's-HORN MOSS.

LADY's LACE. (1) Fool's Parsley, Ethusa Cynapium (Sexey's School).

(2) Hedge Parsley, Cancalis Anthriscus

(3) Ifemlock, Conium maculabm (South Somerset).

LAdX's LACES. (1) The Dodder, Cuscuta Epithymum.

(2) Sime as Lady's Garbers.

LADY's LINT. 'The Greater' Stitchwort, Stellaria Holostea. Britten says "probably from the white threads in the centre of the stalks" ; but other's consider it more probally from the whiteness of the flowers, like a pateh of lint ready for it wound. 
LADY's Lockets. (1) Dicentra spectabilis. Known also as the LYRE-FLOWER and BLEEDING HEART.

(2) Solomon's Sexl, Polygonatum multiflorum (Compton, near Yeovil).

(3) Honesty or Luuary, Lunaria biennis (West Bradley). More generally called MONEY-IN-BOTHPockets.

(4) Seeds of the Mtple, Acer campestre (Curry Millet).

(5) Common Fumitory, Fumaria officinalis (Barington).

LADY's MANTLE. (1) 'The general English name for Alchemilla vulgaris.

(2) Bitter-cress or Cuckoo-flower, Cardamine pratensis (Sexey's School).

(3) A correspo rdent at Wellington gives it as a local name for the Nioschatel, Adoxa Moschatellina.

(4) A school-boy at Evershot gives it as a local name for the Ribwort Plantain, Plantago lanceolata.

LADY's MuK-CANS. Wood Anemone, Anemone nemorosa (Stalbridge).

LADY's MILKING-STOOLs. A school-boy at Stalbridge gives this as a local name for the Lesser Stitchwort, Stellaria graminea.

Ladr's Navel. The Wall Pennywort, Cotyledon Umbilicus-Veneris.

LADY's NeEDLEWORK. (1) Red Spur Valerian, Kentranthus ruber.

(2) Snow on the Mountain, Alyssum maritimum.

(3) Woodruff, Asperula odorata.

(4) Greater Stitchwort, Stellaria Holostea (Bridgwater and Ilton).

(5) Mr. W. S. Price, of Wellington, gives it as a local name for the Garde Seabious, Scabiosa atropurpurea.

(6) Hemlock, Conium maculatum (Martock).

(7) Garlic Treacle-mustard or Jack-by-theHedge, Sisymbrium Alliaria (Milborne Port).

LAdr's Nightcap. Gieater Bindweed, Calystegia sepium.

LAdY's PetTicoat. (1) Wood Anemone, Anemone nemorosa (Mere, Wilts).

(2) The Columbine, Aquilegia vulgaris (Evershot).

Lady's Pincushion. (1) Garden Scabious, Scabiosa atropurpurea (Mr. W. S. Price, Wellington).

(2) Field Scabious, Scabiosa arvensis (Curry Mallet).

(3) Kidney Vetch, Anthyllis Vulneraria(Wilts).

(4) Yellow Fumitory, Corydalis lutea (Devon). 
LADY's Pockets. The Galceolaria.

LADY's Posres. Red Clover, Trifolium pratense (Cur- $y$ Mallet).

LADY's PRIDE. A school-girl at Churchstanton gives me this as a local name ior the Cuckooflower, Cardamine pratensis.

LAdY's PURse. (1). The Culceolaria (East Lydford).

(2) The Columbine, Aquilegia vulgaris (Cerne Abbas).

(3) Dicentra spectabilis (Bridgwater).

LADY's REST. Another school-boy at Evercreech gives me this as a local name for the Sage "Meadow." See LADY-BIRD's REST.

LADY'S RIBANDS. See LADY'S GRass.

LADY'S Roses. A Taunton lady gives me this as a local name for the small Yellow Chrysanthemum.

LADY's RuFfles. The double Wbite Narcissus (N.W. Wilts).

LADY'S ScENT-BotTLE. The Stock, Matthiola (Aller school-boys).

Ladr's Seal. (1) Solomon's Seal, Polygonatum multiflorum.

(2) Black Bryony, Tamus communis.

LADY's Shrmanes. See Lady's CheMrise (1).

LADY's SHoz. (1) Common Fumitory, Fumaria officinalis (S.W. Wilts).

(2) A Wincanton school-girl gives this as a local name for the Lady's Snock, Cardamine pratensis.

LaDX's Shoes. The Columbine, Aquilegia inigaris (Nettlecombe and East Mark).

LAdY's SHoes AND Stockings. Bird's-foot Trefoil, Lotus corniculatus.

LADY's SLIPPER. A name given to a number of different plants, but most ge zerally in this district to the

(1) Bird's-foot Trefoil, Lotus corniculatus.

(2) Monk's-hood, Aconitum Napellus.

(3) The Mealow Vetchling, Lathyrus pra!ensis (Wells, Castle Cary, and Wilts).

(4) Meddow Buttercup, Ranunculus acris (sent me by a correspoudent at Otterford, and also recorded from Wells by Rev. R. P. Murray).

(5) Foxglove, Digitalis purpurea (correspondents ot Yeovil and Axbridge).

(6) Tufted Horse-shoe Vetch, Hippocrepis comosa (Wilts).

(7) Columbine, Aquilegia vulgaris (Chilton Polden and Trowbridge).

(8) Broom, Cytisus scoparius (Ubley).

(9) Calceolaris (Wellington) 
(10) Lupiss, Lupinus (Martock;.

(11) Itis (Wiveliscombe).

(12) Yellow Toadflax, Linaria vulgaris (Martock).

(13) Suapdragos, Antirrhinum majus (Gillinghama).

LADY'S Smock. Another name in hich is applied to several differeat plants, but most generalis to

(1) The Common Bitter-ciess or Cuckooflowel, Cardamine pratensis.

(2) A number of correspondents, ehiefly in Dorset, but including one at Bradiord-on-Tone, give this as a local name for the Cuckoo-pint, Arum maculatum. Holloway gives the name as being applied to this flower in Hants.

(3) Greater Convolvulus or Hedge Bindweed, Calystegia sepium (fairly general).

(4) Lesser Convolvulus or Bindweed, Convolvulus arvensis (Melbury Osmond).

(5) Greater Stitchwort, Stellaria Holostea (Leigh, Dorset).

LAdy's Sunshades. Lesser Convolvalus, Convolvulus arvensis.

LADY's TAPER. Gieat Mullein, Verbascum Thapsus.

LAdy's.Tears. Lily of the Valley, Convallaria majalis (two correspondents in the Axminster district).

LAdY's 'THnmbe. (1) The Foxglove, Digitalis purpurea.

(2) The pretty blue Harebell, Campanula rotundifolia (West Somerset). Rev. H. Friend says: "The flowers of the Campanula are called LADY's THmBles around Martock and Yeovil," and again "The Virgin is expected to repair her own ilothes, for in Somersetshire my friends told me that they found her in thimbles in the shape of the flowers of the Campanula." Mr. W. D. Miller suggests that the Campanula to which Mr. Friend reters must be some other than $C$. rotundifolia, which he tells me occurs very sparingly on Ham Hill, and is not recorded elsewhere in the neighbourhood of Martock or Yeovil. He adds, "It is far too rare a plant to have a pet name."

(3) A school-girl at Otterford gives this as a local name for the Canterbury Bell, Campanula media.

(4) Greater Stitcinwort, Stellaria Holostea (Leigh, Dorset).

LADY's Thistue. The Milk Thistle or Virgin Mary's 'Thistle, Silybum Harianum, from a superstitious belief that the numerous white spots with which the leaves are beautifully marked were caused by the falling of some drops of the Virgin Mary's milk upon them. 
LADY's Thuarbs AND Fingers. Corlesponlents at: Stalbridge and Okeford Fitzpaine give this as the local name of the Bird's-foot Trefoil, Lotus corniculatus. More generdlly called Frvgers AND THUMBS.

LADY's Tresses. (1) The goner-x] English name for the Orcnil group, Spiranthes, from the flowers on the spike being like braided hair.

(2) A lady at Clifton several years ago gave me this ds a local name for the Cuckoo-pint, Arum naculatum. It is difficult to see the reason, but she give a number of other names correctly.

(3) A lady at Stalbridge gave me this as a local name for the Yellow Bedstraw, Galium verum.

LADY's UMBRELlas. (1) Greater Convolvulus Calystegia sepium (Aller school-boys).

(2) Lesser or Field Convolvulus, Convolvulus arvensis (Laigh, Dorset).

(3) Wocdy Night-shdde, Solanum Dulcamara (Curry Mallet).

LADx WHIN. Au old country name for tre Rest Harrow, Ononis repens.

LADY WHIT-SMOck. White Brompton Stock (Maunsel).

LAMB IN A PULPIT. Wild Arum or Cuckoo-pint, Arum maculatum. Given by Rev. H. Friend on the autherity of Britten. A lady at East Grimstead, Wilts, gives me LAMB IN THE PULPIT as being used in that distriet.

LAMBriss. Hazel Catkins (Barford St. Martin, Wilts).

LANB'S EARs. (1) A school-girl at Queen Camel gives me this as a local name for the Red Dead Netile, Lanium purpureum.

(2) A correspondent at Wellington gives it as a local name for the Silver-weed, Potentilla Anserina.

LAarB's Foot. Kidney Veteh, Anthyllis Vulneraria (Evershot).

LAmB's Grass. Spring grass ; early grass, as distinguished from ee-grass (Dorset).

LAJiB's LETTUCE. (1) An old name for the Common Corn Salad, Valerianella olitoria.

(2) A school-girl at Queen Camel gives it as a local name for the Nipplewort, Lapsana communis.

(3) A school-girl at Oake gives it as a loca name for the Salad Burnet, Poterium Sanguisorba.

LAJiB's QUARTERS. (1) Common Goosefoot, Chenopodium album.

(2) The Common Orache, Atriplex patula. Dr. Prior thinks this is perhaps only Lammas quarter, called so from its blossoming about the 1st of August, the season when the clergy used to get in their tithes. 
LAMB's TaILs. Catkins of almost every kind, but more particularly those of the

(1) Hazel, Corylus Avellana.

(2) Those of various kinds of Willow, Salix.

(3) Those of the Alder, Alnus rotundifolia (Sampford Arundel).

(4) Ribwort Plantain, Plantago lanceolata (East Somerset).

(5) In some places this name is given to the Kidney Vetch, Anthyllis Vulneraria, more often called LADY'S FINGERS.

LamB's T'oE. (1) Bird's-foot Trefoil, Lotus corniculatus.

(2) Correspondents at Taunton and Sampford Arundel give it as a local name icr the Kidney Vetch, Anthyllis Vulneraria, and $\mathrm{Mr}$. T. W. Cowan tells me this is a well-known name for the plant in many places.

LAam's Tongue. (1) The Hoary Plantain; Plantago media, from the shape of the leaf.

(2) The Ribwort Plantain, $P$. lanceolata.

(3) Common Goosefoot, Chenopodium album.

(4) The woolly-leaved garden plant, Stachys lanata, often called DoNkEx's-EAR and MoUsE'sEAR.

(5) The Hart's-Tongue Fern, Phyllitis Scolopendrium (West Somerset).

(6) A school-girl at Bradford-on-Tone gives it as a local name for the Yellow Rattle, Rhinanthus Crista-galli.

(7) Several school-girls at Horton give it as a local name for "Rabbits" ears" (?) Is this the same as No. 4 ?

LAMB TONGUE. (1) The usual name in West Somerset for the common Hart's-tongue Fern (F. T. Elworthy). See LamB's Tongue (5).

(2) "A very common weed, Chenopodium urbicum. Always" (F. T. Elworthy). The Rep. W. P. Murray suggests that this is a mistake for the Red Goosefoot, $C$. rubrum, as $C$. urbicum is very rare. Dr. Watson considers it most probable that $C$. album is the plant referred to.

LAMMAS APPLE. A well-known early apple, so called from its ripening about Lammas Day, August 1st. Known also as JenNeting.

LAMmINT. (1) A contraction of Lamb Mint, Mentha viridis (Rev. H. Friend).

(2) Frequently applied to the Peppermint, Mentha piperita.

LAMPS of Scent. A Taunton lady gives me this as a local name for the Woodbine or Honeysuckle, Lonicera Periclymenum.

LAND Cress. (1) Several correspondents in Somerset and Devon give me this as a local name for the Common Winter Cress or Yellow Rocket, Barbarea vulgaris.

(2) Dr. Watson gives it as a local name for the Hairy Bitter-cress, Cardamine hirsuta. 
LAND ROBBER. "Butterdock (called by the country people the land robber)." Diogenes" Sandals, p. 135 (Wilts Glossary). Mr. T. W. Cowan tells me this no doubt refers to Rumex obtusifolius, of which one of the ccmmon names is ButTer Dock or BATTER Dock. Dr. Watson suggests it may refer to the Butterburr.

Lantern Leaves. The late G. P. R. Pulman gives this as a local name for the Ram's-claw Buttercup, Ranunculus repens.

LaRger Sunshade. Hedge Convolvulus, Calystegia sepium (Staple Fitzpaine).

LARK-HEEL. A lady at Compton (near Yeovil) gives me this as a local name for the Nasturtium. In other places the Larkspur, Delphinum, is sometimes called LARK'S-HEEL and LARK'S-CLAW.

LARK'S-SEED. Greater Plantain, Plantago major (Charlton, Wilts).

LARK's-EYES. (1) Correspondents at Bradford-on-Tone and Winscombe give me this as a local name for the Wild Pansy, Viola arvensis.

(2) Mr. W. C. Baker, late of Maunsel, gives it as a local name for the Germander SpeedweU, Veronica Chamodrys, more generally called BIRD'S-EYES.

LAST Flower OF SUMMER. Michaelmas Daisy, Aster Tradescanti (Camerton). Compare FARETELLL SUMMER and SUMMER'S FAREWELL.

LAST Rose OF SUMMER. Michaelmas Daisy, as above (Compton, near Yeovil).

LAdGHter Bringer. Two Taunton ladies give me this as a local name for the Scarlet Pimpernel, Anagallis arvensis.

LAUREe TINY. A correspondent at Glastonbury gives me this as a local name for the Spurge Laurel, Daphne Laureola. Dr. Watson suggests there may be some confusion here, and that the Laurustinus, Viburnum Tinis, is intended.

Lauristina. Mrs. H. Day, of North Petherton, gives me this as a "Petherton" name for the Guelder Rose, Viburnum Opulus.

LAVENDER. Several school-boys at Evercreech give me this as a local name for the "Pink Persicaria," no doubt Polygonum Persicaria ; often known as RED LEGS.

LAVER. The fronds of certain marine algæ (seaweeds), used as food and for making a sauce called Laver Sauce. Mr. T. W. Cowan tells me that Green LAVER is Ulva latissima, and PURPLE LAver is Porphyra vilgaris. Hr has seen both exposed for sale in Torquay and other places.

LAvers. The Yellow Iris, Iris Pseudacorus (Dorset). See Levrers. 
LAWYER WEED. This strange name for the common Buttercup is given me by a school-boy at Draycott.

LAY-A-BED. The Daudelion, Taraxacum officinale (Evercreech). See LIE-A-BED.

LAYLock. A very general corruption of Lilac, Syringa vulgaris. MI. T. W. Cowan tells me that the words "Sweet LAYLocks bloomed" occur in the Scotch ballad, "Twas within a mile of Edinboro toon."

LAZARUS BELL. In some parts of Devonshire the Snake's Head Fitillary, Fritillaria Meleagris, is known by this name, and also as LEOPARD's LILY (which see). It is probable that both names come down to us from the days when leprosy was a common disease in this country and the leper or "lazar" had to carry a warning bell with him. The shape of the flower somerhat resembles that of a bell.

LAZY-BONES. The "Barren Strawberry's (Strawberry-leaved Cinquefoil), Potentilla sterilis (Miss Ella Ford, Melplash).

LEATHERs. A Taunton lady gives me this as a local name for the Yellow Iris, Iris Psendacorus. See LEVVERS.

LEGWORT. I correspondent at Wambrook gives me this as a local name for the Lesser Gelandine, Ranunculus Ficaria.

Lemonade. Mr. F. R. Summerhayes, of Milborne Port, gives me this as a local name for the Agrimony, Agrimonia Eupatoria, no doubt in consequence of the lemon-like perfume given off by the plant.

LenoN FLower. The Agrimony, as above (South Petherton).

Lemon Plant. The sweet-scented Verbena, Aloysia citriodora.

Lent Cocks. An old name for the Daffodil, Narcissus Pseudo-Narcissus. "In allusion, it seems, to the barbarous custom of cock-throwing, which was prescribed by our forefathers for Lont, or rather for Shrove Tuesday. The boys, in the absence of live cocks to throw sticks at, practised the art of decapitation on the flower.'

LENTEN LILY. A less common form of LENT LILY.

LENT LILY. A very general name for the Daffodil, Narcissus Pseudo-Narcissus.

Lent Pitcher. The Daffodil as above (West Somerset and Devon).

Lent Rose. (1) The Dafiodil. See LENT LILY.

(2) Also Narcissus biflorus. 
(3) Two school-girls at Stockland (Devon) give me this as a local name for the Primrose, Primula vulgaris.

LENTy Cups. The Daffodil, Narcissus PserdoNarcissus (Bishop's Lydeard).

LEOPARD's BANE. (1) The general English name for the genus Doronicum, particularly for D. Pardatianches.

(2) This name is sometimes given to the Herb Paris, Paris quadrifolia.

LEOPARD's LImY. The Snake's Head Fritillary Fritillaria Meleagris. Mr. R. J. King, in Trans. Devon Assocn., IX., 101-2, suggests the name is a corruption of Leper's Lily, and that Lazarus Bell is "Lazar's Bell," from its likeness to the small bell which the lazar was bound to wear on his person so that its tinkling might give warning of his approach.

LEOPARD's TONGUE. A school-girl at Chewton Mendip gives me this as a local name for the Hart's Tongue Fern, Phyllitis Scolopendrium.

LEST WE ForgeT. A school-girl at Bradfordon-Tone gives me this as a local name for the Mignonette, Reseda odorata.

LeVer BLossom. This is sent me by a schoolgirl at East Mark as a local name for the Yellow Flag, Iris Pseudacorus.

LEVERS. (1) Halliwell's Dictionary gives this as a South of England name for the Yellow Flag. See above. It is sent me from several parts of Dorset.

(2) A species of rush or sedge (Rev. W. P. TVilliams). Dr. Watson says, "Probably Carex acutiformis and $C$. riparia," and adds, "The name seems to refer really to the Yellow Flag, and to have been extended to other marsh plants having similar leaves."

LeVvers. (1) The Great Yellow Flag, Iris Pseudacorus (Somerset and Dorset).

(2) A name given in some parts of Somerset to the Reed-mace, Typha latifolia, more commonly called Bulrush. Rev. Hilderic Friend says "Since the name of Bulıush has been given to the Juncus by the people of Somersetshire, it was necessary that they should designate the Reed-mace by some other name; and they accordingly used the word LEVVERs."

(3) A coarse marsh grass, Poa aquatica, often called SwORD-GRASS or IVTTHERS (Somerset Marshes).

LICK. A mispronunciation of Leek, common in Somerset and Devon.

IIE-ABED. (1) A number of young people at Paulton give me this as a local name for the Dandelion, Taraxacum officinale. See LAY-ABED. 
(2) An equal number c f Paulton correspondents give the name to the Hawkbit, Leontodon.

LIFE OF MAX. His Honour J. S. Udal gives this as a Dorset name for the Spiderwort, Tradescantia virginica.

LIGHTNLNG FLowER. An old country name for the Scarlet Field Poppy, Papaver Rhoeas, from a curious superstition among children that if they pick it and the petals fall off, as they are apt to do, the children are then liable to be struck by lightning.

Lmac FLower. Two school-girls at Ilminster give me this as a local name for the Water Mint, Mentha aquatica.

LIIY (or LIIIES). (1) An Ilminster school-girl gives me this as a local name for the Purple Iris.

(2) In S.W. Wilts the name is given to the Hedge Convolvulus, Calystegia sepium. Compare BINE-LILIES.

(3) Wild Arum or Cuckoo-Pint, Arum macuatum (Barfcrd, Wilts).

LIUY CoNfancy. A Martock school-boy gives me this as a local name for the Lily of the Valley, Convallaria majalis.

LIMTERN-SCRIMT, LIMPER-SCRTMP, and LIMPETScrnMP. Three of the commonest forms of the most general name in West Somerset for the Cow-parsnip c r Hogweed. Heracleum Sphondylium. See LUMPER-SCRUMP.

LIMPETS-CrRarP. A lady at Kilton gives nae this as a local name for the common Duckweed, Lemna minor.

LINEN Butrons. The Lily of the Valley, Convallaria majalis (a school-girl at Ilminster).

LIox's Fоoт. Common Lady's Mantle, Alchemilla vulgaris.

LION's MouTH. (1) A fairly general name for the Snap-dragon, Antirrhinum majus, which is also called in some parts of the country LION's LEAF.

(2) Yellow Toad-flax, Linaria vulgaris (Axminster district).

LIoN's PAw. Same as Lron's Foot.

LION's SNAP. Two school-girls at Queen Camel give me this as a local name for the Yellow Dead Nettle, Lamium Galeobdolon.

LION's TEETH (or TooTH). (1) The Dandelion, Taraxacum officinale. The generic name of this plant was formerly Leontodon, which is now reserved for the Hawkbit group, and which means Lion's Tocth. The English name, Dandelion, comes frcm the French dent de lion, and means the same. It is said that the plant bears an equivalent name in nearly every country in Europe.

(2) A schonl-girl at Chewton Mendip gives it as a local name for the Wild Lettuce, Lactuca muralis. 
Lion's Toxgues. (1) Two school-girls at Upottery give this as a local name for the Yellow Toad-flax, Linaria vulgaris. See LIon's Hotth (2).

(2) A school-girl at Paulton gives it as a local name for the Hart's 'Tongue Fern, Phyllitis Scolopendrium.

LIQUORICE PIANT. A correspondent at Dunster gives me this as a local name for the Common Rest-harrow, Ononis repens, which is frequently known as Wild Liquorice. Anne Pratt says: "The long roots have the sweet flavour of liquorice, and are sucked both by children and country labourer's to quench thirst."

LTTTLE AND PRETTY. (1) A common name in many parts of Somerset, particularly in the Eastern portion of the country, for the Virginian Steck, Malcolmia maritima. I also have the name from Dorset, Devon, and Wilts, but to nothing like the same extent as from East Somerset.

(2) London Pride, Saxifraga umbrosa (chiefly in Dorset, but the Rev. H. Friend gives it as used in Devon).

(3) A Yeovil school-boy gives me this as a local name for the Germander Speedwell, Veronica Chamcedrys, more commonly called BIRD'S-EYE.

(4) An Evershot school-boy gives it as a local name for the Corn Cockle, Lychnis Githago.

LTTThE BRushes. The Teasel, Dipsacus sylvestris (two Bradford-on-Tone school-girls).

LITTLE CHICKWEED. This is sent me from several districts as a local name for the Pearlwort, Sagina procumbens.

LrTtue Crane's-Bill. Herb Robert, Geranium Robertianum (two Paulton school-girls).

LITTLE DARIING. Mignonette, both wild, Reseda lutea, and cultivated, $R$. odorata. The name "Mignonette" is a French word meaning "little darling."

LITTLE FATR ONE. Common Broom, Cytisus scoparius (a school-girl at Hawkchurch, Devon).

LITTLE Forget-ME-Nots. A Taunton lady gives me this as a local name for the Field Scorpiongrass, Myosotis arvensis.

LITTLE GossIPS. A school-girl at South Petherton gives me this as a local name for "Blue Butchers," i.e., the Early Purple Orchis, $O$. mascula. See also Gossips.

- Little Honeysuckue. Red Clover, Trifolium pratense (Midsomer Norton). For the explanation of this name see HoNExsUCKLE (2).

LITTLE JACK. The Herb Robert, Geranium Robertianum (Hawkchurch, Devon).

LTTTLE JAN. The Herb Robert, as above (Chardstock). 
Little Jane. The Scarlet Pimpernel, Anagallis arvensis (Colyton).

Little Jex. The Herb Robert (Axminster). See Litthe JaN.

Litrle John. Greater Stitchwort, Stellaria Holostea (Tincanton).

LitTle Krock-A-Nidues. Wild Pansy, Viola arvensis (a school-girl at Chewton Mendip).

LitTle Lie-A-BED. Common Groundsel, Senecio vulgaris (a school-girl at Paulto $\Omega$ ). Apparently to distinguish it from the larger flowers of Dandelion and Hawkbit mentioned under LIE-ABED.

Little Open Star. Common Daisy, Bellis perennis (several school-girls at Paulton). See LITTLE STAR.

Little Peep-Bo (or Little Peeper). The Scarlet Pimpernel, Anagallis arvensis (Dowlish Wake). No doubt from the way in which it opens or closes its petals according to the state of the weather, from which it has also earned the popular name of the Poor Man's Weather Gisas or SHEPHERD'S BAROMIETER.

Little Pinks. London Pride, Saxifraga umbrosa (from a school-girl at Chewton Mendip).

Littue Red Riding Hood. (1) The Red Campion, Lychnis dioica (East Mark and Axminster).

(2) Another school-girl at East Mark gives this name as being applied to the Ragged Robin, Lychnis Flos-cuculi.

LITTLE RED RoBin. The Herb Robert, Geranium Robertianum.

LITTLE RoBIN. The Herb Robert, as above (Devon).

Little Rose of Sharox or Little Sharon's Rose. Several school-girls at Paulton give me this as a local name for one of the St. John's Worts, Hypericum. Dr. Watson says the mame would probably be given to any of the St. John's Worts, but usually to the common one, $H$. perforatum.

LitTle Shoe-flower. The Calceolaria (a Bradford-on-Tone school-girl).

LitTlle Star. (1) Common Daisy, Bellis perennis (several school-girls at Oalkhili). Compare LITTLE OPEN STAR.

(2) Lesser Periwinkle, Vinca minor (a schoolgirl at Merriott).

LitTrLe White BeLis. Lily of the Valley, Convalliaria majalis (several school-girls at Paulton). 
LIVE for Ever. A Taunton gentleman gives me this as a local name for the Cudweed, Gnaphalium uliginosum.

LIVE-LONG. A general English name for the Orpine, Sedum Telephium.

Live LoxG AND Love LoxG. A school-girl at Sampford Arundel gives me this as a local name for the Orpine, as above.

Lrvers. (1) The great Yellow Flag, Iris Pseudacorus (Dorset). See Levers.

(2) The Marsh Marigold, Caltha palustris (Rampisham, Dorset).

Loaves of Bread. Common Mallow, Malva sylvestris (East Somerset and North Dorset).

LoB-GRASs. Soft Brome-grass, Bromus hordeaceus (West Somer'set).

LoB-Lolutes. A school-girl at Furley gives me this as a local name for "Love lies Bleeding," Amaranthus caudatus.

Lockets AND Charss. Dicentri spectabilis (West Pennard).

LOCKS AND KEYS. A very common name for the winged seeds of certain trees, particularly

(1) The Ash, Fraxinus excelsior.

(2) The Maple, Acer campestre.

(3) The Sycamore, Acer Pseudo-platamus.

(4) The Lime, Tilia vulguris (Combe St. Nicholas).

(5) The Early Purple Orchis, O. mascula (Bridgwater and Dulverton).

(6) The Wild Hyacinth or Bluebell, Scilla non-scripta (Wiveliscombe, Bradford, and Maunsel).

(7) "Hips," the fruit of the Dog-rose, Rose canina (Stogursey).

(8) Dicentra spectabilis. The Wilts Glossary says this is the usual cottager's name for: this plant throughout Somerset.

(9) The Common Laburnum, Laburnum vulgare (Wimborne).

LOGGERHEADS. Black Knapweed, Centaurea nigra. Dr. Prior says : "From the resemblance of its knobbed involucres to an ancient weapon so called, consisting of a ball of iron at the end of a stick."

LoggerUas. The North Wilts form of Loggerheads, as above.

London BeLls. Hedge Bindweed, Calystegia sepium (Upottery).

London DAISY. Ox-eye Daisy, Chrysanthemum Leucanthemum (Crewker'ne district and Dorset).

London Pretry. London Pride, Saxifraga umbrosa (Leigh, Dorset). 
London PrIDE. (1) The general English name for Saxifraga umbrosa.

(2) In West Somerset the Biting Stonecrop, Sedum acre.

(3) Enchanter's Nightshade, Circau lutetiana (Bridgwater and Taunton district).

(4) Southernwood, Artemisia Abrotonum (Trowbridge district).

(5) Round-leaved Sundew, Drosera rotundi. folia (Childe Okeford).

LoNesone LADY. Bittercress or Cuckooflower, Cardamine pratensis (East Devon).

Long Bears. Shepherd's Needle, Scandix Pecten-Veneris (Leigh, Dorset).

Long-Legs. The Cowslip, Primula veris (school-boys at Aller).

Long Purples. (1) Most commonly the Purple Loosestripe, Lythrum Salicaria.

(2) The Foxglove, Digitalis purpurea (West Somerset).

(3) Early Purple Orchis, O. mascula ('West Somerset and Devon; rarely used). This is believed to be the Long Purples of Shakespeare's Hamlet (iv. 7).

(4) The compilers of the Wilts Glossary state that Tennyson's "Long Purples of the Dale" are the Tufted Vetch, Vicia cracca.

LoNG TAILS. This is given me as a local name for the Watercress, Radicula Nasturtiumaquaticum, at Loigh, Dorset.

LookING-GLAss. Greater Stitchwort, Stellaria Holostea (Hammoon, Dorset).

LooK UP AND KIsS ME. Saxifraga umbrosa (Devon).

(2) The Wild Pansy or IIeartsease, Viola urvensis.

Loppy MAJOR. The Burdock, Arctium minus.

LoRDs AND LADIES. (1) A very general name for the Wild Arum or Cuckoo-pint, Arum maculatum.

(2) Mr. and Mrs. Lansdowne, of Over Stowey, give me this as a local name for Irises.

(3) Early Purple Orchis, O. mascula (Poole).

LovE. Goose-grass, Galium Aparine (Doulting).

Love-A-LI-Do. Wild Pansy, Viola arvensis. (Wilts). See Love IN IDLeness.

Love AND IDoLs. Wild Pansy, as above. Occasionally applied to the garden Pansy also.

Love ENTANGLEd. (1) Yellow Stonecrop, Sedum acre.

(2) The Femnel-flower, Nigella ${ }^{-7}$ amascena, more often called LovE-IN-A-MIST. 


\section{LOVE-GRASS. Eragrostis elegans.}

Love IN A MIST (or IN A PUZzLe). Femmelflower, Nigella damascena; often called DEvII IN A Bush. Dr. R. C. Knight tells me he has heard this plant called LovE IN A MIST when in flower, and DEvIL IN A BUSH when in fruit.

Love IN IDLeness. An old name for the Pansy or Heartsease, Viola arvensis. Mr. James Britten kindly points out that this name does not mean what a present-day reader would naturally take it to mean, but it is equivalent to

"Love in Vain," by which old name the Pansy is still sometimes known. Shakespeare refers to it in lis Midsummer Night's Dream (Act 2, Scene 2):

Yet marked I where the bolt of Cupid fell,

It fell upon a little western flower,

Before milk-white, now purple with love's wound.

And maidens call it Love-in-idleness.

Love IN THE MIDST. Another form of Love IN A MIsT, which see.

Love IN VAIx. The Wild Pansy or Heartsease, Viola arvensis.

Love LIes Bleedrag. (1) The general English name for Amarantus caudatus. Mr. F. 'T'. Elworthy says: "No other plant is known by this name among the peasantry, but some varieties of Celosia are beginning to be so called in gardens."

(2) Frequently applied to Dicentra spectabilis, more often known as the BLEEDING HEART.

(3) In Dorset the name is sometimes given to the Lunary or Money in both Pockets, Lunaria biennis.

Love-MLAx. An old English name for the Goose-grass or Clearers, Galium Aparine, from its habit of elinging to the garments with which it comes into contact.

Love ME, Love ME Not. (1) A Taunton lady gives me this as a local name for the common Daisy, Bellis perennis.

(2) Dr. Watson writes, "The spikelets of the Rye Grass, Lolium perenne, are pulled off whilst saying 'Loves me, loves me not,' and this name is sometimes applied to the plant." See DoEs Mi Mother WANT Me?

LovenIDouds. Mr. Slow gives this form as the Wiltshire name for the Wild Pansy, Viola arvensis; a comuption of LovE IN IDLENESS.

Lovers. Forget-me-nots, Myosotis (a Thorne St. Margaret school-girl).

LOVERS' BCTTON-HOLES. Forget-mutnots, Myosotis (Camerton).

Lovers' Joy. Forget-me-nots, Myosotis (Staple Fitzpaine). 
Lovers' Kisses. Goose-grass or Cleavers, Galium Aparine (Camerton).

Lovers' Kxots. Goose-grass or Cleavers, Galium Aparine (Trowbridge).

Lovers' 'Thodghts. Wild Pansy, Tiola ariensis.

Lovixg ANDREws. Richard Jefferies in his "Village Miners" applies this name to the Mea dow Cranesbill, Geranium pratense.

Loving Idous. The Wild Pausy, Viola arvensis (Tilts). See Love IN IdLexess.

Lovixg Lyoles. Pansies, more especially the smaller varieties (Mr. Edward Vivian, Trowbridge).

LUMPER-SCRUMP OI LUMPERN-SCRUMP. COWparsnip, Heracleum Sphondylium ('Taunton and ivest Somerset).

LUMPRUM Scrump. A Withiel Flory form of the name given above.

LUNGTORT. Great Nullein, Terbascum Thapsus (Stalbridge).

LYre Flower. A name frequently giren to Dicentra spectabilis, known also as the BLEEDING HEART. LADY's LockET, and by many other. popular names.

Lyver. The late G. P. R. Pulman, of Crewkerne, gave this as a local name for the Bulrush, Typha latifolia, and asked: "May this word have anything to do with the origin of 'Liverpool'? 'The arms of that town are a pool with rushes (lyvers) around it." See Levvers (2). Miss Ida M. Roper writes, "Liver is an ima ginary bird, similar to the Phoenix, and as such is used in the arms of Liverpool. The city is more likely named from the Welsh Ller proll, signifying 'place of the pool,' which became in the Midale Ages 'Litherpool '!'

MACE. Mast. Acorns. Beech nuts are called BEECH-MIACE.

MACEYs. Acorns (Wellington distriet).

MACEY-TREe. The Oak (Sampford Arundel).

MADARIx. The Scentless Maymeed, Matricaria inodora (Hammoon, Dorset).

MADDER. Sweet Woodruff, Asperula odorata (N.W. Wilts). Our Wild Madder, Rubia peregrina, is a rclative of the Woodruff, and as a consequence the name may sometimes be given to the latter in error.

MADDER or MADDERS. The Stinking Chamomile, Anthemis Cotula.

MADNeP. Mr. T. W. Cow'un gives me this as a name for the Cow-Parsnip, Heracleum Sphondylium, used by a gardener of his who came from Devonshire. 
Madron. The Corn Feverfew, Chrysanthemum Parthenium (Shaftesbury).

MADWort. (1) Asperugo procumbens, generally known as German Madwort.

(2) Any species of the genus Alyssum. The Rev. H. Friend says: "The Alyssum of the ancients was supposed to have the power of moderating and appeasing anger, and from this it seems to have derived its name. Some have, however, taken the word to indicate that the plant cured hydrophobia and similar raging complaints; on which account we hear of it under the name of Madwort.

(3) Probably sometimes applied in error to the Wild Madder, Rubia peregrina. See CATCHWEED (2).

Maesh. Moss (Wincanton district). See MEsh.

MAIDEN. The Stinking Chamomile, Anthemis Cotula (Dcrsct).

MAIDEN PINK. The general English name for Dianthus deltoides. Dr. Prior says: "A mistake for mead-pink . . a pink that grows in meadows." The plant is very rare in Somerset, and is not found in Dorset or Wilts."

MaIDens' Delight. Southernwood, Artemisia Abrotonum; more often called Boys' Love.

MAmens' Ruin. Southernwood, Artemisia Abrotonum. Sometimes called by the double name "Boys' Love and Maidens' Ruin " (Devon).

MAID IN THE MEADOW. A school-girl at Childe Okeford gives me this as a local name for the Bulbous Crowfoot, Ranunculus bulbosus.

MaID of THE Meadow. The Meadow-sweet, Spirca Ulmaria. More generally called QuEEN OF THE MEADOW.

MaD̃s. The "rose-eved." flower's of the Primrose, Primula vulgaris (Sampford Arundel). See Boys and GirLs.

MAID's HAIR. An old name for the Lady's Bedstraw, Galium verum.

Matsh MaLlow. A corruption of Marsh Mallow, but often applied to the Common Mallow; Malva sylvestris (East Somerset and Wilts). Cf. Mesh MeLuish.

MLATE. Mr. J. C. Mransell-Pleydell gives this as a Dorset name for the Dandeiion, Taraxacum officinale.

MALE LILY. Lily of the Valley, Convallaria majalis (a school-girl at Rodney Stoke). Evidently a corruption of MAY LILY.

Matice or MaLtish. Common Mallow, Malva sylvestris. 
MaLlow-Hock. Common Mallow, Malva sylvestris (Wincanton district).

MALLOW-ROCK. The Houseleek, Sempervivum ectorum (Compton, near Yeovil).

MaNdRake. The Red-berried (or White) Bryony, Bryonia dioica. The fables and superstitions connected with this plant would fill several columns. It was said to shriek when pulled out of the ground.

Man in the PUlpit. Wild Arum or Cuckoopint, Arum maculatum (a school-girl at Otterhampton), more often called PARson IN THE Pulpit.

MaN Orchis. A common name in Somerset for the Twayblade, Listera ovata, probably due to confusion with the true Man Orchis, Aceras anthropophora.

Max's White HAT. A number of schoolchildren at Otterhampton give me this as a local name for the Garden Lily.

MAN-Tie. Common Knot-grass, Polygonum aviculare (Devon and West Somerset, but in the tatter district mcre often called TACKER-GRASs).

MLARE-BLOBS. The Marsh Marigold, Caltha palustris. Dr. Prior gives the derivation as mere $=\mathrm{a}$ marsb, and $b l o b=a$ bladder.

MARE'S TAIL. (1) The general English name for Hippuris vulgaris.

(2) In Vest Somerset, the Comfield Horsetail, Equisetum arvense; more often called in that part of the county OLD MAN's Beard or JoINTWEED.

Margret or marguerite. Ox-eye Daisy, Chrysanthemum Leucanthemum.

Marrajr. The Common Sea-reed, or Matweed, Ammophila arenaria, whose many long roots serve to hold down and to bind together the sand of our dunes.

Marsh Elder. Common Guelder Rose, $V i$ buэnum Opulus.

Marsh Linies. Marsh Marigold, Caltha palustris (Bath district).

Marsh Mallow. Dr. Domnes tells me that the 'Tiee Mallow, Lavatera arborea, is always known by this name about Ilminster, where it is often seen in cottage gardens, the leaves being used for poultices, dc., for bruises.

Marshweed. The Marsh Horsetail, Equisetum palustre. Referred to under this name in Blackmore's "Lorna Doone."

Martha or Marthus. The Coln Chamomile, Anthemis arvensis. 
Mary at the Cottage Gate. Greater Stitchwort, Stellaria Holostea (a school-girl at Oakhill).

MaRY BUds. (1) An old name for the Mari gold, Calendula officinalis. It was probably to this plant that Shakespeare referred when he said :

And winking Mary-buds begin to ope their golden eyes.

(2) Various kinds of Buttercup, Ranunculus.

MARY Goxd. Marigold, Calendula officinalis. Rev. H. Friend says: "This pronunciation and spelling still linger among the common people, and in fact many people of position and intelligence employ it."

MARY JaNes. (1) Red Campion, Lychnis dioica (Thorne St. Margaret).

(2) The Herb Robert, Geranium Robertianum (East Devon).

MARY's Gold. The Marsh Marigold, Caltha palustris.

Mary's 'TEars. A Dorset name for the Common Lungwort, Pulmonaria officinalis.

Mash MaLlice. (1) Marsh Mallow, Althoca officinalis.

(2) Often applied to the Common. Mallow, Malva sylvestris, some authorities say "in error," but Mrr. James Britten tells me that other's maintain the name is correctly given, because this plant was, and still is, used ia making mashes in poultices. See Marsh Maliow.

Mass or Mast. Aeorns.

MATHER, Mathers, or MATHERs. Stinking Chamomile or Mayweed, Anthemis Cotula (Dorset). Mr. T. W. Cowan gives me the following as some of the names applied to this plant in other parts of the country:-Mathes, Maithes, Mavin, Maythig, Mawthen, Mawther, Maise, Meäden, Mayes, and Mothern.

Matherin or Mauthern. Ox-eye Daisy, Chrysanthemum Leucanthemum (Wilts).

MAWL-SCRAWL. A small shrivelled apple (F. T. Elworthy). The word is generally used in West Somerset as a local name for a Caterpillar.

MAY. (1) Hawthorn, Cratogus monogyna.

(2) In Devon more frequently applied to the Lilac, Syringa vulgaris (also Brompton Regis).

(3) In some parts of Devon the Laurustinus, Viburnum T'inus.

(4) Rev. II. Friend also gives Arabis alpina "in Somerset especially." but there is evidently some mistake here, as the plant named is only found in the Island of Skye.

MAY Batis. A common name, in Somerset and Dorset for the Gualder Rose, Viburnum Opulus, particularly for the cultivated double varicty. 
May Blobs. The Marsh Marigold, Caltha palustris. Dr. Watson writes me:-"Since the Marsh Marigold flowers chiefly in April in the South, the references to May suggest northern origins for these names. The plant has usually finished flowering in Somerset before May, except on the moors, which have been under water till late in the spring."

May Blosson. See May (1) and (2).

May Blossons. Lily of the Valley, Convallaria majalis (Devon).

May Bubbles. The Marsh Marigold, Caltha palustris.

May Buds. Buttercup, Ranunculus (Martock).

MAY Flower. (1) Hawthorn, Cratogus monogyna.

(2) The Lilac, Syringa vulgaris (West Somerset and Devon).

MAYFlowers. (1) The Cuckoo-flower, Cardamine pratensis (Sexey's School).

(2) Mar'sh Marigold, Caltha palustris ('Tisbury, Wilts).

May LiLy. The Liiy of the Valley, Convallarin majalis. -

May Pixk. The Common white galden Pink Dianthus caryophyllus.

MAY-PoLE. A school-girl at Gittisham, near Honiton, gives me this as a local name for the Guelder Rose, Viburnum Opulus; more often called MAY-ROSE.

May Rase. The Guelder Rose, Viburnum Opulus.

Max TAssels. The Guelder Rose, as above (Axbridge).

May Tossels. The Guelder Rose, as above (Barrington).

May Tosty. The Guelder Rose, as above (Somerset).

MAYwort. 'The Cross-wort Bedstraw, Galium Cruciata.

Mazenrts. A school-girl at Colyton gives me this as a local name for the Wild Cherry, Prunus avium. See MAZzARD.

MazZard. The Wild Cherry, Prunus avium; also a kind of black cherry extensively cultivated in North Devon. Mre. Elworthy says : It is a common saying that to gather them you must hold on with your nose and pick with both hands. Hence the usual remark upon a hooked nose 'He've agot a nose fit for a MAZZARD-PICKER.' '

MeAdex. Stinking Chamomile, Anthemis Cotula (Dorset). See MATHER. 
Meadow Parsitip. Cow Parsnip, Heracleum Sphondylium.

MEadow Pink. (1) Ragged Robin, Lychnis Flos-cuculi (Martock and Shute, Devon).

(2) Cuckoo-flower, Cardamine pratensis (Stockland, Devon).

MEADwort. The Meadow-swset, Spircea Ulmaria.

MEASLE-FLOWER. The garden Marigold, Calendula officinalis, dried flowers of which have some reputation in Wilts as a remedy. Children, however, have an idea that they may catch the complaint from handting the plant.

Meatndt.- "Chestnuts are also called Meatnuts, because they are used for food " (Rev. H. Friend, Devon).

MeEt Her (or ME) IN THE Entry. An old name for the Wild Pansy or Heartsease, Viola arvensis.

MeEt Me Love. In North Devon this name is given to the London Pride, Saxifraga umbrosa, as a contraction of "Meet me, Love, behind the garden door" ; but the name is usually applied elsewhere to the Pansy.

Mex Axd Women. Wild Arum or Cuckoopint, Arum maculatiom (Sexey's School).

MEN of War. The Ribwort Plantain, Plantago lanceolata (Durston). See Cock's Heads and SOLDIERS.

Men's FACES. The Pansy, Viola tricolor (Evercreech).

Merrx. The Wild Cherry, Prunus avium.

Merry-goes. A school-girl at Membury (Devon) gives me this as a local name for the Periwinkle, Vinca. Mr. Jas. Britten suggests that this may be a corruption of Marigold, applied to the Periwinkle in error.

MERRY-Go-Rodnds. A Sherborne lady gives me this as a local name for the Marigold, Calendula officinalis.

MaSH (from A.S. $m e o s=$ moss). (1) Moss.

(2) Lichens, Usnea, Ramalina, and Evernia, which grow plentifully on apple trees.

Mesh-Meluish. Rev. H. Friend gives this as a Devonshire pronunciation of Marsh Mallow, Althoea officinalis. Cf. MAISH MaLLOW.

MESLIN or MEsLIN-CORN. A mixture of wheat, barley, and oats-often sown upon odd corners for poultry or game (F. T. Elworthy). From the Latin miscellanea. "Take thee, therefore, all kinds of grain, wheat, and barley, and beans, and lentiles, and fitches, and put them all together, and make bread of this mestine." $B p$. Hall: Hard Texts ; Ezekiel iv., 9. 
Mess-ABed. The Dandelion, Taraxacum officinale. Dr. Downes writes :- "A curious superstition prevails in western countries, even into Cornwall, that children who pick Dandelions will 'wet their beds.' This is no doubt connected with the old herbalists' view that the root 'makes an excellent decoction to promote urine.'" See PISS-ABED.

Mews. Mross. Mr. Elworthy tells us "Whitdroats' nestes bain't never a builded way MEws ; they always be a-builded way motes o' hay like. Cuddlies now d'always make theirs way Mews."

Mezard. Wild Cherry, Prumus avium (Cirardstock). See MAZzard.

Mice's Mouths. The Yellow Toadflax, Linaria vulgaris (S.W. Wilts).

Mrchaelaras Crocus. Meadow Safinon, Colchicum autumnale.

Michaelaras Daisy. (1) The general English name for the cultivated Aster Tradescanti and other species of Aster.

(2) The Sea Aster or Starwort, Aster Tripolium; common in mud-banks along the coast and the salt marshes of Somerset.

(3) The name is erroneously applied to other flowers as well, at an earlier season of the year, including the Feverfew, Chrysanthemum Parthenium. See Midsomarer Daist (2).

MIDDLE CoMfrey. An old country name for the Bugle, Ajuga reptans.

Minsunner Datsy. (1) The Ox-eye Daisy, Chrysanthemum Leucanthemum.

(2) The Feverfew, Chrysanthemum Parthenium, in flower at this time of the year, but sometimes called Michaelamas Datsy through eonfusion.

MIDSUMaIER FAIR-matD. A lady at Compton (near Yeovil) gives me this as a local name for the Thrift, Statice maritima.

Minsumner LiLY. The White Lily, Lilium candidum (Mr. W. C. Baker).

Mmsunmer Max. A lady at Chilmark (Wilts). gives me this as a local name for the Broom-rape, Orobanche.

Midisumaner Mex. (1) The Orpine or Livelong, Sedum Telephium, from an ancient custom of girls to try their lovers' fidelity with it on Midsummer-eve, as described in Brand's Popular Antiquities. Hannah More relates of a young country girl, that she would never go to. bed on Midsummer-eve without putting up in her room a piece of the plant called Midsummermen, as the bending of the leaves to the right or to the left would indicate the constancy or faithlessness of the object of her thoughts. 
(2) In Wilts the name is given to a variety of the Red Orpine, Sedum Fabaria. Dr. Watson writes:-Sedum Telephium and $S$. Fabaria are critical species only distinguished by botanists (and there are differences of opinion even amongst them). They both usually have purple flowers. The Red Orpine is merely the plant with the usual coloured petals. The name is doubtless given indiscriminately to Sedum. Telephium and $S$. Fabaria in both counties.

(3) A correspondent near Martock gives it as a local name for the Red Spur Valerian, Kentranthus ruber.

MIGWoRT. Common Wormwood or Mugwort, Artemisic vulgaris (Hammoon, Dorset).

MmK Cans. Greater Stitehwort, Stellaria Holostea (Trowbridge).

MHK-FLOWER. Evening Campion, Lychnis alba (Charlton All Saints, Wilts).

MrLkIEs. Cuckoo-flower, Cardamine pratensis (Exmouth).

Mirkivg MatDs. Cuckoo-flower, as above (Brompton Regis).

MIIK-MraIDS. A name applied to a number of different flowar: but most generally throughout this district to

(1) The Cuckoo-flower or Lady's Smock, Cardamine pratensis.

(2) Greater Stitchwort, Stellaria Holostea.

(3) The Wood Anemone, Anemone nemorosa.

(4) The White Campion, Lychnis alba.

(5) Several correspondents give this as a local name (Dorset) for Meadow Saxifrage, Saxifraga granulata. Mr. W. C. Baker applies the name to Saxifraga media, which is a native of the Pyrenees, sometimes grown in English gardens.

(6) A lady at Colyton gives it as a local name for the Milkwort, Polygala vulgaris.

MIKK STochs. Flowers of the Box, Buxus sempervirens (Plush, Dorset).

M\#K THIstLE. (1) The general English name for Silybum Marianum; rare in Somerset.

(2) Very commonly applied to the Sow Thistle, Sonchus oleraceus.

MrLK WEED. Common Sow 'Thistle, Sonchus oleraceus (West Somerset).

Мшк WORT. (1) Various species of spurge, particularly the Sun Spurge, Euphorbia Helioscopia, and the Petty Spurge, E. Peplus.

(2) The Sow Thistle, Sonchus oleraceus (Miss Ella Ford, Melplash).

MnKy DASHel. Common Sow Thistle, Sonchus oleraceus (West Somerset and Devon). Also the Sharp Fringed Sow Thistle, S. asper, both species being common and not usually. distinguished except by botanists. 
Muкy Dicel. Sow 'Thistle, as above (Stogursey).

Mukx Dishe. Dandelion, T'araxacum officinale (Rer. H. Friend, Devon).

i MIIKXMatos. Cuckoo-flower, Cardamine pratensis (Devon).

MIHLER'S DELIGHT. A correspondent at Cerne Abbas gives me this as a local name for the Corn Blue-bottle, Centaurea Cyanus.

MULLE's STAR. Greater Stitchwort, Stellaria Holostea (two school-girls at Queen Camel).

Mrut Mountary. Ground (or Purging) Flax, Linum catharticum.

Mind Your OwN Business. This appear's to be the usual name in the Yeovil and Mudford district for a small spreading plant which Dr. Watson tells me is Helxine Solierolii. He knows no common English name for the plant, but has heard it called Artillery-plant in mistake for the true Artillery-plant, Pilea. A gardener living near Yeovil told me he knew the plant only by the name of OLIVER CROMWELI'S CreEPING Companion. Mr. W. D. Miller describes it as an intolerable weed.

Mrschievous JaCK. Common Chickweed, Stelalria media (Ilton).

Miss Modesty. (1) Common Daisy, Bellis perennis (a Yeovil school-boy).

(2) The Violet, Viola odorata (a school-girl at Shaftesbury).

MISs Scenty. The Violet, as above (a schoolboy at Everereech).

Mock. A tuft of grass. Mr. Elworthy says. "In pasture land the cattle usually leave tufts or patches of the ranker herbage; these are always called Mocks." Rev. Wm. Barnes (Dorset) defines it as " a tuft of sedge or a root or stump of a cut-off bush." Mr. F. IV. Mathews writes : "In soggy commons one steps from tussock to tussock of grass; these are always named Mocks."

Mock OrangE. The general English name of Philadelphus coronarius, a plant with large creamy white flowers, with a powerful odour, somewhat resembling that of Orange-blossoms, cultivated in shrubberies and cottage gardens., Very genorally called Syringa.

Modest MaIDEN. The Violet, Viola odorata (two Ilminster school-girls).

MogruRd. The usual name in West Somersef for the Common Mugwort, Artemisia vulgaris.

Mol. O' THE Woods. Wood Anemone Anemone nemorosa (Fiddleford, Dorset). 
Moly. Correspondents at Compton (near Yeovil) and Stockland (Devon) give me this as i local name for the Wild Garlic or Ramsons, Allium ursinum. The common nam in some parts for Allium Moly.

Dr. Prior says MoLy is the name of a plant in Homer's Odyssey, and occasionally introduced into modern poetry as in Milton's Comus. p. 636, but not identified with any known species; the Encyelopædic Dictionary, however, states Homer's MoLY is Allium magicum.

Moner. (1) Yellow Rattle, Rhinanthus Crista-galli (Shoscombe).

(2) Honesty, Lunaria biennis (West Somerset and East Devon).

Money Bags. Common Shepherd's Purse. Capsella Bursa-pastoris, of which Anne Pratt says: "Its numerous flat seed-pouches characterise the plant; and they are sufficiently like a rustic flat leather purse to have obtained for it not only its English name, but the synonyms by which it is known in country places almost throughout Europe." The mediaeval purse, which hung from the girdle, was shaped just like the fruit of this plant.

MONEY Box. Two school-girls at Horton give me this as a local name for the Figwort, Scrophularia.

Money Frower. Honesty, Lunaria biennis

MIONEy IN Both Pockets. (1) A very general name for Honesty or Lunary, Lunaria biennis, from the transparent, purse-like seedpods, which contain the seed on both sides of a dividing membrane.

(2) Several correspondents in both Somerset and Dorset give this as a local name for Phlox,

(3) Seeds of the Maple, Acer campestre (Curry Mallet).

(4) Common Agrimony, Agrimonia Eupatoria (Leigh, Dorset).

Money in Every Pocket. Honesty. More gencrally called MoNex in Both Pockets.

Money Plant. (1) Flonesty, as above; particularly in Devon.

(2) Penny Cress, Thlapsi arvense. This plant owes its general English name to the fact that its seed vessels are about the size of the old English silver pennies; when these coins were in common use the name was expressive, but it is scarcely understood now. Doubtless the name MoNEY Plant, which is sent me from Durston and other places, is due to the same reason. See MONEY TREE.

MoNey Pockets. Honesty or Lunary, Lunaria biennis (Ilminster district).

MONEY TREE. A school-girl at Widworthy 
(near Honiton) gives me this as a local name for the Penny Cress. See Money Plant (2).

MONEY WORT. A very general name for the Creeping Loosestrife, Lysimachia Nummularia

Monkey BelLs. A school-girl at South Petherton gives me this as a local name for the Marsh Marigold, Caltha palustris.

MoNkey Chops. (1) Snapdragon, Antirrhinum majus (Mid. and Edst Somerset).

(2) Two Evercreech school-boys give mo this as a local name for the Ground Ivy, Nepeta hederacea.

(3) Fiom Everelech also I have the name as being applied to the "Musk," by which is piobab.y meant Mimulus Langsdorffii, but possibiy H. moschatus.

MoNkey Cups. "Wild Musk," Mimulus Langsdorffii (Laigh, Dorset).

Monkey Faces. (1) Garden Pansy, Viola tricolor.

(2) Yellow Toadflax, Linaria vulgaris (Miiborne Port).

(3) Tne Snapdragon, Antirrhinum majus (Westbury, Wiits).

MIonkey Flower. (1) A very general name for various species of Mimulus, and particularly for the handsome Yellow Mimulus Langsdorffii, which is now found in many of our streams and diiches, but is a comparatively recent ar'ival from North America.

(2) The Snapdragon, Antirrhinum majus (Shepton Mallet and Oakhill).

(3) Ground Ivy, Nepeta hederacea (Stoleunder-Ham).

Monkey JAcks. Same as Monkey Flower (1) (Beaminster).

Monkey JAws. Ivy-leaved Toad-flax, Linaric Cymbalaria (Stratton-on-the-Fosse).

MoNkey Mouths. (1) The Snapdragon, Antirrhinum majus.

(2) Ivy-leaved Toad-flax, Linaria Cymbalaria (High Ham).

Monkex Musk. (1) Same as Monkey FLOWER.

(2) The Wilts Glossary says: "The large garden varieties of Himulus, which resemble the true Musk, but are scentless, and therefore merely Honkey (i.e. mock, spurious) musk" (N.W. Wilts). Dr. Watson points out that this suggested derivation is an error. The namo Mimulus means "little ape," and refers to the shape of the corolla.

(3) Rev. H. Friend gives it as a Devonshire name for the Snapdragon, Antirrhinum majus, and $I$ also have the name in this connection from a school-girl at Oakhill. 
Monkey Noses. The Snapdragon, Antirrhinum majus (Chideock, Dorset).

Monkey Nut. Meadow Grass, Poa annua, eaten by boys for its nut-like flavour (S.W. Wilts).

Monkey Plant. (1) Same as Monkey FLOWER.

(2) The garden Mimulus (Wilts Glossary).

(3) Yellow Rattle, Rhinanthus Crista-galli (Dorset).

Monkey PuzzLe. A very general name for the Cailian Pine, Araucaria imbricata. The tree is often grown in shrubberies and gardens, and owes its popular name to the fact that its crowded and twisted branches make it practically impossible for a monkey to climb them.

Monkey's Hood. The Monks-hood, Aconitum Napellus, is sometimes so-called in Devon, and it has been suggested that this is due to the retention of the old possessive "Monkeshood."

Monkey STICKs. Two school-girls at Oakhill give me this as a local name for the Snapdragon, Antirrhinum majus.

Monkey Tree. (1) Sam3 as Monkey PuZzLE.

(2) The Sumach, Rhus (Harnham, Wilts).

(3) II: Edward Vivian (Trowbridge) tells me that in that district the name is frequently given to several species of Cactus, or any prickly foreign tree.

Monk's Head. The Dandelion, Taraxacum officinale (Taunton and Trowbridge).

MONK's RHUBARB. A general English name for the Alpine Dock, Rumex alpinus. See GARDEN Patience.

Movivies. Ox-eye Daisy, Chrysanthemum Leucanthemum (Stoguisey).

Monthly Rose. A general name for any one of the many varieties of China Rose which bloom continuously throughout the season. Rev. H. Friend gives it as being applied in Devon more particularly to Rosa indica.

Moocher. The fruit of the Blackberry, Rubus fruticosus (Wilts).

Moon DAISY. A very general name throughout the district for the Ox-eye Daisy, Chrysanthemum Leucanthemum.

MOoN-FLower. (1) Mr. and Mrs. Lansdowne, of Over Stowey, give me this as a local name for the Hawthorn, Cratcogus monogyna.

(2) Honesty or Lunary, Lunaria biennis (Beaminster). See MooN-Wort.

(3) Same as Moon-DAISx (a Dunster schoolgirl). 
Moon's ExE. Ox-eye Daisy, Chrysanthemum Leucanthemum (a Minehead school-girl).

Moon-wort. (1) The general English name for the Fern, Botrychium Limaria.

(2) Honesty, Lunaria biennis. See MoorFLOWER (2).

Moor. The several branching roots and rootlets of a tree which grow out from the MоOT. Mr. Elworthy quotes one as saying "We've a chopped off the Moons, but we shant never beat thick there Moot abroad 'thout we puts a bit o' powder in un." See MorE.

Моот. The entire root of a tree, including all Moors or branching rootlets. When a tree is felled all that remains in the ground is called the Mоoт.

Mop. A tuft of grass (Rev. W. P. Williams).

Mops. A Thorncombe correspondent gives me this as a Devonshire name for the Greater Knapweed, Centaurea Scabiosa.

MoRE. The root of a flower or of a small plant; a single root of a tree (Rev. Wm. Barnes). Dr. Downes writes "MIOREs is a general term for roots in the West of England, eren roots of a tooth!" See Moor.

MorNing GLoRY. (1) Hedge Convolvulus or Bindweed, Calystegia sepium.

(2) Field Convolvulus or Lesser Bindweed, Convolvulus arvensis (much less frequently).

(3) A very general name for the cultivated climbing Convoivulus, Ipomoca purpurea.

Morning Stars. (1) Several young people at Dunster and others at Cutcombe and Hatch Beauchamp give me this as a local name for Chrysanthemums.

(2) A school-girl at Ilminster gives me this as a local name for the Snowdrop, Galanthus nivalis. Dr. Downes suggests probably in confusion with the Star of Bethlehem, Ornithogalum.

(3) Greater Stitchwort, Stellaria Holostea (Shaftesbury).

Moses' BLanketr. Great Mullein, Verbascum. Thapsus (Ubley).

Moses IN THE Bulrushes. (1) Several school-boys at Evercreech give me this as a local name for the Arrowhead, Sagittaria sagittifolia.

(2) His Honour J. S. Udal gives this as a Dorset name for the Spiderwort, Tradescantia. virginica.

(3) A Dorset lady tells me this is a Dorset name for a kind of Iris.

Moss Roses. A school-girl at Doulting gives me this as a local name for the Scarlet Elf-cup Fungus, Geopyxis coccinea, often rowing on mossy twigs. See ELF-CUP. 
Mote. A single Straw or single stalk of Hay.

Mother Carey's ChICKen. A lady living near Taunton gives me this as a local name for the Double Daisy. See Hen and Chickens (2).

MIother DAIsy. As a boy in East Somerset I seldom or never heard the Ox-eye Daisy, Chrysanthemum Leucanthemum, called by any other name than this.

Mother DIE. A Bridgwater school-mistres gives me this as a local name for the "Wild Parsley" (?) ; known also by the school-children in that district as PICKPOCKET.

Mother Mary's Mirk. A Martock lady gives me this as a local name for the Common Milkwort, Polygala vulgaris.

Mother of MrLlions. The Ivy-leaved Toadflax, Linaria Cymbalaria. See below.

Mother of Thousands. (1) The Ivy-leaved Toadflax. See above.

(2) Yellow Corydalis, Corydalis lutea. The Rev. H. Friend gives this as a Somerset name, and it is sent me from Bradford-on-Tone and other places.

(3) Mr. F. T. Eiworthy gives this as a West Somerset name for the "Creeping Campanula" (?), and a correspondent at Hatch Beauchamp, gives it as a local name for the "Campanula." Dr. Watson writes we that Mr. Elworthy's Campanula is not a British species, but is a potplant often grown in company with Saxifraga sarmentosa (6), and the name MIOTHER OF 'THOUSANDS, which is usually given to the latter, has been applied to the former through confusion. Mr. W. D. Miller suggests that Mir. Elworthy's plant is Wahlenbergia hederacea.

(4) Two school-girls at Stower Provost (Dorset) give it as a local name for the Common Yarrow or Milfoil, Achillea Millefolium.

(5) The Virginian Stock, Malcolmia maritima (Wiits and Dorset).

(6) The rambling pot plant, Saxifraga sarmentosa; known also as SPIDER-PLANT, STRAWBerry Plant, Aaron's Beard, Poor MAN's Geranium, \&e.

(7) Mr. Edward Vivian (Trowbridge) gives it as one of several local names for London Pride, Saxifraga umbrosa.

Mother Shimbles' SNIck Needles. Greater Stitchwort, Stellaria Holostea, a name recorded in the Sarum Diocesan Gazette as used at Zeals.

Mother's Night-CAPS. Greater Convolvulus, Calystegia sepium (a school-girl at Stockland, Devon).

Mother Thread My Needle. Herb Robert. Geranium Robertianum (Ditcheat). 
MIOTHER THYME. Wild Thyme, Thymus Serpyllum. One of the old English names for this plant was "Mother of Thyme."

Motherwort. (1) The usual English name for Leonurus Cardiaca, which is, however, rare in Somerset.

(2) Correspondents at Stoke St. Gregory and Rodney Stoke give me this as a local name for "Wild Arrach," by which I presume they mean the Wild Orache, Atriplex patula.

Moth Plant. A Taunton lady gives me this as a local name for the Great Mullein, Verbascum Thapsus.

Mountain Ash. The general English name for Pyrus Aucuparia. Mr. Elworthy says : "Very common tree in the district, thus called by the people of the better class. Among the labouring class it is always QuICK-BEAm." Mr. W. S. Price tells me it is also called Bug-BEAM in West Somer'set.

Mountain Mint. Common Calamint, Calamintha montana.

Mountain Mist. A school-girl at Axbridge gives me this as a local name for Heather, Calluna vulgaris.

Mountebanks. A Taunton correspondent writing in our "Notes and Queries" columns in 1902 gave this name and JoHnny Mountains, as the two names by which he had most frequently heard Fircones called in Taunton and other parts of Somerset. See DoLly Mounter and Johnny Mountain.

Mournful Bell of Sodom. A lady at Martock gives me this as a local name for the Fritillary or Snake Lily, Fritillaria Meleagris. See DroopING BELL OF SODOM.

Mournful Widow. A fairly general name throughout the district for the Field Scabious, Scabiosa arvensis. Also the garden variety, Scabiosa atropurpurea.

Mourning Bride. A lady at Damerham (Wilts) gives me this as a local name for the Seabious, Scabiosa arvensis. See Mournful Widow.

Mourning Widow. (1) His Honour J. S. Udal gives this as a Dorset form of the above name for the cultivated Scabious, Scabiosa atropurpurea.

(2) A lady at East Grimstead (Wilts) gives me this as a local name for the Meadow Crane'sbill, Geranium pratense, but Mr. James Britten tells me the plant to which the name is usually given is the Dusky Crane's-bill, G. phoum. This, however, is very rare as a wild plant, and when found wild it is almost invariably an escape from some garden. 
Mouse-Ear. (1) The old English name of the Myosotis, ncw known as the FORGET-IIE-NOT. The latter name was not applied to this plant until 90 or 100 years ago. The name ForgeTME-NOT Was previously given to the little Blue Speedwall (now known as BIRD's-Exes, and to the Ground Pine, Ajuga Chamcepitys, because of its unpleasant taste which was long-enduring. Mouse-EAR is an exact translation of the Greek Myosotis, which was given to the plant 1,850 years ago by Dioscorides, and which it still bears as its botanical name.

(2) Several species of Chickweed, the genus Cerastium, are genetally known by the name of MOUSE-EAR CHICKIVEED.

(3) The Common Mouse-ear Hawkwaed, Hieracium Pilosella.

Mousen-WITHY. A kind of willow, which grows in hedges or dry places. It makes capital binds from its toughness, and is much sought after by thatchers (F. T. Elworthy). Mr. F. W. Mrathews tells $m$ o the rind is grey mouse colour.

Mouse's Ears. (1) Same as Mouse-EAr (1).

(2) The wnite-leaved garden variety of Stachys lanata. See DoNkEX's EAR (1).

Mouse-TAIL. (1) The general English name of Myosurus minimus. The generic name derived from the Greek, means "mouse-tail," and the plant is known by an equivale.t name in many of the countries of Europe.

(2) Various species of Plantain, Plantago (Yeovil and South Somerset).

(3) In som? places the Biting Stoncerop, Sedum acre is knowa by this name.

Mowing DAIsy. Ox-eye Daisy, Chrysanthemum Leucanthemum (Sexey's School and Queen Camel).

Mugaet-Rose or Muggets. The Guelder Rose, Viburnum Opulus (Somerset and East Devon), Mr. W.S Price tells me that the latter form is the general name for the Guelder Rose in West Siomorset.

Mugs Without Handles. An Evarereech school-boy gives me this as a local name for the Canterbury B sll, Campanula media.

Mugwort. The general English name for Artemisia vulgaris, and sometimes given to $A$. abrotonum, commonly known as BOY'S-LOVE.

Muss. A common contraction for "Ch"ysanthemums."

MUnCorn. Various kinds of grain sown together. See MesLIN.

MUsheroon. Mushroom. Always pronounced as three syllables, with the final " $n$ " distinct, proving how much more conservative of imported 
words the dialcet is than the literaxy language. Ond French mowscheron. Mr. T. W. Cow:en tells me " IIusheron" recur's in Palsgiave, 1530.

Mústard Tips. A Yeovil school-boy gitve me this as a local name for the Black Medick, Medicago lupulina, or the Hop Trefoil, Trifolium procumbens. It is probable that the nams is appiled to both plants.

MutToN CHops. The young tops or shoots of the Goosefoot, Chenopodium, sometimes boiled in the spring for food ( $\mathrm{R} v$. W. Barnes, Dorset).

Mutton Dock. Mercury Goosefoot or Guod King Henry, Chenopodium Bonus-Henricus (Bourton, Dorset).

Mutron Tops. White Goosefoot, Chenopodium album (Allerford and Dorset). See MUTToN Chops.

Mr LADY's EAR-DRops. The Fucbsia (South Petherton). Sзe EAR-DRops and LADY's EARDROPS.

Mr LADY's GRass. Striped Ribbon Giass, Pholaris arundinacea form variegata.

MY LADY's LACE. Miss Ida Roper gives me this as a Dorset name for the Cnervil, formerly known to botanists ais Charnphyll:m syluestre, but now as Anthriscus sylvestris.

Mr LAdr's Swock. A lady at Lyme liagis gives me this as a local name for the Cuckooflower, Cardamine pratensis ; more generally called LADY'S SHOCK.

NaIns. Common Daisy, Bellis perennis (Mete. Wilts).

Namwort. An o'd Eng!ish nam for Whitlow-grass, Erophila. Anme Piatt says : "Tne nam? of Wnitlow-grass, as woll as that of Nailwort, points to the opinion of our old herbalists, that the acrid juice of these plants, mingled with milk, cured whitlows; though, probably, the efficacy of the rem dy belonged to the milk only, hot milk being still used in cases of whitlow."

NAKed (or NAKey) Boys. (1) Meadow Saffron or Autumn Crocus, Colchicum autumnale.

(2) A correspondent at Dorchester gives me this as a local name for the "Water Anemone" by which Dr. Watson tells we is almost certinly meant Ranunculis fuitans, a large-flivered Water Crowfoot, which is plentiful in the Dorchester streains.

NAKED JACKs. Autumn Crocus, as above (1).

NAKED LADIES. (1) One of the commonest names for the Meadow Saffron or Autumn Crocus, Colchicum autumnale, due to the flowers springing up on long slender stems, with an apparently 
entire absence of leaves.

(2) The Cuckoo-flower, Cardamine pratensis Over Stowey).

NAKED MAIDEN. Two Ilminster school-girls give me this as a local name for the Snowdrop, Galanthus nivalis.

NAKED MEN. A Dorset form of the name NAKED LADIES (1).

NAKed NAnnies. Several young people at Oakhill give me this as a local name for the Early Purple Orchis, Orchis mascula.

NAKed NANny. The autumn Crocus. See NAKed LAdies (S. W. Wilts).

NANCY. (1) Greater Stitchwort, Stellaria Holostea (East Somerset).

(2) The Wood Anemone, Anemone nemorosa (Sherborne).

NANCy PRetTy. (1) Probably a corruption of "None so pretty." Virginian Stock, Malcolmia maritima.

(2) In Dorset and Devon, London Pride, Saxifraga umbrosa. Mr. T. W. Cowan tells me this name is also used in Scotland and in East Yo:kshire.

Nanny Goats' Mouths. Ivy-leaved Toadflax, Linaria Cymbalaria (Shute, Devon).

NAsty Urchins. A school-children's play upon the nam? Nasturtium; sent me from Dunster and other places.

Nation Grass. A name given on the Somerset border of S.W. Wilts to the Tufted Hair-grass, Deschampsia caspitosa; probably an abbreviation of CARNATION-GRASS, which see (3).

NaUghty MaN's Cherries. The poisonous fruits of the Deadly Nightshade, Atropa Belladonna. See Devir's Cherries.

Naughty Max's Play-thing. The Common Stinging Nettle, Urtica dioica. Called also Devil's Play-thing.

Navel-Wort. (1) The Wall Pennywort, Cotyledon Umbilicus-Veneris.

(2) Mr. Edward Vivian (Trowbridge) tells me this name is also given to the Hound's-tongue, Cynoglossum officinale.

NECK-WweEd. A cant name for the Hemp, Cannabis sativa, as furnishing halters for the gibbet. See GALLOW-GRASS.

Needle Cases. A correspondent at Hammoon (Dorset) gives me this as a local name for the Comfrey, Symphytum officinale.

Teedle Chervil. Miss Audrey Vivian (Trowbridge) gives me this as a common local name for the Shepherd's Nerdle, Scandix PectenVeneris. 
Needef Furze or Whtx. Petty-Whin, Genista anglica

Needle Greenweed (or Greenwood). Pettywhin, as above.

Needles axd Prss. (1) Common Furze, Olex europaus (a school-girl at Oakbill).

(2) Wild Pansy or Heartsease, Viola arvensis (Leigh, Dor'set).

Nelson's Bugle. A school-girl at Edst Harptree gives me this as a local name for the Common Bugle, Ajuga reptans.

Nenniry or Nenewry. A very frequent form of the name Anemone.

Nep. Cat-mint, Nepeta Cataria. Sec CAt-Nep.

Newr-Mown HaY. (1) Sweet Woodruff, Asperula odorata (Thurlbear and Stoke St. Mary).

(2) Meadon Sweet, Spircea Ulmaria (Shepton II:Uite-1).

(3) Yellow Rattle, Rhinanthus Crista-galli (a Crewkerne school-girl).

Dr. Watson tells me this term is also applied to a number of otber plants, and be advised the omission of the three examples I have given.

New Year's GrFt. Winter Aconite, Eranthis hyemalis.

Nigger-Heads. Black Knapweed, Centaurea nigra (Forton).

Niggers. Hoary Plantain or Lamb's Tongue, Plantago media (TVellow).

Nigger's Heads. Hoary Plantain, Plantago media (Alfington, Devon).

Night Bonnets. Red-berried Biyony, Bryonia dioica (Miss Ella Ford, Melplash).

Night CAps. (1) Greater Bindiveed, Calystegia sepium.

(2) The Columbine, Aquilegia vulgaris. See GRANNT'S NIGHTCAP (1).

Nightingale. Greater Stitchwort, Stellaria Holostea (S.W. Wiits, Hants Border).

Night-SHADE. A correspondent at Broadwinsor gives me this as a local name for the Periwinkle, Vinca. Dr. Watson think this is an error due to confusion.

NighT-SHIRTs. Greater Convolvulus, Calystegia sepium (Yeovil and Ilminster).

Night VIOLET. Butterfly Orchis, Habenaria virescens (N.W. Wilts; Sarum Diocesan Gazette).

NindBle TaILor. A well-known and prolific variety of field-pea (F. T. Eiworthy).

Nip. Catmint; see NeP.

NIPPER-NUT. A school-girl at Sampford Arundel gives me this as a local name for the Tuberous 
Pea, Lathyrus montanus, the nut-like tuberous roots of which dre nutritious and palatable, and are often eaten by children.

Nit Clickers. Several young people at Mells give me this as a local name for the Greater Convolvulus, Calystegia sepium.

Nits. Greater Stitchwort, Stellaria Holostea (Leigh-on-Mendip).

NoAH'S ARK. (1) In this district most generally applied to the Monk's-hood, Aconitum Napellus.

Other correspondents apply the name to

(2) Various species of Campanula (Camerton).

(3) The Lupin, Lupinus (Hatch Beauchamp).

(4) The Lirkspur, Delphinium (Chetnoie, Dorset).

(5) The Columbine, Aquilegia vulgaris (Winfrith).

Nobodr's FLower. A correspondent at S3lisbur y gives me this as a local nam? for the Marigold, Calendula officinalis.

Nobs (or KNobs). Apples (Thorne St. Margarct' and Sampford Arundel).

None So Pretry. (1) Virginian Stock, Malcolmia maritima.

(2) London Pride, Saxifraga umbrosa.

Nonesuch. The cultivated Scarlet Ly Lychnis chalcedonica. See FLowER OF BRISTOWE.

Nox-Such. (1) A general name for Black Medick, Medicago lupulina. Mr. F. T. Eiworthy said: "A kind of green fodder, but I am unable to identify it slearly. I have heard 'Lucerne' (Medicago sativa) so named, but Prior gives Hedicago lupulina, and Britten accepts his authority."

(2) Also a variety of table apple.

Noon Peepers. A correspondent at Breamore (Wilts) gives me this as a local name for the Star of Bethlebem, Ornithogalum umbellatum. See I'welve O'ClOCKS.

NooN-TIDE. Yellow Goat's-beard, Tragopogon pratense (Brompton Regis and Evershot). More oftea called JACK (or JOHN)-GO-TO-BED-AT-NooN.

Nose-BleEd (1). Common Yarrow or Milfoil, Achillea Millefolium, so called because "the leaucs bring put into the nose do cause it to blecde " (Gerarde, Herball, p.915).

(2) A correspondent at Thorncombe gives it as a local name for the Hemlock, Conium maculatum.

Nose-SMLART. The Nasturtium (Compton, near Yeovil).

Nose-TICELER. The Nasturtium (Stratton-onthe-Fosse). 
Nose-Twitcher. The Nasturtium (Dorset).

NUFFin-IDols. A N.W. Wilts orruption of Love-In-IdLeness; the Wild Pansy, Viola arvensis.

Numper Nelu. Mr. Edward Vivian (Trowbridge) gives me this as a local name for an oldfashioned, if not obsolete, variety of apple, growing to a large size.

Numpinole. The Scarlet Pimpernel, Anagallis arvensis (N.W. Wilts). Mir. C. T. Onions wites "No doubt due to progressive corruption of Pimpernel, through some form lik pimpernoul, which is apparently of Yorkshire form."

Nun of the Frelds. This is the French name for is white variety of the Harebell, Campanula rotundifolia. It has been sent me by several correspondent as a local name for the Harebell, without reference to colour, but if the name is used in this distrist at all I imagixe it has been taken from the French.

Nutmeg Grater. A Martock lady gives me this as a local name for a variety of the scented Greranium.

OAK. The Rev. Hilderic Friend says he has been ast onished to find how frequently the Maple, Acer campestre, is called "Oak" in Devonshire. Mi. T. W. Cowan tells me that Dog OAK is' a common name for Acer campestre, which I find is also called "Oak" in West Somerset.

OAK-FERN. This is the genral English nam for Phegopteris Dryopteris, but in mary parts of Somerset it is applied to the common Bracken, Pleris aquilina, for the reason that if the stalk is cut across noar the root there are dark markings on the section, which strongly resemble a very symmetrical oak tree.

OAK MaceYs. Aco:n (Wellington district).

OAK NUTS. Acorns (Draycott).

OAKY-Marbles. Dry gall-nuts of oak, frequently used by children as substitutes for stone marbles.

OAT-GRASS. Narrow-leaved perennial Oat, Avena pratensis (West Somerset). This local name for this grass is given by the $R=v$. R. P. Murray, and has been sent me by several correspondents in West Somerset, but Dr. Watson writes me that he has never seen Avena pratensis in that part of the county, and there is only one record fo" it, and even that is a doubtful ons. He says Trisetum flavescens and Arrhenatherum elatius, which miglt be confused with it, are common.

Oll-seed Plant. Mr. T. W. Cowan gives me this as a popular name for Gold of Pleasure, Camelina sativa. Sometimes called Fatse Frax. 
Old Granny's StIPPER SLoppers. Meadow Vetchling, Lathymis pratensis (East Dorset).

OLd LADY's BonNET. The Columbine, Aquilegia vulgaris (an Ilminster school-girl).

OLD LADy's LACE. Wild Parsley or Chervil, Anthriscus sylvestris (Yeovil). See MI LADY's LACE.

OLd LAdx's Night-CAP. The Canterbury Bell, Campanula media (Aller).

OLD LADY's SHocks. Greater Convo'vulus or Hedge Bindweed, Calystegia sepium (Zeals Wilts).

OLD MAID. The Wall-flower, Cheiranthus Cheiri (Bishopswood).

OLD MAID's BAsket. The Co'umbins, Aquilegia vulgaris (Glastonbury).

OLd MaId's Flower. The Pansy, Viola tricolor (South Petherton and Stalbridge).

OLD MAID's LAST FrIEND. The Pansy, as above (Axminster).

OLD MAID's Scent. A school-boy at West Coker gives me this as a local name for the " Wild. Pyrethrum," by which is almost certainly mant the Feverfew, Chrysanlhemum Parthenium.

OLD MAN. (1) A general name throughout the district for the Southernwood or Boy's-love, Artemisia Abrotonum.

(2) Several correspondents in the Stockland and Kilton district give it as being used in that neighbourhood for the Rosemary, Rosmarinus officinalis.

(3) The Scarlet Pimpernel, Anagallis arvensis (S.W. Wilts).

(4) In some places this name is given to the Wild Clematis or Traveller's Joy, Clematis Vitalba, more often called in this district OLD MAN's BEARD.

OLD MAN's BACCY. A correspondent at East Harptree gives me this as a local name for Dock leaves, but it appears to me more appropriate to Buidock or Coltsfoot.

OLD MAN'S BEARD. (1) A name given throughout the greater part of Somerset and Dorset, as well as other parts, to the Wild Clematis or Traveller's Joy, Clematis Vitalba, on account of the long feathery awns which follow the flowers and remain on the rambling stems for months. Mr. Elworthy said he had never heard the Clematis so called in West Somerset.

(2) The Cornfield Horse-tail, Equisetum arvense (West Somerset) ; called also in the same district MARE'S-TAIL and JOINTWEED.

(3) A fairly general name for the bushy bedeguar or "Robin's Pincushion," frequently found on the Dog-rose. 
(4) Southernwool o: Boy's-love, Artemisia Abrotonum (Dosset and Wilts).

(5) A number of young people at Tho:ns St. Maigaret give ma this as a local name fo" "Watergrass." Probably either Phalaris arundinacea $\mathrm{O}_{2}$ Phragmites communis when in seed.

(7) One of the many popular names for Saxifraga samentosa. S AARON'S BEARD (2).

(6) Meadow-sweet, Spiraca Ulmaria (a schoogirl at Otter hampton).

(8) Səe Grandfather's Beard (4).

OLd MAN'S BREAD AND CheEsE. Common Mallow, Malva sylvestris (Ubley). Sae Bread AND Chense (2).

OLd MAN's Buttons. (1) The Marsh Marigo'd, Caltha palustris (South and East Somerset and Do:set).

(2) Applied also to several species of Buttercup, Ranunculus.

(3) Burrs of the Buidock, Arctium minus (Membury, Devon).

OLD MAN's CLOCK. Dandelion, Taraxacum officinale (Stour Piovost, Dorset).

OLd MAN's FACE. (1) The Pansy, Viola tricolor.

(2) The Snspdragon, Antirrhinum majus (Stockland, Devon).

OLD MaN's FLANNEL. Gieat Mullein, Verbascum Thapsus.

OLD MAN'S FLOWERS. A correspondent at Barrington gives mo this as a local name for flowets something like the Eltrot, Heracleum Sphondylium, having long, hollow, hairy stems, and growing with buttercups.

OLd MAN's FRIEND. Scarlet Pimpern 3 l. Anagallis arvensis (a school-girl at Muchelney).

OLd MAN's GLass ExE. Scarlet Pimpernal, as above (Staple Fitzpaine).

OLD MAN's HAT. The Garden Lily (a schoo:girl at Otterhampton).

OLD MAN'S LOOKING-GLASS. A number of young people at Paulton give me this as a local name fo: the Scarlet Pimpernel, Anagallis arvensis; no doubt through confusion with OLD (OR POOR) MAN'S WEATHER-GLASS.

OLD MAN's NIGHT-CAP. (1) Greater Convolvulus or Hedge Bindweed, Calystegia sepium.

(2) Lesser Convoivulus or Field Bindweed, Convolvulus arvensis.

OLD MAN's Pepper. (1) Common Yarrow, Achillea Millefolium.

(2) Several young people at Evershot give me this as a local name for the Salad Burnet, Poterium Sanguisorba. 
OLd MAN's PEPPER-Box. Snaeze-wot Yariow, Achillea Ptarmica (Wambrook).

OLd MAN's PULPIT. Wild Arum Oi Cuckoopint, Arum maculatum (Combe St. Nicholas).

OLD MAN's SHIRTS. Greater Convolvulus, Calystegia sepium (Yetminster).

OLD MAN's SNUEF-BOx. A puffball fungus, Lycoperdon. See DEvIL's SNUFF-Box.

OLD MAN'S WEATHER-GLASS. A fairly general name throughout the district for the Scarlet Pimpernel, Anagallis arvensis.

OLD MIAx's WHISKERS. Several correspondents in the Ilminster district give me this as a local name fo: the Wood Horsetail, but as this plant, Equisetum sylvaticum, is very rare in the county I imagine there is some confusion of the species. Di. Downes suggests the plant intended is $E$. maximum.

OLd MEN's BeARd. Same as OLd MaN's BEARD (2).

Otd Mex's Butrons. Marsh Marigold, Caltha palustris.

OLD MEN's Matches. A correspondent at Coombe Bissett (IVilts) gives me this as a local name for the "Scarlet Cup lichen," Cladonia coccifera.

OLd MEN's TRousers. A correspondent at Pawiett gives me this as a local name fo: the Iris.

OLD Mother THYuE. Wild Thyme (Dunster). See NoTHER THYME.

OLD Rock. A compuption of OLD ROT (which see), sent me from Pawlett and other places.

OLd Root or OLd Rot. Rev. Wm. Barnes gives this as the Somerset form of ELTRoT, which he defines as "The stalk and umbel of the Wild Parsley." But ELTRoT is the usual name in East Somerset fo: the Cow-parsnip, Heracleum Sphondylium.

OLD ROT. A number of correspondents in the no:thern part of Somerset give me this as a local name for the Cow-parsnip, Heracleum Sphondytium. Probably another form of ELTRoT, which see.

OLD Sow. The Wilts Glossary gives this as being used rarely in N. and S.W. Wilts for Melilotus corulea, from its peculiar odour. It is not easy to anderstand this, as Mrr. T. W. Cowan points out the common name of IIelilotus corulea is Sweet Trefoil, for which OLD Sow is bardly appropriate.

OLd UNCLE HARRY. MIgwort, Artemisia vulgaris (Winsham). 
OLd Woman's Bonnet. (1) The Columbine, Aquilegia vulgaris. Move often called GRANNY's BONNET.

(2) Greater Convolvulus oi Hedge Bindweed, Calystegia sepium (Martock and East Devon).

(3) Canterbury Bells, Campanula media (Chewton Mendip).

(4) Shepherd's Purse, Capsella Bursa-pastoris (Winsham).

(5) Water Aven;, Geum rivale (Mere, Wilts).

OLd Woman's Ere. The Periwinkle, Vinca (Fontmell Parva, Dorset).

OLD Woncax's NeEdLE-WORK. Red Spur' Valerian, Kentranthus ruber (Taunton). See LADY'S NEEDLEWORK (1).

OLd Woman's NigHT-CAP. (1) Greater Convolvulus, Calystegia sepium.

(2) The Monk's-hood, Aconitum Napellus (Brompton Regis).

(3) Canterbury Bells, Campanula media (Aller).

(4) A schoo-girl at Buckland St. Mary gives it as a local name for the Deadiy Nightshade, which I have no doubt is an error for the Woody Nightshade, Solanum Dulcamara. See Granny's NIGHTCAP (7). Devon).

(5) The Columbine, Aquilegia vulgaris (East

OLd Woman's Penny. Honesty or Lunary, Lunaria biennis (a comespondent at Tincanton).

Old Woman's Petricoats. The Poppy, Papaver Rhocas (Long Sutton).

OLd Womax's PIN-cushion. The Spotted Orchis, Orchis maculata (S. W. Wilts).

Orid Woman's Purse. The Calceolaria.

OLD Woman's Toe-NaILs. Bird's-foot Trefoil, Lotus corniculatus (Axminster).

Old Woman Threading Her NeEdle. The Herb Robert, Geranium Robertianum (East Somerset).

Oliver Cromterl's Crenping Companion. A name given me by a Yeovil gardener for the small spreading plant Helxine Solierolii, which Dr. Watson tells me is sometimes called (in error) Artillery-plant, and which Dr. R. C. Knight tells me is also called Australian Moss. See Mind Your OWN BUSINESS.

OLLER. The Alder, Alnus rotundifolia.

ONE BERRY. An old country name for the Herb Paris, Paris quadrifolia.

ONE I EAT. A gentleman living in Yeovil gives me this as a popular name for the Strawberry Tree, Arbutus Unedo. Obviously a translation of the specific name Unedo. 
ONE O'CLOCK. (1) A very common name throughout the district for the Dandelion, Taraxacum officinale.

(2) The Star of Bethlehem, Ornithogalum umbellatum.

(3) The Yellow Goat's-beard, Tragopogon pratense (Bradford-on-Tone).

(4) The Cot's-foot, Tussilago Farfara (Lydford-on-the-Fosse).

(5) Greater Stitchwort, Stellaria Holostea (Membury, Devon).

ONE O'ClOCK, Two O'ClOCK. Seed-head of Dandelion (Clapton-in-Gordano).

ONE, Two, THREE. Dandelion, Taraxacum officinale (Wambrook). No doubt from counting the number of puffs required to blow away all the seeds.

UNION Couch. Dr. Watson writes:-"This is a name given at Staplegrove to a kind of grass with little underground bulbs. I have not yet had the grass biought for examination, but it may be a form of Arrhenatherum elatius or Phleum pratense."

ONION FLower. The Broad-leaved Garlic, Allium ursinum.

OnION StInKers. Broad-leaved Garlic, as above (a school-boy at Evercreech).

OPEN AND SHUT. The Star of Bethlehem, Omithogalum umbellatum (Martin, Wilts).

OPEN-ASS. A common name throughout the district for the Medlar, Mespilus germanica. MIr. Elworthy says : "The common and usual name among the working-class, and it appears to be a survival, not perhaps of the fittest according to modern taste, but of a very early period."

OPEN-EYE. Common Daisy, Bellis perennis (Dowlish Wake).

Open JAws. The Snapdragon, Antirrhinum majus (Camerton).

OPEN MOUTHS. Snapdragon, as above (Long Sutton).

OPEN STAR. The Ox-eye Daisy, Chrysanthemum Leucanthemum (school-childien at Paulton). See Littre OpEn Star.

Orange Blossom. (1) Same as Mock Orange.

(2) A school-girl at Ilminster gives me this as a local name for the Lesser St. John's Wort (?).

ORGAN, ORGIN, or ORGANY. (1) Pennyroyal, Mentha Pulegium. Mr. Elworthy says : "Usual name of this herb, which is much grown as a flavouring. The name Penny-royal is unknown. It is chopped small and put into a mess called 'Tea kettle broth,' which is also often called "ORGaN BRoth.'" Rev. H. Friend. 
says : "It is perhaps as well here to observe that thougb Origane, Orgaine, Organy, or Organ, as the word is variously spelt and pronounced, comes from the classical languages (Lat. origanum) and refers to the plant Marjoram, yet in Devonshire, where the people speak of Organs, Organtea, Organ-broth, they mean Penny-royal. Mrs. Palmer, in "Devonshire Courtship," says "I'd make it treason to drink ort but organ tey."

(2) Marjoram, Origanum vulgare.

OrL. The late G. P. R. Pulman gives this a local name in the Crewkern and Axminster district for the Alder, Alnus rotundifolia.

Ostrich PLUMes. A scbool-girl at Dunster gives me this as a local name for the Aster. $\mathbf{M r}$. W. S. Price tells mè it is a gardener's name for a special variety of Aster.

OUR LADY's BAsIn. An o'd country name for the Teasel, Dipsacus sylvestris, from the way in which the leaves unite round the stem to form basins, which are generally found to contain water and drowned insects, on which the plant feeds.

OUR LADY'S CANDLE. The Great Mullein, Verbascum Thapsus.

OUR LADY'S FLANNEL. The Great Mullein, as above.

OUR LADY's HEART. One of the many popular names for Dicentra spectabilis (Martock). Often called BLEEDING HEART, LOCKS AND KEYS, LADY'S LOCKet, ChINAMAN'S BREeches, LYRE FLower, \&c.

OUR LADY's NiGHT-CAP. The Greater Convolvulus, Calystegia sepium.

OUR LADx's SHOck. The Greater Convo:vulus, as above.

OUR LAdx's THumble. The Harebell, Campanula rotundifolia. See LADY's THIBBL (2).

Owler. Miss Audrey Vivian (Trowbridge) gives me this as a local name for the Poplax or Aspen. Mr. T. W. Cowan tells me the name is quite common in the North for the Alder tree.

OWLS' Eres. A correspondent at Bradfordon-Tone gives me this as a local name for the Scarlet Pimpernel, Anagallis arvensis, more often called Poor MaN's WEATHer-gLass. In Herts it is known as "Adder's Eyes."

Oysters. (1) Rev. Hilderic Friend says fircones are known by this name in Devon, because the scales with the seeds nearly enough resemble oyster-shells to suggest the name.

(2) Lilac blossom, Syringa vulgaris, is called "Oysters" in the neighbourhood of South Molton.

(3) From several parts of Wilts, Dorset, and West Somerset this is sent me as a local name for the Aster; no doubt a corruption. 
Paigle. The Cowslip, Primula veris.

Pannt Brushes. (1) The Periwinkle, Vinca (School children at Horton and Hatch Beauchamp).

(2) Fruits of the Goat's beard, Tragopogon pratense (Curry Mallet).

(3) The Knapweed, Centaurea nigra (East Devon).

(4) The Creeping Spike-rush, Eleocharis palustris (Charlton All Saints, Wilts).

Painted Ladies. Pink and White Sweet Peas (Wilts).

Painted LAdy. (1) London Pride, Saxifraga umbrosa (a school-girl at Oake). See PretTy LAdy.

(2) The Striped Crane's-bill, Geranium versicolor (Devon). This is an escape from gardens, fourd in several districts in West Somerset.

Packr. (1) This name was given by our rustics to almost any species of Willow or Sallow, Salix, when bearing catkins, which were formerly gathered by them and used as "Palm" on Palm Sunday.

(2) In addition the late G. P. R. Pulman gives it as being applied to the catkins of the Hazel, Corylus Avellana, in the Crewkerne and Axminster district, and the Rev. H. Friend as being applied to the Yew, Taxus baccata in Devon.

Patiren. A North Dorset form of the name Palm, applied to the Sallow (Leigh).

PALSY-WORT. An cld country name for the Cowslip, Primula veris.

PANCAKE-PLANT. Common Mallow, Malva sylvestris (Stalbridge and East Devon). See PaNS AND CAKES.

PaNCAkes. The Wall Pennywort, Cotyledon Umbilicus-Veneris, from the shape of its leaves.

PANE. His Honour J. S. Udal gives this as a Dorset name for the Parsnip.

PaNS AND CAKES. A school-girs at Queen Camel gives this as a local name for the Common Mallow, Malva sylvestris. See PANCAKE-PLANT.

PAPER BEECH. Common Birch, Betula alba (N.W. Wilts).

PARACHUTES. (1) A name applied in many parts of the district to the seeds of the Thistle or Dandelion on account of the parachute-like pappus which is attached to them.

(2) The Periwinkle, Vinca (Camerton). (Furley).

(3) Canterbury Bells, Campanula media

Paradise LILY. A school-girl at Draycott gives me this as a local name for the Poppy,
Papaver Rhoeas. 
Paradise Plant. Common Mezereon, Daphne. Mezereum. Rev. H. N. Ellacombe, rector of Bitton, said (1869) "the usual name for the shrub in these parts is the "Paradise Plant.' ",

Parasols. (1) Lesser Convolvulus or Field Bindweed, Convolvulus arvensis.

(2) The Salad Burnet, Poterium Sanguisorba (Little Langford, Wilts).

Park Leaves. Common Tutsan, Hypericum Androsomum. Dr. Prior thinks this, as well as its French synonym parcour ( = by heart) are no doubt corruptions, with reference perhaps to its perked (or prickled) leaves.

Parrot's BEAK (or BILL). A popular English. name for a New Zealand plant, Clianthus puniceus ; so called from its curved upper petal.

Parslex Fern. (1) The general English name for the fern Cryptogramme crispa, which Dr. Watson tells me does not occur in Somerset, but is found in N. Devon. It was found near Simonsbath in 1872, but is probably extinct there now.

(2) The Tansy, Tanacetum vulgare, from the resemblance of its leaves to parsley.

PARSOx AND Clerk. The Wild Arum or Cuckoo-pint, Arum maculatum. More often called Papson In the PULPIT.

Parson IN the PULPIT. (1) A common name throughout the district for the Wild Arum or Cuckoo-pint, Arum maculatum.

(2) The Rev. H. Friend says the name is also given to the Monk's-hood, Aconitum Napellus.

(3) A correspondent at Plush (Dorset) gives it as a local name for the Polyanthus.

Pasment. Parsnip (G. P. R. Pulman). See Passment.

Pasmet. Parsnip (Wilts).

Pa'son in the Pulpit. See Parson.

PASque-flower. A name popularly given to almost any species of Anemone blossoming about Easter, but more particularly to the Dane-flower, A. Pulsatilla, of which this is the general English name.

Passment. MIr. F. T. Elworthy gives this as a very common corruption of Parsnip in West Somerset. See PASMEnT.

PAssion Flower. (1) The general English name for the Brazilianplant, Passiflora corulea, said to have been first found by Jesuit missionaries. The whole plant was emblematical to them, and was thus explained:-"The leaves represented the spear which pierced our Saviour's side; the tendrils, the cords which bound His hands, or the stripes with which He was scourged; the ten petals, the ten apostles who deserted Him; the pillar in the 
centre of the flower, the cross or the pillar to which $\mathrm{He}$ was bound; the stamens, the hammers; the styles, the nails; the inner circle around the central pillar, the crown of thorns; the radius round it, the nimbus of glory; the white in the - flower is an emblem of purity; the blue, a type of Heaven."

(2) Miss Ella Ford (Melplash) gives this as a local name for the Anemone. See PAsquEFLOWER.

Patience. (1) Monin's Thubarb, Rumex alpinus. See GARDEN PATIENCE.

(2) The Patience Dock, Rumex Patientia, so called from the slowness of its operation as a medicine.

Mr. T. W. Cowan tells me that this name is probably derived from the French lapace (Latin, lapathium) = sorrel ; misunderstood as la patience. He quotes from Cotgrave, who gives Lapace, as a name for "the ordinary or sharp-pointed dock," and Lapas or Patience for "Monk's Rhewbarb."

Pattens And Clogs. (1) Bird's-foot Trefoil, Lotus corniculatus.

(2) Less frequently, the Yellow Toadflax, Linaria vulgaris.

Patty Carey. A Wiltshire corruption of the name Hepatica.

Paul's Betony. Miss Ella Ford (Melplash) gives me this as a local name for the Germander Speedwell, Veronica Chamaedrys ; this is apparently due to confusion with the Common Speedwell, $V$. officinalis, to which the name was formerly applied.

Peace and Plenty.-Miss Masey, of Taunton, gives me this as a Somerset name for the London Pride, Saxifraga umbrosa. The compilers of the Wiltshire Glossary give it as being applied in S.W. Wilts to a "kind of small double white garden Saxirrage."

PEACH Bexus. The Peach-leaved Bell-flower, Campanula persicifolia (Rev. H. Friend).

Peagles. A form of the name Paigles, used in many parts of Somerset and Dorset for the Cowslip, Primula veris.

Pea Thatches. Bird's-foot Trefoil, Lotus corniculatus (Vells).

Pecksins. Dr. R. C. Knight writes :- "The few apples left in an orchard after the picking is completed. It is used in two ways :-(i) Ther's a vew Pecksins left. (ii) Oh! lef' they vur Pecksins. I feel convinced that the derivation of this word is to be found in this latter rendering $=$ 'Leave them for the pixies,' which would be only a particular case of the very general belief of other days that the pixies must be provided for." See PIXY HoARdiNG and PIXY-WORD. 
Pediar's Basket. The Ivy-leaved Toadflax, Linaria Cymbalaria.

PEE-ABED. The Dandelion, Taraxacum officinale. See PISS-ABED.

PeeP O' DAY. A Martock lady gives me this as a local name for an early Spring flower, yellow and white, having smooth leaves.

PEG-wood. The Spindle-tree, Euonymus europous (Stockland, Devon). See SkIVER TIMBBER.

Pella Mountain. An old English name for the Wild Thyme, Thymus Serpyllum.

Pennies and Halte-pennies. (1) Yellow Rattle, Rhinanthus Crista-galli (Shoscombe).

(2) A school-boy at Bradford-on-Tone gives me this as a local name for the Moneywort, Lysimachia Nummularia.

Penny Flower. The Wall Pennywort, Cotyledon Umbilicus-Veneris.

Penny Grass. Yellow Rattle, Rhinanthus Crista-galli.

Penny Hats and Penny Leaf are both Devonshire names for the Wall Pennywort, Cotyledon Umbilicus-Veneris.

Penny Pies. A fairly general name throughout the district for the Wall Pennywort, Cotyledon Umbilicus-Veneris.

Penny Rattle. Yellow Rattle, Rhinanthus Crista-galli (Tatworth).

Penny Winkle or Penny Winks. A common corruption of Periwinkle.

Penny-wort. (1) The Wall Pennywort, Cotyledon Umbilicus-Veneris, from the shape of its leaves.

(2) The Common White-rot, Hydrocotyle vulgaris, sometimes called Marsh Pennywort.

Pepper Box. Mrr. F. W. Mathews, of Bradford-on-Tone, gives me this as a local name for the Yeliow Rattle, Rhinanthus Crista-galli.

Pepper Boxes. Common Red Poppy, Papaver Rhœas (Hatch Beauchamp); no doubt from the way in which the ripe seeds are shaken out from capsule.

Pepper Pots. Puff-balls; any fungus of the genus, Lycoperdon (Sexey's School). More generally called SNUFE-BOXES.

Periwinkle. A correspondent at Charmouth gives me this as a local name for the Blue-bell, Scilla non-scripta.

Peter's Pence. Honesty o: Lunary, Lunaric biennis (Bloxworth, Dorset). 
Pewterwort. Miss Audzy Vivian, of Trowbridge, gives me this as a local name for the Horse-tail. I find that both this name and that of Scouring-RUsH were formerly given to any species of Equisetum, but particularly to. $E$. hyemale (the Rough Horse-tail), owing to their being much used for polishing pewter dishes and scrubbing wood. The stems contain silica.

Pheasant's Exe (1). The general English name for the genus Adonis.

(2) In West Somerset, the Evergreen Alkanet, Anchusa sempervirens. Often called also WATER FORGET-ME-NOT.

(3) The "Pheasant's Eye" Narcissus, Narcissus poeticus.

(4) The garden Pink, Dianthus Caryophyllus.

(5) A correspondent at Ubley gives this as a local name for the Scarlet Pimpernel, Anagalliz arvensis.

PICK. The fruit of the Sloe, Prunus insititia (Wilts).

PrCK-POCKET. A name applied to a large number of different plants, but most common'y throughout this district to

(1) The Shepherd's Purse, Capsella Bursapastoris. It has been suggested that "pick" is a corruption of "pix" or "pixie," but Mr. Jas. Britten writes me " Oh no !! it relates to a well-known 'game' or see below" for another suggestion under PICK-PURse. See also a note under Moner-BaGs.

(2) Several correspondents give this as. a local name for the Greater Sitchwort, Stellaria. Holostea, and the Rev. H. Friend suggests that in Somerset the name is frequently given to this plant.

(3) From all parts of the district I have had sent me the names of different members of the Parsley family to which this name is given. It appears to be applied almost indiscriminately to plants of this class.

(4) The Hem'ock, Conium maculatum (Watchet and Martock).

(5) Garlic Treacle-mustard or Jack-by-theHedge, Sisymbrium Alliaria (East Devon).

(6) Ivy-leaved Toad-flax, Linaria Cymbalaria (Sexey's School).

(7) The Schoolmaster at Batcombe gives me this (and BIRD'S-EYE) as a local name for Buxbaum's Speedwell, Veronica Toumefortii; no. doubt applied also to the Germander Speedwell, V. Chamoedrys.

(8) Yellow Ston-crop, Sedum acre (Kimmeridge, Dorset).

PICK-PURSE. The Shepherd's Purse, Capsella Bursa-pastoris. Dr. Prior says : "From its robbing the farmer by stealing the goodness of his land." See Pick-Pocket (1). 
PIE Cress. Marshwort, Apium nodiflorum (Devon). See Pigs' Cress (2).

PIE Dishes. A correspondent at Charmouth gives me this as a local name for the "Ice Plant," by which I presume is intended soms species of Mesembryanthemum.

Pierce-snow. The Snowdrop, Galanthus nivalis (Stalbridge). See SNOW-PIERCFR.

PIfFERIDGe Bush. A lady at Compton (near Yeovil) gives me this as a local name for the Barberry, Berberis vulgaris.

Pig Ales or Pig Alus. The fruit of the Hawthorn, Cratogy!s monogyna.

Pig Berries. The fruit of the Hawthorn, as above (East Somerset and Wilts).

PIG DAISY. Common Fleabane, Pulicaria dysenterica (Leigh, Dorset).

PIG Dock. Fool's Parsley, Aithusa Cynapium (Durston).

Pigeons. The winged fruit of the Sycamore, Acer Pseudo-platanus (Sexey's School).

Pigen's FоOT. A Bridgwater schoolmistress gives me this as a local name for the Ranunculus. Mr. T. W. Cowan writes me : "Geranium columbarium is the nume fo: Pigaon's-foot. Crowfoot is a common nome for many species of Ranunculus." But I gather from Mr. F. W. Mathews that in West somerset the nume Pigeon's-foot is sometimes applied to the Upright Meadow Crowfoot, Ranunculus acris.

Piggles. Another (but much less common) form of PAIGLES, which see.

Piggr-Wiggy. The S a p-dragon, Antirrhinum majus (Litton).

Pig-Lilies. Wild Arum or Cuckoo-pint, Arum maculatum (Sampford Arundel).

PIg Nut. The Earth Nut or Hog Nut, Conopodium majus.

PIG O' THE WALl. The Snap-dragon, Antirrhinum majus (Bruton).

Pigis' Alles. See Pig Ales.

Pigs' Berries. See Pig Berries.

Pigs' Bubble. A common name in West Somerset and East Devon for the Cow-parsnip, Heracleum Sphondylium.

Pigs' Chops. (1) A fairly common name for the Snap-dragon, Antirrhinum majus.

(2) The Yellow Toad-flax, Linaria vulgaris (Mid-Somerset).

Pigs' Cole. Cow-parsnip or Hogweed, Heracleum Sphondylium (Devon). 
Pigs' Cress. (1) Stinking Chamomile or Mayweed, Anthemis Cotula (Winsham).

(2) Several young people at Stockland (Devon) give me this as a local name for "Brook-lime," but in view of the confusion to which reference is made under that heading I cannot pretend to identify the plant. Dr. Watson writes me: "Brooklime, Marshwort, and Water-cress are often associated. The reference is probably to Marshwort, Apium nodiflorum, which is sometimes c:lled PIE-cress in Devon, because it is pied with Witcr-cress.

(3) The Nipplewort, Lapsana communis (A school-boy at Evershot).

Pigs' Daisies. The Stinking Chamomile, Anthemis Cotula (North Dorset).

PIGs' EARs. Sedum acre and other species of Stonecrop; on account of the thick fleshy spikes which serve for leaves.

Pigs' Flop. Cow-parsnip or Hog-weed, - Feracleum Sphondylium (East Devon). See Pigs' Bubbles.

PIGs' Flower. The Stinking Chamomile, Anthemis Cotula (North Dorset).

PIGs' Food. Cow-parsnip or Hog-weed, Heracleum Sphondylium (Dorset).

Pigs' Hales, Haws, Heels. Hells, or Isles. The fruit of the Hawthorn, Cratcog is monogyna.

Pigs' Mouths. (1) The Snap-dragon, Antirrhinum majus.

(2) Yellow Toadflax, Linaria vulgaris.

Pigs' Nuts. (1) The Common Earth-nut or Hog-nut, Conopodium majus, for which pigs are fond of grubbing.

(2) The Horse Chestnut, AEsculus Hippocastanum (East Somerset).

(3) Acorns (Martock).

Pigs' Parsley. (1) This name is applied somewhat loosely to various members of the Parsle famil., but most commonly to the Upright Hedge Parsley, Caucalis Anthriscus.

(2) In Durset the name is sometimes given to the Wild Carrot, Daucus Carota.

Pigs' PARSNIP. Cow-parsnip or Hog-weed, Heracleum Sphondylium (West Somerset).

Pigs' Pears. Fruit of the Hawthorn, Cratcegus monogyna (Stogursey). See PIGSY and PIXIE Pears.

Pigs' Rhubarb. Greater Burdock, Arctium majus (Hammoon, Dorset). Dr. Watson writes: "Is not this more likely to be the Butterburr, Petasites ovatus, which is often called, or rather mis-called, "Wild Rhubarb." The plant mentioned, Arctium majus, is not likely to be differentiated by your correspondent from A. minus, and is very much rarer." 
Pigs' Snouts. The Snap-dragon, Antirrhinum majus (Chilton Polden).

Pigsy Pears. Fruit of the Hawthonn (Kilton. and Pawlett district). See PIGS' PeArs and Pixy Pears.

PIG-WEed. (1) White Goosefoot, Chenopodium album (Allerford).

(2) Tne Comfrey, Symphytum officinale (N.W. Witts).

Pilewort. A very general name for the Lesser Celandine, Ranunculus Ficaria, from an old belief, based on the doctrine of signatures, that a decoction prepared from this plant would cure hæmorrhoids.

Pimrose. A very common mis-pronunciation. of Primrose, throughout a great part of the district.

Prnch Me Trght. A school-girl at Dunster gives me this as a local name for the Orchis (? Orchis mascula).

Pincushion. A name given to a number of different plants, but most generally throughout this district to

(1) The Field Scabious, Scabiosa arvensis, and

(2) The Garden Scabious, S. atropurpurea, the white stamens of which have much the appearance of the heads of pins sticking out of a velvety cushion.

(3) The Devil's-bit Scabious, S. Succisa (Bradford-on-Tone).

(4) The Sea-pink of Thrift, Statice maritima.

(5) The Teasel, Dipsacus sylvestris (Shoscombe).

(6) A school-girl at South Petherton gives it as a local name for the Anemone.

(7) Pink Persicaria, Polygonum Persicaria (a school-boy at Evercreech).

(8) The Double Red Daisy (several schoolgirls at Paulton).

(9) Bird's-foot Trefoil, Lotus comiculatus (Dorset).

(10) The Kiảney Vetch, Anthyllis Vulneraria (S.W. Wilts).

(11) Yellow Fumitory, Corydalis lutea (Devon).

Pincushion Flower. The Scabious. See PinCUSHION (1) and (2).

PrNey. A mis-pronunciation of Peony, common throughout the district.

PINK AND White SזK. Half-a-dozen Paulton. school-girls give me this as a local name for Apple blossom, Pyrus Malus.

PINK BEAUTY. Sweet William, Dianthus barbatus (many school-children at Wembdon and Axbridge). 
PINK BIRD's-Exe. Herb Robert, Geranium Robertianum (a school-girl at Lottisham).

PINkIEs. Red Clover, Trifolium pratense (Leigh, Dorset).

PINk More. A rough kind of grass in the meadows which cattle refuse; probabiy some kind of Carex (Wilts Glossary).

Pink Pinafores. The Herb Robert, Geranium Robertianum (Stoke Abbott, Dorset). Compare Dolly's Apron and Print Pinafore.

Pink Weed. Common Knot-grass, Polygonum aviculare (Leigh, Dorset).

Pins ANd NeEdles. (1) Various species of Thistle.

(2) Common Furze, Ulex europaus (East Harptre ).

(3) Fruit of Shepherd's Needle, Scandix Pecten-Veneris (Curry Mallet).

(4) Greater Stitchwort, Stellaria Holostea (Shoscombe).

(5) Field Scabious, Scabiosa arvensis (Bradford-on-Tone).

(6) London Pride, Saxifraga umbrosa (Stalbridge).

Pins' Heads. Red Spur Valerian, Kentranthus ruber (Stoke-under-Ham).

PIPES. Acorns (Hatch Beauchamp). No doubt in consequence of the eups with stalks attached being used as imitation pipes.

PIPE-TREe. Correspondents in Dorset and. Devon send me this name for the Lilac, Syringa vulgaris.

PIPPLAR. A mis-pronunciation of Poplar, at one time very frequently heard in Somerset.

Pipsy Pears (= Pixy Pears). Ia the Watchet district applied to both Hips and Haws, i.e., the fruits of the Wild Rose and of the Hawthorn. Several correspondents in the Bridgwater district give it as a local name for the latter only.

PISS-A-BED. A very general name for the Dandelion, Taraxacum officinale. The plant is said to have a name equivalent to this in every language in Europe. Also in most languages a popular name meaning "lion's tooth." Our English name Dandelion is a corruption of the French dent de lion. See Mess-A-Bed.

Pitcher. A Willow Plant (Rev. Wm. Barnes). Mr. T. W. Cowan says " a pollard willow."

PIxIEs. Greater Stitchwort, Stellaria Holostea (Devon). In some parts of that county the children believe they will be pixy-led if they gather this flower.

PIXY Hoardings. The small apples left on the trees after the "hoard fruit" has been 
gathered. Some apples are sure to be overlooked in the picking, but these must be left untouched, for ill-luck would surely follo: any person who was so greedy as to leave no fruit at all for the pixies or fairies. Many old-fashioned folk in West Somerset make a point of leaving a few apples on every tree in the orchard for the "little folk." See PEcksins.

Pixy Pears. Applied to both Hips and Haws. See Pipsy PeArs.

Pixy Rings. The green rings so ften seen in pastures are supposed to be pixy rings, round which the little people dance on moonlight nights. See FAIRY RINGS.

Pixx Stools. Toad-stools.

Pixy's UMrbellas. Toad-stools.

Pixy Word. A West Somerset form of Pixyhoard. See PIXY Hoardings.

Plenty. Biting Stonecrop, Sedum acre (Melplash, Dorset).

Ploughman's Weather-glass. Scarlet Pimpernel, Anagallis arvensis (S.W. Wilts). More generally called POOR MAN's (or SHEPHERD's) WEATHER-GLASS.

Plume Feathers. Pampas Grass, Gynerium argenteum (Sampford Arundel).

Plum Pudding. Red Campion, Lychnis dioica (A Crewkerne school-girl). See Puddens.

Poison Berries. Fruits of various plants, usually of a bright colour, such as

(1) Wild Arum or Cuckoo-pint, Arum maculatum.

(2) Black Bryony, Tamus communis.

(3) Stinking Iris, Iris foetidissima.

(4) Mountain Ash, or Rowan, Pyrus aucuparia.

PoIson DAIsy. Stinking Chamomile or MFayweed, Anthemis Cotula (Yeovil).

Poison Fingers. Wiid Arum or Cuckoo pint, Arum maculatum (Dorchester).

PoIson Root. Wild Arum, as above (N.W. Wilts).

Pokers. (1) The Great Reed-mace, Typha latifolia; commonly called BULRUSH.

(2) Wild Arum or Cuckoo pint, Arum maculatum (North Petherton).

(3) Red Hot Poker, Tritoma or Kniphofia.

POKEWEED. Chickweed, Stellaria media (Compton, near Yeovil).

PoLE REeD. The Common Reed, Phragmites communis (West Somerset). These long stout reeds are sometimes used instead of laths for making ceilings. The local name may be a 
corruption of Pool-reed, just as Bull-rush is said to be of Pool-rush.

Poriceman's Buttons. The Marsh Marigold, Caltha palustris.

Policeman's Helinet. The Monk's-hood, Aconitum Napellus (A Martock school-boy).

Pollard Flowers. Common Lime or Linden, Tilia vulgaris (Stoke Abbot, Dorset).

Polty ANDERs or AxDrews. A play upon the name Polyanthus; in some parts of Somerset applied also to the Aurizula.

Polly BAKer. Several school (hildren at Aller give me this as a local name for the Ragged Robin, Lychnis Flos-cuculi.

Poury Nut. The Sweet Chestnut, Castanea vesca (Queen Camel).

Pouly Pods. Honesty, Lunaria biemis (A school-girl at Little Toller, Dorset).

PoNd LIIY. The Yellow Iris, Iris Pseudacorus (East Devon).

Ponies' Tarls. The Greater Plantain, Plantago major (Devon).

Poor HEADs. A number of school-children at Otterhampton give me this as a local name for the Reed. (? species.)

Poor JaNe. (1) The Herb Robert, Geranium Robertianum (Sampford Arundel).

(2) The Red Campion, Lychnis dioica (Thorne St. Margaret).

(3) The White Campion, Lychnis alba (Wellington district).

Poor JAN's LEAF. The Houseleek, Sempervivum tectorum. Rev. Hilderic Friend made enquiries with regard to this plant through the TVestern Antiquary, and received a reply from Edward Capern, who said that a lady, a native of Ashford, North Devon, informed him that she had often heard the Houseleek called "Poor Jan's Leaf." The people have great faith in the healing properties of the plant, whence its peculiar designation.

Poor Man's BACCy. Mr. F. W. Mathews tells me that the Coltsfoot, Tussilago Farfara, is often known by this name from its frequent use in the old countryman's pipe.

POOR MAN's BEER. Common Hop, Humulus Lupulus (Miss Ella Ford, Melplash).

Poor Man's Brush. The Teasel, Dipsacus sylvestris (Furley).

Poor MaN's Flannel. Great Mullein, Verbascum Thapsus.

Poor MaN's Friend. Traveller's Joy, Clematis Vitalba (Yeovil), more often known in that part of the county as OLD MLAN'S BEARD. 
Poor Man's Geraniom. One of the many names given to the pot-plant Saxifraga sarmentosa. See AARoN's BEARD (2).

Poor MAN's ORCHID. (1) A name commonly applied to the Spanish Iris, but extended also to other species, both cultivated and wild.

(2) Elowers of the genus Schizanthus.

Poor Man's ParmacetTy. The Shepherd's Purse, Capsella Bursa-pastoris. Parmacetty is a corruption of the Latin sperma ceti, = whale's sperm, "the sovereignst remedy for bruises." The name is said to be a joke upon the Latin name bursa, = a purse, which to a poor man is always the best remedy for his bruises. See MONEY-BAGs.

Poor MAN's PEPPER. (1) Salad Burnet, Poterium Sanguisorba (Melplash, Dorset).

(2) Marsh Valerian, Valeriana dioica (Tisbury).

Poor MaN's Purse. Shepherd's Purse, Capsella Bursa-pastoris (Watchet).

Poor MAN's ToBacco. Colt's-foot, Tussilago Farfara (South Petherton). Cf. Poor MAN's BACCY.

Poor MaN's WEather-GLass. The Scarlet Pimpernel, Anagallis arvensis, from its habit of closing its flowers before rain.

Poor OAts. Wild Oats, Avena fatua (West Somerset).

Poor RoBert. The Herb Robert, Geranium Robertianum (East Devon and Evershot).

Poor RoBIN. (1) The Herb Robert, as above.

(2) A Devonshire name for the Red Campion, Lychnis dioica, commonly known in Somerset as ROBIN HoOD.

Pop-BELl. The Foxglove, Digitalis purpurea (Winsham).

Pop-Bladders. The Foxglove, as above (Melplash, Dorset).

Pop Corns. The Spindle-tree, Euonymus europous (Bradford-on-Tone).

PoP Dock. The Foxglove, Digitalis purpurea (West Somerset).

Pope's Hood (or ODE). An old English name for the Monk's-hood, Aconitum Napellus.

Pop Guns. (1) The Forglove, as above.

(2) Greater Stitchwort, Stellaria Holostea (Clapton-in-Gordano), more commonly called in this district SNAP-JACKS.

(3) The Bladder Campion, Silene latifolia (Milborne Port).

(4) Seeds of the Plantain, Plantago (Bridgwater).

POP-JACK. Greater Stitchwort, Stellaria Holostea (Bridgwater). See SNAP-JACK. 
Poppers, Poppies, or Pops. (1) The Foxglove, Digitalis purpurea, so called because children "pop" the flowers in the same way they would pop a blown-out paper bag. Dr. Dovines tells me that the first of these names is given in the Herbal of Turner, Dean of Wells, in the 16th century.

(2) The Bladder Campion, Silene latifolia (N.E. Somerset and S.W. Wilts). Also " popped" by children as described above.

(3) The Greater Stitchwort, Stellaria Holostea (West Wilts).

Poppr Dock. The Foxglove, Digitalis purpurea (West Somerset).

Pops. See Poppers.

Pop SHELls. A number of school-children at Paulton give me this as a local name for the berries of the Ivy, Hedera Helix.

Pops UPS. A school-girl at Chardstock gives me this as a local name for the Crocus. (? The ATeadow Saffron, Colchicum autumnale, frequently called Upstarts.)

Posy. The garden Peony, from its size (Wilts Glossary).

Potash. MIr. T. W. Cowan tells me he formerly had a gardener from Devonshire who always called the Common Goutweed, Egopodium Podagraria, by this name.

Potatoes IN the Dish. This name is sent me by two correspondents at Marshwood (near Charmouth), one of whom applies it to the Sun Spurge, Euphorbia Helioscopia, and the other to the Wood Spurge, $E$. amygdaloides.

Pots and Ketrles. Fruit of the Box, Buxus sempervirens (Barford St. Martin, Wilts).

Poverty. (1) The Rest Harrow, Ononis repens, from the fact that the plant grows on poor soil and the farmer who has a good crop of Rest Harrow will always remain poor.

(2) Yellow Rattle, Rhinanthus Crista-galli (Combe St. Nicholas). This plant is a partial parasite, and obtains some portion of its nourishment by fastening its suckers on the roots of grass and other plarts growing near and robbing them of their sap.

Poverty Grass. A school-girl at Bishopswood gives me this as a local name for the Plantain.

Poverty WeEd. Yellow Rattle (Chard di.jtrict). See Poverty (2).

Power-Wort. Several correspondents send me this as a name for the Lesser Celandine, Ranunculus Ficaria.

Preacher iN the PUlpit. Wild Arum or Cuckoo-pint, Arum maculatum. 
Pretty AND Litrte. A Devonshire name for the Virginian Stock, Malcolmia maritima; more generally called LrTtue AND PreTtr.

Pretty Betsy. A name given in many parts of Dorset to the Red Spur Valerian, Kentranthus ruber (Dr. Watson).

Pretty Betry. London Pride, Saxifraga umbrosa (Beaminster).

Pretty Lady. London Pride, as above (Trowbridge).

Pretty Nancy. (1) Greater Stitchwort, Stellaria Holostea. See NANCY.

(2) London Pride, Saxifraga umbrosa (Rodden, near Frome).

Pretty Wrulf:. Sweet William, Dianthus barbatus (Pawlett).

Prickly BeE-HIves. The Common Teasel, Dipsacus sylvestris (A school-girl at Alfington, Devon).

Prickly CoAts. The Spear Plume Thistle, Cnicus lanceolatis (Leigh, Dorset).

Prickly GHost. Common Furze, Ulex europous (Leigh, Dorset). "Ghost" is a further corruption of goss $=$ gorse.

PRICK MAdAM. (1) An old country name for the Biting Stonecrop, Sedum acre; said to be a cormution of the French name, Trique Madame, for Triacque it madame, as it were "Lady'streicle."

(2) A well-informed correspondent at Compton (near Yeovil) gives this as a local name for the Houseleek, Sempervivum tectorum, but if the name is so used in that district it would appear to be due to confusion with No. 1.

Prick-wood. (1) The Spindle-tree, Euonymus europous, in consequence of its wood being used for making skewers. Also for the same reason

(2) The Dogwood, Cornus sanguinea.

Pride. A correspondent at Stalbridge gives me this as a local name for the Sunflower, Helianthus annures.

Prioe of the Evening. Honeysuckle or Woodbine, Lonicera Periclymenum (Axminster and. Uplyme district).

PrIDE OF THE MEAdow. Meadow-sweet, Spircea Ulmaria (A school-girl at Oake), more often called QUEEN OF THE MEADOW.

PRIDE OF THE THANES. This is sent ma from. several places in Somerset and Dorset as a name for the Flowering Rush, Butomus umbellatus.

PrIDE of THE WoOds. The Wild Hyaciath or Bluebell, Scilla non-scripta (Camerton).

Priest AND PULprT. A number of young. people at Oakhill send this as a local name for 
the Wild Arum; obviously a corruption of the following name.

Priest in the PUlpit. A fairly common name for the Wild Arum or Cuckoo-pint, Arum maculatum, but less e rmmon than PARSON IN THE PULPIT.

Primprint. Privet, Ligustrum vulgare (Evershot).

Primrose Pearls. The White Narcissus, Narcissus poeticus. This name is sent me from several districts, and particularly from Paulton. Mr. Edward Vivian (Trowbridge) writes: "In some localities it would be difficult to find a person knowing the Narcissus by any other name."

Primrose Prushes. A correspondent of Somerset and Dorset Notes and Queries in 1893 gave this as an old name at Hinton St. George for the White Narcissus, as above.

PrIMrose Soldiers. Garden Columbine, Aquilegia vulgaris (N.W. Wilts).

Prince of Wales' Feather. (1) The Lilac, Syringa vulgaris (Devon).

(2) Golden Feather, Pyrethrum (Muchelney).

(3) The Iris (Castle Cary).

(4) Red Spur Valerian, Kentranthus ruber (Dorset).

Prince's (or Princess) Feather. (1) The Lilac, Syringa vulgaris (West Somerset and Devon).

(2) Love lies Bleeding, Amaranthus (several species).

(3) London Pride, Saxifraga umbrosa (Devon).

(4) The Silver-Weed, Potentilla Anserina (various parts of Somerset).

(5) Golden Feather, Pyrethrum.

(6) Pampas Grass, Gynerium argenteum.

Princess' Robe. The Daffodil, Narcissus Pseudo-Narcissus (Otterford).

Print Pinafores. The Herb Robert, Geranium Robertianum (Marshwood, Charmouth). Cf. Pink Pinafores and Dolit's Apron.

Pripet. Mr. W. S. Price (Wellington) gives me this as a common local mispronunciation of Privet.

Procession Flower. An old English name for the Common Milkwort, Polygala vulgaris. Mrs. Day gives it as a "North Petherton" name still. See GANG-FLOWER.

Propellers. It is remarkable how generally this name and others of a similar character have been adopted within the past few years for the winged seeds of the Maple, Sycamore, \&c. See AFROPLANES. 
Publicans and Sinners. A name sometimes given to Buttercups and Marsh Marigolds because they are often found growing together (Rev. H. Friend).

Puddens. Red Campion, Lychnis dioica (Ubley).

PUfF BALLS. (1) The general English name for fungi of the genus Lycoperdon.

(2) A name given by sehool-children in various parts of the district to the seed heads of the Dandelion, Thistle, \&c.

Puff Clocks. The Seed head of the Dandelion. (Otterhampton). See above.

Punpernat. The Scarlet Pimpernel, Anagallis arvensis (Stogursey).

Purple Berries. A number of young people at Paulton give me this as a local name for the berries of the Elder, Sambucus nigra.

Purple Buttons. Field Scabious, Scabiosa arvensis (Winscombe).

Purple Grass. An old country name for the Purple Loose-strife, Lythrum Salicaria.

Purple Hracinth. Early Purple Orchis, Orchis mascula (Cuilton Cantelo). See note under BLOODY BONES.

Purse-Flower. Shepherd's Purse, Capsella Bursa-pastoris (Sampford Arundel).

Purses. Yellow Rattle, Rhinanthus Cristagalli (Bradford-on-Tone). Səe Moner-BaGs.

Pussies. Great Reed-mace, Typha latifolia (Mid-Somerset).

Puss-TAIL. Meadow Fox-tail Grass, Alopecurus pratensis (High Ham).

Pussy Cats. (1) Catkins of Willow, Sallow Hazel, \&c.

(2) Several correspondents in Bridgwater and the district apply this name to various grassesCouch-grass, Pye-grass, Wild Barley, Foxtail, and Timothy.

Pussy Cats' Tarls. (1) Same as Pussy Cats (1).

(2) Miss Ida M. Roper tells me that the Prickly Twig-rush, Cladium Mariscus, is known by this name at Shapwick (Somerset).

Pussy Face. The Pansy, both cultivated, Viola tricolor, and wild, $\nabla$. arvensis.

Pussy Foot. White or Dutch Clover, Trifolium repens (Watchet).

Pussy (or Pussy's) Fur. Catkins of Willow and Sallow (Wiveliscombe and Evercreech).

Pussy Parm. Catkins of Willow and Sallow 
Pussy's TaILs. (1) Catkins of Willow, Sallow Hazel, \&c.

(2) Great Reed-mace or Cat's-tail, Typha latifolia; commonly called Bulrush (Aruchelney).

Pussy Willow. The Catkins of Willow and Sallow.

Puzzle Monkey. The Chilian Pine, Araucaria imbricata; more often called MONKEY Puzzle, which see.

QUAKER Grass or QUAKers. Quaking Grass, Briza media.

QUarantine, Quarenden, or QuarRener. A deep red early kind of apple; a common favourite in Somerset and Devon.

Queen ANne's Lace. Wild Beaked Parsley, Anthriscus sylvestris (Dorset). See MiY LADY'S LACE.

QUEen ANNE'S NEEdLE-TrorK. Red Spur Valerian, Kentranthus ruber (Bruton). See LADY's NEEDLE-WORK (1).

Queen Anne's Plumes. Pampas Grass, Gynerium argenteum (Maunsel).

QUeEN Elizabeth IN Her Bath. Another of the many popular names given to Dicentra spectabilis; known as the LYRE-FLOWER, LADY'S LOCKET, BLEEDING HEART, CHINAMEN's BREeches, \&c.

Queen (or QueEn's) Feather. The Lilac, Syringa vulgaris (more particularly in Devon).

QUEen Flowers. The Lilac, as above (Charmouth).

QUEen of HeARts. Large-flowering St. John's . Wort, Hypericum calycinum; often called Ross of Sharon (Miss Ella Foid, Melplash).

QUeEN OF THE MIARshes. Yellow Iris, Iris Pseudacorus (Evercreech).

QUEEN OF THE Meadow. A very general name throughout the district for the Mradow-sweet, Spircea Ulmaria.

Queen of THe MIst. London Pride, Saxifraga umbrosa (Miss Elia Ford, Melplash).

QUEEN OF THE RIVER. Yellow Water-Lily Nymphoca lutea (Miss Ella Ford, MIelplash).

QUEEN'S FEATHER. (1) The Lilac, Syringa vulgaris (Devon).

(2) The Meadow-sweet, Spirca Ulmaria (Perry Street, Chará).

Quick. The Hawthorn, Cratagris monogyna, particularly young plants used fo: razking hedges.

QuICK BEAMr. The Mountain Ash, Pyrus Aucuparia (West Somerset and Devon).

QUICK GRASS. Couch-grass, Agropyron '(formerly 'Triticum) repens. See QUITCH. 
QUICK IN HAND. A Devonshice name for the Balsam or Touch-me-not, Impatiens Noli-tangere,

QUIET NeIGHbours. Red Spur Valerian, Kentranthus ruber (Longbridge Deverill, Wilts).

QUINANCY-WORT or QUINSEY-WORT. The Small Woodruff or Squinancy-wort, Asperula cynanchica; referring to its former use in disorders of the throat.

QUITCH. Couch-grass, Agropyron (formerly Triticum) repens. See Couch.

RABBIT FLower. (1) Yellow Toad-flax, Linaria vulgaris (Devon). See RABBITs (1).

(2) Ivy-leaved Toad-flax, Linaria Cymbalaria (Devon).

(3) A name occasionally given in S.W. Wilts to Dicentra spectabilis, on account of the flowers, when pulled apart, forming two little pink rabbits.

RABBITS. (1) Yellow Toadflax, Linaria vulgaris, because the flowers of the Toadflax open and shut when pressed, exactly as the mouth of a rabbit does. See RABBITS' Mouths.

(2) For the same reason, Antirrhinum majus and other varieties of Snapdragon.

RABBits' BeEF. Plantain (Martock).

RaBbits' Chops. Yellow Toadflax, Linaria vulgaris (Milborne Port). See RABBITs' Modths (2).

RABBITS' EARS. (1) The woolly-leaved garden plant, Stachys lanata; called also DONEEY's-EAR and Mouse's-EAR (Horton and Pawlett).

(2) Plantain (a school-girl at Hawkchurch).

Rabirts' Meat. A name applied to a number of plants on which rabbits feed ; most frequently in this district to

(1) The Sow Thistle, Sonchus oleraceus.

(2) Cow-parsnip or Hog-weed, Heracleum Sphondylium.

(3) Leaves of the Dandelion, Taraxacum officinale.

(4) The Wood Sorrel, Oxalis Acetosella (Pilton).

RABbits' MoUths. (1) A general name throughout the district for the Snapdragon, Antirrhinum majus.

(2) Yellow Toad-flax, Linaria vulgaris.

(3) Ivy-leaved Toad-flux, Linaria Cymbalaria.

(4) The Ground Ivy, Nepeta hederacea (a school-girl at Awliscombe, Devon).

RAE BIts' PUdding. Leaves of Plantain (Bridgwater).

Rabbits' Viddles (or Vitplaes). (1) Sow Thistle, Sonchus oleraceus. See RABbits' MEAT (1 and 2).

(2) Cow-parsnip or Hog-weed, Heracleum Sphondylium. 
RAckiss. A very common corruption of the name Auricula.

RACKzen or RAXEN. Mr. F. W. Mathews, of Bradford-on-Tone, gives me this as a local name for

(1) The Flowering Rush, Butomus umbellatus; and

(2) The "small" Rush, by which is probably meant the Toad-rush, Juncus bufonius. The term is probably applied, more or less, to all Rushes. See RExen.

RAGGED JACK. (1) The plant to which this name is most commonly given in this district is the Ragged Robin, Lychnis Flos-cuculi.

(2) Greater Knapweed; Centaurea Scabiosa (Batcombe).

(3) The Red Campion, Lychnis dioica (Melbury Osmond).

(4) The Scarlet Pimpernel, Anagallis arvensis (a school-girl at Combe St. Nickolas).

(5) The Ragwort, Senecio Jacobcea (a schoolgirl at Stockland, Devon).

Nos. 3 and 4 are evidently misapplications, due to confusion.

RAGGED $J_{\text {ACKETS. A young man living near }}$ Charmouth gives me this as a local name for the "Robin Hood," by which is usually unjer tood the Red Campion, Lychnis dioica, but I think he means the Ragged Robin, L. Floscuculi, which is often miscalled "Robin Hood" in Dorset and other places.

RAGGED RoBIN. (1) The general English name for Lychnis Flos-cuculi.

(2) Frequently misapplied through confusion to the Red Campion, Lychnis dioica, more often known in this district as ROBIN HOOD. Also to

(3) The Herb Robert, Geranium Robertianum.

(4) The Bladder Campion, Silene latifolia (Somerton).

(5) Great Hairy Willow-herb, Epilobium hirsutum (Keinton Mande: ille).

(6) Purple Loosestrife, Lythrum Salicaria (Tisbury).

RAGGed SHIrT. Field Convolvulus, Convolvulus arvensis (a school-girl at Ilminster).

RAGGed URCHIN. Ragged Robin, Lychnis Flos-cuculi (a school-gurl at Stockland, Devon).

Rags and Tatrers. (1) The Common Mallow, Malva sylvestris (Somerset and Dorset). ton).

(2) The Columbin?, Aquilegia vulgaris (Camer-

RAG-WWED, Common Ragwort, Senecio Jacoboea (Martock).

Rainbow Flower. The Iris (Yeotil).

RAMrbling (or Roving) SAIlor. The Ivyleaved Toactflix, Linaria Cymbalaria. 
RAxP. Broad-leaved Garlic, Allium ursinum (Winsham, and Leigh, Dorset).

Rars' Claws. (1) The Creeping Buttercup, Ranunculus repens, and more particularly thestalks. Mr. Elworthy says : "The stalks of the common buttercup (Ranunculus acris) when overgrown. In some seasons, especially wet ones, the buttercup attains a rank growth, and the cattle refuse to eat it, so that the meadow, if not mown for hay, becomes covered with coarse stalks without leaves, but still bearing the yellow flowers on the top-these are called RAw's Claws. The name is analagous to BENT or BONNET applied to grasses." Mr. Onions suggests the name is a corruption of Ranunculus.

(2) Coltsfoot, Tussilago Farfara (Yarlington).

(3) Chickweed, Stellaria media (a school-boy at Babcary, who gives a large number of other names quite correctly).

Ramser or Raisies. The Broad-leaved Garlic, Allium ursinum. See RAJSONS.

RAM'S-FOOT Root. The root of the Avens or Herb Bennet, Geum urbanum, which is said to be exactly like a hare's foot, but very little like a ram's (Devon, Rev. H. Friend).

RAmS' GLAss. The Acrid Buttercup, Ranunculus acris (Allerford). No doubt a corruption of RAJis' Claws, which see (1).

RAsrsons. The Broad-leaved Garlic, Allium ursinum. See RAMSEY and RANSOMS.

"Ramsons tast like garlisk: they grow much in Cranbourne-chase : A proverb,

Eate leekes in Lide, and ramsins in May,

And all the yeare after physicians may play." Aubrey's Wilts M.S., p. 124.

Ransours. A common corruption oi Ramsons.

Rantipole. The Wild Carrot, Daucus Carota (N.W. Wilts, English Plant Names).

RAPHONTIC. Several correspondents in various parts of Somerset and Dorset send me this as a name for Rhubarb. I cannot trace the name, and assume it has been copied from some book. Dr. Watson tells me that the garden Rheubarbs are Rheum raphonticum and $R$. undulatum.

RAPPERs. Flowers of the Foxglove, Digitalis purpurea (Wilts). See POPPERS.

Rathe Prinrose. Miss Audrey Vivian (Trombridge) tells me this term is commonly used in that neighbourhood for an early Primrose.

RATHE-RIPE. (1) An early kind of apple: yellow codling with pinkish streaks. See RETHERRIPE.

(2) An early kind of pea (Wilts).

Rats and Mice. Common Hound's-tongue, Cynoglossum officinale (Tisbury). 
Rat's Bane. Wild Heaked Parsiey, Anthriscus sylvestris, a common wild umbelliferous plant, in appearance something like Hemlock-probably mistaken for it (West Somerset).

RAT's Foot. A school-girl near Axminster gives me this as a local nome for the Ground Ivy, Nepeta hederacea. See Rats' Mouths (1).

RATS' Mouths. (1) A number of young people in East Devon give me this as a local name for the Ground Ivy, Nepeta hederacea.

(2) A boy and girl at Sector, near Axminster, give it as a local name for both the White and Red Dead Nettle, Lamium album and L. purpureum.

RATs' TAILs. (1) The seeu-stalks of various species of Plantain.

(2) Common Agrimony, Agrimonia Eupatoria ('Tisbury).

Rattue BAGs. Yellow Rattle, Rhinanthus Crista-galli (Dorset). More often called RATTLE BAskets.

RAtThe BAskets. (1) The Yellow Rattle, Rhinanthus Crista-galli.

(2) The Lousewort or Red Rattle, Pedicularis sylvatica (Winsham).

(3) A Martock school-boy gives me this as a local name for the Soft Rush, Juncus effusus. I gather from Dr. Watson that this rush is used for making little baskets, inside which are placed small peas or similar bodies to make a rattle.

(4) A Muchelney school-boy gives it for the Quaking Grass, Briza media.

Rattre Grass. The Yellow Rattle, Rhinanthus Crista-galli (White's Bristol Flora).

RATTuE PoDs. The Red Rattle or Lousewort, Pedicularis sylvestris (several school-children at Chew Magna).

RAtrue Traps. The Yellow Rattle, Rhinanthus Crista-galli (Marshwood, Dorset).

Ratrue Weed. The Bladder Campion, Silene latifolia (N.W. Wilts).

RAXEN. Rushes. See RAckzen and RExen.

RAY-GRASS. Common Rye-grass or Darnel, Lolium perenne. See EvER-GRass. Prior says the first part of the word represents French ivraie = drunkenness, from the supposed intoxicating quality of some speeies. In the north of England it is named Drunk or Drunken Darnel.

\footnotetext{
RECKLess. A common corruption of "Auriculas."

Rections. Rushes (East Devon). See Rexen.

Red APPle Blossoy. Pyrus japonica (a schoolgirl at Wellington).
} 
RED BIRD's Ere. Scarlet Pimpernel, Anagallis arvensis (a school-girl at Hawkchurch).

RED BoBBy's EYE. Herb Robert, Geranium Robertianum (Redlynch, Wilts).

REDBREAsT. A lady at Wookey gives me this as a local name for the Ragged Robin, Lychnis Flos-cuculi, but it is more generally applied to the Herb Robert, Geranium Robertianum.

RED Butchers. The Red Campion, Lychnis dioica (West Glos.).

Red CAP. Common Poppy, Papaver Rhcas.

Red Clematis. One of the Virginia Creepers, Ampelopsis hederacea ; frequently called "Fiveleaved Ivy."

RED CUP. Common Poppy, Papaver Rhoeas (Otterhampton).

Red Cushions. Common Red Clover, Trifolium pratense (Evercreech).

RED Dolly. Common Poppy, Papaver Rhœas (Long Sutton).

RED Fingers. The cultivated Ciimson Clover, Trifolium incarnatum (a school-girl at South Petherton).

Red Hot Poker. (1) A very general name for the Flame-flower or Torch-lily, Kniphofia. aloides (formerly Tritoma Uvaria), sometimes called DEvir's Poker.

(2) The Wild Arum or Cuckoo-pint, Arum maculatum.

(3) Ribwort Plantain, Plantago lanceolata (a school-girl at South Petherton).

(4) Sumach, Rhus (Wiveliscombe).

(5) The Gladiolus.

Red Huntsman. Common Poppy, Papaver Rhoeas (a school-girl at Minehead).

RED IVx. One of the Virginia Creepers, Ampelopsis hederacea (Chewton Mendip). See ReD Clematis.

RED JANE. The Red Campion, Lychnis dioica (Mr. W. S. Price, Wellington).

Red Jornts. Pink Persicaria, Polygonum Persicaria (Leigh, Dorset).

Red LEGs. Pink Persicaria, as above (Welling ton and Barton St. David).

Red Monex. Red Spur Valerian, Kentranthus ruber (Pensford).

RED NAP. Common Poppy, Papaver Rhoas (Wiveliscombe).

RED PrImRose. A common name for a red. form of the garden Polyanthus.

Red Rags. Common Poppy, Papaver Rhoas (Wimborne). 
ReD RATtLe. Lousewort, Pedicularis sylvatica.

RED RIDING HOOD. A very general name for the Red Campion, Lychnis dioica, commonly known also as RoBIN Hood. A few correspondents in Dorset give me the name as being applied to the Ragged Robin and the Herb Robert, but this is almost certainly due to confusion.

Red Robin. (1) The Red Campion, Lychnis dioica.

(2) The Herb Robert, Geranium Robertianum.

(3) The Ragged Robin, Lychnis Flos-cuculi (Wellow and Mells).

(4) Bird Knot-grass, Polygonum aviculare (Rev. H. Friend).

RED ROBIN-HOOD. The Red Campion, Lychnis dioica (Zeals, Wilts).

RED Roт. Round-leaved Sundew, Drosera rotundifolia.

RED RougHs. His Honour J. S. Udal gives this as a Dorset name for the Scarlet Runner. I am indebted to Dr. Watson for the following note:-"Phaseolus multiflorus is the Scarlet Runner, but I am uncertain whether this is the species meant. The name is quite likely to be applied also to $P$. vulgaris."

Red Soldiers. Common Poppy, Papaver Rhoeas.

Redweed. (1) Common Poppy, Papaver Rhocas. This is the only name for the Poppy in many, parts of Wiltshire, where the name "Poppy" is applied only to the Foxglove.

(2) Bird Knot-grass, Polygonum aviculare.

(3) Scarlet Pimpernel, Anagallis arvensis (Hammoon, Dorset).

RED WoLF. A Bridgwater school-mistress gives me this as a local name for the Red Campion, Lychnis dioica. This flower is very commonly called RED RIDING-HOOD, and, this is possibly the explanation of the "Wolf."

REED. (1) A general name for Phragmites communis.

(2) Often applied to any plant having long and erect leaves and fringing ditches and streams.

(3) A Somerset and Devon word for unbroken wheaten straw, combed and straig utened for thatching, hence to "reed" or thatch a house.

REED-MACE. The general English name for Typha latifolia. More popularly called BuLrush. According to Dr. Prior the plant owes its name of REED-MACE to the "Ecce Homo" pictures, and familiar statues of Jesus in His crown of thorns, with this reed-like plant in His hand as a mace or sceptre.

REED Mote. A single stalk of Wheat Straw. 
Rent DaIsies. A correspondent at Melbury Osmond (Dorset) gives me this as a local name for the Michaelmas Daisy, which covers several species ot Aster. I presume the name has reference to the fact that rent is due at Michaelmas.

Rest Haven. The Evening Primrose, Enothera biennis (Miss Ella Ford, Melplash).

RETHER-RIPE. The West Somerset form of RATHE-RIPE; an early kind of apple. Mr. W. S. Price (Wellington) writes "RETHER-RIPE (three syllables) is always used in this neighbourhood, and I doubt if farmers would recognize the name RATHE-RIPE (two syllables)."

Rex-Bush. A clump of Rushes (always, in West Somerset). A very old saying is "The Barle and the Exe do botb urn out o' the same REX-BUsH." The meaning is that the two rivers with such different courses rise very close together (F. T. Elworthy). From A.S. resce.

RExen. Rushes. One of the very few words which retain the en plural; even this is now becoming "improved "into Rexens. (Compare, chickens). Mr. W. S. Price tells me that Rexies is a more common form than RExEN in the Wellington district.

RHUBARB. The young shoots of the Common Bramble or Blackberry, Rubus fruticosus, wnich I presume ace eaten by children (a school-girl it Bradford-on-Ton:). Compare SUgAR-CANDY.

Rib-Grass or Ribwort. The Ribwort Plantain, Plantago lanceolata.

RrCE. Miss Ella Ford, of Melplash, gives me this as a local name for

(1) The Crosswort Bedstraw, Galium Cruciata.

(2) The Water Bedstraw, Galium palustre.

(3) The Woodruff, Asperula odorata. See RICE FLOWER.

(4) Rev. Wm. Barnes gives this as a Dorset word for brushwood.

(5) Mr. T. W. Cowan writes me:-RICE is a Sussex word for underwood cut sufficiently young to bear winding into hedger or hurdles. It is the modern form of A. Sax. hris, a thin branch (Parish).

RICE FLower. Woodruff, Asperula odorata (Brompton Regis and Melbury Osmond).

Rigalers. A common corruption of "Auri" culas."

Rishes. Mr. W. S. Price gives me this as a West Somerset pronunciation of "Rushes."

Rising Sun. The Ox-eye Daisy, Chrysanthemum Leucanthemum (Camerton).

Road to Heaven. Miss Ella Ford, of Melplash, gives me this as a local name for Jacob's Ladder or Greek Valerian, Polemonium caruleum. 
ROAST BEEF. The Stinking Iris, Iris foetidissima; from the smell of the bruised leaf.

ROBBERS' LANTERNS, A correspondent at Cerne Abbas gives me this as a local name for the flowers of the Horse Chestnut, Esculus Hippocastanum.

ROBERT THE HERBIST. A school-boy at Dunkerton gives me this as a local name for the Geranium. It looks very much like a curious corruption of the name Herb Robert, Geranium Robertianum.

Robin or Robin Flower. (1) Rev. Hilderic Friend gives both these forms as Devonshire names for the Red Campion, Lychnis dioica, and also for Herb Robert, Geranium Robertianum.

(2) Mr. T. W. Cowan writes :-RoBIN or ROBIN-RUN-IN-THE-HEDGE, is given in some counties as tine name for the common Bindweed, Calystegia sepium.

RoBIN HooD. (1) A name generally used throughout the district for the Red Campion, Lychnis dioica.

(2) Used in many parts of the district for the Herb Robert, Geranium Robertianum.

The Rev. H. Friend says "The people living a few miles from Taunton call the Herb Robert and the Campion both Robin Hood."

(3) In Dorset, and occasionally in Somerset, this name is given also to the Ragged Robin, Lychnis Flos-cuculi.

The name is also given occasionally to the three following flower:s, no doubt owing to their resemblance to the $\mathrm{R}$ ed Campion.

(4) The White Campion, Lychnis alba,

(5) The Bladder Campion, Silene latifolia,

(6) The Corn Cockle, Lychnis Githago (given by a school-boy at Wootton Fitzpaine, Dorset).

Robin Hood and His Merry Men. The Scarlet Elf-cup Fungus, Geopyxis coccinea (Rampisham, Dorset).

RobIN REDBREAst. The Red Campion, Lychnis dioica.

Robin RUN in the Field. Lasser Convolvulus, Convolvulus arvensis.

Robin RuN IN THE Hedae. (1) Greater Convolvulus, Calystegia sepium.

(2) Goost-grass, Galium Aparine; commonly called CLYDER or SWEETHEARTS.

(3) Ground Ivy, Nepeta hederacea (Over Stowey).

(4) Red Campion, Lychnis dioica (Leigh, Dorset).

Robins. Red Campion, as above (Taunton). More often called ROBIN Hood. (1).

Robin's Cushion. Sse Robin's Pincushion 
RobiN's ExE. (1) The Herb Robert, Geranium Robertianum.

(2) The Red Campion, Lychnis dioica.

RobIN's Flowers. The Herb Robert, Geranium Robertianum (Cheddar Valley).

RoBIN's PINCUshion. (1) The bedeguar or mossy gall found on the Wild Rose; often called OLD MAN'S BEARD.

(2) Field Scabious, Scabiosa arvensis (Cerne Abbas). See Pincushion (1).

Roв Roys. The Red Campion, Lychnis dioica (Combe St. Nicholas).

ROE-BRIAR. The large Dog-rose briar (Rev. W. P. Williams).

Rogation Flower. Common Milkwort, Polygala vulgaris. See GANG-FLOWER.

RogUERY. Red Spur Valerian, Kentranthus ruber.

Roman CANDles. (1) The Horse Chestnut, Asculus Hippocastanum (Draycott). See CHRISTMAS CANDLES.

(2) The "Red-hot Poker" or Flame-flower, Kniphofia aloides.

(3) A school-girl at Furley gives me this as a local name for the Iris.

RoMAN JASMINE. His Honour J. S. Udal gives this as a Dorset name for the Mock Orange, Philadelphus coronarius.

Rook's FLower. Wild Hyacinth or Bluebell, Scilla non-scripta (Luppitt, Devon).

RopewIND. Field Convolvulus or Bindweed, Convolvulus arvensis.

Rose Among the Thorns. The Fennelflower, Nigella damascena (Maunsel). More commonly called LOVE-IN-A-MIST Or DEVIL-IN-ABusH.

Rose BAx. (1) The Rose-bay Willow Herb, Epilobium angustifolium ; sometimes called FRENCH WILLOW.

(2) A lady at Compton, near Yeovil, gives me this as a local name for the Rhododendron.

Rose Mallow. The Hollyhock, Althoea rosea.

Rose of Heaven. Several correspondents send me this as the popular name of as species of Agrostemma. I believe the particular plant is Agrostemma Coeli-rosa, or the Smooth-leaved RoseCampion, and that it come's from the Levant.

Rose of SHARoN. Large-flowered St. John's Wort, Hypericum calycinum.

Rosemtes. Dahlias (Camerton).

Rosy DANDRUar. A common corruption of the name Rhododendron. 
Rosy HEART. Another of the many names for Dicentra spectabilis; see BLEEDING HEART and LADY's HEART. This name is sent me from Trowbridge.

Rosy Morn. Bird's-foot Trefoil, Lotus corniculatus (Chewton Mendip).

Rotrle Penny. The Yellow Rattle, Rhinanthus Crista-galli (Dorset).

Round-Dock. The Common Mallow, Malva sylvestris, so called from the roundness of its leaves.

According to Jennings the leaves of this plant were used in his day as a supposed remedy or charm for the sting of a nettle, by being rubbed on the stung part, with the words :

In dock, out nettle,

Nettle have a-sting'd me.

Round RoBIN. The Red Camapion, Lychnis dioica, to distinguish it from the Ragged Robin (Devon).

RodND Towers. Purple Loosestrife, Lythrum Salicaria (a school-girl at Alfington, Devon).

Roving SAILoR. (1) Ivy-leaved Toadflax, Linaria Cymbalaria.

(2) The once-popular pot-plant. Saxifraga sarmentosa, often called Mother of THOUsANDs, Strawberry-plant, Spider-plant, Poor MaN's Geranium, \&c. See aAron's Beard (2).

ROWBERRY. This is given me by several school-cbildren in the Chard district as a local name for the "Mandrake" or (and) the "Deadly Nightshade." I assume the plants intended are the Red-berried or White Bryony, Bryonia dioica or (ard) the Woody Nightshade, Solanum Dulcamara.

ROWET or Rowets. Rough coarse grass; particularly that growing up among furze or brushwood. Rough tufts of grass.

Royal Penny. Wall Pennywort, Cotyledon Umbilicus-Veneris (Brompton Regis).

RUE-FERN (or WALL-RUE). Rue-leaved Spleenwort, Asplenium Ruta-muraria.

RUE-WEED. Common Meadow Rue, Thalictrum flavum.

RUNPET SCRUMPS. A school-girl at Ilminster gives me this as a local name for the Cow-parsnip, Heracleum Sphondylium. See LUMPER-SCrUMP.

RUN-AWAY JACK. The Ground Iry, Nepeta hederacea.

RUNning Jacob. The Nasturtium, Tropcolum (Leigh, Dorset).

RUSTY BAck. Scaly Spleenwort, Ceterach officinarum. 
Rusty Coats. Russet Apples.

SAtLoR's Buttons. Field Scabious, Scabiosa arvensis, and Devil's-bit Scabious, S. Succisa (Hawkchurch, Devon).

St. Anthony's Nut. The Pig-nut (Conopodium majus) is often called St. Anthony's Nut, because that saint was the patron of pigs, and for a similar reason the Ranunculus, whose tubers are a favourite food for those creatures, was called St. Anthony's Turnip or Rape (Rev. H. Friend).

St. Barbara's Cress (or Herb). Common Winter-cress, Barbarea vulgaris. Often called. YELLOW ROCKET.

St. George and the Dragon. Two schoolgirls at South Petherton give me this as a local name for the Petunia. A school-girl at Cutcombe gives me ST. GEORGE's Dragon as the local name of a flower of which I have been unable to get from her the proper name or any satisfactory description.

St. Jantes's Wort. (1) Common Ragwort, Senecio Jacobcea.

(2) Shepherd's Purse, Capsella Bursa-pastoris.

St. John BAptist Flower. Large-flowered St. John's Wort, Hypericum calycinum; often called Rr.SE OF SHARON (Stowey, near Clutton).

St. Patrick's Cabbage. London Pride, Saxifraga umbrosa.

St. Peter's Kexs. The Cowslip, Primula veris, is commonly called by this name in the neighbourhood of North Cheriton.

SALARY. A very common mispronunciation of Celery, Apium graveolens.

SAlet. Any plant used for salad, but most commonly applied in West Somerset to Mustard and Cress.

Salt Celluar. The Wood Sorrel, Oxalis Acetosella (Bourton, Dorset), from its acid flavour when eaten by children.

SammY Gussets. The Early Purple Orchis, Orchis mascula (Kilton). Compare GossIPS and SiNGle Gus.

SAND Flowers. Sea Pink or Thrift, Statice maritima (Portland).

SARAH Janes. The Red Campion, Lychnis dioica (Colyton).

SAss Apples (i.e., Sauce Apples). A kind of sharp apple (Trowbridge).

Satin Balls. A number of young people at Paulton give me this as a local name for the Heather, Calluna vulgaris. 
SATIN Flower. (1) The Greater Stitchwort Stellaria Holostea.

(2) Lunary or Honesty, Lunaria biennis, from the satiny dissepiments of its seed vessel.

Saturday's PFPPER. Sun Spurge, Euphorbia Helioscopia (Wilts : Eng. Plant Names).

SATurday Night's Pepper. Sun Spurge, as above (Wilts: "Village Miners ").

SAUCE ALONE. A very general name for the Garlic Treacle-mustard or Jack-by-the-hedge, Sisymbrium Alliaria. Mr. T. W. Cowan kindiy writes me: "Dr. Prior thinks it likely that the latter part of the compound represents Italian aglione, French alloignon = garlic ; so the word would mean 'garlic sauce.' Gerarde in his Herbal (1597, page 650) says: 'Sauce alone is joined with Garlick in name, not because it is like unto it in forme, but in smell; for if it be brused or stamped it smelleth altogether like Garlicke.'",

SCABBY HANDS. (1) The Cow-parsnip or Hogweed; Heracleum Sphondylium (Yeovil and Ubley).

(2) The Hemlock, Conium maculatum (Camerton and Keynsham).

(3) Several correspondents give me this as a local name for the "Hare's Parsley" or "Hair Parsley," by which may be meant Anthriscus sylvestris, or the Hemlock, as above. See HARE'S PARSLEY.

SCAB FLowErs. A school-girl at Gittisham. (Devon) gives me this as a local name for the Angelica.

SCABS. (1) Wild Parsley. Anthriscus sylvestris (Winscombe).

(2) Garlic Treacle-mustand or Jack-by-thehedge, Sisymbrium Alliaria (Melksham).

SCARLET LIGHTNING. (1) A corruption of Scarlet Lychnis, Lychnis chalcedonica. See FLOWER OF BRISTOWE.

(2) Red Spur Valerian, Kentranthus ruber (Shute, Devon).

SCARYBaEUS. The compilers of the Wiltshire Glossary say : "At Yatton Keynell the Figwort, Scrophularia, is so called by the old women. It is pounded up with lard and made into eyelotion. Our informant considers that the name is from some fan iful resemblance between the flower and the Scarabæus beetle. But it is more probably a variant of SQUARRIB (Square-rib, from the shape of the stem), which is the name in use among old people round Chippenham."

SCENT BOTTLES. The Head-master of Shoscombe Schools gives me this as a local name for the Hoary Plantain, Plantago media, and the Head-mistress of one of the Bridgwater Schools gives it as a local name for the fruits of the Plantain. 
SCENTED BUsh. The cultivated Lavender, Lavandula (Paulton).

SCENTED BUTTERCUP. Several young peorla in the Axminster district give me this as a local name for the Silverweed, Potentilla Anserina.

SCENTED DAIsIEs. School-girls at South Petherton give me this as a local name for the Tansy, Tanacetum vulgare, and the Camomile. By the latter name is probably meant the Stinking Camomile, Anthemis Cotula, although Dr. Watson tells me that during the past 20 years this plant has to a great extent been displaced in Somerset by Matricaria Chamomilla. The former plant is now much rarer than the latter, which is now the commonest Camomile in the county.

SCENTED FERN. The Tansy, Tanacetum vulgare (West Somerset and Devon).

Schoor BeLL. The Harebell, Campanula rotundifolia (N.-W. Wilts).

SCHOOL-BOY's CLOCK. A fairly general name for the Dandelion, Taraxacum officinale.

Scotch Gramfer Grigales. The Self-heal, Prunella vulgaris (Leigh, Dorset).

Scotchuren. Thistles of almost every kind.

Scoтch THIstre. A Watchet correspondent tells me that this name is given in that district to the Dwarf Thistle, Cnicus acaulis.

SCRUMPLING. A small apple which never arrives at perfection (West Somerset).

SeA Botrue. Different species of the Seawrack or Fucus, are called Sea-bottles, in consequence of the stalks having round or oval vescicles or pods in them. The pod itself. (Jennings.) Dr. Watson tells me that all the species of Fucus have the fertile pod-like branches. Bladders (for floating purposes) are present in Fucus versciculosus and Ascophyllum nodosum.

Sea Daisy, Sea Gilliflower, or Sea Pink. The 'Thrift or Sea Pink. Statice maritima.

SEARCH-IIGHT. Yellow Toadflax, Linaria vulgaris (Luxborough).

SEA-SPRAY. Rosemary, Rosmarinus officinalis.

SEAvES. In certain parts of England rushes are called Seaves, and this name was also given to the pith of rushes dipped in fat and used as candles. Holloway wys in Hamphire young onions art called Sives, probably from the stalks resembling those of rushes. Mr. Onions tells me SIvEs is an old form of CHIVEs dating back to the 15 th century.

SEGS. Holloway gives this as a Gloucestershire name for Sedge or Rushes. It is sometimes applied to the Yellow Iris, Iris Pseudacorus. The name comes from the A.S. $\operatorname{secg}=$ a small sword, and has reference to the shape of the leaves. 
Self-Heal. This is the genoral English name for Prunella vulgaris, but a number of schoolchildren at Brompton Regis apply it to the Common Bugle, Ajuga reptans.

Selareen. The House-leek, Sempervivum tectorum. "Sel " is a corruption of "sin," the Anglo-Saxon word for "ever" ; hence SELGREEN means " evergreen."

Sengreen. (1) Same as Selgreen.

(2) This name is sometimes applied to the Lesser Periwinkle, Vinca minor.

Senna PoDs. Common Centaury, Centaurium umbellatum; a plant very largely used in the past for its medicinal properties (Melbu'y Osmond).

SEven SIsters. A common name for the oldfashioned clustered small white roses.

SEVEN Years' Love. This is usually described as "a variety of everlasting flower." Mrs. Bray, in her "Borders of the Tamar and Tavy," speaks of "Seven Years' Love " as the name of a common flower in the West of Englana, but the Rev. H. Friend, who made a special study of the flower names of Devonshire, was unable to identify the plant. The Rev.H.N. Ellacombe (vizar of Bitton, 1870 ), said that he had often seen the country bridesmaids in Gloucestershire and other parts bringing the double-flowered Yarrow (Achillea ptarmica) to the hymeneal altar under this name.

SHACKLE BACKLE. Several school-girls at South Petherton give me this as a local name for the Bladder Campion, Silene latifolia.

SHACKLE BAGs. The Yellow Rattle, Rhinanthus Crista-galli.

SHACKLE BAskets. (1) Yellow Rattle, as above.

(2) Quaking Grass, Briza media, commonly called WAG-WANTS.

SHACKLE BOXEs. (1) Quaking Grass, Briza media.

(2) The Lousewort or Red Rattle, Pedicularis sylvatica (Stockland, Devon).

SHACKLE CAPS. Yellow Rattle, Rhinanthus Crista-galli (East Harptree).

SHACKLE Grass. Quaking Grass, Briza media.

SHACKIERS. (1) Yellow Rattle, Rhinanthus Crista-galli.

(2) The fruits of the Ash and Maple (Devon).

SHADEs of EvenING. The White Campion, Lychnis alba (North Petherton).

SHAGgy Jacks. The Ragged Robin, Lychnis Flos-cuculi (South Somerset and Devon).

SHAKE A BAsket. Doubtless a corruption of Shackue BAsket. Sent me by several Wincanton school-girls as a local name for the Quaking Grass, Briza media. 
SHAkers. A Wiltshire name for the Qualing Grass, as above.

SHAKING Grass. A common name in West Somerset and Devon for the Quaking Grass, Briza media.

SHALDER. (1) A broad, flat rush growing in ditches (Jennings). Rush, sedge, growing in ditches (Rev. W. P. Williams).

(2) Great Pendulous Sedge, Carex pendula (Butleigh: Rev. R. P. Murray).

(3) The Yellow Iris, Iris Pseudacorus (Lottisham).

SHAME-FACED MATDEN. (1) Wood Anemone, Anemone nemorosa. Recorded in "Sarum Diocesan Gazette " as used at Farley.

(2) The Star of Bethlehem, Omithogalum umbellatum (Shrewto:, Wilts).

Shame-Faces. The Pansy, Viola tricolor (a Martock school-boy).

SHAM HoNer Fuower. Ladies at Martock and North Petherton give me this as a local name for the Pyramid Orchis, Orchis pyramidalis.

Shamrock. Wood Sorrel, Oxalis Acetosella, or White Clover, Trifolium repens. The name is from the Irish seamrog, a diminutive of seamar= Trefoil. Considerable diflernce of opinion has long existed as to the particular plant to which the name rightly belongs. Dr. Watson writes me: "The name is given in Ireland to a number of plants with leaves divided into three leaflets. My experience inclicated that it was most frequently given to Trifolium dubium, probably because this is the most abundant plant with trifoliate leaves in most districts. In England the name is more commonly given to species of Oxalis." Mr. James Britten tells me he has gone into the matter very carefully, and it is quite certain that the Lesser Yellow Trefoil, Trifolium minus, is the true Shamrock. I believe $T$. dubium and $T$. minus are :eally one and the same plant. Dr. Watson therefore confirms Mr. Britten. In the particular district with which I am dealing the name appears to be given most frequently to the Wood sorrel.

SHAN'T BE LONG. A number of school-girls at South Petherton give me this as a lo:al name for the Deadly Nightshade, by which they probably mean the IVoody Nightshade, Solanum Dulcamara.

SHeeps' BeLLs. The Harebell, Campanula rotundifolia (Uplyme).

SHeEP's BrT. A general English name for the Annual Scabious, Jasione montana.

SheEps' EARs. The Woolly Woundwort, Stachys lanata (Over Stowey). More often called DONKEY'S EAR or MOUSE'S EAR.

SHeEp's Favourite Morsel. A Martock lady gives me this as a local name for the Plantain. 
SHEEP-SHEARING Flower. (1) The Iris (Brompton Regis).

(2) The Gladiolus (Bridgwater).

Sheep Shears. The Iris (Rodney Stoke and Litton). Sec above (1).

Sheeps' TaIls. (1) Catkins of the Hazel, Corylus Avellana; more often calied LAmB's 'TaIls or Pussy Cats' TaIls.

(2) Great Drooping Sedge, Carex pendula (Wincanton).

Sheep's Thistle. Creeping Plume Thistle, Cnicus arvensis (Wincanton).

Sheep's Thyare. Wild Thyme, Thymus Serpyllum (Stoke Abbo', Dorset). See SHEPHend's THYMIE (1).

SHEE SHACK. A form of SHICK SHACK (which see), used at Stoke-under-Ham.

SHekel Basket. The Yellow Rattle, Rhinanthus Crista-galli (Leig', Dorset). See SHACKLE BASKET.

Sheker Box. Yellow Rattle, as above (Melplash, Dorset). See SHackle Box.

SHensha. The Shumac Tree (Pulman).

Shepherd's Barometer. The Scarlet Pimpernel, Anagallis arvensis; more often called POOR MAN'S WEATHER-GLASS.

SHEPHERD'S CLOCK. (1) Scarlet Pimpernel, as above.

(2) The Dandelion, Taraxacum officinale (Minehead).

SHEPHERD'S CLUB. An old country name for the Great Mullein, Verbascum Thapsus.

SHEPHERD'S DELIGHT. (1) The Scarlet Pinapernel, Anagallis arvensis.

Mr. Elworthy says it is uncertain from the pronounciation whether delight or daylight is intended. See SHEPHERD's JoY.

(2) The Mealy Gueider Rose or Wayfaring Tree, Viburnum Lantana (Miss Elia Ford, Melplash).

(3) Wild Clematis or Traveller's Joy, Clematis Vitalba (a schoo-girl at Cnideock). Mallet).

SHePHerd's FrIENd. The Mountain Ash, Pyrus Aucuparia (Miss Ella Ford, Melplash).

SHePHERD's Joy. The Scarlet Pirapernel, Anagallis arvensis (Bridgwater). See SHePHERD's DELIGHT (1).

Shepherd's Pouch. Shepherd's Purse, Capsella Bursa-pastoris.

SHePherd's PURSe. (1) The general English name for Capsella Bursa-pastoris. It is some- 
times mis-applied to other plants, as for instance :-

(2) The Yellow Rattle, Rhinanthus Cristagalli (Winscombe and Dalwood).

(3) Bird's-foot Trefoil, Lotus corniculatus (Over Stowey).

(4) The Calceolaria (South Petherton and Luppitt).

(5) Lunary or Honesty, Lunaria biennis (Wells).

SHEPHERD's Rod (or StafF). The Teasel, both the Common and the Small Species, Dipsacus sylvestris and D. pilosus.

SHEPHERD's SCRIP. A Wincanton schoo-girl gives me this as a local name for the Shepner'a's Purse, Capsella Bursa pastoris.

SHePHerd's THYME. (1) Wild Thyme Thymus Serpyllum. See SHeEP's ThyME.

(2) In Wiltshire the Chalk Milkwort, Polygala calcarea. This plant is fairly common on the Wilts chalk downs, but is not likely to be distinguished from other Milkworts except by botanists.

SHEPHERD's WARning. The Scarlet Pimpernal, Anagallis arvensis.

SHEPHERD'S WEATHER-GLASS. The Scarlet Pimpernel, Anagallis arvensis, from its habit of closing its flowers before rain.

SHickle SHACkLes. Quaking Grass, Briza media (Stoke-under-Ham).

SHIck SHack or SHIg SHAg. The leaves and "apple" of the oak, worn by school-children and others of a larger growth, on May 29th, known throughout the district as "Oak-apple Day" or "Shick Shack Day" -this being supposed to be the day on which King Charles hid in the oak.

SHrurrngs. Lunary or Honesty, Lunaria biennis (Broadstone, Dorset).

SHIMmIES, SHIMMT-SHIRTS, or SHIMmies AND SHIRTs. (1) One or other of these names is used throughout a great part of Somerset, Dorset, and Wilts for the Greater Convolvulus or Hedge Bindweed, Calystegia sepium. See SHIRTs.

(2) In the neighbourhood of North Cheriton these names are given to the Greater Stitchwort, Stellaria Holostea.

SHIRT Butrons. (1) Flowers of the Greater Stitchwort, Stellaria Holostea.

(2) A school-girl at Oakhill gives this as a local name for the iWhite Campion, Lychnis alba.

SHIRTS or SHIRTS AND SHIMCMIES. Lesser Convolvulus or Field Bindweed, Convolvulus arvensis. See SHIMartes.

SHIT-ABED. The Dandelion, Taraxacum officinale (Wiltshire). 
Shrtsack. A Wincanton form of SHIck SHack.

ShIVErING Grass. Quaking Grass, Briza media.

ShIver Shakes. Quaking Grass, Briza media (a South Petherton school-girl).

SHTVERY SHAKES (or SHAKERIES), Quaking Grass, Briza media (North Somerset and Wilts).

SHoE Nut. When I was a boy this was a very common name for the Brazil nut, Bertholetia excelsa, on account of its shape and appearance.

Shoes and SuIPpers. The Wood Anemone, Anemone nemorosa (Pawlett).

SHoEs AND Socks. The Columbine, Aquilegia vulgaris.

Shoes And Stockings. (1) Bird's foot Trefoil, Lotus corniculatus.

(2) The Columbine, Aquilegia vulgaris.

(3) The White Dead Nettle, Lamium album (Frome).

(4) The Polvanthus.

(5) The Wild Pansy or Heartsease, Viola arvensis (Merriott).

(6) A school-girl at Higher Horton gives me this as a local name for the Lamb's Tongue Plantain, Plantago media.

Sickle Wort. (1) Self-heal, Prunella vulgaris, from the shape of its flowers, which seen in profile resemble a sickle.

(2) Common Bugie, Ajuga reptans. See CARPENTER'S HERB.

Silgreen. The House-leek, Sempervivum tectorum. See SELGREEN.

Silks ANd Satins. Honesty, Lunaria biennis.

Silky Flossy. A Wells lady gives me this as a local name for the Salpiglossis; apparently a corruption of, or play upon, the true name.

Silky Flotver. The blossom of the Pear, Pyrus communis (school-girls at Paulton).

SILVER BALL. Guelder Rose, Vibernum Opulus (Clevedon).

Silter Beils. (1) The double Guelder Rose of gardens (Cherhill, Wilts). More commonly called. SNowbaLLs.

(2) A school-girl at Paulton gives me this as a local name for the Wood Anemone, Anemone nemorosa.

SILver Dock. Miss M. J. Shute, late of Oare, gives me this as a local name for the Bistort, Polygonum Bistorta.

Sulver Leaves. (1) The Silver Weed, Potentilla Anserina.

(2) The Woolly Woundwort, Stachys lanata (a school-girl at Wellington). 
(3) Lunary or Honesty, Lunaria biennis (Wimborne).

Silver Pennies. Lunary or Honesty, Lunaria biennis.

Sruven SHekels. Quaking Grass, Briza media (Weston Zoyland).

Silver FErN. The Silver-weed, Potentilla Anserina, from its silvery fern-like foliage.

SILVER KNEw Nothing. The Head-Master of Shoscombe Schools gives me this as the commonest local name for the Scarlet Elf-cup Fungus, Geopyxis coccinea; and Miss Ida Roper tells me the same name is used at Clutton. This Fungus is often called in Somerset SoldiERs' CAPS or Jerusalem Stars. See Silver Sixpences.

Silver-Leaved Tree. (1] The Silver Birch Betula alba (school-children at Paulton).

(2) The Abele or White Poplar, Populus alba, (West Somerset).

Silver Sixpences. The Scarlet Elf-cup Fungus, Geopyxis coccinea (school-children at Mells). See Silver IN NEW Nothing.

SHVER SuIPpers. Nigella damascena, commonly known as LovE-IN-A-MIST or DEVII-IN-ABUSH (Litton).

SIMPLER's JoY. An old name for the Vervain, Verbena officinalis, which I gather from a schoolboy at Martock is still sometimes used in that district.

Single Castle. His Honour J. S. Udal gives this as a local name at Portland for both the Early Purple Orchis, O. mascula, and the Greenwinged Orchis, O. morio.

Single GHost. The Early Purple Orchis, O. mascula (Crewkerne, East Lambrook, and Trowbridge).

SIngle-guss. The Early Purple Orehis, $O$. mascula (Jennings, Rev. W. P. Williams, and Rev. J. Coleman).

Single Gussies. A correspondent of Somerset a id Dorset Notes a id Queries in 1893 gave this as an old name at Hinton St. George for the Bluevell, Scilla non-scripta.

SINGREEN. The Hotse-leek, Sempervivum tectorum. See SELGREEN.

SINNEGAR. A common name in Mid and East Somerset fot the Stock, Matthiola incana.

SrTHes or Sives. Chives; a kind of Garlic, Allium Schoenoprasum, used as a pot herb. Mr. F. W. Mathews describes it as a cultivated bulbous perennial with slender rush-like leaves, much less "tasty" than the ordinary Garlic, A. sativum. See Seaves. 
SkeGa. - An old English name for the Yollow Iris, Iris Pseudacorus.

Sketwer-TIMber (Tree or Wood). (1) The Spindle-tree, Euonymus europcus, from the fact that it is from the wood of this tree that butchers' skewers are made.

(2) The Dogwood, or Wild Comel, Cornus sanguinea. See note under SkIVEr-TIMBER.

SKIPPING Ropes. Main stems and large branches of 'Traveller's Joy, Clematis Vitalba (Bishopstone, Wilts).

SkIVER or SkIVver. The Wilts Glossary gives the latter form as the local name for the Dogwood, Cornus sanguinea, and states that it is so called because the wood of this tree is used for making skewers. See note under SkIVERTIMBBER.

SkIver Berries. Fruit of the Spindle-tree, Euonymus europceus (Stalbridge).

SkIver-TIMrer (or Wood). (1) The Spindletree, Euonymus europceus, from the fact that butchers' skewers (called in Somerset "skivers ") are made from the wood of this tree. Mr. F. T. Elworthy, referring to the statement that skewers are made from Dogwood, says: "I cannot admit it. The exact contrary is the fact. Butchers all say 'Dog-timber stinks wo'se-n a dog-tidn fit vor skivers : t'll spwoil the mate.' Butchers' skewers are made of SKIVER-TIMBER, Euonymus europceus, and when buying them of gypsies or others, they are careful to smell them, because the appearance of the wood is alike." I learn from Mir. T. W. Cowan that Cormus sanguinea, Euonymus europaus, Rhamnus Frangula, and Viburnum Opulus are all callea Dogwood.

(2) Notwithstanding Mr. Elworthy's opinion quoted above, this name is frequently applied to the Dogwood or Wild Cornel, Cornus sanguinea, from which skewers are apparently frequently made. See SkIVER.

SKY SCRAPER. A Yeovil school-boy gives mo this as a local name for the Sunflower, Helianthus annures.

SLeEping Beadty. A Dorset name for the Wood Sorrel, Oxalis Acetosella.

SleEpy Clover. The Wood Sorrel, Oxalis Acetosella (Puddletown, Dorset).

SleEpy-HEAD. (1) Common Red Poppy, Papaver Rhoeas (Dowlish Wake).

(2) Yellow Goat's-beard, Tragopogon pratense (Bradford-on-'Tone). Often called JACK-GO-ToBED-AT-NooN, from its habit of closing up its flowers about mid-day.

SLIPPER-FLOWER. The Calceolaria. 
SLIPPER SLOPPERS. Meadow Vetchling, Lathyrus pratensis (East Dorset).

Sloe Bush. Mr. W. S. Price, of Wellington' writes me:- "In this neighbourhood it is curious that in autumn the Black-thorn is always referred to as a Sloe-bush, and I believe many young people for this reason fail to identify the two as the same plant."

Sloes, Slones, or Sloos. The fruit of the Black-thorn, Prunus spinosa. Dr. R. C. Knight writes me: "My father was always emphatic on the point that the SLOE was the large variety and the SNAG the small. As a matter of fact, there is probably every gradation of fruit, from the size of a wren's egg to that of a blackbird's egg-all within Prunus spinosa. The fruit expert here (Research Station, East Malling, Kent) informs me that in Kent the larger ones are called SLOES and the smaller ScADs. Hampshire people call the smaller HEDGEPICKS." This view is confirmed by the compilers of the Wiltshire Glossary, who say that in South Wilts, about Salisbury, the large fruit is known as SLOES or SLuES, and the small as SNAGS. See also Sloom. Dr. Downes writes "There is probably some confusion between the Sloe and the Bullace, Prunus insititia, the latter being common in Somerset, and bearing much larger fruit."

Stoo. See Sloes.

Stoon. The School-mistress at Barrington gives me "Sloom-blossom" as the local name for the flowers of the "Wild Plum," which bears a sweet fruit, and "Snag-blossom "for the "Wild Damson," which bears a bitter fruit. See SLOES. Dr. Watson suggests that the "Vild Plum " here referred to may be Prunus domestica, which occurs wild in many places.

SLONE-BLoOM. Blossom of the Black-thorn, Prunus spinosa.

Sirallage or Siralledge. A general English name for the Wild Celery, Apium graveolens.

Sirall AND PretTies. Virginia Stock, Malcolmia maritima (Compton, near Yeovil). More generally called LitThy AND PRETTY.

Sitall Clover. Several school-children at Brompton Regis give me this as a local name for the Black Medick, Medicago lupulina, but Dr. Watson tells me it is more likely that the Small Yellow Trefoil, Trifolium duibium, is intended. Most people would confuse the two plants, and in fact even botanists sometimes do so.

Sirart-Ass (or ARSE). A very common name in West Somerset for the Water Pepper, Polygonum Hydropiper. See ARSE-SMART.

Shell Foxes: A school-girl at Oakhill gives 
me this curious name for the Wood Anemone, Anemone nemorosa.

Smocks. Greater Convolvulus or Hedge Bindweed, Calystegia sepium.

SMokING CANE. The dried porous stalks of the Traveller's Joy or " Old Man's Beard," Clematis Vitalba, which boys use for smoking. The dried rootlets of the elm serve the same purpose.

SMUT. A pernicious black fungus which attacks the ears and stalks of corn, mostly wheat, after a cold spring. Very common (F. T'. Eiworthy). Dr. Watson gives me as the scientific name of Smut, Ustilago carbo, which is an aggregate name for the several species (U. Tritici, $U$. Hordei, U. Avence, \&c.) infesting corn.

SNAG. (1) The fruit of the Black-thorn, Prunus spinosa; a corruption of Anglo-Saxon Slag. Rev. Wm. Barnes (Dorset) defines it as "the fruit of a species of Black-thorn, smaller than Sloes." See SLoEs.

(2) The stump of a tree when cut off above the ground or hedge. The word does not apply to the root, but only to the part above ground ( $\mathrm{F}$. T. Elworthy). Commonly applied to any tree stump or other obstacle preventing progress of a boat.

SNAG-BLooth or BLowth. The blossom of the Black-thorn, Prunus spinosa.

SNaggs. A number of school-children at Paulton give me this as a local name for the Bladder Campion, Silene latifolia.

SNAKE (or SNAKE's) Berries. A name applied to the bright red berries of a number of plants which are poisonous (or supposed to be so), particularly to those of the Wild Arum, Iris, Woody Nightshade, Bryony, \&c. See ADDER's FOOD and SNAKE'S FOOD.

SNAKE Fern. (1) The Common Hart'stongue, Phyllitis Scolopendrium (Somerset).

(2) The Bracken, Pteris aquilina (Sherborne and Deverill, Wilts).

SNAKE (or SNAKE'S) Flowter. A name applied in various parts of the district to a large number of different flowers, amongst them being the following :-

(1) Greater Stitchwort, Stellaria Holostea. I have heard children in the neighbourhood of Yeovil say that if you pick these flowers a snake will run (!) after you, and Dr. Downes tells me the same idea prevails about Ilminster, and in fact as far away as Cornwall.

(2) Several correspondents in Dorset apply the name to the Lesser Stitchwort, Stellaria graminea. 
(3) The Wood Anemone, Anemone nemorosa (South Somerset and Dorset).

(4) Both the Spotted Orchis, O. maculata, and the Early Purple Orchis, O. mascula.

(5) Broad-leaved Garlic, Allium ursinum (Somerset and Dorset).

(6) Several correspondents in different parts of Somerset apply this name to the Bittersweet, and others to the Deadly Nightshade; probably all of them mean the Woody Nightshade (or Bittersweet), Solanum Dulcamara.

(7) Dog's Mercury, Mercurialis perennis (Brompton Regis and Milborne St. Andrew).

(8) The Herb Robert, Geranium Robertianum (Fivehead and Butleigh).

(9) Wild Hyacinth or Bluebell, Scilla nonscripla (Babcary and Dalwood).

(10) Meadow Saffron or Autumn Crocus, Colchicum autumnale (Shepton Mallet).

(11) Field Scabious, Scabiosa arvensis (Barrington).

(12) Greater Convolvulus or Hedge Bindweed, Calystegia sepium (school-girls at Paulton).

(13) The Ragged Robin, Lychnis Flos-cuculi (a school-girl at Axbridge).

(14) Shepherd's Purse, Capsella.Bursa-pastoris (Lydford-on-the-Fosse).

(15) In Wilts, the Black Mullein, Verbascum nigrum. In parts of S.W. Wilts children are cautioned not to gither this plant, because a snake may be hiding under the leaves.

SNake Lteaves. Ferns (Rev. W. P. Williams). Mor'e especially the Hart's-tongue, Phyllitis Scolopendrium.

SNAKE PIPE. The Great Horse-tail, Equisetum maximum (North Somerset; White's Bristol Flora). Since this list has been in type a farmer stated in the Weils Bankruptcy Court that he had lost a number of cows through their eating Snake-pipe, which brought on "screw."

Snake Plant. Broad-leaved Garlic, Allium ursinum (Ilminster).

SNAKE VIOLET. Several correspondents in Dorset give me this as a lecal name for the Dog Violet, Viola canina, and the Wood Violet, V. sylvestris.

SNAKES AND ADDERS. (1) The Wood Anemone, Anemone nemorosa (a school-girl at Winsham).

(2) The Bøe Orchis, Ophrys apifera (a schoolgirl at Chideock).

SNAKes AND LADDERs. The Foxglove, Digitalis purpurea (a school-girl at Castle Cary).

SNAKE's ChERries. Fruits of the Dogriood or Wild Cornel, Cornus sanguinea (Staple Fitzpaine.)

SNAKE'S FooD. The red berries of a number of 
nlants which are poisonous, or supposed to be poisonous; particularly those of :-

(1) The Wild Arum or Cuckoo-pint, Arum maculatum.

(2) The Stinking Iris, Iris foetidissima.

(3) The Black Bryony, Tamus comminis.

(4) Woody Nightshade or Bittersweet, Solanum Dulcamara. "Snake's Food" is a variation of ADDER's Foon (which see), which is a corruption of the Anglo Saxon attar - poison.

(5) Broad-leaved Garlic, Allium ursinum (Stratton-on-the-Fosse).

(6) The Butterbur, Petasites ovatus (schoolboys at Axbridge).

(7) Comfrey, Symphytum officinale (a schoolgirl at Wincanton).

(8) Dog's Mercury, Mercurialis perennis (Okeford Fitzpaine, Dorset).

(9) Yellow Toadflax, Linaria vulgaris (Stickland, Dorset).

SNAKE's Foot. The School-mistress at Babcary gives me this as a local name for the "Dragon-wort," which is an old name for the Bistort or Snake-weed, Polygonum Bistorta.

SNAKE'S GRAss. Common Yarrow or Milfoil, Achillea Millefolium (Iwerne Minster, Dorset).

SNAKE's HEAD. (1) A general name for the Common Fritillary, Fritillaria Meleagris.

(2) The Common Tormentil, Potentilla erecta (S.W. Wilts).

SNAKES' MEAT. (1) Mr. W. S. Price (TVellington) writes: "SNAKES' IEAT is more often used in this locality than ADDERS' Food to designate poisonous beries, and is specially used for the berries of the Bryony or the seeds of the Arum." It is also applied to the other berries mentioned under SNAKE's FOOD.

(2) A correspondent at South Molton gives me this as a local name for the Self-heal, Prunella vulgaris.

(3) Cow-parsnip or Hog-weed, Heracleum Sphondylium (school-children at Alfington, Devon).

SNAKE'S RHUBARB. A Dorset name for

(1) The Butterbur, Petasites ovatus.

(2) The Burdock, Arctium minus. SNAKE's Victuars. Cuckoo-pint, "Arum
maculatum (Evershot, and Wilts: "Great Estate," ch. 2).

SNAKE TONGUE. The Hart's-tongue Fern, Phyllitis Scolopendrium (Upottery, Devon).

SNAKE-IVEED. (1) A general English name for the Common Bistort, Polygonum Bistorta.

(2) Common Knot-grass, Polygonum aviculare (Allerford).

(3) The Greater Stitchwort, Stellaria Holostea (Wincauton). 
(4) Goose-grass or Cleavers, Galium Aparine (Nettlecombe).

(5) Black Bryony, Tamus communis (Stockland, Devon).

SNAPDRAgoN. (1) The usual English name for Antirrhinum majus.

(2) Frequently misapplied to the Yellow Toadflax, Linaria vulgaris.

(3) Less often applied to the Iry-leaved Toadflax, Linaria Cymbalaria.

(4) 'The Rev. H. Friend gives this as a Devonshire name for the Foxgleve, Digitalis purpurea, for which it is also sent me from Stoke St. Gregory, Wincanton, and Oakhill.

(5) In North Devon the Columbine, Aquilegia vulgaris, is known by many people only under the name of SNAPDRAGON.

SNAP-JACKS. (1) A very common name throughout the greater part of the district for the Greater Stitchwort, Stellaria Holostea, in consequence, I believe, of the way in which children "snap" the seed capsules, but the name may also have reference to the brittleness of the stalfs, which "snap" very quickly if the plant is roughly handled, and earned for it the old name of ALL-BONES, which is practically the English equivalent of the specific name Holostea.

(2) The name is less frequently applied to the Snapdragon, Antirrhinum majus.

(3) From Yeovil and Minehead I have this se at me as a local name for the Yellow Toadflax, Iinaria vulgaris.

(4) Miy Watchet correspondent, in whom I have confidence, gives this as a local name for both the White Campion, Lychnis alba, and the Bladder Campion, Silene latifolia. The fo mer is confirmed by a school-girl at Misterton.

(5) The Herb Robert, Geranium Robertianum (Wiveliscombe).

(6) The Foxglove, Digitalis purpurea (Bridg water).

(7) A Crewkerne school girl gives it as a local name for the Scarlet Pimpernel, Anagallis arvensis.

SNAPS. (1) A common name in West Somerset for the Foxglove, Digitalis purpurea.

(2) The Greater Stitchwort, Stellaria Holostea (S.W. Wilts).

SNEEZE WORT. The Sneeze-wort Yarrow, Achillea Ptarmica. When dried the plant excites sncezing, and it is said that the Highlanders use it as a sebstitute for snuff.

SNITCH-BACKs. The school-mistress at Beaminster gives me this as a local name for the Cyclamen.

SNoTs. The herries of the Yew, Taxus baccata; doubtless from their slimy rulp. As a boy in East Somerset I never heard the Yew-berry called by any other name. 
SNOTTER-BERRIES. (1) Yew-ber ries (Shoscumue).

(2) Mr. W. S. Price (Wellington) tells me the name is also given in that district to the Snowberry, Symphoricarpus racemosus.

SNotTer GaLLs. Yew-berries (Wilts).

SNotTy GoBbles. Yew-borries (Yeovil and Stoke-under-tiam).

SNotty Gogs. Yew-berries (Donhead, Wilts).

SNow BALLS. (1) A very common name throughout the district for the Guelder Rose, Viburn'm Opulus, particularly the double variety.

(2) The Snow-berry, Symphoricarpus racemosus

SNow-BELLs. The Snowdrop, Galanthus nivalis.

SNow CARpet. Sweet Alyssum, Alyssum maritimum (Evercreech and Beaminster). Mr. Jas. Britten suggest $s$ that probably Arabis alpina was madnt.

SNOWFLAKE. (1) The general English name for Leucojum astivum, the Summer Snowflake, and $L$. vernum, the Spring Snowflake. They are rarely found wild, but the former species has escaped and spread in certain locailities near Taunton and Wellington.

(2) The flower of the Hawthorn or May, Cratogus monogyna (South Petherton).

(3) The Star of Bethlehem, Ornithogalum umbellatum.

(4) Mr. Edward Vivian, of Trowbridge, gives this as a local name for the Guelder Rose, Viburnum Opulus.

SNow IN HARVEST (or IN SUMMER). (1) The garden plant, Arabis alpina; more often called SNOW ON THE MOUNTAIN.

(2) Cerastium tomentosum, A garden species of Mouse-ear Chickweed. Both 1 and 2 are sometimes called WHITE Rock.

(3) Less frequently applied to the White (or Sweet) Alyssum, Alyssum maritimum.

(4) "Snow in Harvest" is an old country name for the Wild Clematis or Traveller's Joy, Clematis Vitalba: a lady at Martock sends it to me as being still used in that district.

SNow on THE ModntaIN: (1) Most generally applied to the garden plant Arabis alpina.

(2) A garden species of Mouse-ear Chiskweed, Cerastium tomentosum.

(3) White (or Sweet) Alyssum, Alyssum maritimum.

(4) White Meadow Saxifrage, Saxifraga granulata (S.W. Wilts).

(5) A correspondent at Shrewton (Wilts) gives me this as a local name for the Greater Stitchwort, Stellaria Holostea.

SNow PIercer. The Snowdrop, nivalis (Chard and Ilminster district). 
SNow Toss. The Guelder Rose, Vibumum Opulus.

Snuff-Box. A Puff-ball fungus, Lycoperdon, when fully ripe and giving off its spores when touched.

SnufF CANdiE. Yellow Dead-Nettle, Lamium Galeobdolon (Calne, Wilts).

SoApleaves. A correspondent at Batcombe gives me this as a local name for the Water F'igwort, Scrophularia aquatica, and says that if rubbed between the hands the leaves produce a lather not unlike that of soap, but Dr. Watson tells me the soapiness of the Figwort is very slight, and suggests my correspondent has possibly confused the plant with the Soapwort, Saponaria officinalis. See GIPSY'S SOAP.

SOD-APPLE. Great Hary Willow Herb Epilobium hirsutum, from its apple-like smell when crushed (N.W. Wilts).

SOJER. His Honour J. S. Udal gives this as a Dorset name for the Military Orchis, Orchis militaris. See SOLDIER.

Sowder Boys. Red Spur Valerian, Kentranthus ruber (Mr. W. C. Baker, late of Maunsel).

SoldiERs. A name given to a number of different plants, but apparently most commonly in this district to

(1) The stems and seed-heads of the Lamb'stongue Plantain. Plantago lanceolata. Children gather these and make them fight until the head of one or the other is knocked off. See Cock's HEADS and Fighting Cocks.

(2) A fairly common name for the Red Poppy, Papaver Rhoeas. A Wiltshire correspondent wrote me some years ago : "A field of these is supposed to resemble an army of 'Red-coats.' The name survives in spite of a khaki army."

(3) The name is given, particularly in Dorset, to several species of Orchis. (See SoJER.) A number of my Dorset correspondents apply it to the Early Purple Orchis, O. mascula; a few to the Spotted Orchis, $O$. maculata (including one at Winsham), and a correspondent at Charmouth applies it to the Bee Orchis, Ophrys apifera.

(4) The Foxglove, Digitalis purpurea (Dorset).

(5) Wild Arum or Cuckoo-pint, Arum maculatum (Wincanton).

(6) The Herb Robert, Geranium Robertianum (Devon).

(7) Common Sorrel, Rumex Acetosa (Martock), doubtless from the reddish colour of its stems, petals, and sepals.

(8) Crimson Clover, Trifolium incarnatum (Taunton).

(9) A school-boy at Furley gives this as a. local name for the Mat-grass, Nardus stricta. 
Soldiers AÑ ANGels. A school-girl at Dalwood (Devon) gives this as a local name for the Wild Arum or Cuckoo-pint, Arum maculatum, possibly through confusion with DEvILS AND ANGELS or SOLDIERS AND SAILORS.

Soldiers AND SAILors. (1) The Wild Arum or Cuckoo-pint, Arum maculatum (Milborne Port, Oakhill, and Mucbelney).

(2) Common Lungwort, Pulmonaria officinalis, on account of its red and blue flowers.

(3) Yellow Iris, Iris Pseudacorus (Wimborne district).

(4) A school-boy at Furley gives this as a local name for the Sundew, Drosera, but it is not easy to see the reason.

Soldiers' Buttons. A name given to a number of different plants, but most genetally throughout this district to

(1) The March Marigold, Caltha palustris.

(2) The burs of the Buraock, Arctium minus.

(3) Buttercups of various kinds, particularly the Acrid Crowfort, Ranunculus acris.

(4) The Field Szabious, Scabiosa arvensis.

(5) Correspondents at Hatch Beauchamp and Nettlecombe give this as a losal name for the Yellow Water Lily, Nymphoea lutea.

(6). From several different parts of Wiltshire this is sent me as a local name for the Water Avens, Geum rivale.

(7) The Scarlet Elf-cup Fungus, Geopyxis coccinea; more often called SolDIER's CAP.

(8) The Hawkbit, Leontodon hispidum, or L. autumnale (Sexey's School).

(9) The Rock-rose, Helianthemum Chamocistus (Shoscombe).

(10) The Wood Anemone, Anemone nemorosa (Timberscombe).

(11) A school-girl at Winsham, who sends an excellent list of local names, includes this as a local name for the Self-heal, Prunella vulgaris. (Tisbury).

(12) Wild Columbine, Aquilegia vulgaris

SOLDIER's CAP. (1) The Scarlet Elf-cup Fungus, Geopyxis coccinea

(2) The Early Purple Orchis, Orchis mascula (Yarcombe).

Soldier's Cross. The Wallflower, Cheiranthus Cheiri (Ilminster).

SOLDIER's FEATHERS. Love - lies-kleeding, Amaranthus caudatus or $A$. melancholicus.

Soldier's Hat. The Scarlet Elf-cup Fungus (East Somerset), more often called SoLDIER'S CAP.

Soldiers' JACkets. Miss Ida Roper gives me this as a Dorset name for the Early Purple Orchis, O. mascula.

SOLDIERS-SAILORS-TINEER-TAILORS. Common 
Rye-grass, Lolium perenne (S.W. Wilts). See Does My Mother WANT Me? and Love Me, LOVE Me Not (2).

Solemn BeLLs of Sodom. Common Fritillary or Snake's Head, Fritillaria Meleagris (Rampisham, Dorset). See Drooping and Mournfur BeLL OF SodoM.

SoI OMON's SEAL. The general English name for Polygonatum multiflorim.

SON BEFORE THE FATHER. An old country name for the Great Hairy Willow Herb, Epilobium hirsutum, because as Lyte explained long a.go, "The long husks in which the seede is contained do come forthe and waxe great before that the floure openeth." The only correspondent who has sent me this name as still being used in the district is Mrs. Day, of North Petherton.

Sops IN WINE. The Clove Pink or Carnation, Dianthus Caryophyllus, from its flowers being used to flavour wine. Chaucer wrote :-

" And many a clove gilofre

And note muge to put in ale,

Whether it be moist or stale."

The name was also given to a smaller kind of single Gilliflower or Pink. A Bradford-on-Tone school-boy gives it as a local name for the Pink, and several correspondents in different parts of the county as a local name for "Jiloffers."

SORCERER's VIOLET. An old country name for the Lesser Periwinkle, Vinca minor.

Sour Dock, Dog, or DUCk. Common Sorrel, Rumex Acetosa. Eaten by children.

Sour Grabs. (1) Common Sorrel, as above.

(2) The Crab Apple, Pyrus malus.

Sour Leaves. Common Sorrel, Rumex Acetosa (Shoscombe).

Sour SALLY. The Wood Sorrel, Oxalis Acetosella (Muchelney).

Sour SAP. Wood Sorrel, as above (Shute, Devon).

Sour Treforl. A Taunton correspondent gives me this as a local name for the Wood Sorrel, Oxalis Acetosella.

Sow-BANe. Mr. J. W. White, in his "Bristol Flora," gives this as a lical name for the Nettleleaved Gonsfoot, Chenopodium murale.

Sow Flower. Sow Thistle, Sonchus oleraceus (N.W. Wilts).

Sow's EARs. Broad-leaved Saxifrage (? Saxifraga crassifolia or umbrosa) (Ilton).

SPALLIARD. An espalier-trained fruit tree.

Spar (or Sparrow) Grass. Asparagus. 
Sparked Grass. Variegated Grass, also called LADY'S GARTERS, Phalaris arundinacea (S.W. Wilts, Somerset border). Dr. Watson suggests the grass intended is much more likely to be $P$. canariensis.

SPARKed Holm. A variegated form of Holly, Ilex aquifolium.

SPARKed LAorel. Variegated Laurel, Aucuba japonica.

SparRow BIrds. The Herb Robert, Geranium Robertianum (West Somerset). The late Mr. F. T. Elworthy quotes a man as saying : "We calls 'em Sparrow-birds, but the proper name's Arb Rabbits."

Sparrow Grass. A corruption of Asparagus. Mr. T. W. Cowan tells me that in bis " Book about Roses" Dean Hole states that upon one occasion being asked to adjudicate at a rustic flower show on the merits of certain classes of wild ferns and grasses, amongst the latter he observed three cases of Asparagus being exhibited. Upon his saying to the exhibitors that this was not contemplated by the schedule, his ignorance was at once enlightene 1-" Please, sir, it says ferns and grasses, and this is sparrow grass."

SPEAK, SPEEK, or SPEKE. (1) Lavender, Lavandula Spica.

(2) Several correspondents apply the name to the Rosemary, Rosmarinus officinalis.

Spear. (1) A kind of thick rush (G. Sweetman).

(2) Pampas Grass, Gynerium argenteum (a Crewkerne school-girl).

SpeArs. The stems of the Reed, Arundo Phragmites, sometimes employed instead of laths to hold plaster (Rev. W. Barnes). The name of this Reed in the London Catalogue is Phragmites communis.

Spear Thistle. Spear Plume Thistle, Cnicus lanceolatus.

SPEEDTELL. The general English name for the genus Veronica, of which the best known and most popular is probably the Germander Speedwell or BrRD's-EYE, V. Chamaedrys. Dr. Prior attributes the name to the way in which the coroila falls off and flies away as soon as it is gathered; "Speedwell" being equivalent to "Fare-rvell," "Good-bye," and a common form of valediction in old times. "Forget-me-not," a name that has since passed t $)$ a Myosotis, appears to have first been given to this plant and addressed to its fleeting flowers. Compare BrEAk-BAsIN.

SPICK. (1) Lavender, Lavandula Spica.

(2) A Reed (Phragmites communis), formerly used instead of laths for plastering (Geo. Sweetman). 
SPIDER IN HIs Web. The Fennel-flower or Love in a Mist, Nigella damascena (Hatch Beauchamp). See SPIDER's W EB. (1).

SpIDER Plant. The pot plant, Saxifraga sarmentosa, known also as Mother of THOUsANDS, Aaron's BeARD, Stratwberry Plant, and by many other popular names. The young plants as they hang on their runners over the sides of the flower-pot have a sufficient resemblance to spiders on their web to suggest this homely name.

SPIDER's WeB. (1) The Fennel-flower or Love-in-a-Mist, Nigella damascena (Winfrith, Dorset). See SPIDER IN HIS Web.

(2) A lady at Barrington gives me this as the local name for a plant "like a thistle-bush, bearing yellow flowers, something like Golden Chain." Is it possible she means the Common Furze? Dr. Watson knows no other plant found in the neighbourhood of Barrington to which her description applies.

SpIDERWOrT. (1) Any species of Tradescantia. (2) The Fennel-flower, Nigella damascena. (Ilton). See SPIDER's WEB (1).

SPIKE. Lavender, Lavandula Spica.

SPIKENARD. (1) Mr. F. W. Mathews, of Bradford-on-Tone, gives me this as a local name for the Common Centaury, Centaurium umbellatum.

(2) Sweet Vernal-grass, Anthoxanthum odoratum (N.W. Wilts).

(3) Lavender, Lavandula Spica (N.W. Wilts occasionally).

SPIKY FLowers. A number of school-children at Paulton give me this as a local name for the Bittercress, Cardamine hirsuta.

SPINE.-Turf grass taken up in slabs for $\mathrm{re}^{-}$ laying.

Spinning Jenny. The Maple, Acer campestre (a school-boy at Bradford-on-Tone), presumably from the way in which its winged seeds spin in their flight through the air.

SPotTed DoG. Early Purple Orchis, Orchis mascula (Hatch Beauchamp).

SpRING Caller. The Crocus (Miss Ella Ford, Melplash).

SPRING FLOWER. (1) A fairly general name throughout the district for the Polyanthus.

(2) A correspondent at Chettle (Dorset) gives this as a local name for the Herb Robert, Geranium Robertianum.

Spring Messenger. The Lesser Celandine Ranunculus Ficaria (Shaftesbu:y district).

SPUDs. A name frequently applied to Potatoes , possibly first introduced $b_{J}$ Irish harvesters. 
SQDARRIB. The Figwort, Scrophularia (Wilts). See Scarybaeus.

SQUEAKERS. Water Figwort, Scrophularia aquatica (Axminster district). See FIDDLES.

SQUEEZE-JAws. Yellow Toadflax, Linaria vulgaris (Kilton).

SQUINANCY-WORT. A common English name for the Small Woodruff Asperula cynanchica; common in the northern part of Somerset. Sometimes called QUINSY WORT in consequence of its former use in disorders of the throat.

SQUIRTERS. The Snow-berry, Symphoricarpus racemosus (a Long Sutton school-girl).

SQuтTCH. Couch-grass, Agropyron repens (Edington). See QUTTCH.

StAgger WorT or StAVER-WORT. The Common Ragwort, Senecio Jacoboe. I am indebted to Mr. T. W. Cowan for the fo'lowing quotation from Gerart's Herball, p219 (1579) :- "This plant is called in Latine Herba S. Jacobi, or S. Jacobi flor, and Jacobea ; in French Fleur de $S$. Jacque; in Enslish S. James his woort; the country people do call it Stagger woort ind Stauerwoort, and also Raguoorte."

Stag's Horn Moss. Common Club Moss, Lycopodium clavatum. It grows plentifully on Dunkery and many other of our hills.

Statnless Bay. Several school-girls at South Petherton give me this as a local name for the Laurel, Laurus nobilis.

STANDING GUSSETS. Early Purple Orchis, Orchis mascula (Axbridge).

STAR. (1) Several school-children at Otterhampton give me this as a local name for the Daisy, Bellis perennis. Wilts).

(2) Greater Stitchwort, Stellaria Holostea (N.W.

STARCH-worT. Wild Arum or Cuckoo-pint, Arum maculatum, from its tubers yielding the finest starch for the large collars worn in Queen Elizabeth's reign.

STAR-FLOWER. A name applied to a number of different flowers which have their petals arranged more or less in the shape of the conventional "star."

(1) Frequently applied to members of the Stitchwort and Chickweed family, the genus "Stellaria, of which the scientific name means "starlike."

(2) To members of the Aster family, including the Michaelmas Daisy. The generic name Aster means "a star," and members of the family are
often called STARWORTS.

(3) Several of my correspondents apply the name to the Lesser Celandine, Ranunculus Ficaria. 
(4) Biting Stonecrop, Sedum acre (Staple Fitzpaine).

(5) Common Tormentil, Potentilla erecta (Barford, Wilts).

(6) Wood Loosestrife, Lysimachia nemorum (Barford, Wilts).

Starlight. (1) Lesser Celandine, Ranunculus Ficaria (Crewkerne).

(2) I have heard this name applied to the Herb Robert, Geranium Robertianum, by children in Yeovil and Mudford.

Star of Bethlehex. (1) The usual Englis $h$ name for Ornithogalum umbellatum; the name is said to be due to the resemblance of the white star-like flowers to the pictures of the star that announced the birth of Christ.

(2) A common name throughout a great part of the district for the Greater Stitshwomt, Stellaria Holostea.

(3) Wood Anemone, Anemone nemorosa (East Somerset).

(4) Scarlet Pi npernel, Anagallis arvensis (a Wincanton school-girl).

(5) Correspondents at Canerto 1 and Willand (Devon) apply the name to the St. John's Wort, Hypericum.

(6) Frequently applied to the greenhouse Cineraria.

(7) A Taunton so:respondent gives this as a local name for the Passion-flower, Passiflora carulea.

Star of the Wood. Correspondents at

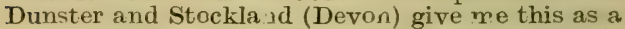
[o al name for the Greater Stitchwort, Stellaria Holostea.

StARry Exes. The Star of Bethlehem, Ornithogalum umbellatum (Stalbridge).

Stars. (i) The Herb Robert, Geranium Robertianum (school-girls at South Petherton). See STAR-LIGHT.

(2) Lilac, Syringa vulgaris (a school-boy at Thorne St. Margaret).

(3) Clustered Bell-flower, Campanula glomerata (N.W. Wilts).

(4) The Cineraria (South Petherton).

Star Thistle. (1) The true Star Thistle is Centaurea Calcitrapa, which is very rare in Somerset.

(2) The name is commonly applind in the Wincanton district to the Marsh Plume Thistle, Cnicus palustris.

(3) Several schjol-childrea at Dunster give it as a local name for the Knapweed, Centaurea.

Starwort. (1) Any plant of the genus Aster, which in lude; the Michaelmas Daisg.

(2) Any plant of the genus Stellaria, wbich includes the Stitchworts and Chickweeds. 
Strations. Mr. F. W. Mathews gives me this as an "appnoximate abbreviation" of the name Nasturtiun, as used in West Sorerset. Very frequently pronounced STURTIONS.

StAVESACRE. An old English name for a tall Larkspur of Southern Europe, Delphinium Staphysagria. Dr. Prior (1870) speaks of it as " a plant that was once in great use for destroying lice, but which with the gradual increase of cleanly habits is become scarce in our gardens." "Stavesacre" is generally said to be a corruption of the Latin name Staphysagria, which in its turn is a corruption of the Greeb name, which meant "a wild raisin."

Star-PLodgh. The Rest-harrow, Ononis repens.

Step-Mothers. (1) The Wild Pansy or Heartsease, Viola arvensis.

(2) A correspondent, who I believe was formerly a school-mistress somewhere in the neighbourhood of Stogarsey, gives this as a Ircal name for the Stitchwort, Stellaria Holostea.

STERChen or Stershen. A common corruption of the name Nasturtium.

Stewed Gooseberries. A correspondent at Okeford Fitzpaine gives me this as a local name for the Soapwort, Saponaria officinalis. (? Is this a mistake due to confusion with the Willow Herb? ' See Gooseberry Pre.)

Stick Butrons. (1) Goose-grass or Cleavers. Gali'm Aparine (Watchet).

(2) The Burdock, Arctium minus (Watchet).

STrcK Donkey. Goose-grass or Cleavers. Galium Aparine (North Somerset).

StICKkrs. Burs of the Burdock, Arctium minus ('Thorncombe).

Strcky BAcks. (1) Dr. R. C. Knight gives me this as a local name for the fruits of the Goose-grass, Galium Aparine. Also of

(2) The Burdock, Arctium minus; I have tinis also from school-children at Axbridge and Widworthy (Devou).

(3) Several school-children at Axbridge apply the name to the Sundew, Drosera rotundifolia.

Sticky (or Strcking) BAtus. (1) The fruits of the Burdock, Arctium minus (South Petherton and Upottery).

(2) Fruits of the Goose-grass or Cleavers, Galium Aparine (Paulton).

StICKY BUDS. Common Hound's-tongue, Cynoglossum officinale (Symondsbuly and Wootton Fitzpinine, Dorset).

Sticky Buttons. Fruits of the Burdock, Arctium minus (Devon). 
StICKY J JACKS. Fruits of the Burdock, as above (Evercreech).

Sticky Tree. A dozen school-children at Paulton give me this as a local name for the Fir, by which I assume they mean the Scots Pine, Pinus sylvestris.

Sting Netrle. A common name for the Great Nettle, Urtica dioica; frequently applied also to the Small Nettle, U. urens.

Sting-Nettle Flower. Several school-children at Bradford-on-Tone give me this as a local name for the Bugle, Ajuga reptans. Dr. Watson describes this as "a very bad case of confusion worse confounded."

Stingr-wingies. Yellow Dead Nettle, Lamium Galeobdolon (Leigh, Dorset).

Stink Daisies. Common Fever-few, Chrysanthemum Parthenium (Stoke-under-Ham).

Stinker BoBs. The Herb Robert, Geranium Robertianum (Evercreech).

Stink Flowers. (1) The Herb Robert, Geranium Robertianum (Stoke-under-Ham).

(2) Common Hemlock, Conium maculatum (a Taunton correspondent).

Stink-horn or Stintring Polecat. A common fungus, Phallus impudicus, growing in old hedgerows and elsewhere, resembling a horn in shape and emitting a foatid smell like carrion. Also Phallus fatidus.

Stinking Bobs. The Herb Robert, Geranium Robertianum.

Stinking Jenny. (1) The Herb Robert, as above.

(2) A school-boy at Bradford-on-Tone gives this as a local name for the Garlic, Allium ursinum.

Stinking Lities. Garlic, Allium ursinum (Dunster).

Stink LILIES. A Stalbridge correspondent gives me this as a local name for the Crown Imperial, Fritillaria imperialis.

Stock GILLY-FLower. The Wallflower, Cheiranthus Cheiri (Queen Camel).

Stockings AND SHozs. (1) The Birds-foot Trefoil, Lotus corniculatus; more often called Shoes AND Stockings.

(2) The Columbine, Aquilegia vulgaris (a Muchelney school-boy).

Stone Weed. (1) Mr. F. W. Mathews (Bradford-on-Tone) and Mr. Edward Vivian (Trowbridge) give me this as a local name for the Persicaria, Polygonum Persicaria. 
(2) Mr. T. W. Cowan tells me that in Suffolk the name STONE-WEed is given to the Knotgrass, Polygonum aviculare, and he thinks it probable that it is really to this plant, and not to the Persicaria, that the name is applied in this district.

SToRks. The Herb Robert, Geranium Robertianum (Leigh, Dorset). See STORK's BrLL.

SToRk's BrLL. This is the general English name for plants of the genus Erodium, but correspondents in several parts of the district give it as a local name for the Herb Robert, Geranium Robertianum, which is a Crdne's-bill. See Storks.

StORY OF THE CROSS. The Passion-flower, Passiflora carulea (Camerton).

Story-telifers. The Barren Strawberry, Potentilla sterilis (school-children at Thorne St. Margaret).

Strangle-WEed. (1) Any plant of the Dodder family, Cuscuta.

(2) Any plant of the Broomrape family, Orobanche.

(3) The Greater Convolvulus, Calystegia sepium (Dowlish Wake).

STRAP-GRASS. Couch-grass, Agropyron repens (Wareham).

Strawberry Geranium. The old-fashioned pot-plant Saxifraga sarmentosa, because its runn rs and shoots are like those of a strawberry; it was formerly so commonly grown in cottage windows as to be called the Poor MAN's GERANIUM. See Aaron's BEARD (2).

Strawberry Plant. (1) The Wild Strawberry, Fragaria vesca.

(2) The Barren Strawberry, Potentilla sterilis (Devon).

(3) Same as Strawberry Geranidm.

Stratwberry SAXIFrage. Same as StrawBERRY GERANIUM.

Strawberry Tree. Arbutus Unedo; so called from the colour and shape of its fruit. Barnes).

Stratr-Mote. A stalk of grass (Rev. Wm.

STRIAL. Couch-grass, Agropyron repens (Wareham). See Strow.

STRIKE. Yellow Toad-flax, Linaria vulgaris (Miss Ella Ford, Melplash).

String Foy. "Wild Clover" (Minchead school-girls).

STRIP FOR STRIP. Wild Succory oi Chicory, Cichorium Intybus (a South Petherton schoolgirl). 
StrIP JACK NAKED. Autumn Crocus or Meadow Saffron, Colchicum autumnale. (A schoolgirl at Dalwood, Devon).

STRoIL. Couch-grass, Agropyron repens. The late Mr. F. T. Elworthy says "particulariy applied to the white tube-like roots whicb are turned up by the plough. See Stram.

STUBBARd. An early codling appie; one of the commonest of favourite eating cupples.

STuBwort. An oid nome for the Wood Sorrel, Oxalis Acetosella, having reference to its growth about the stubs of trees; sent me by correspondents a.t Watchet and Taunton as still being used locally.

Sturtion. A very common corruption of the name Nasturti:m, Tropcolum majus.

SUCK APPLE. - A well-known variety of Apple; red, hard, and crisp-eating. Sometimes called QUARRENER, QUARRENDEN, Or QUARANTINE (Mr. W. S. Price, Weilington).

Suck Botrle. White Dead Nettle, Lamium album. See HONEY-SUCKLE (4).

Suckers. Common Comfrey, Symphytum officinale (Shoscombe). See SWEET SUCKERS.

Suckie SuE. White Dead Nettle, Lamium album.

SUCKLES. A contracted form of the name Honeysuckle, Lonicera Periclymenum, sent me by school-children at Winsham.

Sucky Calves. Wild Arum or Cackoo-pint, Arum maculatum (school-cnildren at Sampford Arundel).

SUGAR. A correspondent at Storvey (near Clutton) gives me this as a local name for "Green Dock," and TEA as a local name for " Red Dock."

Sugar Basins. (1) Two scbool-girls at Ilminster give me this as a local name for the Greater Stitchwort, Stellaria Holostea.

(2) School-children in several districts give this as a local name for Buttercups.

Sugar Busses. The Red Clover, Trifolinm pratense (school-children at Otterhampton). Sae HONEY-SUCKLE (2).

Sugar Candy. Both the tender shoots and the fruits (hips) of the Wild Rose, Rosa canina (Donhead, Wilts). I have heard this name given to the young shoots of the Wild Rose, by schoolchildren in East Somerset.

SUgAR-COdLins. Great Hairy Willow Herb, Epilobium hirsutum (N.W. Wilts). More generally called CODLINS AND CREAMr.

Sugar Leaves. Young leaves of the Elm, Ulmus campestris (Bridgwater). 
SUMMRER (or SUMMER's) FAREWELL. (1) A name generally given to several species of Aster, popularly known as the Michaelmas Daisy. See FAREWELL SUMMER (1).

(2) Several correspondents in West Som rset, and still more in East Devon, apply this name to the Phlox. See Fareivel Summer (2).

(3) Several school-children in the neighbourhood of Axminster and Uplyme give me this as a local name for the Meadow-sweet, Spircea Ulmaria.

Summer-Hats. The Pansy, Viola tricolor (school-children at Bathealton).

Sunmer Poppy. Common Red Poppy, Papaver Rhocas (Watchet).

Sunmer Rose. The Rev. H. Friend gives this as a Somerset name for the Corchorus (or Kerria) japonica; a shrub which bears orangecoloured blossoms.

SuMMER SAdcers. White Campion, Lychnis alba (a school-boy at Evercreech).

Sun Bonnets. The Daffodil, Narcissus PseudoNarcissus.

SUNFLotver. (1) The general English name for Helianthus anmuus.

(2) A name often given to the Common Rockrose, Helianthemum vulgare.

(3) A school-girl at 'Thorne St. Margaret gives it as a local name for the Marigold, Calendula officinalis, and Mr. W. S. Price, of Wellington, confirms this use of the name. This is interesting in view of Shak :speare's reference in his "Winter's Tale" (iv., 3) to

"The Mrarigold that goes to bed with the sun And with him :ises weeping."

(4) The Rev. H. Friend gives this as a Devonshire name for the Star of Bethlehem, Ornithogalum umbellatum.

Sungreen. A Wiltshire form of Sengreen or Silgreen, an old name for the Houseleek, Sempervivum tectorum.

SUNSETS. A correspondent at Camerton gives me this as a local name for the Tree Millow, Lavatera.

Sun's ExE. 'The Sunflowe1, Helianthus annuus (school-girls at Nettlecombe).

SUN-SHADES. (1) A common name for the Lesser Convolvulus or Bindweed, Convolvulus arvensis.

(2) The Wall Pennywort, Cotyledon UmbilicusVeneris (a school-girl at Dunster).

(3) The School-Mistress at Beaminster gives me this as a local name for the Sunfluwer, Helianthus, annurs. 
SUn's RAYs. The Sunflower, Helianthus annuus (a school-girl at Chilson, Chard).

Swallow Pears. Services: Sorb Apples, the fruit of Pyrus torminalis.

Swallow-wort. (1) The Greater Celandine, Chelidonium majus. D1. Prior says: "The scientific name Chelidonium is from the Greek word fo: a swallow, and the plant may gat its name of Swallow-wort either from the faet that it blossoms at the season of tne swallows' arrival and withers at its departure, or from the old balief recorded by Aristotle and others that the swallows used this plant to restore the eyesight of their soung ones, even if their eyes were put out."

(2) The Lesser Celandine, Ranunculus Ficaria.

The name is also applied to a number of other plants, but I have no further records of its use locally.

SwaMr's Companion. A Hardington Mandeville school-boy gives me this as a local name for the Cuckoo-flower or Lady's Smock, Cardamine pratensis.

Swan Amongst the Flowers. Correspondents at Trowbridge and Charminster (Dorset) give me this as a local name for the White WaterLily, Castalia alba.

Swan-BILL. The Yellow Iris, Iris Pseudacorus (Hatch Beauchamp). See Duck's BILLs.

Sweers. (1) The Fennel-flower or Love-ina-Mist, Nigella damascena (Yeovil).

(2) The Great Reed-mace, Typha latifolia, more often called Bulrush (9. school-boy at Malls).

(3) The Large-flowered St. John's Wort, Hypericum calycinum (Farley, Wilts).

SweEp's Brush. (1) Hoary Plantain, Plantago media (East Somerset).

(2) Ribwort Plantain, Plantago lanceolata (East Somerset).

(3) The Colt foot, Tussilago Farfara (Mells).

(4) A correspondeat at Donhead (Wilts) gives me this as a local name for the "Cornflower," by which I think she frobably means the Blark (or Lesser) K napweed, Centaurea nigra. See CHIMNEY SweEP (4) and ChinNey Sweep's Brush (2).

(5) Common 'Teasel, Dipsacus sylvestris (Rev. H. Friend).

SWEET ALICE (or ALISON). Alyssum maritimum, a plant with the smell of honey; "Alice" or "Alison" is a corruption of the name Alyssum, and is no: the name of a pretty lady.

SwEET BeTsies. (1) A double form of the White Saxifrage, Saxifraga hypnoidcs.

(2) The late Mr. F.'T. Elworthy says this rame is occasionally used in West Somerset for Dicentra spectabilis. 
Sweet Betsy (or Betty). Red Spur Valerian, Kentranthus ruber (Axbridge and Chettle, Dorset).

SweEt Chestnut. The usual name for Castanea vesca, to distinguish it from the Horsechestnut, Essculus Hippocastanum, which is very bitter.

Sweet Hay. Meadow Sweet, Spircea Ulmaria (Ohettle, Dorset). See New Mown HAY (2).

SWEET SUCKERs. Comfrey, Symphytum officinale (Horton). See SuckERS.

SWEeTHEARTS. (1) Burs of the Goose-grass or Cleavers, Galium Aparine, from the way in. which they stick to one's clothes. Names 2, 3. and 4 are all given for the same reasoa.

(2) Burs of the Burdock, Arctium minus.

(3) The Woodruff, Asperula odorata.

(4) Agrimony, Agrimonia Eupatoria (Mid and East Somerset).

(5) The Twayblade, Listera ovata (Staple Fitzpaine).

(6) Great Mr-1lein, Verbascum Thapsus (Culmhead).

(7) The Wild Arum or Cuckoo-rint, Arum maculatum (Stogursey).

(8) Greater Stitchwort, Stellaria Holostea (school-children at Oakhill).

SweET NANCY. (1) Greater Stitchwort, Stellaria Holostea (Castle Cary district).

(2) Narcissus (Crewkerne district). Mr. T. W. Cowan gives me the name of the particular species as Narcissus biflorus $f l$. $p l$.

Sweet Nut. See Sweet Chestnut.

SweET Nuts. Common Yarrow or Milfoil, Achillea Millefolium (Leigh, Drrset).

SweET SuckLe. Honey-suckle or Woodbine, Lonicera Periclymenum (Stoke-ander-Ham).

SwrEt SUltav. The general English name for the garden plant Centaurea moschata.

Sweet Thomas. The Nar sissus (Luxborough).

SwINE's Cress. (1) A general English name for Coronopus procumbens. Known also as Wart-cress, but Dr. Watson tells me the latter name is better restricted to the other British species of Coronopus, C. didymus.

(2) Common Nipplewort, Lapsana communis.

Swine's Grass. Common Knotgrass, Polygonum aviculare.

SwINE's SNout. The Dandelion, Taraxacum officinale, from the form of its receptacle.

Sword Grass. (1) A coarse Marsh Grass, Glyceria aquatica, often called DAGGERS or W TTHERS.

(2) MIr. T. W. Cowan tells me this is a enmmon name for the Striped Ribbon Grass, Phalaris 
arunäinacea. Sometimes called LADY's (or GARDENER's) Garters.

Sword Lriy. (1) The Gladiolus.

(2) The Yellow Iris, Iris Pseudacorus.

SwORD OF SPRING. The garden Crocus (Hatch Beauchamp).

Swords. The Yellow Iris, Iris Pseudacorus; in some distrists applied more particularly to the leaves.

Swords AND Spears. The Ribwort Plantain, Plantago lanceolata (Parkstone).

TAACHY. Fungus on trees (Wincanton).

Tables AND Chatrs. Seeds of the Box, Buxus sempervirens (Stoke-under-Ham and Muchelney). See Chatrs and TABT ES.

TACKER Grass. Common Knot-grass, Polygonum aviculare. It is said to owe its name te its toughness having suggested a likeness to a "tacker" or shoemaker's wax-end.

TACker WEed. Shefherd's Purse, Capsella Bursa-pastoris (sihos]-children at Conke St. Nicholas).

TAgers. A school-girl at Bradford-on-Tone gives me this as a local name for Marigolds. This may possibly ba a corruption of Tagetes, the generiz name of the French and African Marigolds, particularly in view of the fact that Mr. 'I'. W. Cowan tells me that he once had as gardener a Devonshire man who called the Dwarf Marigold (Tagetes signata pumila) TAGES, while all others he designated as "Marigolds." On the other hand, Mr. F. W. Mathews tells me he has heard the Marigold called TArgets, and he attributed the name to an evident similarity to the targets of archery practice.

TARE. (1) The Hairy Vetch, Vicia hirsuta.

(2) Greater Bindweed, Calystegia sepium (Wilts).

(3) Losser Bindweed, Convolvulus arvensis (Wilts).

TARGETs.-The Marigold (Bradford-on-Tone). See TAGETs.

I AP VETCH (i.e., Tare Vetch). (1) Common Vetch, Vicia cracca(Win

(2) A species of Tare, Ervum, that ocsurs among the corn, and in wet weather weighs it down (His Honour J. S. Udal, Dorset).

TASseL-FLower. The usual English name for an ornamental garuen annual of the Aster family, Cacalia cocrinea or Emilia flamma.

TAssels. (1) The flowers of the Ash, Fraxinus excelsior (a school-girl at Cbilson).

(2) Dr. Watson gives me this as a corrupted form of Teazel. 
TATEY. A common suntrastion of the name Potato.

TEA. The flower of the Sorrel or Sour-doci, Rumex Acetosa (Bridgwater and Stowey, near. Clutton). See Sugar.

TEA-CUPs. Butterzans, Ranunculus (Hatch Beauchamp).

TEA-FLower. (1) The Meadow Sweet, Spircea Ulmaria (Stoke-under-Ha.m).

(2) Elder Blossom, Sambucus nigra (South Petherton and Fivehead).

(3) Broad-leaved Willow-herb, Epilobium montanum (Leigh, Dor set).

Tea Plant. (1) An old lady living at Mudford tells me that she has always known the Common Agrimony, Agrimonia Eupatoria, by this name and by no other. In her younger days all the tea she drank was made from it. Anne Pratt says "The Agrimony is an ingredient in most of the herb-teas which have from time to time been recommended to public notice." Mr. F. W. Mathews tells me that an old resident of Blackmore, West Buckland, would never take any other "tea," and attributed her long life and great vigour to the ase of this her favourite beverage.

(2) Lycium chinense; often cultivated in cottage gardens as a hedge plant; ivell established in Somerset. Dr. Downes tells me that the name is due to the fact that the plant was sent to the Duke of Argyll in mistake for the real Tea Plant, owing to the labels having got accidentally changed.

Tear Your Mother's Eyes Odt. A lady at Exmouth gives me thi " as a local name for the Germander Speedwell, Veronica Chamodrys. See BIRD's EYE (1).

TEASER. The Nodding (or. Musk) Thistle Carduus nutans (Batcomk:e).

TEDDIES. Potatoes; a corruption of the contra?tion TATIES.

Teddy Butrons. The Fiela Scabious, Scabioza arvensis (Stoke-under-Ham).

TELU (THE) TIME. The Dandelion, Taraxacum officinale.

TEN o'Clock. The Star of Bethlehem. Ornithogalum umbellatum (a school-girl at Drayrott). See ELEVEN o'ClOCK LADY.

'Tens o' Thousands. Virginian Stosk, Malcolmia maritima (Trowbridge).

Tetrer Berries. The fruits of the Wnite (or Red-be:ried) Bryony, Bryonia dioica. An old English name for the plant was TETTERwORT.

Thatch. A Vetch of almost any species. Cultivated Vetches are almost invariably sporen of as Thatches. 
The Apostufs. The Star of Bethlehem, Ornithogalum umbellatum (Thorne St. Margaret).

The Ten Commandments. The Passionflower, Passiflora carulea (Puddletown, Dorset).

The Twelve Disciples. The Passion-flower, as above (Staple Fitzpaine).

THE VIRGIN's MாK. Several school-children at Th orne St. Margaret give me this as a local name for the "Milk Thistle," by which they probably mean one of the Sow Thistles, Sonchus, as the true Milk Thistle or Virgin Mary's Thistle, Silybum Marianum, is exceedingly rare in Somerset.

ThтмвLе - Flowfr. (1) The Foxglove, Digitalis purpurea, particuları in South Somerset and Dorset.

(2) Several srecies of Bell-flower, Campanula.

ThminLes. (1) The flowers of the Foxglove, Digitalis purpurea.

(2) The Harebell, Campanula rotundifolia.

(3) The Columbine, Aquilegia vulgaris (Pilton).

(4) A Yeovil school-boy applies this name to the Bird'c-foot Trefoil, Lotus corniculatus.

THINK of ME ALWAYs. Forget-me-not, Myosotis (school children at Thorne St. Margaret)

THorough-WAx. An old name for the Common Hare' - -ear, Bupleurum rotundifolium Dr Prior sa, s the name of Thorow-wax or Throw-wax. was given to the plant by Turner (1548) tecause "the stalke waxth throwe the leaues." Mr. Onions tells me Turner copied the German durchwachs (= through grow).

THOUSAND LEAF. Common Yarrow or Milfoil Achillea Millefolium. The names Milfoil and Millefolium both mean "thousand leaf." Mr. T. W. Cowan tells me that in many places this plant is called THOUSAND SEAT.

Thodsand Stars. A Martock school-boy gives me this as a local name for the Michaelmas Daisy.

THREAD Flowers. The Hemp Agrimony, Eupatorium cannabinum (an Ilminster schoolgirl).

Three Faces UNDER A Hood. The Pansy, both cultivated, Viola tricolor, and wild, $V$. arvensis.

THREe-Fingered JACK. The Ruc-leaved Saxifiage, Saxifraga tridactylites (White's Bristol Flora). The name tridactylites means "threefingered."

Throat Wort. A name given to a number of different plants which were formerly believed from the throat-jike shape of their Howers to crure diseases of the throat. The name is sent me by several correspondents for 
(1) The Foxglove, Digitalis purpurea.

(2) The Figwort, S'crcphularia.

(3) Several species of Bell-flower, Campanula.

(4) Blue Throat-wort, Trachelium coruleum.

Thumbs AND FINGers. (1) Common Furze, Vlex europous (Wells).

(2) Bird's-foot Trefoil, Lotus corniculatus (Dorset); more generally called FINGERS AND THUMBS.

Thunder-Bolt. The Rev. H. Friend gives this as a Devonshire name for the Red Poppy, Papaver Rhoas. See THunder-FLowER (1).

THUNDER DAIsy. Ox-eye Daisy, Chrysanthemum Leucanthemum. The Rev. Hilderic Friend says: "In Somersetshire the Horse-daisy or Ox-eye is devoted to the Thunder god, a curious circumstance when considered in connection with another fact-viz., that acorns are there called Jove's Nuts. Now we all know that the Oak is emphatically Jove's tree, but how is it that in Somersetshire these two names, not to mention others bearing on ancient religion and mythology, hve on when they have died out, or never existed, in other parts of England?"

THUNDER Flower. (1) The Red Poppy, "Papaver Rhoos (Ilton and Wiltshire). Cassell's "Wild Flowers as they Grow," speaking of the Poppy, says : "Sometimes it has been known as 'Thunder Flower' or 'Lightning Flower,' from a very curious superstition among children that if they pick it and the petals fall off, as they are apt to do, the children are then liable to be struck by lightning."

(2) Several correspondents in the neigbbourhood of Blandford give me this as a local name for the Ox-eye Daisy, Chrysanthemum Leucanthemum, more commonly called THUNDER DAISY.

THUNDER PLANT. The Houseleek, Sempervivum tectorum, from an old belief that if planted upon the roof it would protect the house from lightning.

TICKLERS (or TICKLING ToMmes). The rough seeds contained in the Hips or fruit of the Dog-rose. The name is due to the use made of them by boys, who take out the seeds which the fruit contains and put them down the back of another boy, where they tickle intolerably. Dr. Watson writes: "These so-called seeds are really the true fruits. The red portion of the Hip is formed from the Calyx-tube, which encloses the true fruits."

Tigen's Mouth. The Snap-dragon, Antirrhinum majus.

Tram-FLower (or TIAE-Teller). The Dandelion, Taraxacum officinale.

Trмотнч. The Common Cat's-tail Grass,
Phleum pratense. 
TIN KER-TATLOR GRAss. (1) Ribwort Plantain, Plantago lanceolata. So called from a game which girls of the better class play with it, striking the heads together and at each klow saying in succession, "li ker, tailor, soldier, sailor, gentleman, apot becary, ploughboy, thief." The blow which $\mathrm{kn}$ nocks the head off marks the one of these $\mathrm{p}^{\text {no- }}$ fessions which is to be that of the futare nusband. See CoCk-Grass and Soldiers.

(2) Penential Rye-grass or Eaver, Lolium perenne, also used by girls to discover the occupations of their future husbands. See Cock-Grass and Does Mr Mother WANT ME.

(3) Fescue-grass, Festuca, used for the same puirpose (Watchet).

TIPsy, Tipsy Leaves, or Tipsy Plant. Common Tutsan (St. John's Wort), Hypericum Androscemum (West Somerset and East Devon). Writing me some months ago with regard to my note under Bible Leaf (1), Mr. F. W. Mathews said: "The BIBLE LEAF of the list recently is designated TIPSY LEAves in the western Blackdowns; the name being evidently a corruption of Tutsan (S. John's Wort). Children thereabout place the leaves in their Bibles on account of the pleasing perfume of the dried sprays."

Tistr-Tosty. (1) The ball-shaped flower of the Guelder-rose, Viburnum Opulus.

(2) A ball made by stringing together the flowers of the Cowslips to amuse children; hence sometimes given to the Cowslip itself.

(3) The name is sometimes given to the flowers of the "Yellow Rose," Corchorus (or Kerria) japonica, because of their fancied resemblance to a "tisty-tosty" of cowslips.

Trssum. Tutsan (St. John's Wort), Hypericum Androsamum. The popular name is said to be a corruption of the French toute saine, meaning "All-heal," in consequence of the plart having been formerly largely used as a healing balm for wounds.

TITTY-Botrues. The Hips or fruits of the Wild Rose, Rosa canina (Shoscombe).

TOADs' CHEEsE. Toadstools (Ackerman, Wilts).

ToADs' HEADs. Snake's-head Fritillary, Fritillaria Meleagris (N.W.Wilts, English Plant Names).

Toads' MEAT. 'Toadstools.

'ToAds' MouTH. Snake's Fioad, Fritillaria Meleagris (N.W. Wilts).

TOM POT (PUTT or PUD). The name of a wellknowa apple, excellent for dumplings.

Tom Thumbs. (1) A very general name in this district for the Bird's-foot Trefoil, Lotus cornic'latus.

(2) Several school-children at Bradford-on- 
Tone and Sampford Arundel give this as a local name for the Hop Trefoil, Trifolium procumbens.

Ton Thunrs's Fingers and Thumbs. Bird'sfoot Trefoil Lotus corniculatus.

TOM THUMB's HoNEYSUCKLE. Bird's-foot Trefoil, Lotus corniculatus (S.W. Wilts Sarum Diocesan Gazette).

Tом (or ToMnry) TICKLERs. The Hips or fruit of the Wild Rose. Sse Trcklers.

Top KNot. The Black Knapweed, Centaurea nigra (Winsham).

Tossy Balus. Dr. Downes tells me that the cultivated double variety of the Guelder Rose, Viburnum Opulus, is always known by this name in Ilminster. It has also been sent me by a number of young people living in that district.

TOTTER-Grass. Quaking grass, Briza media (Stoke-under-Ham).

Touch ME Noт. (1) The Yellow Balsam, Impatiens Noli-tangere, and the Garden Balsam, I. Balsamina, from the well-known way in which their seed-vessels curl up their valves spirally at the slightest touch, jerking their contents into the face of the person bending over them.

(2) Mr. F. W. Mathews (Bradford-on-Tone) gives me this as a local name for the Thale-cress or Wall-cress, Sisymbrium Thalianum.

(3) The Burdock, Arctium minus (school-boys at Muchelney).

Towers. The Spotted Orshis, Orchis maculata (an Evercreech school-boy).

TOWN WEED. Dog's Mercury, Mercurialis perennis (West Moors, Dorset). Dr. Watson writes: "M. annua may perhaps be the species meant. The name fits it much better as it often occupies cleared spaces in urban districts. $M$. perennis is a much more rural plant."

Travellen's Comfort. Goose-grass, Galium Aparine (Deverill, Wilts).

Traveller's EASE. Common Yarrow, Achillea Millefolium (Little Langford, Wilts).

TRAVELLER's JoY. A very general name for the Wild Clematis, Clematis Vitalba, first given to it by John Gerarde (1597). Mr. T. W. Cowan writes me:-“This presents a curious instance of a word originating in a mistaken etymology. Lat. viburnum: shortened in the French name to viorne. This Latinized into viorna was taken by Gerard to mean vi(am)-ornaus, the plant which decks the road with its flowers, and so cheers the traveller on his way, and Englished "Traveller's Joy." He says " is called commonly Viorna quasi vias ornaus, of decking and adorning waies and hedges, where people trauell, and thereupon I have named it the Traueilers Joie." Gerarde, Herball p. 739 . 
Traveller's Rest. Tansy, Tanacetum vulgare. The leaves are supposed to cure blistered feet (Wilts, Diogenes' Sandals, p. 98).

Treacle Dabs. Dr. Watson tells me that he has heard this name applied in Somerset to the Field Wood-rush, Luzula campestris, but only by north-country people. It is sometimes called CHIMINEY SweEps in Somerset, and when I was a boy at Castle Cary I often heard it called ZuLUFLowER - a corruption of the generic name.

TrEeE. A well-informed correspondent at Watchet gives me this as a local name for the Common Mallow, Malva sylvestris.

Tree Mioss. Lichens, especially Usneas.

Trefoy or Tree-Foy. Trifolium. The variety of Clover which is sown annually.

TrIVET. A common mis-pronunciation of the name Privet, in the Barrington district.

Truckies of Cheese. The Common Nallow, Malva sylvestris (Sexey's S hhool). See CHEEsES.

True-Love or True-Love-Knot. The Herb Paris, Paris quadrifolia. Mr. T. W. Cowan kindly sends me the following quotation from Gerarde's Herball, p. 328 :- “ Herbe Paris riseth up with one small tender stalke two handes high, at the very top whereof come foorth fower leaues directly set one against another, in maner of a Burgunnion crosse or a true love knot; for which cause among the auncients it hath beene called herbe Trueloue."

Trunpet Cups. The Monkey Flower, Mimulus Langsdorfii (a school-girl at Thorne St. Margaret)

TrunPeT Flowers. The Greater Convolvi lus or Bindweed, Calystegia sepium (Wellington aistrict).

Truaret LIry. The Arum Lily (Wembdon)。

Trumpets. (1) The Greater Convolvulus or Bindweed, Calystegia sepium.

(2) The Indian Cress, Tropoolum, commonly called Nasturtium (Paulton and Symondsbury).

(3) The Fuchsia (Camerton).

(4) The Daffodil (Evershot).

TUCKer-Grass. Common Knot-grass, Polygonum aviculare (West Somerset). See TACKERGrass.

TUlP Tree. The Sycamore, Acer Pseudoplatanus; the smell or taste of the young shoots is supposed by children to resemble that of the Tulip (S.W. Wilts).

TUNFOOT. Several school-girls in the neighbourhood of Chard give me this as a local name for the Ground IVy, Nepeta hederacea. See TUNHOOF. 
TuNHOOF. An old English name for the Ground Iry, Nepeta hederacea.

TURBAN. A school-girl at East Mark gives me this as a losal name for the Tulip. If she is correct, it is very interesting, as our dictionaries trace the name Tulip through the French, Italian, and Turkish to the Persian dulband-a turban, and state that the Tulip is so named becajse the gay colours and the form of its flower suggest those of some turbans. Gerarde says: "After it hath beene some fewe days flowred the points and brims of the flower turne backward, l:k. a Dalmatian or Turkes cap, called Tulipan, Tolipan, Turban, and Turfan, whereof it took his name." Herball, p. 117.

TURBAN BELL. A correspondent living near Sherborne gives me this as a local name for the Fennel-flower, or Devil-in-the-bush, Nigella damascena.

TURKEY RHUBARB. (1) The Burdock. Arctium.

(2) The Butter-bur, Petasites ovatus.

TURKEX's Food. Goose-grass or Cleavers, Galium Aparine (Winsham district).

TURKEY's SNout. Love-lies-bleeding, Amarantus caudatus.

TURK's CAP. The Martagon Lily, Lilium Martagon.

TURK's HEAD. A correspondent at Burnhom gives this as a lozal name for the Tiger Lily, Lilium tigrinum.

TURMUT. A mis-pronunciation of Turnip; very common throughout the district.

TURNSOLE. A name applied to several plants which are supposed to turn their flowers towards the sua; particularly the Heliotrope, the Sunflower, and the Sun-spurge.

TURTLE Doves. (1) The Monk's-hood, Aconitum Napellus (Sampford Arundel and Horton).

(2) The Foxglove, Digitalis purpurea (a schoolgirl at Thorne St. Margaret).

Tusheroons. Mr. Edward Vivian, of Trowbridge, gives me this as a local name for nonedible fungi. He writes: "I have never seen the word printed and do not know its derivation, but it is very common colloquially."

TUTSAN. The general English name for a shrubby species of St. John's Wort, Hyperic ' $m$ Androscemum. The name is derived from the French tout saine, meaning All-heal, in consequence of the esteem in which it was formerly held as a cure for wounds. 
Tutries. The flowers of the Morello Cherry, Prunus Cerasus (Dorset).

Tutry Peas. Several school children at East Mark give me this as a local name for the Sweet Pea, Lathyrus odoratus. "I'tty" is used in the Somerset and Dorset dialect for a nosegay.

Tuzzy Muzzy. Fruit of the Burdock, Arctium minus (Wilts). Miss M. J. Shute tells me the name is also used in Devon.

Twelve Disciples. The Daisy, Bellis perennis (a school-girl at Chewton Mendip).

TWELVE O'Clocks. (1) A common name for the Star of Bethlehem, Ornithogalum umbellatum. See ELEVEN o'ClOCK LADY.

(2) The seed heads of the Dandelion, by which children pretend to tell the time by counting the puffs of breath required to blow all the seeds away.

(3) The Yellow Goat's-beard or Jack-g3-tobed-at-noon, Tragopogon pratense.

(4) The Convolvulus (? Calystegia sepium) (Donyatt).

(5) The Scarlet Pimpernel, Anagallis arvensis (a school-boy at Winscombe).

TwINkIING (or TwINkLE) STAR. The Greater Stitchwort, Stellaria Holostea. (school-children at Paulton).

Twiny Legs. The Rev.H. Friend gives this as a Devonshire name for the Red Bartsia, Bartsia Odontites.

TwITch. Couch-grass, Agropyron repens (West Somerset).

ULLUM. (1) A mis-pronunciation of Elm, common over a great part of the district. Mr. T. W. Cowan writes :-Ulm-tree, an elm, in W ycliffe Isaiah xli., 19, is an assimilation to the Latin Olmus.

(2) The stalks of Peas, Beans, \&c., after the crop has been picked. A mispronunciation of Haulm.

Umbrella-Plant. The Butter-bur, Petasites ovatus.

Umbrelias. (1) The Greater Convolvulus, Calystegia sepium.

(2) The Wall Pennywort, Cotyledon UmbilicusVeneris.

(5) The Periwinkle, Vinca (Camerton).

(4) Flowers of the Elder, Sambucus nigra (school-children at Paulton).

(3) The Butter-bur, Petasites ovatus.

(6) The Water Plantain, Alisma Plantago, aquatica (a school-girl at Ilminster).

UMPLESCRUMP. Cow-parsnip or HogweedHeracleum Sphondylium (West Somerset). See LTMPER-SCRTMP. 
UNDER-GROOND IVY. (1) Ivy-leaved Toad, flax, Linaria Cymbalaria (Curry Mallet).

(2) Ground Ivy, Nepeta hederacea (Draycott).

UNDER-Ground NUT. Earth-nut, Conopodium majus.

UNDER-GROUND ROSES. His Honour J. S. Udal gives this as a Dorset name for the Double Pink Hepatica triloba.

UPSTART. The Meadow Saffron or Autumn Crocus, Colchicum autumnale, from the way in which its flowers start up suddenly from the ground without any sign of leaves.

Variegated NetTles. Mr. Edward Vivian gives me this as a name for "Cultivated indoor plants with a nettle-like leaf. They are quite stingless. Their leaves are found in a hundred shades of reds, browns, ytllows, and greens, irregularly and beautifully blotched." I presume he refers to the Coleus.

VASES. The Dove's-foot Crane's-bill, Geranium molle (a school-girl at Tatworth).

VeArns. Several correspondents send me this as a local name for Ferns generally, and for the Bracken, Pteris aquilina in particula". Mr. F. W. Mathews writes: "The word VearN (not pluralized but used generically) means only bracken cut for stock-bedding."

VELVET Dock. A school-girl at Brompton Regis gives me this as a local name for what e believe to be the Greater Mullein, Verbascum Thapsus.

VENUS' BASIN. The Teasel, Dipsacus sylvestris (a school-boy at Bradford-on-Tone). Other old English names for the plant are VExUs' BATH and Venus Cup. Dr. Downes writes me : "The leaves are connate, i.e., united at their bases and surrounding the stem, so as to form a basin. The plant feeds on the insects which are drowned in the water which collects in this basin-an example of an insectivorous plant."

Venus' Chariot Drawn by Two Doves. An old Erglish namc for the Monk's-hood, Aconitum Napellus.

VENUS' Conrs. An ld name, still frequently used, for the Shepherd's Neeale, Scandix PectenVeneris.

VENUS' FLY-Trap. The true Venus' Fly-trap is Dioncea muscipula, a Sundew found in the sandy bogs of Nosth and South Carolina; but I gather from several school-children at. Wembdon that the name is incorrectly used in that district for our English Sundew, Drosera rotundifolia.

VENUS IN HER CAR. The school-children at North Cheriton and Hniton give this name to the 
Water Figwort, Scrophularia aquatica, and also to one or more of the Dead-Nettles, Lamium.

VENUS' Looking-GLass. (1) A general name for the Corn Bellflower, Leqonsia hybrida.

(2) Honesty, Lunaria biennis (a school-boy at Martock).

VeTHER-Vo. Common Feverfew, Chrysanthemum Parthenium. See Feather-Few.

VIERns. Ferns. Mr. Elworthy says "Always. In speaking of VIERNS, gener?lly the ommon Bracken is meant, of which great quantities are cut for iedding."

VIoLiN Strings. Leaves of the Ribwort Plantain, Plantago lanceolata (Bridgwater). See Fiddle Strings (2).

VIRgIN MARry's MILK Drops. Mr. Edward Vivian (Trowbridge) gives me this as a local nome for a plant unknown to him personally, but said to have a white spotted leaf. He no doubt refer's to the Common Lungwort, Pulmonaria officinalis, or to one of the sultivated species in which the white spots on the leaves are more pronounced than in our native species.

Virgin Mary's Nipple. Rev. Hilderic Friend, writes in his "Flowers and Flower Lore" :"During a recent visit to the West of England I found that the name of Virgin Mary's Nipple was ppied by the people in some parts of Somerset to a certain flant noted for the milk-white sap whish flows from it on being gathered. It is nt a little curious that this plant, which belongs to the Spurge family, should in some places be conse :ated to the devil ; but so it is." Mr. James Britten suggests that the particular plant referred to is probably the Sun Spurge, Euphorbia Helioscopia.

Virgar Mary's Tears. Common Lungwort, $P$ lmonaria officinalis (Weymouth). See MiArX's TEAPS.

VIRGIN's BowER. A general name for the Wild Clem is or Traveller's Joy, Clematis Vitalba.

VIRGIN's FINGERs. Correspondents at East Coker and Stockland (Devon) give me this as a local name for the Foxglove, Digitalis purpurea.

VIRGIN's MImK. Several school-children at Thorne St. Margaret give me tnis as a local name for the "IIilk Thistle," by which they probably mean the common Sow Thistle, Sonchus oleraceus.

Vlex. Flax (West Somerset).

VorET. A common mis-pronunciation of Vinlet.

VREX or VREXEN. Rushes, Juncus b'fonius (Weat Somerset). See REX-BUSH and REXEN. 
Vuz. Gorse ; Whin ; Furze, Olex europaus.

Vuzzen. A Dorset and East Somerset form of $\mathrm{Vuz}$.

WAG-A-W AMS (or WANDS). Quaking-grass, Briza media (East Somerset).

WAGGIN'-Grass. Quaking-grass, as above (Pulman).

WAG-W AFERS. Quaking-grass (Charmouth).

WAG-WAMS (WANDS, WANTS, Or WANTONS). Quaking-grass, Briza media.

WAG-WINDS. Quaking-grass (Muchelney).

W ATTE-WEED (i.e., Wet-rweed). The Dandelion, Taraxacum officinale (Donhead, Wilts). See WETABED.

Wake at Noon. The Star of Bethlehem, Ornithogalum umbellatum (North-W est Wilts).

WAKE RoBIN. An old name, still frequently used, for the Wild Arum or Cuckoo-pint, Arum maculatum.

WALKING-GRASS. An Ilminster school-girl gives me this as a local name for the Wild Oat, Avena fatua.

WALLET. Biushwood; bramble-wood (Rev. W. P. Williams).

WALL GINGER. Biting Stonecrop, Sedum acre; more often called WALI PEPPER.

WALL GRASs. Biting Stonecron, Sedum acre (Devon; Rev. H. Friend).

WaLl LIrAC. Red Spur Valerian, Kentranthus ruber (a school-boy at Axbridge).

W ALl PEPPER. Biting Stonecrop, Sedum acre.

WANDERING JACK. The Ivy-leaved Toad-flax, Linaria Cymbalaria (TWatchet). More often called WANDERING (or ROVING) SAILOR.

W ANDERING JEW. The old-fasbioned pot plant, Saxifraga sarmentosa. See AARON's BEARD (2).

WANDERING SATLOR. (1) The Ivy-leaved Toadflax, Linaria Cymbalaria.

(2) The name is also sometimes given in Devon to the Moneywort or "Creeuing Jenny," Lysimachia Nummularia.

WANDERING WHIIE. (1) School-children at Dunster, Brompton Regis, and Stockland (Devon) give this name to the Convolvulus-I do not know whether Greater or Lesser.

(2) Miss Parkin tells me that some of the school-children at Brompton Regis give this name to the Ierb Robert, Geranium Robertianum.

WARRIORS. Wallflowers, Cheiranthus Cheiri. SEe BLOODY WARRIORS. 
WART-CrEss. The general English name for Coronopus didymus; also used for the Swine's Cress, Coronopus procumbens.

Wart Curer (or PLANT). Greater Celandine, Chelidonium majus (West Somerset).

WART Flower. The Rev. H. Friend says "In Devonshire the Ranunculus is still called WARTFLower, on account of its milky juice being employed for painting those unsightly protuberances." Dr. Watson writes me: "There is no juice which can be called milky in Ranunculus. I expect that the Greater Celandine is the plant referred to. Its yellow juice, if regularly applied, cures warts. Confusion has perhaps arisen with the Lesser Celandine, and thence to other species of Ranunculus."

WART-WEED. The Sun Spurge, Euphorbia Helioscopia, from its juice being used to cure warts.

WART-WORT. (1) The Greater Celandine, Cheidonium majus, the juice of which is vsed to cure warts (Wilts).

(2) The Petty Spurge, Euphorbia Peplus (Wilt-).

Watch CHatNs (or W ATCH AND CHarns). The Laburnur, Laburmum vulgare; more often called Golden ChaIN.

WATCHES. (1) A number of schojl-girls at South Petherton give me this as a local name for a St. John's Wort, but do not indicate tbe species

(2) The Greater Celandine, Stellaria Holostea. (Stickland, Dorset).

Watches AND Clocks. The Dandelion: Taraxacum officinale (a Yeovil school-boy). Mrore, often called CLOCKS.

WATER ANEMone. The Iry-leafed Crowfoot, Ranunculus hederaceus (Zeals, Wilts). Dr. Watson tells me the name is used more particularly for the larger-flowered Water Crowfoots.

WATER Babies. The Marsh Marigolo, Caltha palustris (a IIrcheloey school-boj).

WATER Beetney (or Betony). Water Figwort, Scrophularic aquatica; a popular rem eey for inflammations.

WATER BIRD'S-EYe. Broo-lina, Veronica Beccabunga (Alington, Deron).

WATER BLoBs. (1) The Marsh Marigold Caltha palustris. See MAY BLoBs.

(2) The Yellow Water Lily, Nymphoea lutea (Wilts).

Water Bubbles. The Marsh Marigold, Caltha palustris (Bruton and Thorncombe).

WATER BUTTERCUP. (1) The Marsh Marigold Caltha palustris (Devon; Rev. H. Friend). 
(2) The Lesser Spearwort, Ranunoulus Flammula (Zeals, Wilts). lutea.

WATER CaN. The Yellow Water Lily, Nymphcea

Water Cuckoo. Lady's Smock or Cuckooflower, Cardamine pratensis (S.W. Wilts).

WATER CuPS. The Yellow Water Lily, Nymphcea lutea (Bridgwater).

WATER ELDER. The Guelder Rose, Viburnum Opulus.

Water Flag. The Yellow Iris, Iris Pseudacorus.

Water Forget-ME-Not. The Evergreen Allanet, Anchusa sempervirens (West Somerset). Dr. Watson writes me that this must be an error, as the Evergreen Alkanet is not a water plant, but several correspondents in West Somerset assure me the name is so used.

W ATER GEorgIES. The Marsh Marigold, Caltha palustris (Sexey's Sehool and Mells).

W ATER Grass. See Old Max's BeAPd (5).

WATER LeEk. Broad-leaved Garlic or Ramsons, Allium ursinum (Staple Fitzpaine).

WATER LILY. (1) The Yellow Iris, Iris Pseudacomis. It will be easy to account for the Iris being localiy alled a tily when we remember that this flower is generally supposed to be the lily of France, and that one of sur greatest writers speaks of

"Lilies of all kinds,

'The flower-de-luce being one.'

(2) The Marsh MIarigold, Caltha palustris; almost as commonly used as No. 1.

(3) The Water Crowfoot, Ranunculus aquatilis (Charlton, Wiits, and West Somerset).

Water Pepper. The Biting Persicaria, Polygonum Hydropiper.

Water Poplar. The Black Poplar, Populus nigra. The name is applied also to Populus fastigata.

WATER Rose. The White Water Lily, Castalia alba (North Petherton).

WATER SqUiRT. The Wild Angeliea, Angelica sylvestris (Shoseombe).

WAX Douls. Correspondents at Taunton, Chard, and Evershot send me this as a lccal name for the Common Fumitory, Fumaria officinalis.

Waxworks. Common Milkwort, Polygala vulgaris (Farley, Wilts).

WAYBREAD. An old English name for the Greater Plautain, Plantago major. 
Watfaring Tree. A general name for the Mealy Guelder-rose, Viburnum Lantana.

Wayside BeAutr. The Blasithorn, Prunus spinosa (a scho l-boy at Hardington Mandeville).

WAYSIDE Bread. The Greater Plantain, Plantago major (Wilts; Eng. Plant Names).

WEAsEL'S Nose. A variation of WEAEELsNOUT sent me from Kimmeridge, Dorset.

WEASEL-SNOUT. A gejeral English name for the Yellow Dead-nettle, Lamium Galeobdolon.

WEATHER Clocks. The Dandelion, Taraxacum officinale (school-boy at Long Sutton).

Weather FLowER. The Scarlet Pimpernel, Anagallis arvensis (Milborne Port).

Weather Teller. The Scarlet Pimpernel, as above (We-t Somerset).

Weather Guass. The Scarlet Pimpernel, as above (East Somerset and Wilts).

Wedding Flowers. Anemones (? Anemone nemorosa) (Camerton).

WEeping GoLden BecLs. A lady at Wells gives me this as a lozal name for a species of Forsythia - a genus of slender shrubs of the Olive family, natives of China and Japan, of which two species are cultivated in parks under the name of GoLDEN RAIN. Mr. T. W. Cowan suggests the particular species would probably be F. suspensa.

WEEPING WHLOW. In some parts of North Devon tbis name is given to the Laburnum, Laburnum vulgare, from its drooping clusters of golden blossoms, and its leaf being somewhat like that of the willow. The true Weeping Willow is Salix babylonica.

Wenps. Dr. R. C. Knight gives me this as an East Somerset word for long brushwood, bound into small bundles with three bonds (instead of one as an ordinary faggot), used for shelter, e.g. lambing yards, open cow-stalls, \&c. He tells me he has never heard it used in the singular.

WELCOME HOME, HUSBAND, THOUGH NEVER so DRUNK. This very curious local name for the Ycllow Stonecrop, Sedum acre, is sent me by a lady at Hammoon (Dorset).

WELD. A general English name for the Dyer's Rocket or Yellow Weed, Reseda Luteola: sometimes called Dyer's MrgNonetTE.

WeLsH NUT. The Walnut, Juglans regia.

WET-ABED (or WeT THE BED). The Dandelion, Taraxacum officinale. 
What (or What's) o'Clock. The Dandelion, Taraxacum officinale. See Clocks (1).

WHIP Top. The Mealy Guelder Rose or Wayfaring Tree, Viburnum Lantana (Rampisham, Dorset).

WHISkERS. The MIoschatel, Adoxa Moschatellina (many school-children at Paulton).

WHISKERS ON THE EARTH. Grass (schoolchildren at Thorne St. Margaret and Oare).

WhIT ALLER. A West Somerset name for the Elder, Sambucus nigra.

WHITE AND RED. Wild Arum or Cuckoopint, Arum maculatum (Leigh, Dorset).

White ANGel Orchid. Miss Ida Ropen tells me that this name is given in the Bristol district to the Great Butterfly Orchis, Habenaria chlorantha.

White Archangel. The White Dead-nettle, Lamium album.

White Ash. The Common Goutweed, Eggopodium Podagraria. See AsHWEed.

Whrte Belus. (1) The Snowdrop, Galanthus* nivalis (Paulton).

(2) Lily of the Valley, Convallaria majalis.

(3) Greater Stitchwort, Stellaria Holostea (Bathealton).

WhITE BETTY. "Snow on the Mouatain," Arabis alpina (Aller).

WHITE BLUEBELL. A white variety of the Wild Hyacinth or Bluebell, Scilla non-seripta.

White BotTles. A fairly general nama throughout the district for the Bladder Campion, Silene latifolia.

W HIтE Cock-robin. Bladder Campion, Silene latifolia (East Harptree).

W HITE CUPS. The Snowdrop, Galanthus nivalis (an Evercreech school-boy).

WHITE EASTER. "Snow on the Mountain" (?.Arabis alpina) (Chaffeombe).

WHITE-FLOWER. The Greater Stitchwort, Stellaria Holostea (Wilts).

WhITE-FLOWERED Grass. Mr. Edward Vivian (Trowbridge) gives me this as a local name for the Stitchwort, as above.

WHTTE FLOWER OF HELL. Miss FIla Ford, of Melplash, gives me this as a local name for the Bladder Campion, Silene latifolia, in consequence of the poison supposed to be contained in its leaves and "bladders." This, I think, must be entirely due to a misconception. The young leaves are frequently eaten by children, and are 
supposed to have a flavour of green peas; they have also been used as a substitute for Asparagus, and $I$ believe are quite harmless. Mir. F. Edward Hulme, in his "Familiar Wild Flowers," writes : - "The plant was once called the Cucubalus, a word derived from the Greek words, signif ying a bad or noxious growth. It is evident that the name, first employed by Pliny, has been diverted from the plant to which he applied it, and to which it may have been most appropriate, and has by some mediæval misconception been given to a plant altogether innoxious."

White Fruls. The Daisy, Bellis perennis (Camerton).

WHITEHEADS. Spikes of the Great Reed Mace or Bulrush, Typha latifolia, when the downy matter has ripened and lost the colour which gave them the name of Blackheads (D_von).

WHTTE HELL-FLOWER. See WhITE FLOWER OF HELL.

Wнाте HooD. Bladder Campion, Silene latifolia (Dunster).

WHITE LACEY. album (Odcombe).

(1) White Stonecrop, Sedum

(2) "Snow on the Mountain," Arabis alpina (a Yeovil school-b:y).

WHTTE LADY. The school-children at Hatch Beauchamp give me this as a local name for the Mallow, but it is not easy to see the reason.

Wнтте QuEEN. The Snowdrop, Galanthus nivalis (school-children at Otterhampton).

WhITE RIDING HooD. (1) The White (or Evening) Campion, Lychnis alba (Hembury, Devon).

(2) The Bladder Campion, Silene latifolia (Alfington, Devon).

WhIte RoBIN. The White Campion, Lychnis alba (Dorset).

WhITE RoBIN Hood. (1) The White Campion, Lychnis alba. (Zeals, Wilts).

WHTTE RocK. (1) Arabis alpina.

(2) Cerastium tomentosim. Both plants are more often called SNOW ON THE MIOUNTAIN or SNOW IN HARVEST.

WHTE Rocket. Common Rocket or Dame's Violet, Hesperis matronalis; common single white variety.

WhITE SHIRTS. Greater Convolvulus or HedgeBindweed, Calystegia sepium (Martock schoolboys). 


\section{5}

WHITE Surock. The Greater Convolvulus, Calystegia sepium (Membury, Devon).

IV HITE SMrock-FRock. The Columbine, Aquilegia vulgaris (Fivehead).

White SNAP-JACKS. The Sea Campion, Silene maritima (Ninehead). So called from the fact its " bladders " are frequently snapped by children on the backs of their hands, with a sharp noise.

Whtte Sting NetTíe. The White Deadnettle, Lamium album (Deron).

White (or Whit) Sundays. (1) The Rev. H. Firiend says: "In both North and South Devon this name is given to the Narcissus biflorus." Several school-children at Hawkehurch send me WHITE SUNDAYS as a local name for Narcissi.

(2) The Greater Stitchwort, Stellaria Holostea (Devon).

(3) Several school-children at Brompton Regis give me this as a local name for "Whitsuntide Balls" by which I imagine they mean the Guelder Rose.

WHTTESUN GLAWFERS. (1) The Double White Rocket, Double-flowering Hesperis matronalis (F. T. Elworthy).

(2) Other correspondents in West Somerset and elsewhere apply the name to the Stock, Matthiola.

White Watch and Chatn. The Acacia (school-children at Ilminster).

White WeEd (or Wood). The Mealy Guelder Rose, Viburnum Lantana (Wilts).

WHTSUN BaLls. (1) The Guelder Rose, Viburnum Opulus.

(2) The Red Peony, Pconia officinalis (Stockland Bristol).

Whit Sunday. See White Sunday.

WHTTSUN FLOWER. (1) The Guelder Rose, Viburnum Opulus (North Petherton).

(2) The Wood-sorrel, Oxalis Acetosella (Dors).

WHITSUN GLAFFER, GILAWFER, or GIIOFFER. (1) A number of correspondents in West Somerset and other parts of the county give me this as a local name for the Bromoton Stock, Matthiola incana.

(2) The Rev. W. P. Williams gives it as a Somersetshire name for Carnations, Dianthus Caryophyllus, and also

(3) Wallflowers, Cheiranthus Cheiri.

WHITSUN GILLY-FLOWER. A Bridgwater correspondent gives me this as a local name for White Ro:ket, Hesperis matronalis.

WHTrsun Rose. The Guelder Rose, Diburnum Opulus (Axbridge). 
Whitsun TASSELS. The Guelder Rose, as above (Bradford-on-Tone). See MAY TAssels.

WHITSUNTIDE. The Lilac, Syringa vulgaris (Mr. F. W. Mathervs, Bradford-on-Tone).

Whitsuntide Bosses. The Guelder Rose, Viburnum Opulus (Thorncombe and Charmouth). Applied in some districts to the garden variety only.

Whitsuntide GILLy (or Jelly) Flower. (1). A correspondent at Broadstone gives me this as a local name for the Sweet Rocket, Hesperis matronalis.

(2) The Rev. H. N. Ellacombe, vicar of Bitton in 1870, writing of the Pink, said it is not so named for its colour ; it comes by an easy and well-ascertained course from "Pentecost," and is in fact the WHITSUNTIDE GILLY-FLOWER of our ancestors.

W HITTY-TREE. The Mealy Guelder-rose, Viburnum Lantana (S.W. Wilts).

Wно Stole the Donkey? The Goose-grass or Cleavers, Galium Aparine (North Somerset).

WICked Tree. The Lesser Dodder, Cuscuta Epithymum (Miss Ella Ford, Melplash).

WiCken Tree. The Mountain Ash, Pyrus Aucuparia (Compton, near Yeovil). Dr. Watson tells me that WICKEN-BERRY is a common name in some parts of the Pennines.

WIDow's CAP. The Calceolaria (Bruton).

Wroow's WeEds. The Columbine, Aquilegia vulgaris (T⿺辶wbridge).

WID-WIND (Chewt on Mendip) and

WIDDY WINe (Chilton Polden). See WithrWIND.

WIGGER-WAGGERS. Quaking Grass, Briza media (Bradford-on-Tone).

W IGGLE WAGGLES. Quaking Grass, as above (East Somerset, and Bradford--on-Tone).

WIGGLE WANTOMS. Quaking Grass (Chewton Mendip).

WigGLE WANTS. Quaking Grass (S.W. Wilts). Wiggle Woggles. Quaking Grass (Dorset).

WIGGY WANTONS. Quaking Grass (Chewton Mendip).

W IG WAMrs. A common name for the Quaking Gicass, Briza media, over the Eastern half of Somerset and parts of Dorset and Wilts.

W IG WANDs. Quaking Grass, as above (Dors at).

WILD Asparagus. Spiked Star of Bethlehem, Ornithogalum pyrenaicum (Somerset and S.W. Wilts). See Bath Asparagus. 
WILD Aster. The Field Scabious, Scabiosa arvensis (Ubley).

WILD BULls' Eyes. Mr. W. C. Baker, late of Maunsel, gives me this as a local name for a species of St. John's Wort, Hypericum.

WiLd Bunny RABBITs. Yellow Toadflax, Linaria vulgaris (Stalbridge).

WmD CABbage. (1) The Sea Cabbage, Brassica oleracea; very rare in Somerset, but abundant on the banks of the Yeo between Ilchester and MIudford, where it can only be considered as an escape from cultivation (Rev. R. P. Murray).

(2) The Schoolmaster at Batcombe gives me this as a local name for the Yellow Rocket, but I fancy there must be some confusion here.

WHD CATCEOLARIA. A young lady at Wellington gives me this as a local name for the Bird'sfoot Trefoil, Lotus corniculatus.

Wild Christiras Rose. The Green Hellebore, Helleborus viridis.

WIID ChRYSANTHEMUM. Ragwort, Senecio Jacobaea (Alfington, Devon).

Wild CoRNFLotrer. (1) The Corn Bluebottle, Centaurea Cyanus.

(2) The Greater Knapweed Centaurea Scabiosa.

(3) The Black Knapweed, Centaurea nigra.

WILD Crocus. The Meadow Safiron, Colchicum autumnale; more often called AUTUMN CROCUS.

WiLd Fonget-ME-Not. (1) The Field Scorpion-grass, Myosotis arvensis. Other species of MIyosotis are called Forget-me-not but the prefix "Wild" appears to be limited to this particular plant.

(2) Mrs. H. Day gives me this as a North Petherton name for the Woodruff. Asperula odorata.

WILD GapMOUTH. The Yellow Toadflax, Linaria vulgaris (Bradford-on-Tone).

Wild Geranium. (1) The Herb Robert, Geranium Robertianum.

Fitzpaine).

(2) Common Mallow, Malva sylvestris (Staple

(3) A dozen school-children at Paulton give me this as a local name for the Ivy-leaved Toadflax, Linaria Cymbalaria. This, of course, is a mistake-I cannot say how wide-spread it may be in that district-but it would probably be traceable to a single source.

WILn Golden Chars. Yellow Melilot, Melilotus altissima (Shoscombe).

WILD Hops. A school-girl at Stogursey gives 
me this as a local name for the Meadow-sweet, Spircea Ulmaria. There appears to be some confusion here.

WILD HYACINTH. (1) This name rightly belongs to the Bluebell, Scilla non-scripta, but a number of correspondents in South and West Somerset and in Devon apply it to

(2) The Early Purple Orchis, Orchis mascula.

WII.D LILY. Common Arum or Cuckoo-pint, Arum maculatum (Devon).

WILD LIQUORICE. (1) The Rest-harrow, Ononis repens.

(2) Tho Sweet Milk-vetch, Astragalus glycyphyllos (White's Bristol Flora).

Wild Lobelia. Common Milkwort, Polygala vulgaris (Puddletown).

WILD LONDON PRIDE. (1) Mr. F. W. Mathews, of Bradford-on-Tone, gives me this as a local nams for the Enchanter's Nightshade, Circcea lutetiana.

(2) The Wood Sanicle, Sanicula europcea (Staple Fitzpaine).

WILD OnIons. Broad-lea ved Ga:lic, Allium ursinum.

WILD PhLox. The Willow-herb, Epilobium (Wellington).

Wild Potato Flower. The Woody Nightshade or Bittersiveet, Solanum Dulcamara. Dr. Watson adds: "And probably is much more likely to be applied to the Black Nightshade, S. nigrum.

WILd Purses. Shepherd's Purse, Capsella $B$ ursa pastoris (Camerton).

Wild Rhubarb. (1) The Burdock, Arctium.

(2) The Butter-bur, Petasites ovatus.

(3) The Colt's-fost, I'ussilago Farfara (Watchet).

WILD Rosemary. (1) An old name for the Lady's Bed-straw, Galium verum.

(2) The Marsh Andromeda, Andromeda polifolia (White's Bristol Flora).

Wild Shamrock. (1) The Wood Sorrel, Oxalis Acetosella.

(2) The Tuberous Moschatel, Adoxa Moschatellina (Watchet).

(3) Black Mredick or Nonsuch, Medicogo lupulina (school-children at Thorne St. MIargar:t).

Wild SNapdragon. (1) Yellow Toadflax, Linaria vulgaris.

(2) Also, and more properly, to the Weaselsnout, Antirrhinum Orontium (Dr. Watson).

WILd SpINACH. Mercury Goosefost or Good King Henry, Chenopodium Bonus-Henricus (White's Bristol Flora). 
WILD SweET PEA. (1) This name appears to be given to several different species of Vetch; many correspondents do not indisate any particular species, but others name the Tufted Vetch, Vicia Cracca, the Bush Vetch, $V$. sepium, the Common Vetch, V. sativa. Miss Roper adds the Narrow-leaved Everlasting Pea, Lathyrus sylvestris.

(2) The Rest-harrow, Ononis repens.

Wrid TANsy. The Silverweed, Potentilla Anserina.

WIID THYME. Bird's-foot Trefoil, Lotus corniculatus (Wells, Rev. R. P. Murray).

WIID Tовассо. (1). The Burdock, Arctium (Bradford-on-Tone).

(2) Plantain, Plantago (Yeovil school-boys).

WILD Tomato. (1) Mr. F. W. Mathews (Bradford-on-Tone) tells me that the common Nightshade, Solanum nigrum, is sometimes known by this name.

(2) A correspondent at Wimborne gives it as a local name for the Deadly Nightshade, Atropa Belladonna. This is probably a mistake due to contusion with the Woody Nightshade or Bittersweet, Solanum Dulcamara.

WIID VINE. The White (or Red-berried) Bryony, Bryonia dioica.

WIID Wrutran. A school-girl at Oake gives me this as a local name for the Dandelion, Taraxacum officinale. Mr. T. W. Cowan tells me that in some parts of England it is an old name for the Ragged Robin, Lychnis Flos-cuculi.

WIud Wruow. The Great Hairy Willow herb, Epilobium hirsutum (Wilts: Great Estate, chap. 2).

WILLIAM AND MARY. The Virginian Stock, Malcolmia maritima (school-girls at Ilminster).

Wruow Blossom. The Rev. H. Friend gives this as a Devonshire name for the Phlox, and suggests that it i. possibly due to some confusion with the Willow-herb. See WпD Pнцох.

Wriow-HERB. This is the general English name for the genus Epilobium, but it is sometimes applied to the Great Yellow Loosestrife, Lysimachia vulgaris, and several correspondents send me the name in this connection. Nir. W. S. Price tells me it is generally given to this plant in the Wellington district.

Writow-sTrIfe. The Purple Loosestrife, Lythrum Salicaria (Dunster and Compton, near Yeovil).

Wrumow-Worr. Mrs. H. Day gives me this as a North Petherton name for the Yellow Loosestrife, Lysimachia vulgaris. 
WIITSHIRE WEED. The common Elm, Ulmus campestris. The compilers of the Wiltshire Glossary say: "This is a term frequently occurring in books and articles on Wilts, but it would not be understood by the ordinary Wiltshire folk." See ElwM.

WIM-W AMs. The Quaking-grass, Briza media (Axbridge schosl-children).

WIND FLower. A very common name for the Wood Anemone, Anemone nemorosa. The name Anemone is derived from the Greek anemos-the wind, because the plant is said to love the wind.

WIND-Grass. Apera (White's Bristol Flora).

WIND-Mruss. The Blue Iris (school-children at Oakhill).

Wine GLasses. Canterbury Bells, Campanula medium (Bor sughbridge).

WIND-PIPE. A correspondent at Compton, near Yeovil, gives me this cririous name for the Scarlet Pimpernel, Anagallis arvensis. It may possibly be a corruption of WINK-A-PEEP or WINK-AND-PEEP given by Britten \& Holland as a country name for this plant, from the way in which its flowers close or wink on damp days, and open or peep again when the weather becomes fine.

WINGs. (1) The winged seeds of the Sycamore, Acer Pseudo-platanus ('Wellington).

(2) The winged seeds of the Ash, Fraxinus excelsior (Chewton Mendip).

WING-WoNgs. Quaking-grass, Briza media (North Curry, Stoke St. Gregory, and Wilts).

WINTER DAIsY and WINTER GERANIUM. The Rev. H. Friend says :- "In Somerset a small Chrysanthemum is called Winter Daisy, while the large varieties are known as Winter Geraniums."

WINTER GILLY-FLOWER. The Wall-flower, Cheiranthus Cheiri.

Winter Greens. Curled Kale, Brassica fimbricata (E. T. Elworthy).

WINTER-PICK. His Honour J. S. Udal gives this as a Dorset name for a large kind of Sloe.

Wrnter Rose. (1) The Hellebore (Devon).

(2) The Peony (Miss Ella Ford, Melplash).

Winter StratrberRy. The Strawberry tree, Arbutus Unedo.

Wirral (Worral or Wurral). Black Horehound, Ballota nigra. (S.W. Wilts, Somerset border).

WisHes. A correspondent at Chilmark (Wilts) gives me this as a local name for the Dandelion, Taraxacum officinale. 
WrTches' ARMs. The Common Hemp-nettle, Galeopsis Tetrahit (Miss Ella Eord, Melplash).

Witches' CAP. The Sunflower, Helianthus annuus (a school-girl at Smallridge, Axminster).

Witches' Gowan. Cultivated species of the Globe-flower, Trollius.

Witches' ThImrie. (1) The Harebell, Campanula rotundifolia.

(2) A Taunton lady applies the name to the Ivy-leaved Bell-flower, Wahlenbergia hederacea.

WITch Frower. (1) The Woody Nightshade, Solanum Dulcamara (Shoscombe).

(2) The Enchanter's Nightshade, Circcea lutetiana (Shoscombe).

WrTch HaLSE. The Wych Elm, Ulmus glabra (West Somerset).

WITCH Tree. The Wych Elm, as above.

WiTHERs. A coarse grass growing in marshy places; commonly called Sword-grass, because the biares are broad and sharp, Glyceria aquatica.

WITH-VINE (WIND or WINE). (1) The Field Convolvulus or Bindweed, Convolvulus arvensis.

(2) Less frequently the Hedge Convolvulus, Calystegia sepium.

(3) Couch-grass, Agropyron repens.

WrTHY. The Willow or Osier, Salix. All species are known by this name.

WITHY-BIND. Field Convolvulus or Bindweed, Convolvulus arvensis (Evershot).

WITHY-WEED. Field Convolvulus, as above (Ilminster and Horton).

WITHY-VINE (WIND or WINE). (1) The commonest nam 3 for the Field Convolvulus or Bindweed, Convolvulus arvensis. Mr. F. T. Elworthy says this name for the troublesome weed has remained unchanged for a thousand years.

(2) Mr. Edward Vivian tells me that in the Trowbridge district this name is also applied to the Wild Clematis, Clematis Vitalba. Dr. R. C. Knight tells me he has.heald the name so used at Castle Cary.

WTTHY-WINNY (or WINY). The Common (or Black) Bryony, Tamus communis (school-girls at Stockland, Devon).

WOAD WAX (or WAXEN). Dyer's Green-weed or Dyer's Wnin, Genista tinctoria.

WoLd MaN's BEARD. A Dorset form of OLD MAN's BEARD, which see.

Wolewort. A Wincanton school-girl gives me this as a local name for the Lesser Willowherb, Epilobium parviflorum. 
Worf's-BANe. The Monk's-hood, Aconitum Napellus.

WoLF's Ere. A school-girl at Evershot sends me this as a local name for the Small Bugloss, Lycopsis arvensis. Anne Pratt says the Dutch call this plant Wolfs-chyn, and this, as well as the scientific name, has a reference to the fancied resemblance of this flower to the face or eye of a wolf ; but he must have had a very active fancy to whose mind the resemblance was first suggested.

Woman's Night-cap. The Wood Sorrel, Oxalis Acetosella (a school-girl at Brompton Regis).

Wood ALONE. The Moschatel, Adoxa Moschatellina (Miss Ella Ford, Melplash).

Woon AsH. The Wood Sorrel, Oxalis Acetosella (a school-girl at Chewton Mendip).

Wood Elder. Dr. R. C. Knight gives me this as a Somerset name for the Wood Sanicle, Sanicula europcea.

Wood Laures. The Common Spurge Laurel, Daphne Laureola.

Wood Pea. The Tuberous Bitter Vetch, Lathyrus montanus.

Wood Wax. (1) Dyer's Greenweed, Genista tinctoria (Wilts and Dorset). Wilts).

(2) Needle Whin, Genista anglica (Farley,

(3) The Broom, Cytisus scoparius (schoolgirls at $\mathbf{S}$ ock and, Devon).

Wood Wex. A Dorset form of Wood-WAX (1).

Woolly Heads. The Wool Anenome, Anenome nemorosa (Dowish Wak).

WoRd (or WOARD) APPles (i.e., hoard apples). Mr. F. W. Mathews, of Bradford-on-Tone, gives me this as a local term ap ried to dessert fruit as as distinguish d from cider fruit, th latter being used fresh and juisy, but the former being stored or hoarded to mature and mellew.

WORM-SEED. The Worm-seed Treacle-mustard, Erysimum cheiranthoides. The name owes its origin to the seeds of the plant being used as a vermifuge.

Wormwood. (1) The true Wormwood is Artemesia Absinthium, but through confusion the name is sometimes applied to the Mugwort, $A$. vulgaris, and also to the Southernwood oc Boy's Love, A. abrotonum.

(2) The Nipplewort, Lapsana communis (Watchet).

WorTs. The Whortleberry, Vaccinium Myrtillus; more particularly applied to the fruit. 
Woundwort. (1) This is the general English name for plants of the genus Stachys.

(2) A lady at Martock gives me this as a local name for the Common Yorrow, Achillea Millefolium, which was formerly used as a vulnerary. One of its old English names was Souldier's Wound-wort, and one of its present popular names is Nose-bleed.

(3) Several correspondents apply the name to the Common Golden-rod, Solidago Virgaurea; formerly greatly esteemed as "a soveraigne wound-herb, inferior to none, both for inward and outward hurts."

Wren Flower. The Horb Robert, Geranium Robertianum. See JenNy WREN.

WuK. A Somerset pronounciation of Oak.

WUTs. A Somerset pronounciation of Oats.

YaluERs. The Ragwort, Senecio Jacobcea (Brean).

YAP-MOUTH. A Taunton correspondent gives me this as a local name for the Snapdragon, Antirrhinum majus.

Yard DaIstes. The Feverfer, Chrysanthemum Parthenium (Queen Camel). Dr. Watson writes : - "Much moro likely to be applied to Matricaria Chamomilla, or M. inodora, ir Anthemis Cotula. These daisy-like plants are mor. commonly found in yards tnan the Feverfew."

YelLOW BeLls. The Daffodil, Narcissus Pseudo-Narcissus (Paulton school-children).

Yeluow Butrons. (1) The Common Tansy, Tanacet im $v$ igare.

(2) Buttercup;, Ranunculus (Camerton).

Yellow Clover. Hop Trefoil, Trifolium procumbens.

YELLOW CUPS. Buttercups in general (Zeals, Wilts).

Yelatow DeviLs. One of my Somerset correspondents sent me this as a local name for the Yellow Iris, Iris Pseudacorus, but I unfortunately omitted to make a note of the particular part of the county from which it came.

YeLLOW HEADs. Common Groundsel, Senecio vulgaris (a school-girl at Chewton Mendip).

Yeluow HoLly. Mr. F. W. Mathews, of Bradford-on-Tone, gives me this as a name sometimes applied in that distriet to the Barberry, Berberis vilgaris, from the colour of the flower anid the prickliness of the leaves. Several correspondents point out that the leaves of the Common Barberry ara not prickly. Niiss Roper suggests the species referred to may be $B$. aquifolium, which is often planted as cover for pheasa.ats. 
Mr. Britten suggests Mahonia, which I believe is another name for the species mentioned by Miss Roper.

Yeluow LAdies. The double form of the Daffodil, Narcissus Pseudo-Narcissus (Muchelney)

Yellow MaIdens. The Daffodil (Ilminster school-girls).

YeLLOW OX-Exe. The Corn Marigold, Chrysanthemum segetim.

YelLow PntPernel. A general English name for the Wood Loosestrife, Lysimachia nemorum.

Yeluow Prince. Yellow Wallflowers, Cheiranthus Cheiri (Axbridge school-children).

YelLow Rocket. Common Winter-cress, Barbarea vulgaris.

Yeliow Rose. The Japanese shrub, Kerria (or Corchorus) japonica.

YELLOW STARS. The Colt's-foot, Tussilago Farfara (Aller).

Yeltow Stratwberry. Common Avens or Herb Bennet, Geum urbanum (Ditcheat).

YeLLOW THATCH. Meadow Vetchling, Lathyrus pratensis (Zeals, Wilts).

Yeluow Trumpets. The Daffodil, Narcissus Pseudo-Narcissus (Hatch Beauchamp and Paulton school-shildren).

YeLLOW WATER LILY. This is, of course, the usual English name for Nymphcea lutea, but Mrs. H. Day tells me that in the North Petherton district the name is frequently applied (in error) to the Marsh Marigold, Caltha palustris, and Miss Roper tells me the name is so used i: the Chew Magna district also.

YELLOW WEED. A general English name for the Dyer's Rocket, Reseda Luteola.

Yeo Brmmle. See Yoe Brtmble.

YES OR No. The Rye-grass, or Eaver, Lolium perenne (South Petherton school-girls). See Does My Mother WANT Me? Love Me, Love ME Not, and TINKER TAILOR GRASS.

YETH. Very nommonly used in West Somerset and in parts of the Quantock country for various kinds of Heath and Heather.

Yew Brtm'Le. G. P. R. Pulman gives this as a local name for the Dog Rose, Rosa canina, in the Crewkerne and Axminster district. See YoE BRINBLE.

Yoe Brimble. The Common Bramble, Rubus fruticosus. MIr. F. T. Elworthy says: "The term is specially applied to one of the long rank rope-like runners which are so obstrustive to the beaters in a covert, and which are much sought after by broom squires for binds or tyers." 
YoRKSHIRE FoG. Soft Meadow-grass, Holcus lanatus.

Young MIAN's ButTon. The cultivated double variety of the Daisy, Bellis perennis (Closworth).

ZANIGUSETS. A school-girl at Nettlecombe (correct in a number of other names) gives me this as a local name for the Bladder Campion, Silene latifolia. At Kilton (not many miles distant) the name SAmary Gussets is given to the Early Purple Orchis.

ZENVY. Wild Mustard or Charlosk, Brassica arvensis. It was formerly known as Sinapis arvensis, and is said to take its local name of Zenvy from Sénevé, a French derivative of the Græco-Latin sinapi.

ZEPHYR Flower. The Wood Anemone, Anemone nemorosa. See WIND-Flower.

ZIG-ZAG. (1) The Zig-zag Clover, Trifolium medium.

(2) A lady at Stocl land Bristol gives me this as a local name for the Maple (Acer campestris) and Sycamore (A. Pseudo-platanus).

ZiLgreen or Zingreen. The House-leek, Sempervivum tectorum. See SeLGReEN.

ZINEGAr. The Stock, Matthiola incana. See SINNEGAR.

Zinvy. See ZENvY.

ZoG. A Stink-horn; a very bad-smelling fungus, Phallus impudicus.

ZULU Flower. As a boy at Castle Cary I often heard the Field Wood-rush, Inzula campestris, called by this name, which I assumed to be a corruption of luzula.

In bringing to a close this list of Popular Names of Flowers, \&c., which has been appearing in this paper every week for the past 18 months, I wish once more to express my indebtedness to the hundreds of the helpers, both old and young, without whose assistance this collection of names could never have been compiled. It is literally true to say that several hundred readers of the four papers owned by the proprietors of the Herald, and also several hundred boys and girls in the schools of Somerset and the bordering counties, have each contributed a longe $e^{\circ}$ shorter list of names; and my share of the work has been simply to arrange these many names in alphabetical order and to note the districts from which they have come. From the first I fully realised the handicaps under which I should be working in attempting to compile a list of this kind with my very limited knowledge of the subject, and before venturing upon 
publication I determined to secure, if possible, the interest and help of a few of the best botanists I knew, and of experts in this branch of folk-speech. The response was most encouraging; I received ready promises of help from everyone whom I approached, and I am more than grateful for the generous way in which those promises have been fulfilled. I feel particularly indebted to the following ladies and gentlemen for the kind and valuable help they have been good enough to give me in the final preparation of the list for publication :-

Mr. James Britten, K.C.S.G., F.L.S., Brentford, Editor of "The Journal of Botany," and Joint Compiler with Mr. R. Holland of the "Dictionary of English Plant Names."

Mr. T. W. Cowan, F.L.S., F.G.S., F.R.M.S., D.Sc., Ph.D., Clevedon.

Dr. Harold Downes, F.L.S., F.G.S., F.R.M.S., Ilminster.

Dr. R. C. Kright, D.Sc., D.I.C., Imperial College, South Kensington,

Mr. W. D. Miller, Cheddos, Taunton.

Mr. C. T. Onions, Old Ashmolean, Oxford, one of the Edit:rs of the "Oxford English Dictionary."

Miss Ida M. Roper, F.L.S., Bristol.

Dr. W. Watson, D.sc., A.L.S., Tauaton School.

I am also grateful to Miss M. J. Shute (late of Oare), Mr. F. W. Mathews (Bradford-on-Tone), and Mr. W. S. Price (Wellington) for a considerable amount of help in this direction, particularly in connection with names used in their own districts.

All these have done me the favour of going carefully through advance proofs of my list as I have put it into type, and they have not only made many useful and interesting additions to it, but they have also corrected many errors which, but for their kind services, I should either have made or allowed to pass undetected.

I wish to make it quite clear that those who have kindly helped me in this direction must not be considered in any way responsible for any faults which may be found in the list as I have printed it. Most of them have been good enough on more than one occasion to make valuable suggestions which I have not seen my way to adopt, and some of then have criticised quite frankly both my method of arrangement and the inclusion of some of the names, particularly of those which I have inserted as coming only from a scrool-boy or school-girl in some village. In this matter I have followed throughsut the policy which I laid down in my preface, 
in which I tried to make it clear that in thus printing the names which it had been my privilege to collect, I was merely offering a contribution towards a more worthy glossary for our county, which I hope may some day be compiled by an abler man, who will probably find no difficulty in deciding how many of these names may be worth preserving. In the meantime, everyone into whose hands a copy of my list happens to come must decide for himself the value which he will place upon names which I have allowed to appear, upon what he may consider doubtful authority.

My original intention was to follow this glossary with an index, in which all the scientific names of the plants mentioned would be arranged in alphabetical order, and under each would be given the whole of the local names for that particular plant which had appeared in the glossar $J$. I am afraid this idea must be abandoned. The list of names has already extended over many more months than I anticipated, and such an index as I contemplated would occupy a column of this paper every week for many months yet to come. I cannot believe tbat it would be of sufficient interest or value to justify the large amount of time, money, and space which would be necessary to compile ana print it. One of the chief purposes of such an index has to a great extent already been met by the many cross references which have been given all tha way through the glossary.

A. S. macmilian. 





\section{QK13.M32 York Botanical Garden Library Macmilian, Alexande/Popular names of flo 35185000961852}




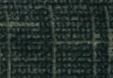

6.

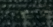

(1)

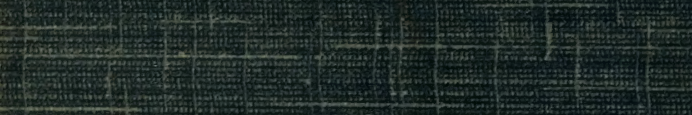

